
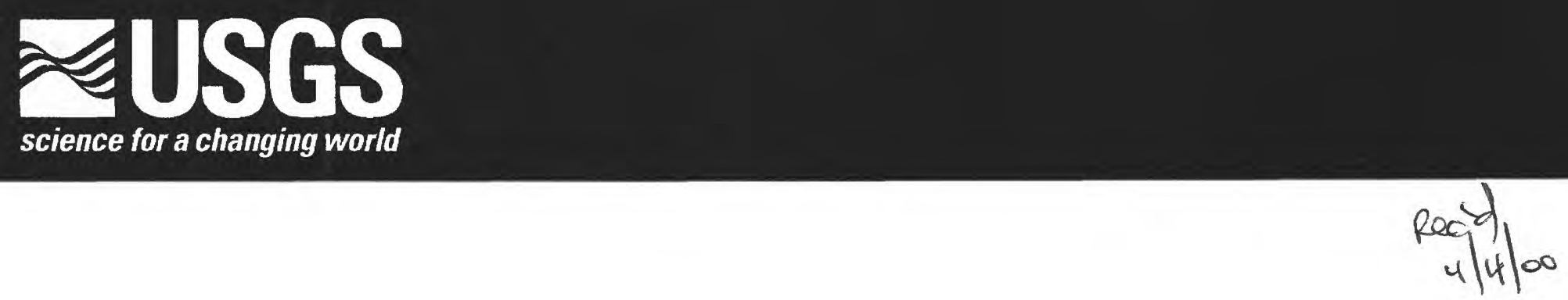

In cooperation with the

RAVALLI COUNTY BOARD OF COMMISSIONERS and the BITTERROOT CONSERVATION DISTRICT

\title{
Hydrogeology and Aquifer Sensitivity of the Bitterroot Valley, Ravalli County, Montana
}

Water-Resources Investigations Report 99-4219 
U.S. Department of the Interior

U.S. Geological Survey

Hydrogeology and Aquifer Sensitivity of the Bitterroot Valley, Ravalli County, Montana

By David W. Briar and DeAnn M. Dutton

Water-Resources Investigations Report 99-4219

In cooperation with the RAVALLI COUNTY BOARD OF COMMISSIONERS and the BITTERROOT CONSERVATION DISTRICT 


\section{U.S. Department of the Interior \\ BRUCE BABBITT, Secretary}

\section{U.S. Geological Survey}

Charles G. Groat, Director

Any use of trade, product, or firm name in this publication is for descriptive purposes only and does not imply endorsement by the U.S. Government

Helena, Montana

February 2000

For additional information write to:

\section{District Chief}

U.S. Geological Survey

3162 Bozeman Avenue

Helena, MT 59601-6456

Copies of this report may be purchased from:

U.S. Geological Survey

Branch of Information Services

Box 25286

Denver, CO 80225-0286 


\section{CONTENTS}

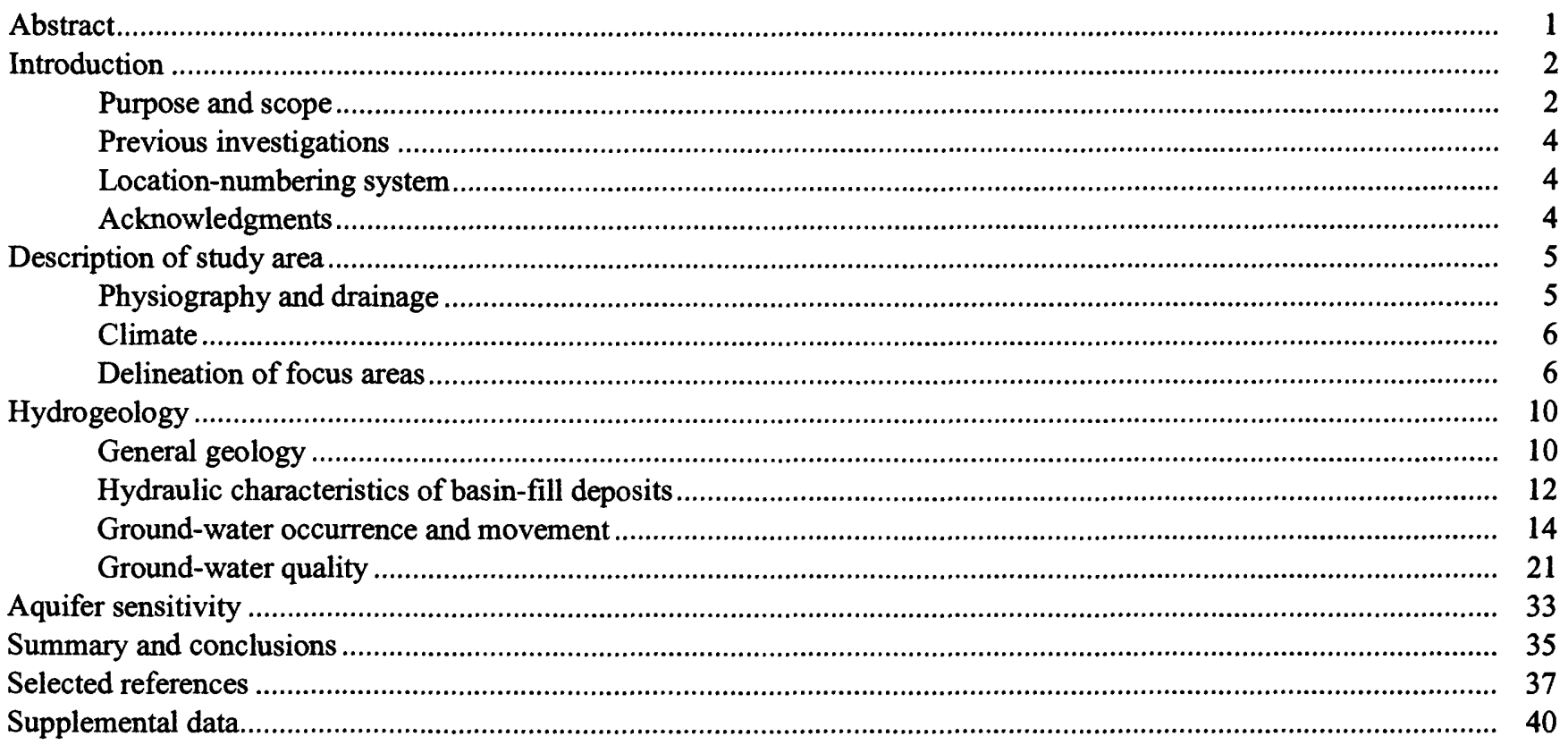

\section{ILLUSTRATIONS}

Figure 1. Map showing location of study area within the Bitterroot River drainage basin, Ravalli County, Montana ... 3

2. Diagram showing location-numbering system........................................................................................ 5

3. Map showing average annual precipitation in Ravalli County ............................................................. 7

4. Graph showing monthly precipitation for the study period and the mean monthly precipitation for the 1961-90 period of record at Hamilton, Montana...

5. Map showing locations of focus areas, inventoried wells, and surface-water sites, and corresponding availability of water-quality analyses .....

6. Map showing generalized surficial geology in the study area .....

7. Boxplots showing range of static-water levels, yields, and specific capacities of wells based on geologic unit and location.

8-10. Maps showing altitude of the water-level surface and location of monitoring wells in the:

8. Eightmile area, 1995 .

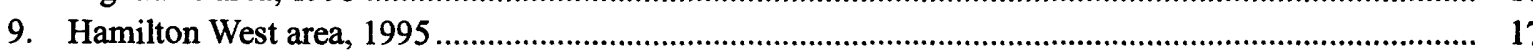

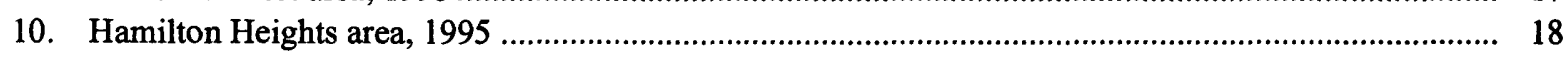

11. Map showing location of sediments, focus areas, and drainage areas upgradient from sediment and focus areas.....

12. Boxplots showing specific conductance in well water grouped by location and geologic unit...................... 22

13. Boxplots showing nitrate concentration in well water grouped by location and geologic unit ....................... 24

14. Graph showing nitrate concentration in well water versus depth to top of well casing open interval.............. 25

15-17. Maps showing distribution of nitrate concentration in well water from the:

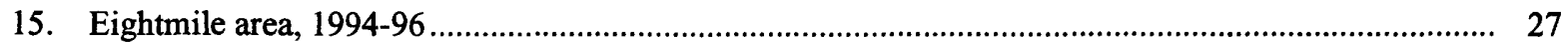

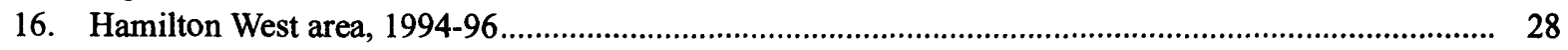

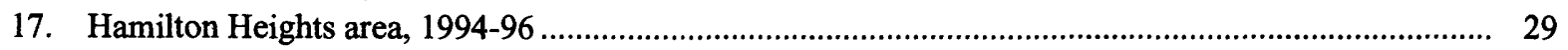

18. Graphs showing monthly variation in nitrate concentration in well water ................................................ 30

19. Modified trilinear diagram showing percentages of major ions in well water from the three focus areas ....... 31

20. Graph showing population of Ravalli County by year, 1970-97 ........................................................ 34

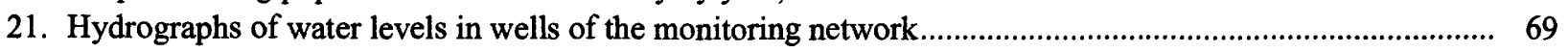




\section{TABLES}

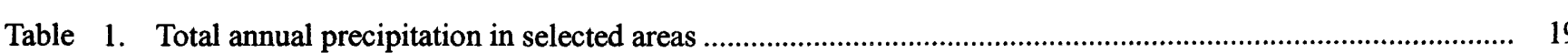

2. Location and description of surface-water sites and one spring ........................................................... 32

3. Summary of specific conductance, nitrate concentration, well density, average precipitation, and percentage of wells completed in Tertiary alluvial-fan deposits in the three focus areas.............................. 35

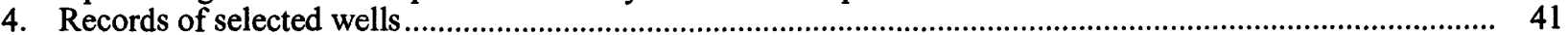

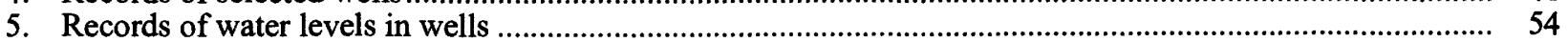

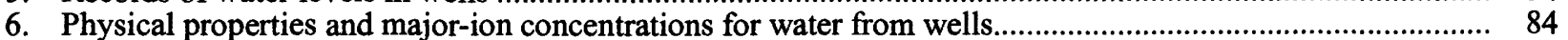

7. Trace-element and radon concentrations for water from wells .................................................................... 106

8. Physical properties and major-ion concentrations for water from surface-water sites and one spring............... 110

9. Trace-element concentrations for water from surface-water sites ............................................................ 111

10. Physical properties and major-ion concentrations for deionized-water field blanks .................................... 112

11. Trace-element concentrations for deionized-water field blanks ................................................................. 113

12. Drinking-water regulations and guidelines for public water supply ....................................................... 114

\section{CONVERSION FACTORS, VERTICAL DATUM, AND ABBREVIATED WATER-QUALITY UNITS}

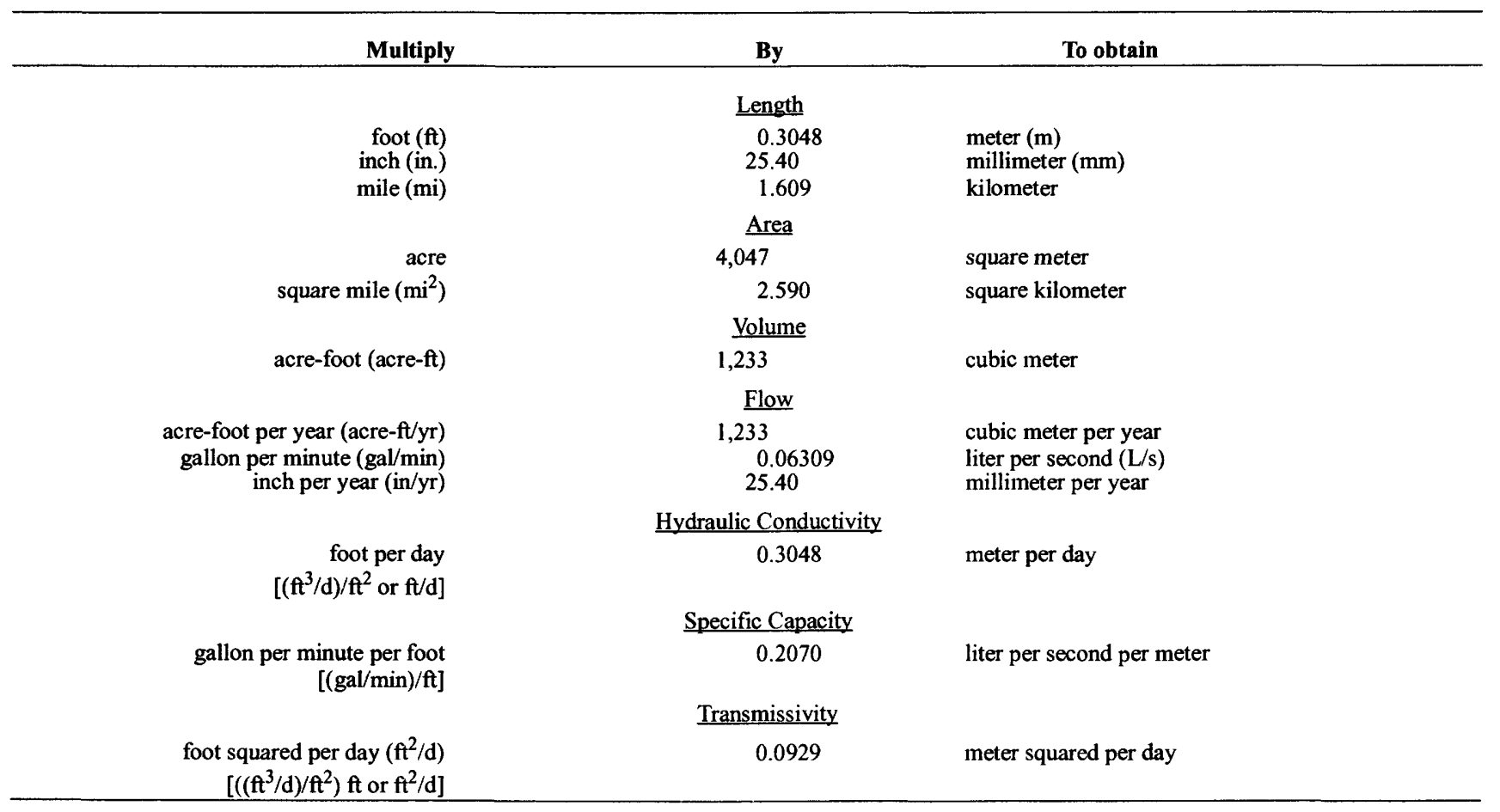

Temperature can be converted to degrees Celsius $\left({ }^{\circ} \mathrm{C}\right)$ or degrees Fahrenheit $\left({ }^{\circ} \mathrm{F}\right)$ by the equations:

$$
\begin{aligned}
{ }^{\circ} \mathrm{C} & =5 / 9\left({ }^{\circ} \mathrm{F}-32\right) \\
{ }^{\circ} \mathrm{F} & =9 / 5\left({ }^{\circ} \mathrm{C}\right)+32
\end{aligned}
$$

Sea level: In this report, "sea level" refers to the National Geodetic Vertical Datum of 1929 (NGVD of 1929)--a geodetic datum derived from a general adjustment of the first-order level nets of both the United States and Canada, formerly called Sea Level Datum of 1929.

Abbreviated water-quality units used in this report:

$\mu \mathrm{g} / \mathrm{L} \quad$ micrograms per liter

$\mu \mathrm{S} / \mathrm{cm} \quad$ microsiemens per centimeter at $25^{\circ} \mathrm{C}$

$\mathrm{mg} / \mathrm{L} \quad$ milligrams per liter

$\mathrm{pCi} / \mathrm{L}$ picocuries per liter
Acronyms used in this report:

GIS Geographic Information System

GWIC Montana Ground Water Information Center

MBMG Montana Bureau of Mines and Geology

MCL Maximum Contaminant Level

NWQL USGS National Water Quality Laboratory

SMCL Secondary Maximum Contaminant Level

UM University of Montana

USGS U.S. Geological Survey 


\title{
HYDROGEOLOGY AND AQUIFER SENSITIVITY OF THE BITTERROOT VALLEY, RAVALLI COUNTY, MONTANA
}

\author{
By David W. Briar and DeAnn M. Dutton
}

\section{Abstract}

The population of the Bitterroot Valley in western Montana increased rapidly in the 1990 s, creating concern about the potential for degradation of water in local aquifers. From August 1994 through October 1997, the U.S. Geological Survey, in cooperation with the Ravalli County Board of Commissioners and the Bitterroot Conservation District, conducted a study of the aquifers underlying the Bitterroot Valley. This report describes the hydrogeology and assesses the sensitivity of the aquifers to degradation.

The 7-mile wide by 52-mile long Bitterroot Valley is drained by the north-flowing Bitterroot River, whose flood plain extends the length of the valley and is bounded by high terraces on the east and west. The valley is situated in a structural basin surrounded by intrusive, metasedimentary, metamorphic, and volcanic rocks. Tertiary sediments overlie bedrock and occur as two distinct geological units--the ancestral Bitterroot River deposits, which generally are coarse grained, well sorted, and as much as 2,400 feet thick, and the overlying alluvial-fan deposits, which are composed of locally derived, poorly sorted erosional debris of the adjacent mountains. The bedrock and Tertiary sediments are overlain by Quaternary till, alluvial-fan deposits, alluvium, and terrace deposits.

Most wells in the Bitterroot Valley are completed in unconfined to semiconfined aquifers contained in Quaternary and Tertiary basin-fill deposits. On the basis of data from 9,424 wells, the shallowest staticwater levels and the largest values for yield and specific capacity typically are associated with wells completed in Quaternary deposits. Conversely, the deepest staticwater levels and smallest values for yield and specific capacity typically are associated with wells completed in Tertiary alluvial-fan deposits. Hydraulic characteristics of the ancestral Bitterroot River deposits are between these extremes. The hydraulic characteristics of the aquifers did not vary significantly between the eastern and western sides of the valley.

Regionally, the direction of ground-water flow is from the mountain fronts along the basin margins toward the center of the basin and diagonally downvalley. Hydraulic gradients are steepest in the principal recharge areas near the mountain fronts and more gradual in discharge areas along the flood plain of the Bitterroot River. The basin-fill aquifers are recharged by infiltration of streamflow and irrigation water, subsurface inflow from bedrock, and direct infiltration of precipitation and snowmelt. Greater precipitation on the western side of the valley results in greater recharge there than on the eastern side of the valley. Groundwater discharge is by seepage to springs and streams, evapotranspiration, and withdrawals from wells.

Water in the basin-fill aquifers is primarily a calcium bicarbonate type. The median specific conductance of 240 ground-water samples was 246 microsiemens per centimeter at 25 degrees Celsius and the median nitrate concentration in 239 samples was 0.63 milligrams per liter as N. Samples from 20 wells had nitrate concentrations exceeding 3 milligrams per liter. The largest nitrate concentration was 5.9 milligrams per liter. Specific-conductance values and nitrate concentrations generally were greater on the east side of the valley. Nitrate concentration varied seasonally in water from 16 wells that were sampled approximately bimonthly for 1 year. The median radon concentration in 43 ground-water samples was 810 picocuries per liter; the concentration in 38 samples exceeded 300 picocuries per liter.

Although the relatively small nitrate concentrations indicate that the total nitrate load to the sampled aquifers has not resulted in nitrate concentrations that exceed recommended standards to date, some parts of the study area are more sensitive to degradation than others. The sensitivity of the area aquifers to nitrate loading is most strongly related to the total groundwater recharge--the greater the recharge, the less sensi- 
tive is the aquifer to nitrate loading. Ground-water recharge is directly related to the average annual precipitation and inversely related to the occurrence of low permeability surface deposits, such as Tertiary alluvial-fan deposits, in the respective area.

\section{INTRODUCTION}

The Bitterroot Valley is located in Ravalli County of western Montana (fig. 1). During the early 1990 s, the estimated population of Ravalli County increased at the fastest rate in the State (38 percent), changing from 25,075 in 1990 to 34,554 in 1997 (U.S. Bureau of the Census, issued annually). Most of the residents of Ravalli County live on the Bitterroot Valley floor within a few miles of the river. Much of the increase in population has been outside of established cities and towns and is generally concentrated in housing areas where each dwelling has its own well and septic system. Under unfavorable conditions, the local aquifers have the potential to become degraded owing to continued growth. However, sufficient data were not available to determine the effects of this growth and to identify the areas where the aquifer may be sensitive to potential degradation.

From August 1994 through October 1997, the U.S. Geological Survey (USGS), in cooperation with the Ravalli County Board of Commissioners and the Bitterroot Conservation District, conducted a study of the aquifers underlying the Bitterroot Valley. The study was designed to expand knowledge of the ground-water system through a systematic program of data collection, research, and analysis. The results of the study will be useful in developing a comprehensive management program for the use and protection of the ground-water resources of the Bitterroot Valley.

\section{Purpose and Scope}

This report describes the hydrogeology of the Bitterroot Valley and assesses the sensitivity of the aquifers underlying the benches along the west and east sides of the valley to degradation. Specific objectives were to:

1. Establish a ground-water-level and groundwater-quality monitoring network to obtain base-line information and to document changes in water levels and quality since previous studies.
2. Implement a geographically indexed, computer-based data framework to provide a basis for future assessment of effects from various ground-water management options.

3. Define ground-water flow paths, groundwater-recharge sources, and ground-water-discharge areas.

4. Characterize any potential sources of groundwater-quality degradation and identify areas with existing degradation.

The study was conducted at two different scales: a reconnaissance-level investigation of most of the valley floor and bench areas along the east and west margins of the valley, and a more detailed investigation of three "focus areas" on the benches. The reconnaissance-level investigation was designed to obtain baseline data in the valley where existing hydrologic data were sparse. Detailed investigations were aimed at areas undergoing development or likely to undergo development in the near future. The three focus areas, which were selected to be representative of specific hydrologic and physiographic settings in the valley, are all undergoing rapid residential development.

To determine the geometry and hydraulic properties of the basin-fill aquifers, and to identify any spatial trends in the data, a retrieval from the Montana Ground Water Information Center (GWIC) data base (Groundwater Information Center, Montana Bureau of Mines and Geology, unpub. data, 1996) was converted to geographic-information-system (GIS) format. This data base contains well-completion reports supplied by drillers for 9,424 wells in the study area. Water levels in 25 of these wells have been monitored quarterly by the Montana Bureau of Mines and Geology (MBMG) for the period 1993-96.

A total of 263 wells were inventoried for this study and the information was entered into the USGS National Water Information System data base. When possible, data for these wells were cross-referenced with the GWIC data base. Water levels were measured in 221 of the wells. Fifty-four of the wells were selected a monitoring network, in which water levels were measured approximately bimonthly during the study. Specific conductance and water temperature were measured onsite at 240 wells, and water-quality samples were collected and analyzed for nitrate, chloride, and sulfate at 239 of these wells during the study. Additional data collected prior to this study and by 


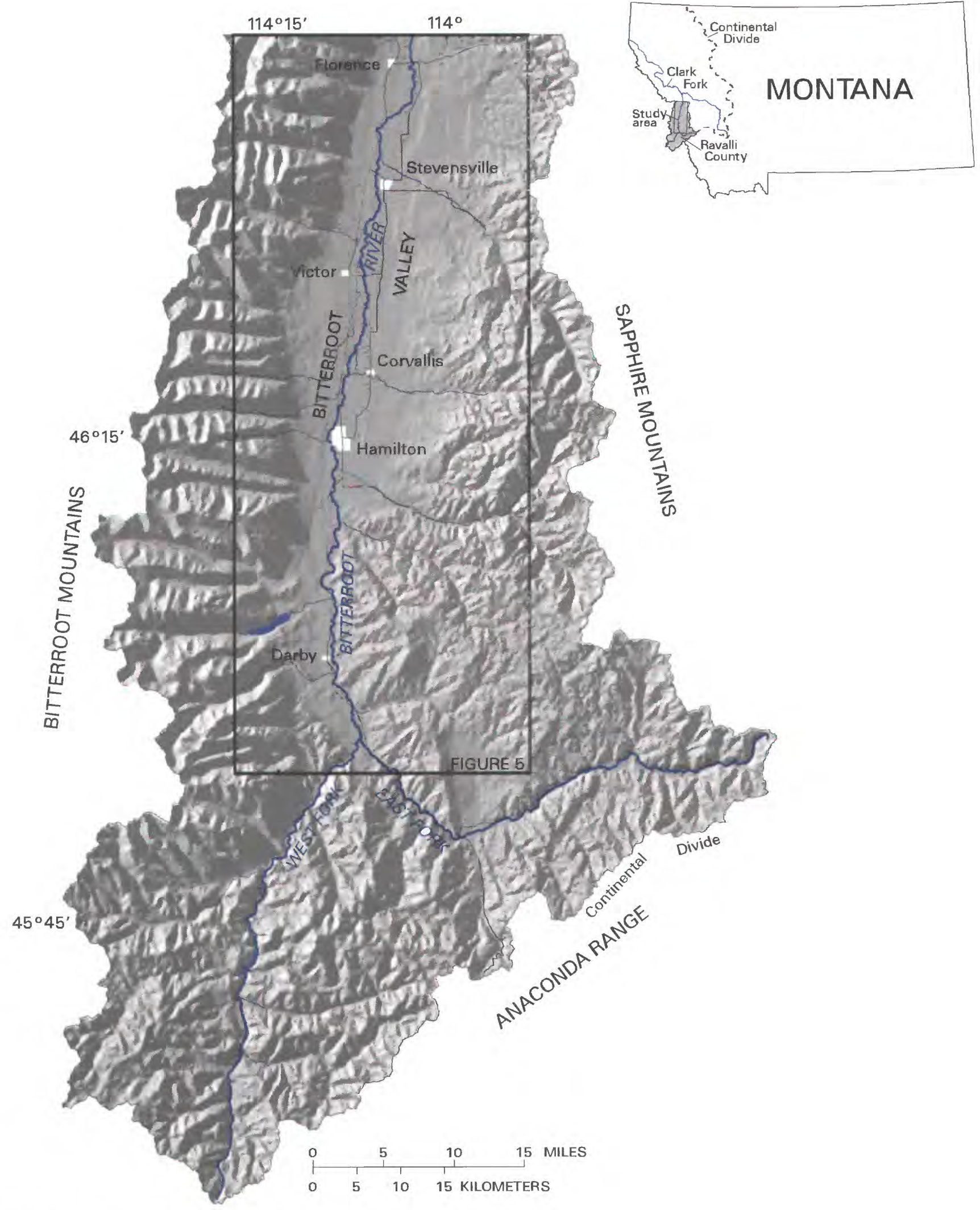

Base from Defense Mapping Agency digital data, 1:250,000, 1975, and

U.S. Geological Survey digital data, $1: 100,000,1983$. Albers Equal Area

Conic Projection Standard parallels $44^{\circ} 00^{\prime}$, and $48^{\circ} 00^{\prime}$, central meridian $-114^{\circ} 00^{\prime}$.

Figure 1. Location of study area within the Bitterroot River drainage basin, Ravalli County, Montana. 
MBMG are included in tables 4-7 in the Supplemental Data section at the back of this report.

Water samples were collected from 43 wells, 3 streams, 1 irrigation canal, and 1 spring for laboratory analysis of major-ion and trace-element concentrations. Forty-three samples collected from wells were analyzed for radon. Results of an additional 24 waterquality analyses were obtained from MBMG for 22 of the 25 wells that they monitor in the study area and results of 26 analyses from previous USGS studies in the valley were included in the data tables.

Digital GIS datasets were compiled for the study area. Thematic layers compiled include hydrography, transportation, precipitation, public land survey, and digital elevation models. In addition, all project data were entered into the GIS data base to allow spatial analysis of the various data.

\section{Previous Investigations}

The USGS and MBMG conducted a study of the geology and water resources of the Bitterroot Valley from Florence south to Darby from 1955 to 1960 (McMurtrey and others, 1972). The study included a detailed annual budget for surface water and a complete hydrologic budget for 1958 and 1959. Information compiled as part of the study included records of wells, multiple water-level measurements in about 30 wells, water-quality analyses for 20 wells, and maps of basin-fill geology, water-table surface, and potential yield of wells. Norbeck (1980) presented a preliminary evaluation of deep aquifers in the valley based on test drilling of five wells in the valley, the deepest of which was $2,700 \mathrm{ft}$. Two recent University of Montana master's theses (Finstick, 1986; Uthman, 1988) have addressed the hydrogeology of parts of the Bitterroot Valley. These theses include information on monthly water levels in a series of observation wells and analyses of water samples collected from a network of wells. During 1991 and 1992, additional information collected by the USGS as part of a regional study (Clark and Dutton, 1996) included water levels in about 100 wells and water-quality analyses for samples from 26 wells. Water levels in five wells in the area have been measured at various intervals since 1960 as part of the USGS statewide monitoring network. Reports of additional investigations of the Bitterroot Valley are listed in the "Selected References" section at the back of this report.
Previous studies in the Bitterroot Valley provide information on the geologic history, surface-water quantity, and water-level fluctuations. However, the data are not sufficient to achieve the objects of this study.

\section{Location-Numbering System}

In this report, wells, one spring, and surfacewater measurement sites are numbered according to geographic position within the rectangular grid system used for the subdivision of public lands (fig. 2). The location consists of as many as 14 characters. The first three characters specify the township and its position north $(\mathrm{N})$ of the Montana Base Line. The next three characters specify the range and its position west (W) of the Montana Principal Meridian. The next two characters are the section number. The next three or four characters sequentially designate the quarter section (160-acre tract), quarter-quarter section (40-acre tract) quarter-quarter-quarter section (10-acre tract), and quarter-quarter-quarter-quarter section (2 1/2-acre tract), respectively, in which the well, spring, or surface-water site is located. The locations of subdivisions within a section are designated $\mathrm{A}, \mathrm{B}, \mathrm{C}$, and $\mathrm{D}$ in a counterclockwise direction, beginning in the northeast quadrant. The final two characters are a sequence number assigned to differentiate multiple wells at a single site; for example, well 10N20W02ABBC01 (fig. 2) is the first well inventoried in the SW1/4NW1/4 NW1/4NE1/4 of sec. 2, T. 10 N., R. 20 W.

\section{Acknowledgments}

The authors thank the members of the Bitterroot Water Forum--a citizens' group addressing waterresource issues in the Bitterroot Valley--for their support and interest during this study. In addition, we acknowledge the contribution of Ann M. Stewart, a graduate student from the University of Montana Department of Geology, who conducted much of the field work in the Eightmile focus area and assisted with water-quality sampling throughout the study area. Finally, we acknowledge the cooperation of the many landowners who provided access to their land and contributed valuable information about the occurrence and use of water resources in the Bitterroot Valley. 


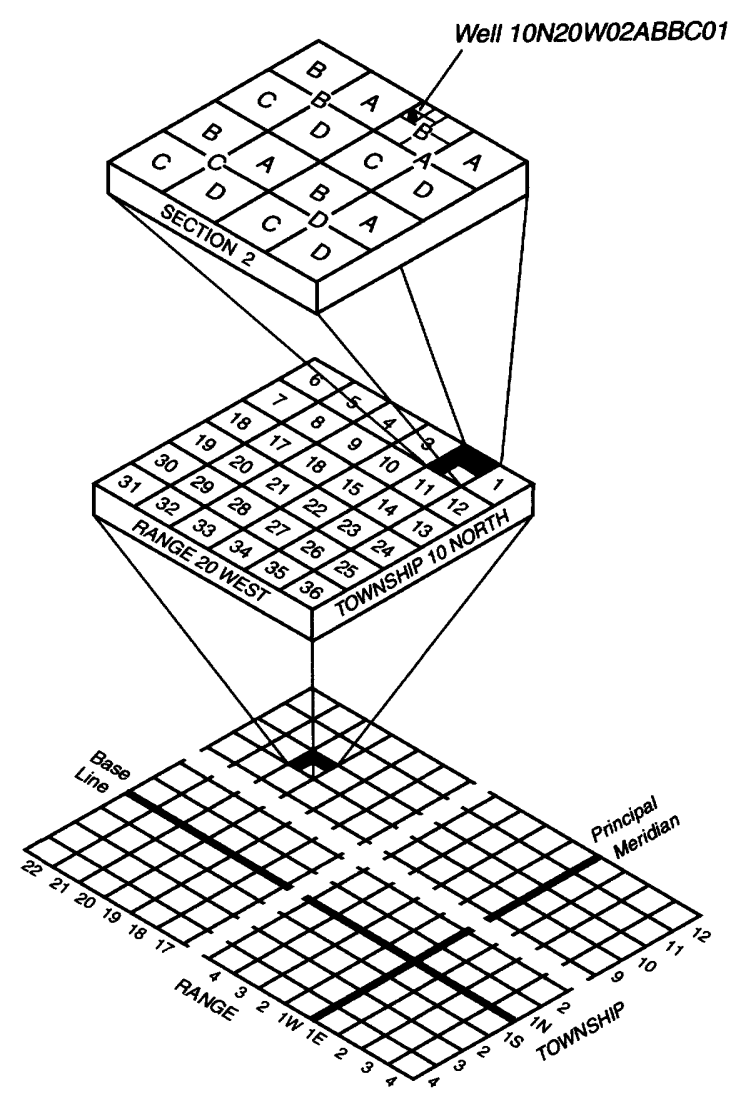

Figure 2. Location-numbering system.

\section{DESCRIPTION OF STUDY AREA}

The Bitterroot Valley is situated in a north-trending intermontane basin in the Northern Rocky Mountains physiographic province (Fenneman, 1931). The valley is bordered on the west by the Bitterroot Mountains, on the east by the Sapphire Mountains, and on the southeast by the Anaconda Range (fig. 1). The valley averages about $7 \mathrm{mi}$ wide and is about $52 \mathrm{mi}$ long in the study area. Basin-fill sediments extend from near the confluence of the East and West Forks of the Bitterroot River in the southern part of the study area to the Ravalli County line north of Florence and encompass about $380 \mathrm{mi}^{2}$, or about 16 percent of the $2,400 \mathrm{mi}^{2}$ part of the drainage basin in Ravalli County.

Land use in the Bitterroot Valley historically has been dominated by irrigated agriculture with some dryland farming along the eastern margin. Most farms also have beef or dairy cattle and are smaller than 50 acres (McMurtrey and others, 1972). Currently, hay and pasture and some apple orchards are the main irrigated crops. Dryland wheat and barley are grown on the eastern benches which are also used for rangeland (Kendy and Tresch, 1996). The conversion of agricultural land for residential development is the major land use change occurring in the Bitterroot Valley today.

\section{Physiography and Drainage}

The Bitterroot Valley contains two principal topographic features and related aquifers. In the center of the valley is the flood plain of the Bitterroot River, which generally is 1 to 2 mi wide and extends the length of the valley. Adjacent to the flood plain along the west and east sides of the valley are extensive high benches that range in width from 3 to $6 \mathrm{mi}$. These benches typically slope toward the flood plain at from $4^{\circ}$ or $5^{\circ}$ near the basin margins to less than $1^{\circ}$ near the flood plain. Benches on the east side of the basin have smooth topography and generally end in 50- to $150-\mathrm{ft}$ scarps at the flood plain, whereas benches on the west side of the basin are dissected and merge gently with the flood plain. This report refers to all sediments east 
of the Bitterroot River flood plain as east-side sediments and all sediments west of the Bitterroot River flood plain as west-side sediments. The Bitterroot Valley in the study area ranges in altitude from about 3,200 $\mathrm{ft}$ where the Bitterroot River flows out of the study area on the north to about $5,500 \mathrm{ft}$ on the highest terrace.

The major surface-water artery of the Bitterroot Valley is the Bitterroot River, which originates in the southern Bitterroot Mountains and the Anaconda Range and flows northward to its confluence with the Clark Fork about 15 mi north of the study area. About 4 times as many tributaries join the river from the Bitterroot Mountains on the west as from the drier Sapphire Mountains on the east. Natural flows of the Bitterroot River and its tributaries typically peak in the spring, decline through the summer, and remain relatively stable through the winter. About 55 percent of the total annual streamflow in the river discharges in May and June in response to snowmelt and rainfall (McMurtrey and others, 1972). During the summer, irrigation withdrawals significantly reduce flow in the Bitterroot River and some of its tributaries; some reaches downstream from Hamilton routinely approach the minimum flows required to support fisheries (Nunnallee and Botz, 1976). However, part of the diverted water eventually drains back into the river system as irrigation return flow. The U.S. Soil Conservation Service (1947) estimated irrigation return flow to the Bitterroot River was about 280,000 acre-ft/yr when precipitation is normal, and about 216,000 acre- $\mathrm{ft} / \mathrm{yr}$ when precipitation is below normal.

McMurtrey and others (1972) calculated water budgets for the Bitterroot River south of the Ravalli County line for water years 1958 and 1959. On average, 1,772,000 acre- $\mathrm{ft} / \mathrm{yr}$ flowed into the basin. Of this total entry, 52 percent was from the west, 37 percent was from the south, and 11 percent was from the east. The average discharge of the Bitterroot River as it left the study area near Florence was 1,540,000 acre-ft/yr; thus, an estimated $232,000 \mathrm{acre}-\mathrm{ft} / \mathrm{yr}$, or 13 percent of the total surface-water inflow, was lost to irrigation, evapotranspiration, and other consumptive uses. Average annual streamflow at USGS gaging station 12344000, Bitterroot River near Darby, was about 8 percent greater during the present study period (water years 1994-97) than during the period analyzed by McMurtrey and others (1972).

\section{Climate}

The climate of the Bitterroot Valley is typical of mid-altitude intermontane basins of the Northern Rocky Mountains west of the Continental Divide, with cold winters, mild summers, and varied precipitation. On the basis of the 1961-90 period of record, the average annual precipitation at Hamilton (altitude 3,640 ft) is $13.28 \mathrm{in}$., and the average annual temperature is 44.8 ${ }^{\circ} \mathrm{F}$ (National Oceanic and Atmospheric Administration, 1992). The average last occurrence of freezing temperatures is May 30, and the average first occurrence is September 10 (Natural Resources Conservation Service, U.S. Department of Agriculture, unpub. data., 1994). Thus, the average growing season is about 103 days long. Precipitation at higher altitudes of the Bitterroot Mountains along the western margin of the drainage basin is about $45 \mathrm{in} / \mathrm{yr}$ in the south and central parts of the valley and more than $80 \mathrm{in} / \mathrm{yr}$ in the north (fig. 3). In contrast, precipitation along the crest of the Sapphire Mountains on the eastern margin of the drainage basin is about 25 to $35 \mathrm{in} / \mathrm{yr}$. Monthly precipitation for the study period and mean monthly precipitation for the period 1961-90 at Hamilton are shown in figure 4.

\section{Delineation of Focus Areas}

To provide a more in-depth investigation of selected parts of the study area, three focus areas were chosen on the basis of physiography, geology, climate, effect of irrigation, and development pressure. These focus areas are referred to in this report as the Eightmile, Hamilton West, and Hamilton Heights areas (fig. 5).

The Eightmile area is located east of Florence and encompasses about $6.8 \mathrm{mi}^{2}$ of the lower part of the Eightmile Creek drainage basin. The physiography of the area is dominated by the alluvial plain of Eightmile Creek, which is bounded on the north and south by low hills of Tertiary sediments. The geologic source area for the near-surface sediments in the Eightmile area is the Sapphire Mountains, which are composed predominantly of metasedimentary rocks (Tuck and others, 1996). Precipitation in the area averages about 14 in/yr. The maximum precipitation in the drainage area upgradient from the Eightmile Creek area is less than $30 \mathrm{in} / \mathrm{yr}$, making it the driest of the three focus areas. Limited diversion of Eightmile Creek locally supplies 


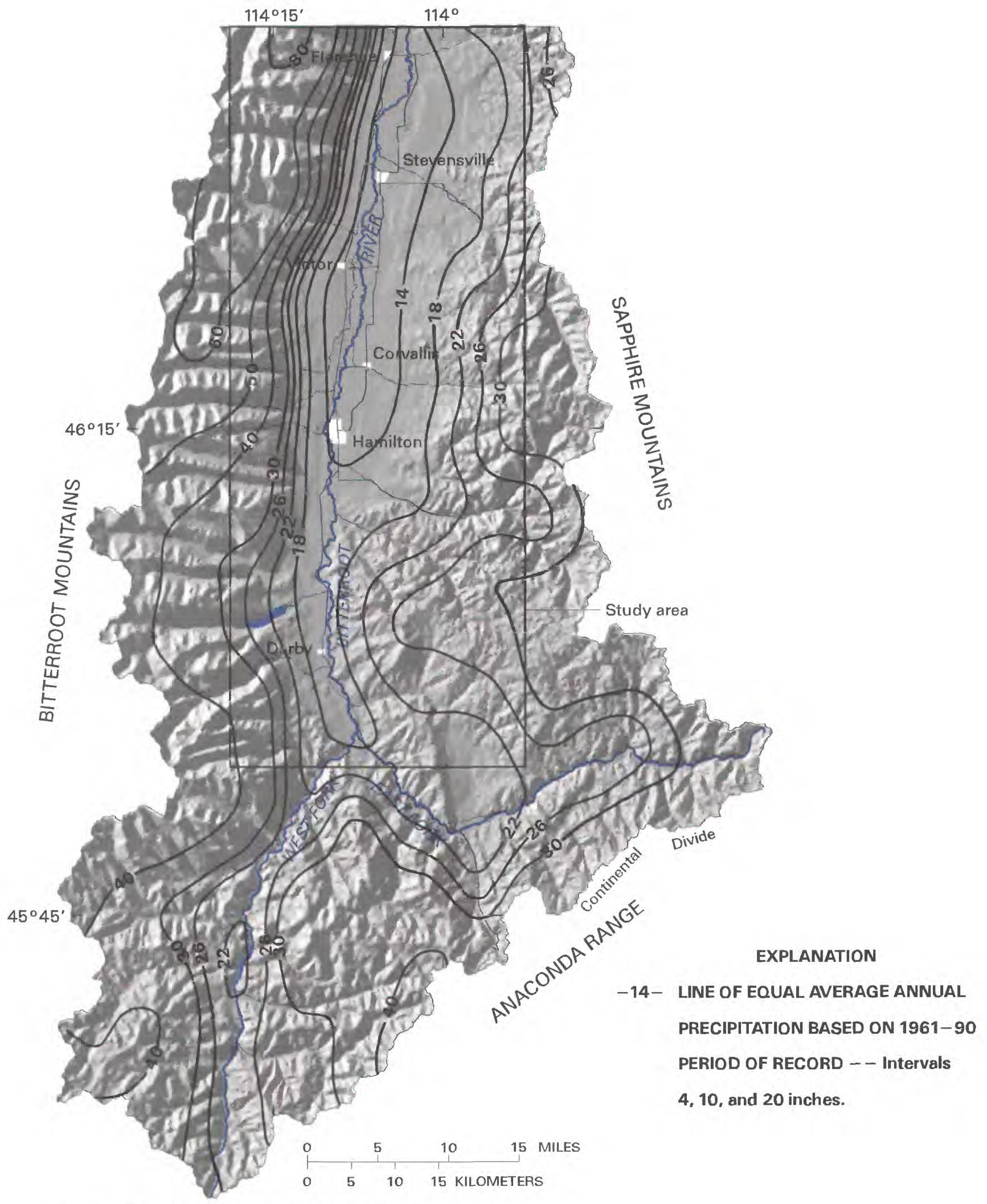

Base from Defense Mapping Agency digital data, 1:250,000, 1975, and

U.S. Geological Survey digital data, 1:100,000, 1983. Albers Equal Area

Conic Projection Standard parallels $44^{\circ} 00^{\prime}$, and $48^{\circ} 00^{\prime}$, central meridian $-114^{\circ} 00^{\prime}$.

Figure 3. Average annual precipitation in Ravalli County. Digital precipitation data compiled by Oregon State University Climate Center (George Taylor, unpublished data, 1995). 


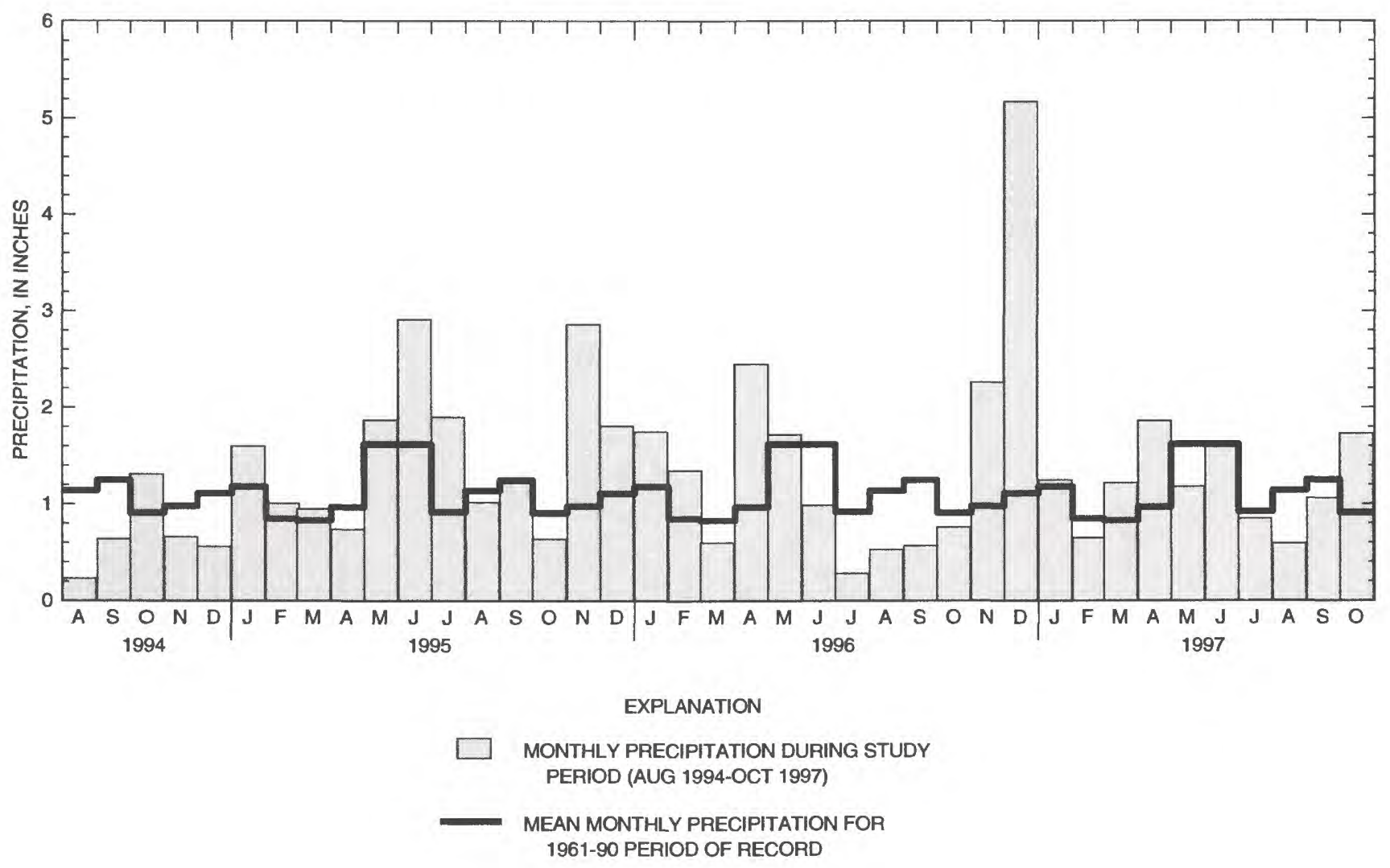

Figure 4. Monthly precipitation for the study period and the mean monthly precipitation for the 1961-90 period of record at Hamilton, Montana. Data from the Western Regional Climate Center, Desert Research Institute, Reno, Nev., 1999.

some water for irrigation. The Bitterroot Irrigation District Canal terminates south of, and therefore does not provide irrigation water to, the Eightmile area.

The Hamilton West area is located just northwest of Hamilton and encompasses about $19.4 \mathrm{mi}^{2}$. The Tertiary benches in the Hamilton West area have been intensively dissected by streams emanating from the Bitterroot Mountains, and the resulting valleys contain Quaternary alluvial-fan deposits and glacial outwash. The principal geologic source area for the near-surface sediments in the Hamilton West area is igneous rocks of the Bitterroot Mountains (Tuck and others, 1996). Precipitation in the area ranges from about $14 \mathrm{in} / \mathrm{yr}$ near the flood plain of the Bitterroot River to about 26 in/yr at the mountain front. Precipitation in parts of the drainage area upgradient from the Hamilton West area is more than $60 \mathrm{in} / \mathrm{yr}$. During the irrigation season nearly all water from local streams is diverted for growing crops.

The Hamilton Heights area is located northeast of Hamilton and encompasses about $19.2 \mathrm{mi}^{2}$. The
Tertiary benches in the Hamilton Heights area are less dissected by streams than those in the Hamilton West area, and large areas of the gently sloping bench surface remains. The geologic source area for most of the near-surface sediments underlying the area is the Sapphire Mountains, which are composed primarily of metasedimentary rocks. Precipitation in the area ranges from about $14 \mathrm{in} / \mathrm{yr}$ near the flood plain of the Bitterroot River to about $18 \mathrm{in} / \mathrm{yr}$ along the Sapphire Mountains to the east of the area. Maximum precipitation in the drainage area upgradient from the Hamilton Heights area is about $35 \mathrm{in} / \mathrm{yr}$. The Hamilton Heights area is the only focus area that receives irrigation water from outside its natural drainage area. Water for irrigation is supplied primarily by the Bitterroot Irrigation District Canal (fig. 5), which transports water from Lake Como in the Bitterroot Mountains northwest of Darby to most of the benches on the east side of the valley. Water for irrigation is also supplied by the Republican and Hedge Ditches (fig. 17), which divert water from the Bitterroot River south of Hamilton. The 


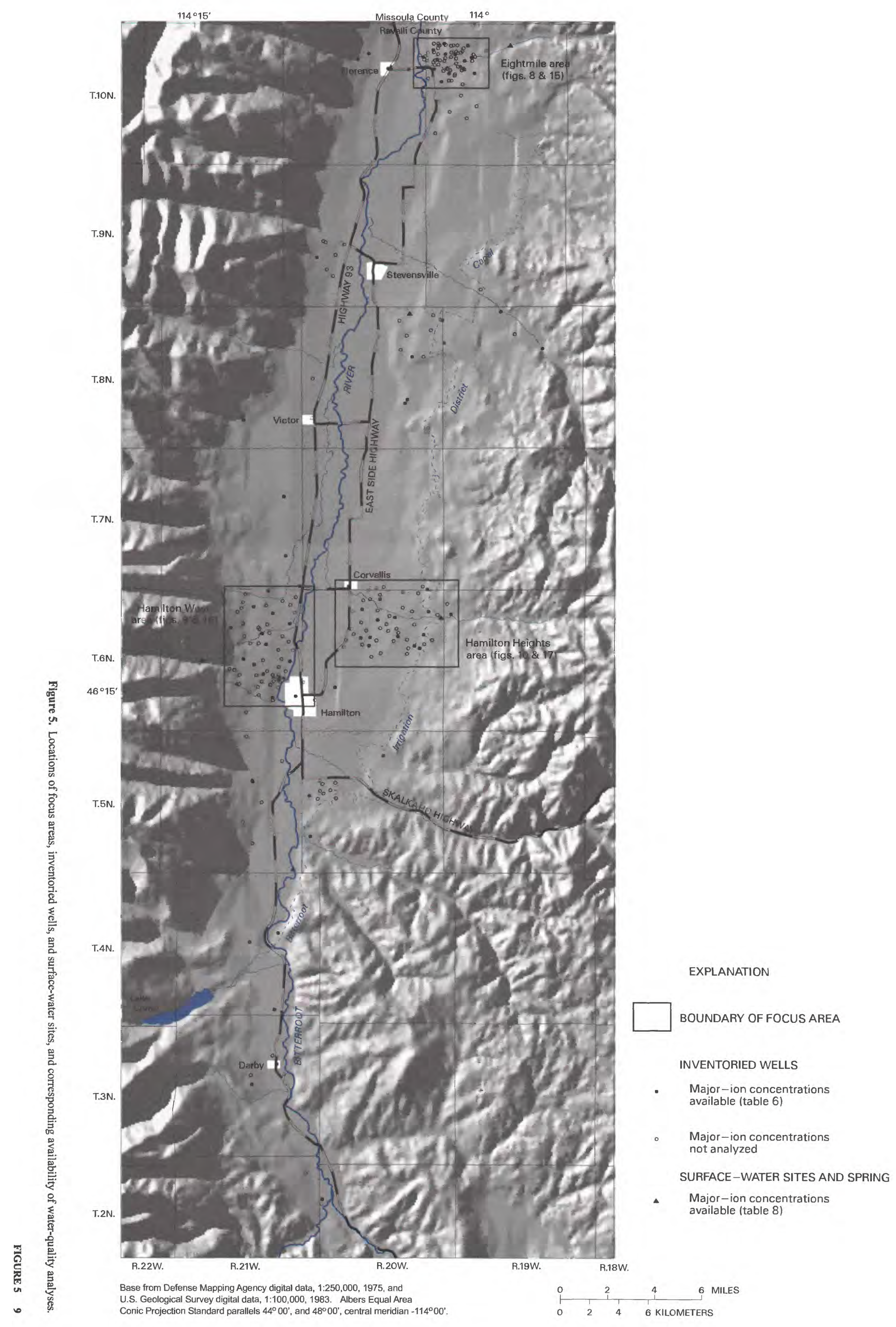


canals transport water from about mid-April through October.

\section{HYDROGEOLOGY}

Ground-water flow in the Bitterroot Valley is strongly controlled by the depositional history, topographic setting, and hydraulic character of the geologic units in the area. Recent work by Lonn and Sears (1998) indicates that the basin-fill geology of the Bitterroot Valley includes extensive coarse-grained, water-yielding deposits that are not found in other basins in southwest Montana.

\section{General Geology}

The Bitterroot Valley is situated in a structural basin most probably formed by crustal extension during the middle Eocene Epoch (Hodges and Applegate, 1993). Gravity data indicate a distinct, relatively straight western basin margin along the Bitterroot Mountains, in contrast to an irregular eastern margin along the Sapphire Mountains (Noble and others, 1982). Gravity and magnetic data indicate that basinfill sediments attain a maximum thickness of at least 3,000 ft near Corvallis and Hamilton (Noble and others, 1982; Crosby, 1976). A surficial geology map of the study area is presented as figure 6 .

Intrusive, metasedimentary, metamorphic, and volcanic rocks border the Bitterroot Valley. West and south of the basin, the Bitterroot, Anaconda, and southern Sapphire Mountains are composed of Cretaceous granitic rocks associated with the Idaho Batholith. These rocks are mostly gray quartz monzonite with some granodiorite and anorthite. Along the western basin margin, the granitic rocks are bordered by gneiss, which averages about 2,000 $\mathrm{ft}$ thick. East of the basin, the Sapphire Mountains are composed mostly of metasedimentary rocks of the Middle Proterozoic Belt Supergroup that include quartzites, quartzitic and calcareous argillite, and argillaceous limestone. Tertiary volcanic rocks, ranging in composition from acidic to basic, crop out locally near fault zones along basin margins (McMurtrey and others, 1972).

Tertiary sediments overlie bedrock throughout the basin and crop out on the eastern and, to a lesser extent, western benches. Tertiary sediments also occur at depth beneath the benches, beneath a veneer of Quaternary alluvium along the Bitterroot River flood plain, and beneath Quaternary alluvial fans along the floors of tributary valleys. These unconsolidated to semiconsolidated Tertiary deposits are composed of gravel, sand, silt, and clay that occur as two distinct geologic units: the ancestral Bitterroot River deposits and the Sixmile Creek Formation (Lonn and Sears, 1998).

The ancestral Bitterroot River deposits--the lower of the two Tertiary units in the basin--are composed of well-sorted, well-rounded, well-stratified, light-gray to white cobbles, gravel, and sand that are locally interbedded with silt and clay (Lonn and Sears, 1998). Clast lithologies are representative of rocks from the entire drainage basin, with several distinctive clast types indicating transport from the far southwestern end of the basin and possibly even beyond. The remote source area for many of the rocks, the wellsorted and well-stratified nature of the deposit, and the age dates of ash and gneiss pebbles of 39 and 45 million years, respectively, indicate that the ancestral Bitterroot River deposits were most likely deposited by a northward through-flowing river of regional scale during the middle Eocene to middle Miocene Epochs (James Sears, Department of Geology, University of Montana, written commun., 1997). Deep drill holes show that unconsolidated sediments similar to the ancestral Bitterroot River deposits are as much as $2,400 \mathrm{ft}$ thick in places (Norbeck, 1980).

The Sixmile Creek Formation, which overlies the ancestral Bitterroot River deposits, is composed of brown, unconsolidated to weakly lithified, poorly sorted, moderately stratified, subangular to rounded boulders and cobbles in a sandy silt and clay matrix deposited in alluvial-fan environments. These sediments represent the locally derived, poorly sorted erosional debris of the adjacent mountains deposited in arid conditions during the late Miocene and Pliocene Epochs, when flash floods are thought to have transported loose rock and soil from adjacent canyons in massive mud-rock slurries. This formation is identified as Tertiary alluvial-fan deposits in figure 6. The Sixmile Creek Formation contains abundant brown, massive, micaceous silt beds and clasts commonly coated by iron oxide or caliche (Lonn and Sears, 1998). Bedding typically dips more steeply than the present surfaces of these deposits; therefore, the present surfaces represent erosional pediment surfaces.

Quaternary glacial till underlies many of the high benches along the Bitterroot Mountains, especially in the southern part of the study area west of Darby. 


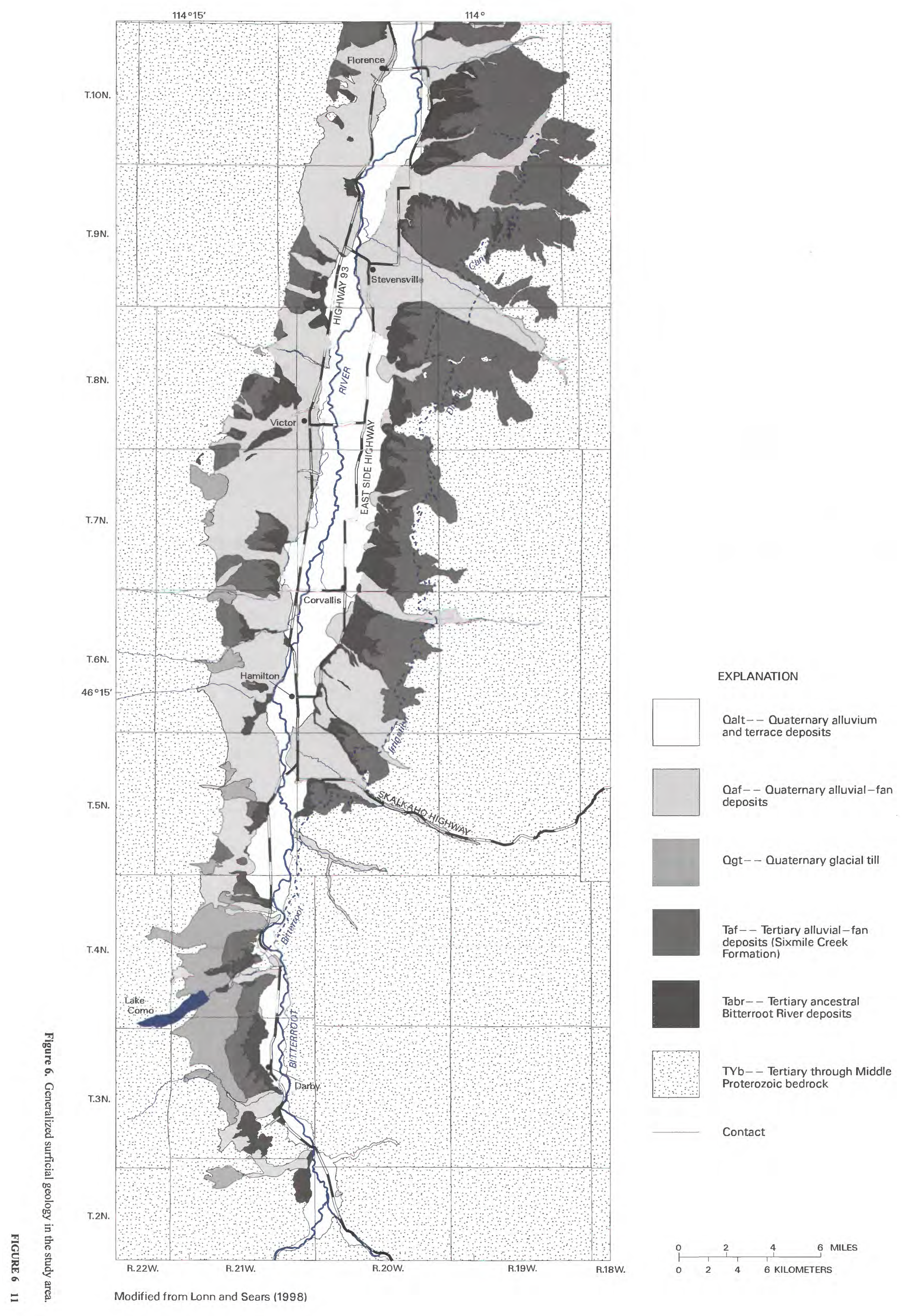


These unsorted, unstratified deposits consist of boulders, cobbles, gravel, sand, silt, and a large amount of clay (Lonn and Sears, 1998). Moraines indicate at least three stages of glaciation beginning in early Pleistocene (Weber, 1972).

Quaternary alluvial-fan deposits are present along much of the western side of the valley and along the larger tributary streams on the eastern side of the valley. These unconsolidated deposits are composed of well-rounded, unweathered cobbles and boulders in a matrix of sand and gravel that were locally derived from bedrock and the reworking of older unconsolidated sediments (Lonn and Sears, 1998). These fans were deposited in braided stream environments and are generally less than $40 \mathrm{ft}$ thick (McMurtrey and others, 1972). Sorting and grain size decrease with distance from the mouths of tributary canyons. On the western side of the valley, Quaternary alluvial-fan deposits include abundant glacial outwash.

Quaternary alluvium and terrace deposits occur along the present flood plain of the Bitterroot River. Alluvium underlies the flood plain of the Bitterroot River and the channels of its major tributaries. Well logs indicate the alluvium has an average thickness of $40 \mathrm{ft}$ (McMurtrey and others, 1972). Quaternary terraces occur adjacent to and 10 to $30 \mathrm{ft}$ above the Bitterroot River flood plain. Both the alluvium and the terrace deposits are composed of material essentially indistinguishable from reworked material of the ancestral Bitterroot River deposits (Lonn and Sears, 1998).

\section{Hydraulic Characteristics of Basin-Fill Deposits}

Most wells in the Bitterroot Valley are completed in basin-fill deposits of Quaternary and Tertiary age. The bedrock surrounding and underlying the basin is not a major aquifer, although wells completed in bedrock may yield small amounts of water from fractures and weathered zones.

Aquifers in the various basin-fill deposits are either unconfined, semiconfined, or confined. Most aquifers in Quaternary alluvium, terrace deposits, and alluvial-fan deposits are unconfined to semiconfined and yield abundant water to wells. These deposits can best be described as a sequence of complexly stratified lenses of cobbles, gravel, and sand with varying amounts of intercalcated silt and clay. The greater the percentage of silt and clay, the greater the likelihood that the aquifer will be semiconfined. In some parts of the study area, aquifers in Quaternary alluvial-fan deposits are confined by overlying till.

Abundant fine-grained layers within Tertiary alluvial-fan deposits of the Sixmile Creek Formation confine water in more permeable layers. With depth, these fine-grained layers become more consolidated and, therefore, less permeable. Aquifers in the Tertiary ancestral Bitterroot River deposits range from unconfined where exposed at the surface to confined where overlain by till or Tertiary alluvial-fan deposits.

Although present in relatively small percentages in the ancestral Bitterroot River deposits, silt and clay form confining layers at depths greater than a few hundred feet.

Although some Tertiary deposits contain productive aquifers, knowledge of the extent and hydraulic character of these water-yielding zones is limited. Aquifers in Quaternary and Tertiary deposits within the basin generally are assumed to be hydraulically connected, with local exceptions.

To assess certain hydraulic characteristics of the geologic units in the valley, the GWIC data base for the study area $(9,424$ wells as of 1994$)$ was input to a GIS and combined with the geologic map data shown in figure 6 to enable the assignment of a geologic unit to each well. Several assumptions were made during the process of assignment. Wells that were deeper than $40 \mathrm{ft}$ and located in map areas identified as Quaternary alluvium and terrace deposits, Quaternary alluvial-fan deposits, or Quaternary glacial till were assumed to be completed in the underlying ancestral Bitterroot River deposits. Likewise, wells that were deeper than $300 \mathrm{ft}$ and located in map areas identified as Tertiary alluvialfan deposits were assumed to be completed in the underlying ancestral Bitterroot River deposits. The resulting GIS data base was used to produce statistics characterizing the depth to static-water level, yield, and specific capacity of wells completed in various geologic units and in various areas of the valley (fig. 7).

Depth to static-water level represents the depth to the water table in an unconfined aquifer and the pressure head in a confined aquifer. An unconfined aquifer with a shallow depth to water is generally more economical to develop given the shallow well-completion depth required, but is also more vulnerable to contamination from surface sources than an aquifer with a greater depth to water. The depth to static-water level 

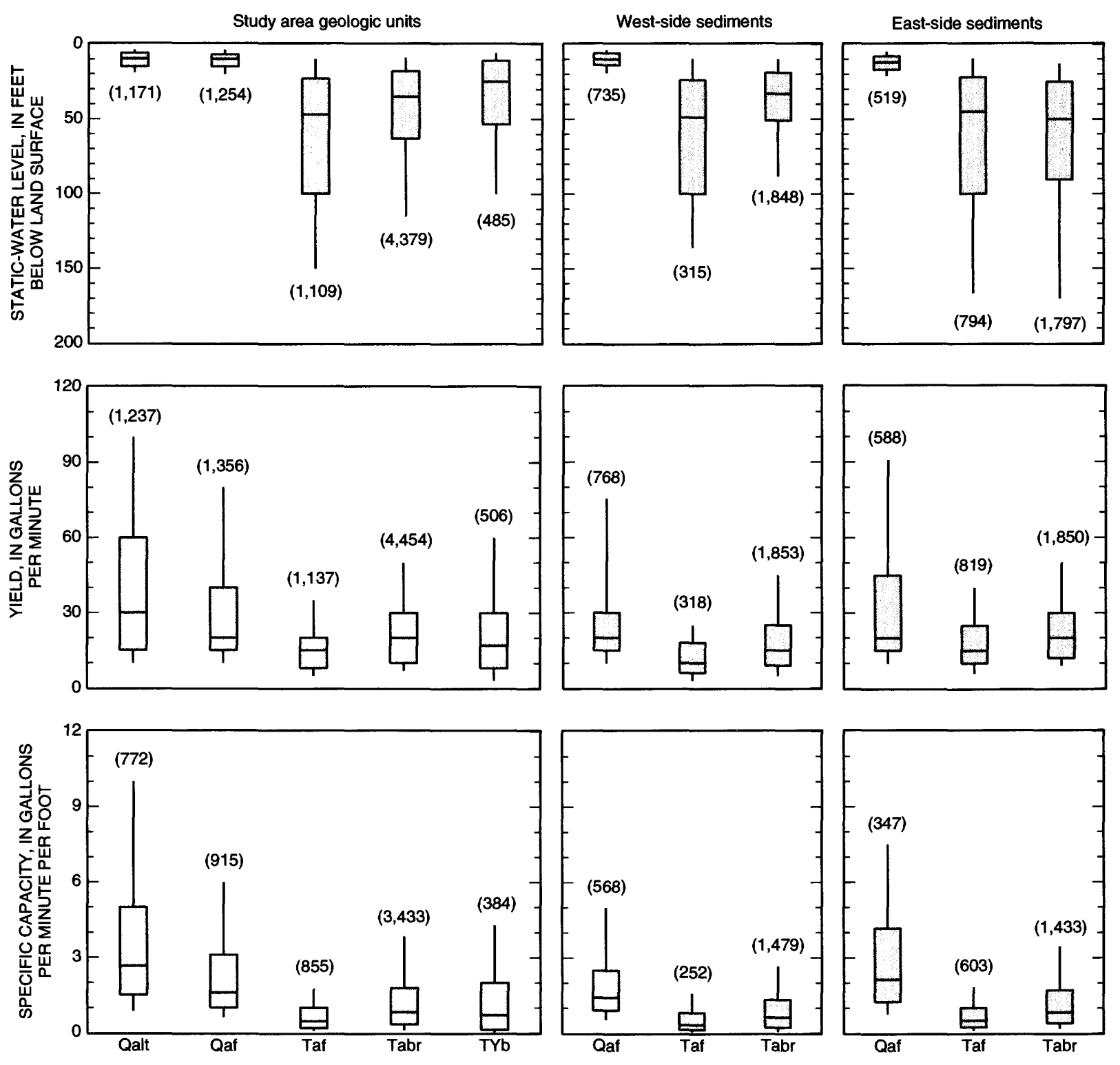

EXPLANATION

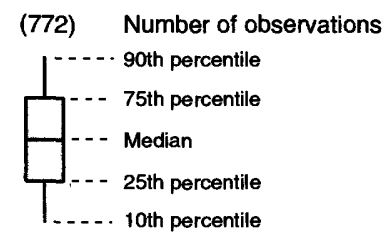

GEOLOGIC UNIT

Qalt--Quaternary alluvium and terrace deposits

Qaf--Quaternary alluivial-fan deposits

Taf--Tertiary alluvial-fan deposits (Sixmile Creek Formation)

Tabr-Tertiary ancestral Bitterroot River deposits

TYb--Tertiary through Middle Proterozoic bedrock

Figure 7. Range of static-water levels, yields, and specific capacities of wells based on geologic unit and location. 
in a confined aquifer generally is not definitively related to the depth of the water-bearing strata.

Well yield is dependent on the capacity of the installed pump, the efficiency of the well, and the ability of the aquifer to supply water to the well. Domestic well yields of less than $10 \mathrm{gal} / \mathrm{min}$ are probably indicative of poor aquifers.

Specific capacity is an expression of the productivity of a well obtained by dividing the well yield by the pumping-induced drawdown in the well. For example, a well that yielded $10 \mathrm{gal} / \mathrm{min}$ with $5 \mathrm{ft}$ of drawdown would have a specific capacity of $2 \mathrm{gal} / \mathrm{min}$ per foot of drawdown. This well would be twice as productive as a well that yielded the same $10 \mathrm{gal} / \mathrm{min}$ but had a pumping-induced drawdown of $10 \mathrm{ft}$ resulting in a specific capacity of $1 \mathrm{gal} / \mathrm{min}$ per foot. Specific capacity is dependent on both the efficiency of the well and the ability of the aquifer to supply water to the well. Assuming that most domestic wells in the study area have similar efficiencies and that variations in well efficiency are randomly distributed throughout the study area, differences in specific-capacity values reported in this analysis could be attributed to differences in the water-yielding capability of the various basin-fill deposits in which the wells are completed.

One limitation of this analysis deserves noting. The GWIC data base contains information about the vast majority of wells completed in the study area but does not contain information about "dry holes" or wells that were never completed because insufficient yield made them unsuitable for their intended use. Therefore, statistics shown in figure 7 for wells completed in geologic units that are relatively poor aquifers such as the Tertiary alluvial-fan deposits might overestimate the median yield and specific capacity of the aquifer.

Wells completed in Quaternary alluvium and terrace deposits had the shallowest static-water levels and the largest values of yield and specific capacity of all geologic units analyzed. These conditions are most likely due to the well-sorted, coarse-grained character of the deposits and their occurrence along the main Bitterroot River flood plain, which is the primary groundand surface-water discharge area for the valley. On the basis of 12 aquifer tests for Quaternary alluvium and terrace deposits, McMurtrey and others (1972) calculated transmissivity values ranging from 2,000 to $38,000 \mathrm{ft}^{2} / \mathrm{d}$.

Wells completed in Quaternary alluvial-fan deposits had static-water levels essentially identical to those for Quaternary alluvium and terrace deposits, but had smaller values for yield and specific capacity. These smaller values are most likely related to the Quaternary alluvial-fan deposits being less well-sorted and finer grained than the alluvium and terrace deposits.

In contrast to wells completed in Quaternary deposits, wells completed in Tertiary alluvial-fan deposits had the deepest static-water levels and smallest values of yield and specific-capacity of all geologic units analyzed. The deep static-water levels in the Tertiary alluvial-fan deposits are due largely to their present topographic position high on the basin margins above the altitude of tributary streams that supply recharge to the Quaternary deposits. The small values for yield and specific capacity of wells completed in Tertiary alluvial-fan deposits result from their finegrained, poorly sorted character and substantial postdeposition compaction, cementation, and weathering, which further reduce permeability.

Wells completed in the ancestral Bitterroot River deposits had values for static-water level, yield, and specific capacity between those for Quaternary deposits and those for Tertiary alluvial-fan deposits. The range in static-water levels in these wells can largely be explained by the topographic position of the parts of the formation that wells penetrate--generally higher in altitude than the Quaternary deposits but lower in altitude than the Tertiary alluvial-fan deposits. The range in values for yield and specific capacity is due largely to the permeability of the deposits which, owing to compaction with time, is less than the permeability of Quaternary deposits but greater than the permeability of the poorly sorted, silt- and clay-rich Tertiary alluvial-fan deposits. Hydraulic-conductivity values for five aquifer tests presented by Norbeck (1980) for two deep test wells $(2,627$ and $1,110 \mathrm{ft})$ completed in the ancestral Bitterroot River deposits range from 2.6 to $6.2 \mathrm{ft} / \mathrm{d}$, which are within the range of expected values for silty to clean sand (Freeze and Cherry, 1979). Based on the geologic origin of these sediments, the deep test-well data, and the extensive statistical summary provided by the GWIC data base analysis, the ancestral Bitterroot River deposits are likely to be a productive aquifer at most locations or depths in the study area.

\section{Ground-Water Occurrence and Movement}

Regionally, the direction of ground-water flow in the Bitterroot Valley is from the mountain front along 


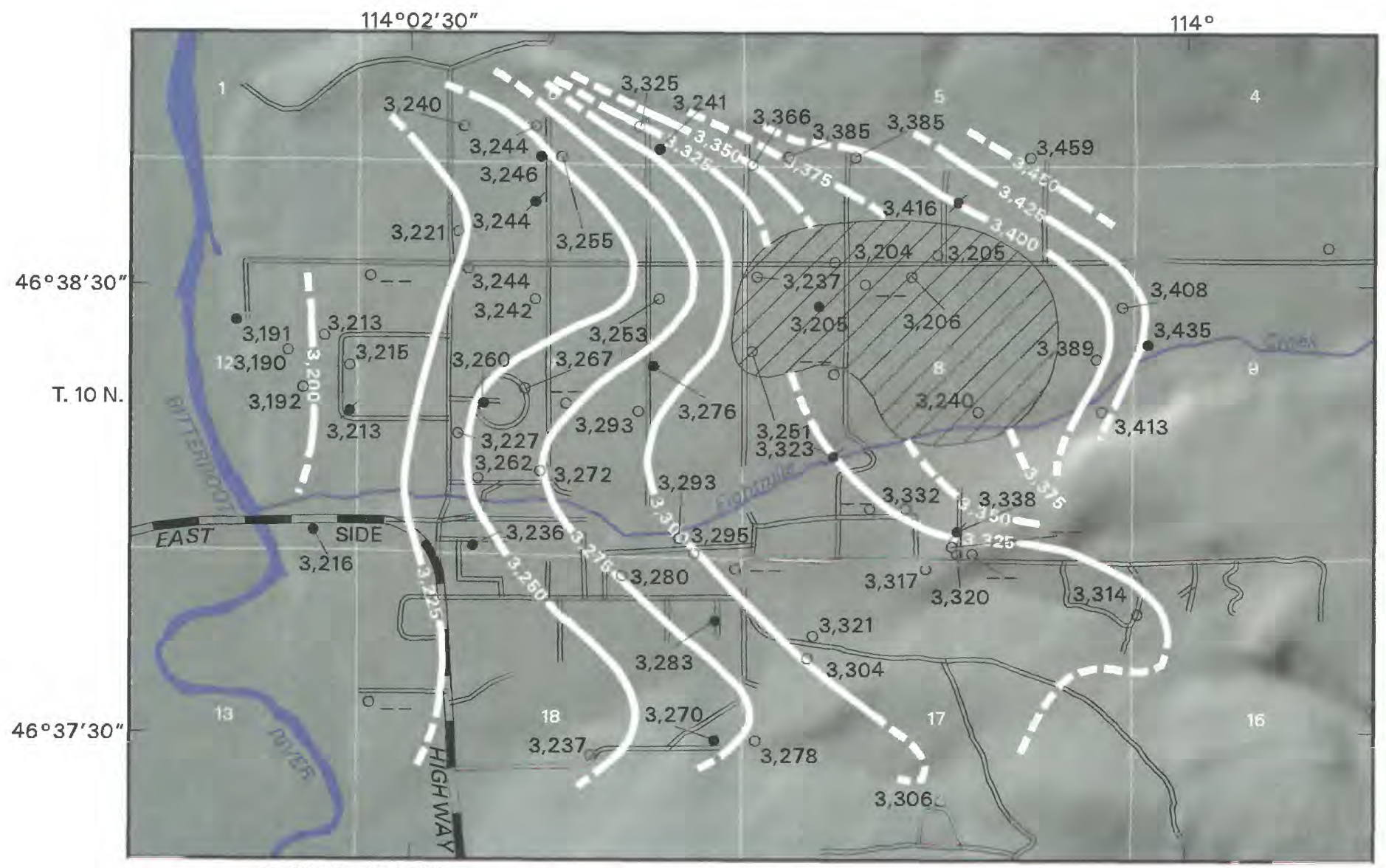

R. 20 W. R. 19 W.

Base from U.S. Geological Survey digital data, 1:24,000, 1979 to present. Albers Equal Area Conic Projection Standard parallels $44^{\circ} 00^{\prime}$, and $48^{\circ} 00^{\prime}$, central meridian $-114^{\circ} 00^{\circ}$.

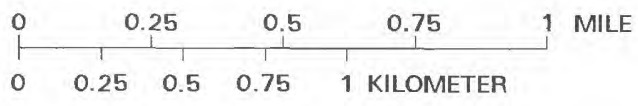

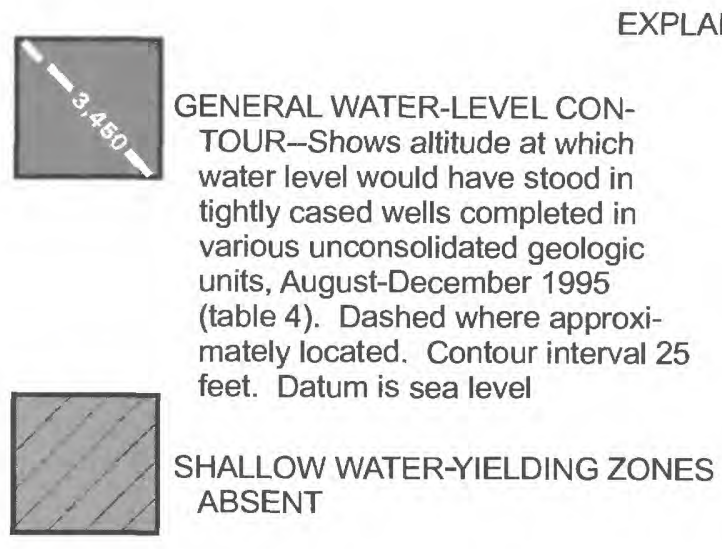

INVENTORIED WELL
Well in water-level
monitoring network
Well in water-level and
nitrate monitoring
networks
Well not in monitoring
network
MEASURED ALTITUDE OF WATER
LEVEL; -, no data for August-
December 1995.

Figure 8. Altitude of the water-level surface and location of monitoring wells in the Eightmile area, 1995. 
the basin margins toward the center of the basin and diagonally downvalley (Briar and others, 1996). The configuration of the water-level surface generally reflects topography, with steeper hydraulic gradients in the recharge areas along the mountain front than in discharge areas along the flood plain of the Bitterroot River. The direction of flow in deeper aquifers might be somewhat different owing to confining strata, faulting, or other deep structural controls (Briar and others, 1996).

Water levels were measured approximately bimonthly in most of the 54 wells of the monitoring network (table 5 and figure 21 in the Supplemental Data section at the back of this report). The altitudes of monitoring wells in the Eightmile area were determined to within $\pm 0.5 \mathrm{ft}$ by instrument leveling from points of known altitude. The altitude of land surface at monitoring wells in the Hamilton West and Hamilton Heights areas was determined from 1:24,000-scale topographic maps and is accurate to within about onehalf the contour interval $( \pm 10 \mathrm{ft})$.

The configuration of the water-level surface in the three focus areas was determined from water levels measured from August through December 1995 (figs. $8-10$ ). Water-levels were manually contoured at a scale of $1: 24,000$. Topography and the altitude of streams and springs were used to position contours between data points. The direction of ground-water flow is perpendicular to the water-level contours and downgradient.

The contours shown in figures 8-10 represent water levels in the depth interval of basin fill in which most wells in the area are completed. Water levels vary with well depth in areas having a vertical component of ground-water flow. Recharge areas along the basin margins commonly have a downward component of flow, whereas discharge areas near streams and rivers in the central parts of the basin have an upward component of flow. Consequently, water-level measurements in individual wells might differ from water levels shown in the figures by tens of feet in some areas. In addition, wells may be completed at different depths and open to different water-yielding zones. For example, well 10N19W06DDCC01 has a water-level altitude in figure 8 of 3,241 feet which differs from the adjacent contours by $60-80$ feet. This well is completed in a deeper water-yielding zone than adjacent wells.
Water-level contours reflect recent hydrologic conditions and development. Seasonal water-level fluctuations in most wells typically range from a few feet to a few tens of feet but do not significantly change the location or shape of the water-level contours at the scale shown. Quarterly water-level data dating back to the late 1950's for three wells (10N20W13ABA01, 08N20W19BAAD03, 08N19W07CBBD01) in the Bitterroot River flood plain near Florence and Hamilton are not significantly different from present conditions. However, changes in irrigation practices and increased withdrawals for domestic use have probably had some effect on water levels in the bench areas. Unfortunately, insufficient data are available to determine long-term changes in ground-water levels throughout most of the study area.

Basin-fill aquifers in the Bitterroot Valley are recharged by infiltration of streamflow and irrigation water, subsurface inflow from surrounding bedrock (which is primarily recharged by melting snowpack), and direct infiltration of precipitation and snowmelt. Discharge from basin-fill aquifers is by seepage to springs and streams, evapotranspiration, withdrawals by wells, and subsurface flow to the north out of the basin.

The potential for natural ground-water recharge to an area is dependent upon the quantity of precipitation that falls on and upgradient from the area. For this discussion, the total area receiving precipitation which could potentially recharge an aquifer through direct infiltration, inflow from bedrock, and leakage from streams, is referred to as the "potential recharge source area." As shown in figure 3, the west side of the Bitterroot Valley receives significantly more precipitation than the east side. The potential recharge source area on the west side is 415,673 acres; this area includes upgradient bedrock and sedimentary deposits on the western side of the valley (areas A and B in fig. 11) and extends from near the confluence of the East and West Forks of the Bitterroot River in the south to the Ravalli County line in the north. This potential recharge source area was combined with the precipitation data presented in figure 3 using a GIS. The analysis indicates that west-side sediments and bedrock receive a total of $1,462,586$ acre- $\mathrm{ft} / \mathrm{yr}$ of precipitation, for an average annual rate of $3.52 \mathrm{ft}$ (42.22 in.) (table 1). In contrast, the potential recharge source area on the east side is 333,560 acres; this area includes upgradient bedrock 


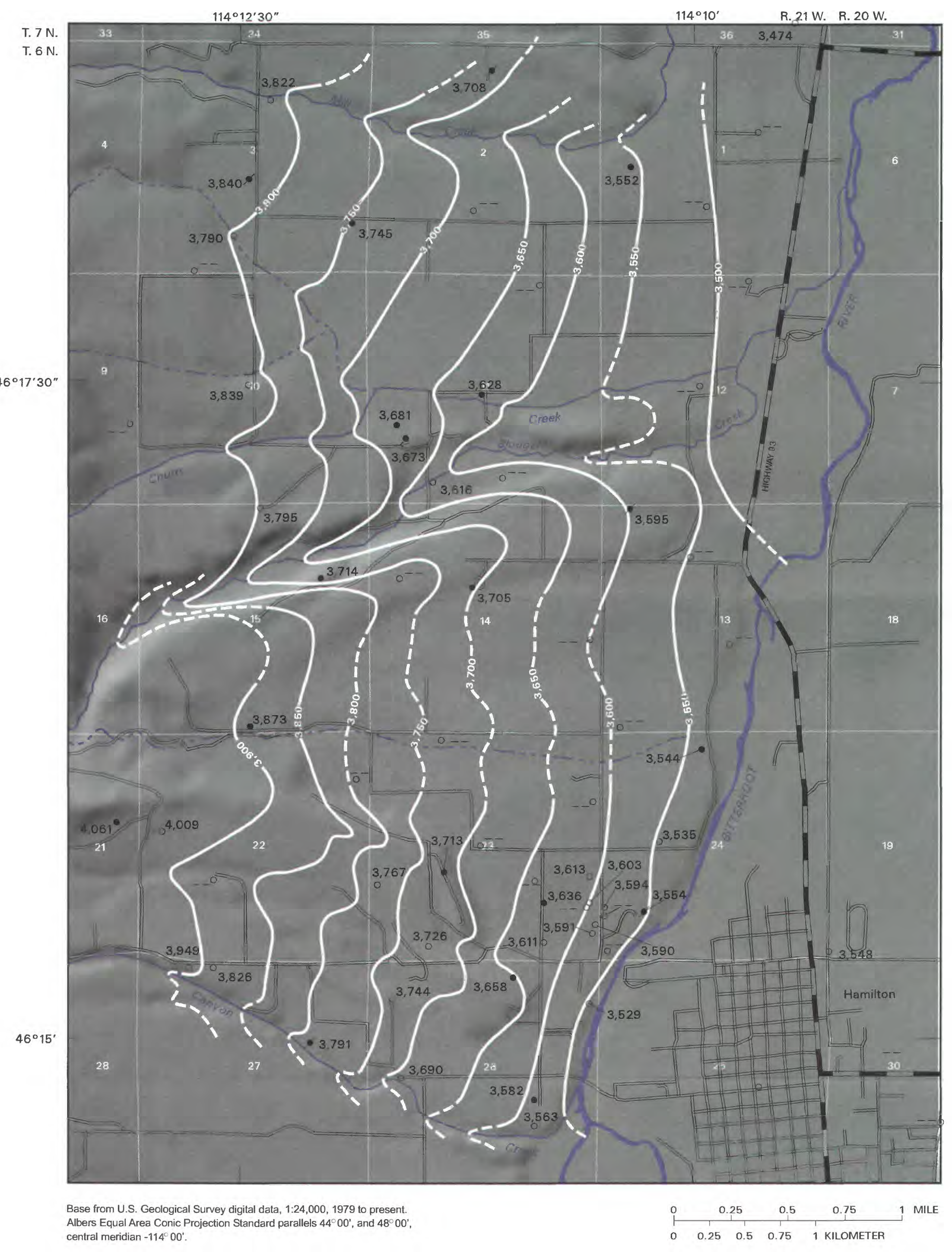

EXPLANATION

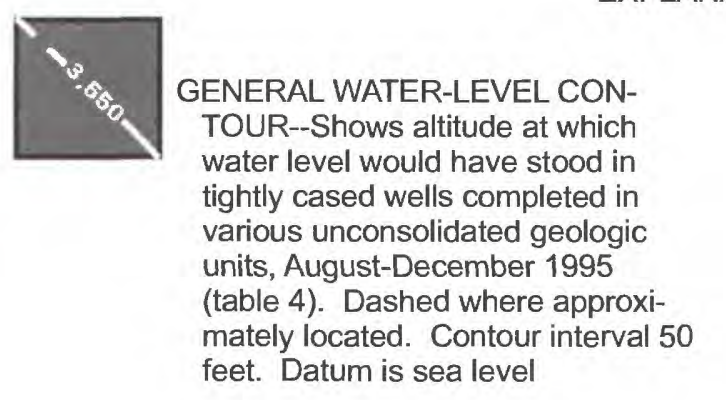

INVENTORIED WELL

Well in water-level

monitoring network

Well in water-level and

nitrate monitoring

networks

feet. Datum is sea level

Well not in monitoring

3,563 MEASURED ALTITUDE OF WATER

LEVEL; --, no data for August-

December 1995 


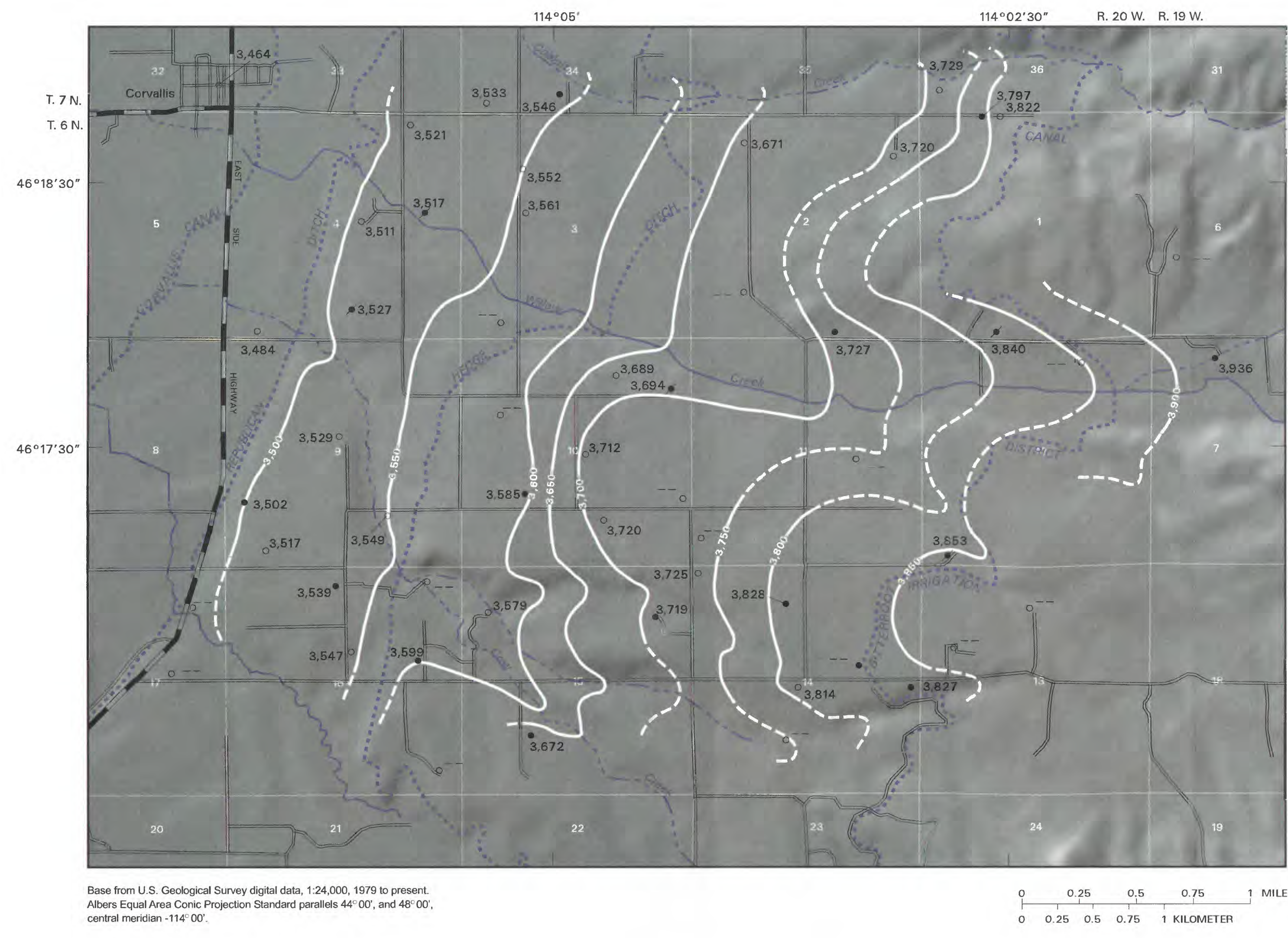

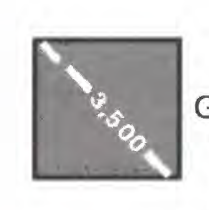

Figure 10. Altitude of the water-level surface and location of monitoring wells in the Hamilton Heights area, 1995
EXPLANATION

ENERAL WATER-LEVEL CONwater level would have stood in tightly cased wells completed in various unconsolidated geologic units, August-December 1995 (table 4). Dashed where approxi-
mately located. Contour interval 50 feet. Datum is sea level INVENTORIED WELL Well in water-level

Wenting Well in water-level and
nitrate monitoring networks

- Well not in monitoring

MEASURED ALTITUDE OF WATER LEVEL; --, no data for August-
December 1995 

Table. 1 Total annual precipitation in selected areas

\begin{tabular}{lccc}
\hline \multicolumn{1}{c}{$\begin{array}{c}\text { Area } \\
\text { (see fig. 11) }\end{array}$} & $\begin{array}{c}\text { Combined } \\
\text { surface area } \\
\text { (acres) }\end{array}$ & $\begin{array}{c}\text { Total annual } \\
\text { precipitation volume } \\
\text { (acre-feet) }\end{array}$ & $\begin{array}{c}\text { Average annual } \\
\text { precipitation } \\
\text { (inches) }\end{array}$ \\
\hline West-side sediments and bedrock (A + B) & 415,673 & $1,462,586$ & 42.22 \\
East-side sediments and bedrock (C + D) & 333,560 & 612,310 & 22.03 \\
Eightmile focus area plus upgradient area (1 + E) & 25,259 & 41,449 & 19.69 \\
Hamilton West focus area plus upgradient area (2+ F) & 50,703 & 174,671 & 41.34 \\
Hamilton Heights focus area plus upgradient area (3+ G) & 36,532 & 64,750 & 21.27 \\
\hline
\end{tabular}

and sedimentary deposits on the eastern side of the valley (areas $C$ and $D$ in fig. 11) and extends from near the Skalkaho Highway in the south to the Ravalli County line in the north. East-side sediments and bedrock are calculated to receive a total of 612,310 acre-ft/yr of precipitation, for an average annual rate of $1.84 \mathrm{ft}$ (22.03 in.). The almost two-fold difference in the quantity of precipitation falling on the western as opposed to the eastern sides of the valley is probably the most significant factor affecting the quantity and quality of ground water in the study area.

The potential recharge source area upgradient from and including each of the three focus areas is also shown in figure 11. The drainage area, total annual precipitation volume, and average annual precipitation in each of the three focus areas is presented in table 1. As shown in the table, average annual precipitation in the area upgradient from and including the Hamilton West area is about twice that of the Eightmile and Hamilton Heights area.

The quantity of precipitation falling in an area represents the upper limit, or maximum potential for natural recharge, not the actual quantity of recharge to underlying aquifers. The percentage of the total available water that actually recharges a specific aquifer is dependent on many complex and interrelated factors whose precise determination is beyond the scope of this study. For example, most precipitation in the areas shown in table 1 occurs at higher altitudes in the mountainous bedrock parts of the drainage. Water that is not lost to evaporation, transpiration by trees and mountain vegetation, or sublimation of snow will either flow overland to mountain streams or will infiltrate fractures in the bedrock. Water that infiltrates bedrock will eventually either flow back into mountain streams or recharge basin-fill sediments along the mountain front.
As the mountain streams flow onto the valley floor, they commonly lose flow to infiltration into basin-fill sediments, thereby recharging basin-fill aquifers. Diversion of streamflow for irrigation essentially spreads water over a larger area, further increasing recharge to the basin-fill aquifers.

Sediments along the east side of the valley are also recharged by the diversion of irrigation water from surface-water sources outside their natural drainage area. The Bitterroot Irrigation District Canal transports water to most of the eastern benches from Lake Como, which is located about 4 mi northwest of Darby. The canal facilitates a net transfer of about 70,000 to 75,000 acre- $\mathrm{ft} / \mathrm{yr}$ of water from the west side of the valley to the eastern benches (Gary Shatzer, Bitterroot Irrigation District, oral commun., 1998). The Bitterroot Irrigation Canal supplies about 7,500 acre-ft/yr of water to the eastern upgradient end of the Hamilton Heights area (Gary Shatzer, written commun., 1998). The Republican and Hedge Ditches supply about 4,400 acre-ft/yr of water diverted from the Bitterroot River to the western downgradient one-third of the Hamilton Heights area (Barry Persson, Daly Ditches Irrigation District, written commun., 1998).

The largest component of discharge from basinfill aquifers is most likely seepage to streams and springs--primarily in lower altitude, downgradient parts of bench areas and along the flood plain of the Bitterroot River. Evapotranspiration from these discharge areas is probably the second largest component of discharge during the growing season. Withdrawals by wells, primarily domestic, is also a discharge component from basin-fill aquifers, although much of the water is returned to aquifers through septic systems.

Water-level contours in the Eightmile area (fig. 8) display several features pertinent to recharge and 


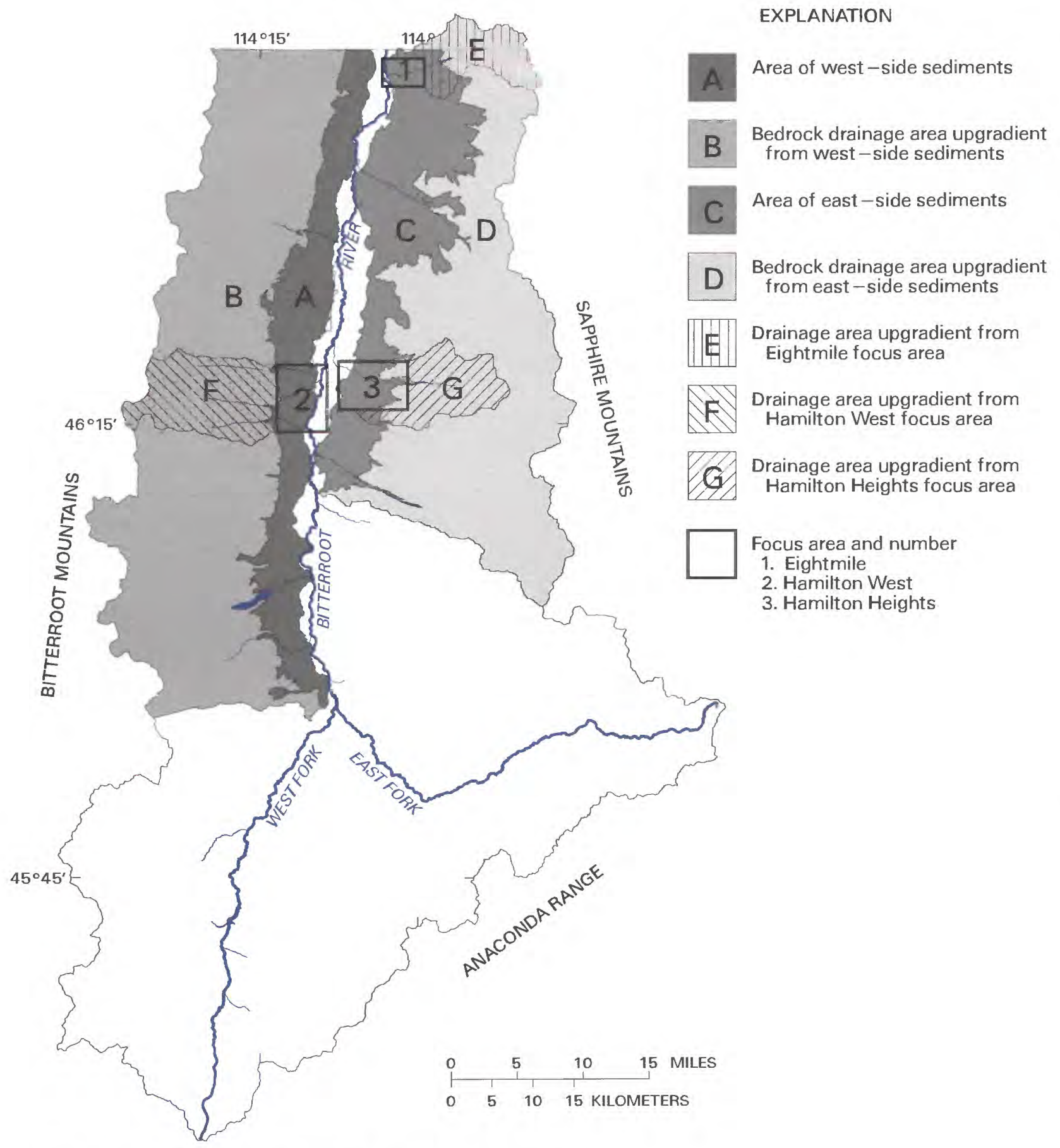

U.S. Geological Survey digital data, 1:100,000, 1983. Albers Equal Area

Conic Projection Standard parallels $44^{\circ} 00^{\prime}$, and $48^{\circ} 00^{\prime}$, central meridian $-114^{\circ} 00^{\prime}$.

Figure 11. Location of sediments, focus areas, and drainage areas upgradient from sediment and focus areas. 
discharge in that area. The downgradient bulge (convex westward) in the $3,250,3,275$, and $3,300 \mathrm{ft}$ contours near Eightmile Creek indicates that the creek is losing water to the underlying aquifer and thereby creating a ground-water mound in that area. Also, the orientation of the water-level contours near the northern and eastern boundaries of the area indicate a direction of ground-water flow from the hills north and east of the area toward the southwest, thereby providing subsurface recharge to the alluvial-fan deposits underlying the Eightmile area. Lastly, the altitude of water levels in the northeast part of the area, where shallow water-yielding zones are absent (fig. 8) and wells are completed in a deep, confined aquifer, are on average more than $100 \mathrm{ft}$ deeper than water levels in nearby wells completed in the shallower aquifer. The water-level altitude in these deep wells is nearly the same as the altitude of the Bitterroot River 2 miles to the west indicating that the direction of ground-water flow in the deep aquifer may not be to the west as it is in the shallower aquifer. This study could not determine from the available data whether the deep aquifer is actually a discontinuous gravel lens that does not discharge to the Bitterroot River or represents a gravel layer that extends under the hills north of the Eightmile area and allows ground water to flow to the northwest and eventually discharge to the Bitterroot River north and downgradient from the study area.

Water-level contours in the Hamilton West area are strongly affected by topography (fig. 9). The three major streams--Mill Creek, Blodgett Creek, and Canyon Creek--are all deeply incised into the basin-fill deposits as they emanate from the mountain front. Water-level contours indicate a general direction of ground-water flow from the mountain front eastward toward the Bitterroot River. Locally the direction of ground-water flow is toward the incised streams, indicating that these streams do not directly recharge the adjacent alluvial-fan deposits. The alluvial-fan deposits are most likely recharged by smaller streams emanating from the mountain front, flow from the major streams diverted for irrigation, subsurface inflow from the mountain bedrock, and precipitation and snowmelt directly on the fan deposits.

Water-level contours in the Hamilton Heights area are also strongly affected by topography (fig. 10). The contours indicate a general direction of groundwater flow from the high benches along the mountain front westward toward the Bitterroot River. Locally the direction of ground-water flow is toward the incised channels of Coalpit, Willow, and Cow Creeks, indicating that these streams do not directly recharge the nearsurface Tertiary sediments underlying the benches.

Recharge to the benches is most likely from irrigation water derived from the Bitterroot Irrigation District Canal and the Republican and Hedge Ditches, and from subsurface inflow from the mountain bedrock.

Although snowmelt on the benches may at times contribute a minor amount of recharge, precipitation during the growing season is probably insufficient to exceed evapotranspiration and the soil-moisture deficit.

\section{Ground-Water Quality}

Water samples were collected from 240 wells in the study area for onsite determination of specific conductance and temperature (table 4 in the Supplemental Data section at the back of this report). Water samples also were collected from 239 wells (fig. 5) in accordance with guidelines described by Knapton (1985) and analyzed in the laboratory for sulfate, chloride, and nitrate concentration. Of these wells, 63 were in the Eightmile area, 60 were in the Hamilton West area, 51 were in the Hamilton Heights area, and the remaining 65 were distributed in other parts of the study area. Results of these analyses are presented in table 6 in the Supplemental Data section at the back of this report. Values and statistics presented in the remainder of this section pertain to the samples collected during this study and do not include data in table 6 that were collected by MBMG or previous USGS investigations.

Specific conductance is a measure of the ability of water to transmit an electric current, which is related to the concentration and electrical charge of ions present in the water. In natural waters, specific conductance typically is proportional to the dissolved-solids concentration of the water--the larger the dissolved-solids concentration, the larger the specific conductance. The median ratio of specific conductance to dissolvedsolids concentration for 62 analyses in table 6 is 1.5:1. The distribution of specific-conductance values for ground water in various locations in the study area is shown in figure 12. The median specific-conductance value for water from all 240 wells measured was 246 $\mu \mathrm{S} / \mathrm{cm}$. The highest specific-conductance value measured in the study area was $864 \mu \mathrm{S} / \mathrm{cm} ; 54$ samples had 


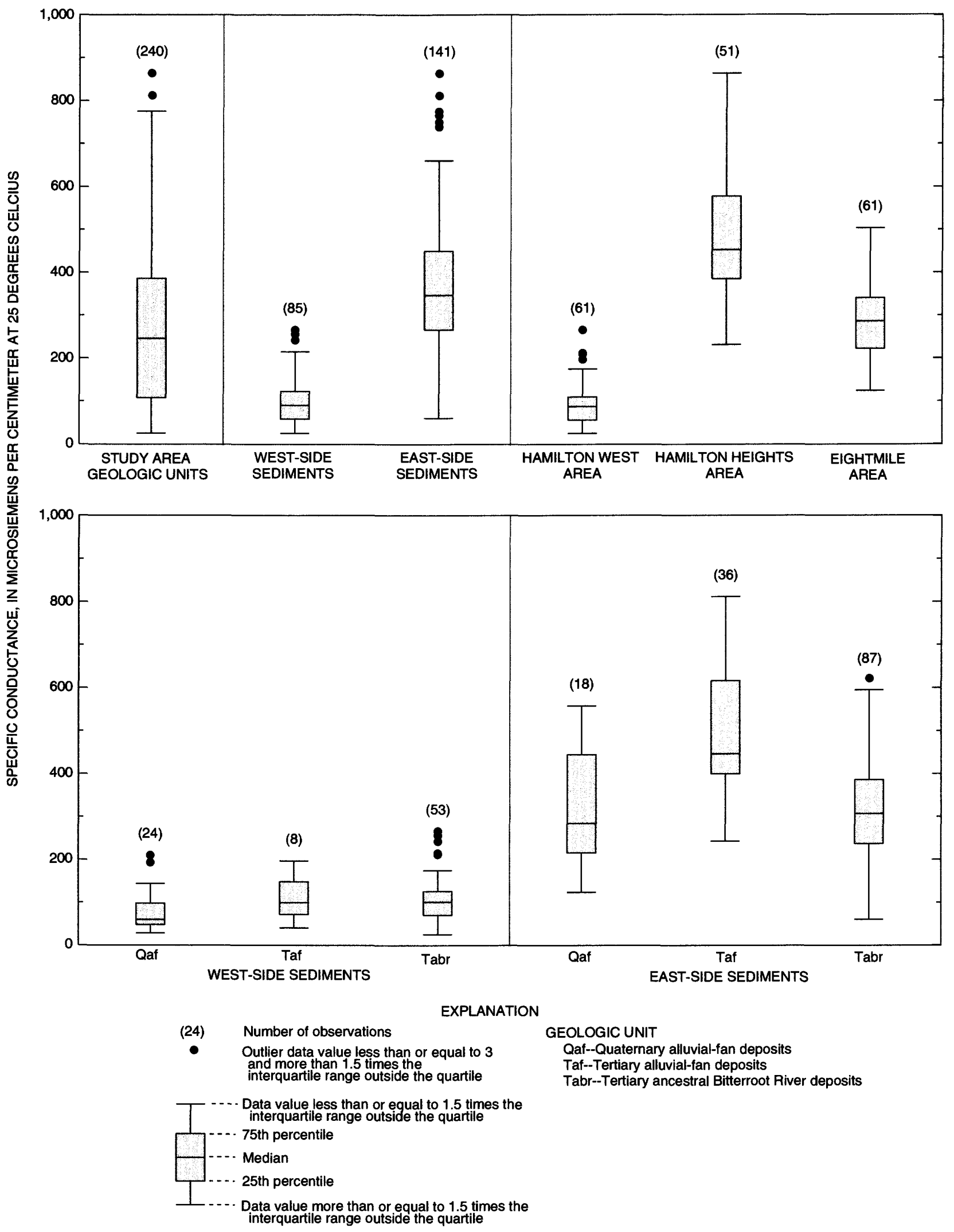

Figure 12. Specific conductance in well water grouped by location and geologic unit. 
specific-conductance values less than $100 \mu \mathrm{S} / \mathrm{cm}$. The median specific-conductance value obtained from water samples from the 85 wells completed in westside sediments was $90 \mu \mathrm{S} / \mathrm{cm}$ and from the 141 wells completed in east-side sediments was $347 \mu \mathrm{S} / \mathrm{cm}$. Thus, the median specific-conductance value for water from wells completed in east-side sediments was almost 4 times the median value for west-side sediments.

The difference in the median specific-conductance values between west-side and east-side sediments is also reflected in the three focus areas (fig. 12). The median specific-conductance value obtained from water in 61 wells in the Hamilton West area was 87 $\mu \mathrm{S} / \mathrm{cm}$--almost identical to the median specific-conductance value obtained from water in all wells completed in west-side sediments. In contrast, the median specific-conductance values obtained from water in 51 wells in the Hamilton Heights area and 61 wells in the Eightmile area--both of which are located on east-side sediments--were 453 and $286 \mu \mathrm{S} / \mathrm{cm}$, respectively.

The range of specific-conductance values for water samples from wells completed in selected geologic units in the study area is also shown in figure 12. The limited number of measurements from water in wells completed in Quaternary alluvium and terraces (3), Quaternary glacial till (1), and Tertiary through Middle Proterozoic bedrock (5) are too small to be statistically significant and are not shown. As shown in figure 12, the specific conductance of ground water is more dependent on which side of the valley the well is located than on the geologic unit in which the well is completed. When each side of the valley is considered separately, the median specific-conductance value for water from wells completed in Tertiary alluvial-fan deposits is slightly larger than the median specificconductance values obtained from water in wells completed in the other two geologic units. The slightly larger specific-conductance values for Tertiary alluvial-fan deposits could be the result of the geochemical characteristics of the sediments, but more probably is due to the smaller permeability of that unit, which thereby limits recharge and its diluting effects. Likewise, the difference in median specific-conductance concentration in water from wells completed in Tertiary alluvial-fan deposits on the east versus the west side of the valley could in part be due to the different geochemical characteristics of the source rock for the sediments but more probably is due to the more limited quantity of precipitation and therefore recharge available on the east versus the west side of the valley.

The concentration of nitrate can be used as an indicator of the effects of human activities on water quality. Except in rare instances, nitrate is not available as a soluble compound in rocks and minerals. Nitrate concentrations in natural waters typically are less than $2 \mathrm{mg} / \mathrm{L}$ (Mueller and others, 1995). Nitrate concentrations that exceed background levels commonly are due to human activities such as sewage disposal and fertilizer application.

Large concentrations of nitrate in ground water are cause for concern. Studies have shown that infants can be seriously harmed, sometimes fatally, by continual ingestion of water containing more than $10 \mathrm{mg} / \mathrm{L}$ of nitrate, expressed as elemental nitrogen (National Academy of Sciences and National Academy of Engineering, 1974). The U.S. Environmental Protection Agency (1996) Primary Drinking-Water Regulations specify a Maximum Contaminant Level (MCL) of 10 $\mathrm{mg} / \mathrm{L}$ for nitrate (as nitrogen) in public drinking-water supplies. Large concentrations of nitrate also can be indicative of other undesirable contaminants, which may include fertilizers, pesticides, or pathogenic bacteria and viruses from sewage.

The median nitrate concentration for the 239 wells sampled during this study was $0.63 \mathrm{mg} / \mathrm{L}$ (fig. 13). Water from 20 wells sampled during this study had nitrate concentrations exceeding $3 \mathrm{mg} / \mathrm{L}$. The largest nitrate concentration sampled in the study area was $5.9 \mathrm{mg} / \mathrm{L} ; 57$ samples had nitrate concentrations below the minimum reporting level of $0.15 \mathrm{mg} / \mathrm{L}$. The median nitrate concentration for samples collected from the 83 wells completed in west-side sediments was $0.17 \mathrm{mg} / \mathrm{L}$. The median nitrate concentration for samples collected from the 143 wells completed in east-side sediments was $1.05 \mathrm{mg} / \mathrm{L}$--or about 6 times larger than the median for west-side sediments.

The difference in the median nitrate concentration between west-side and east-side sediments is also reflected in the three focus areas. The median nitrate concentration for samples collected from 60 wells completed in west-side sediments of the Hamilton West area was identical to the median for all samples collected on the west side of the valley, $0.17 \mathrm{mg} / \mathrm{L}$. In contrast, the median nitrate concentrations for 51 wells sampled in the Hamilton Heights area and 63 wells sampled in the Eightmile area--both areas containing 


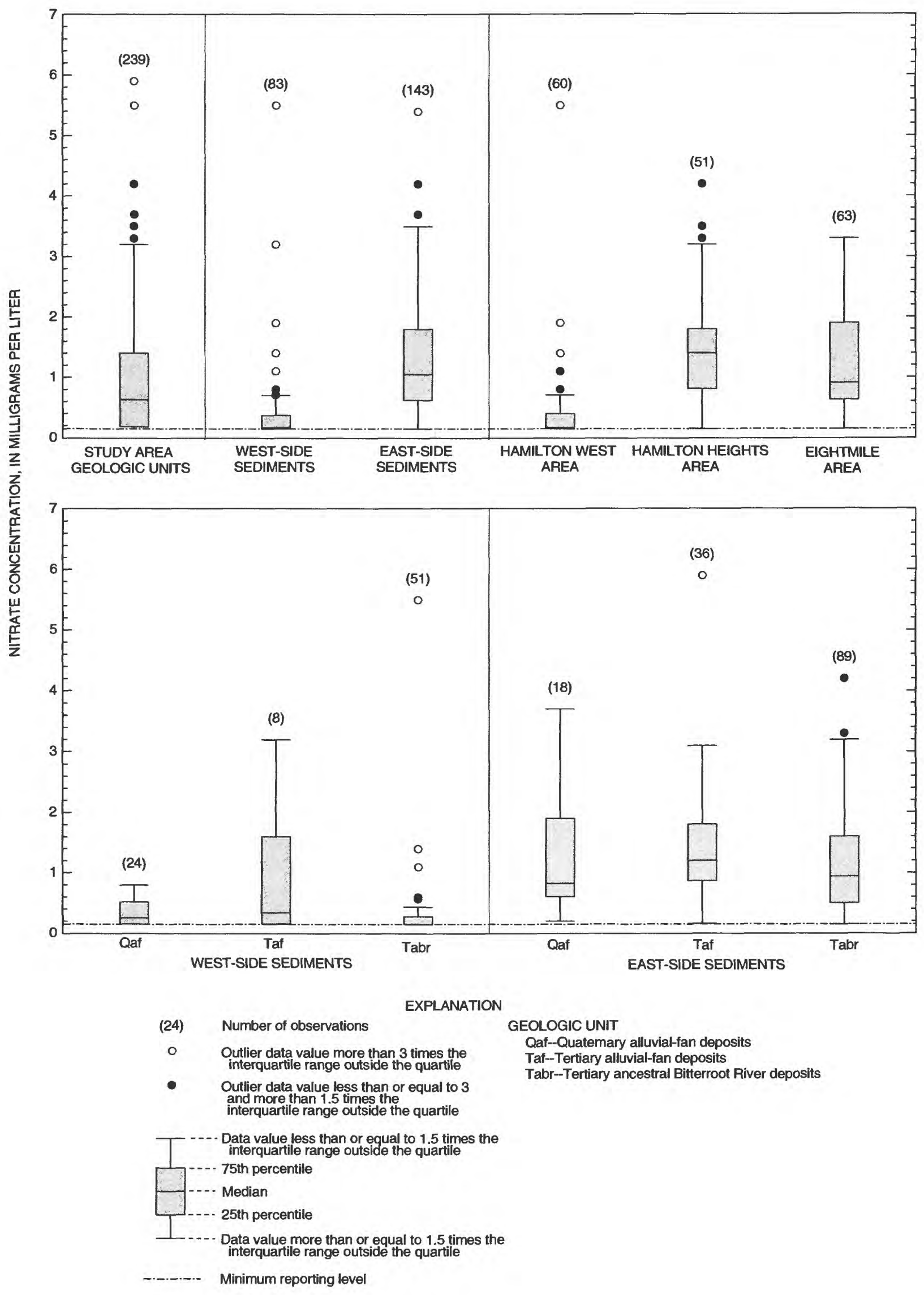

Figure 13. Nitrate concentration in well water grouped by location and geologic unit. 
east-side sediments--were 1.40 and $0.91 \mathrm{mg} / \mathrm{L}$, respectively.

The range of nitrate concentrations in water from wells completed in selected geologic units in the study area is also shown in figure 13. As with specific conductance, the concentration of nitrate in ground water is more dependent on which side of the valley the well is located than on the geologic unit in which the well is completed. Also similar to the distribution of specific conductance, the median nitrate concentration for samples from wells completed in Tertiary alluvial-fan deposits is slightly larger than the median for the other two geologic units when each side of the valley is considered separately. The slightly larger nitrate concentrations in Tertiary alluvial-fan deposits is most likely also due to the lower permeability of that unit, which limits the diluting effects of recharge on nitrate concentration.

The relation between nitrate concentration and shallowest well open interval is presented in figure 14 . Data for 43 wells that lack depth information are not shown. The percentage of wells with nitrate concentrations exceeding $3 \mathrm{mg} / \mathrm{L}$--fifty percent greater than the assumed background concentration for the area--was 5.6 for all 195 wells, 8.0 for the 144 wells with depth to top of open interval less than 125 feet, and 16.2 for the 37 wells with depth to top of open interval less than 40 feet.

The occurrence of larger nitrate concentrations at shallower well depths is probably best understood by the fact that nitrate enters the ground-water system primarily from surface sources and slowly moves deeper into the aquifer if the vertical component of the hydraulic gradient is downward. Nitrate can be removed from an aquifer through the process of denitrification, which involves microbial conversion of nitrate to nitrogen gas in reducing (anoxic) environments--a condition more common in deeper parts of an aquifer. However, data are insufficient to determine the extent of denitrification in the study area. The general relation between nitrate concentration and well depth does not seem to be dependent on sample location in the valley.

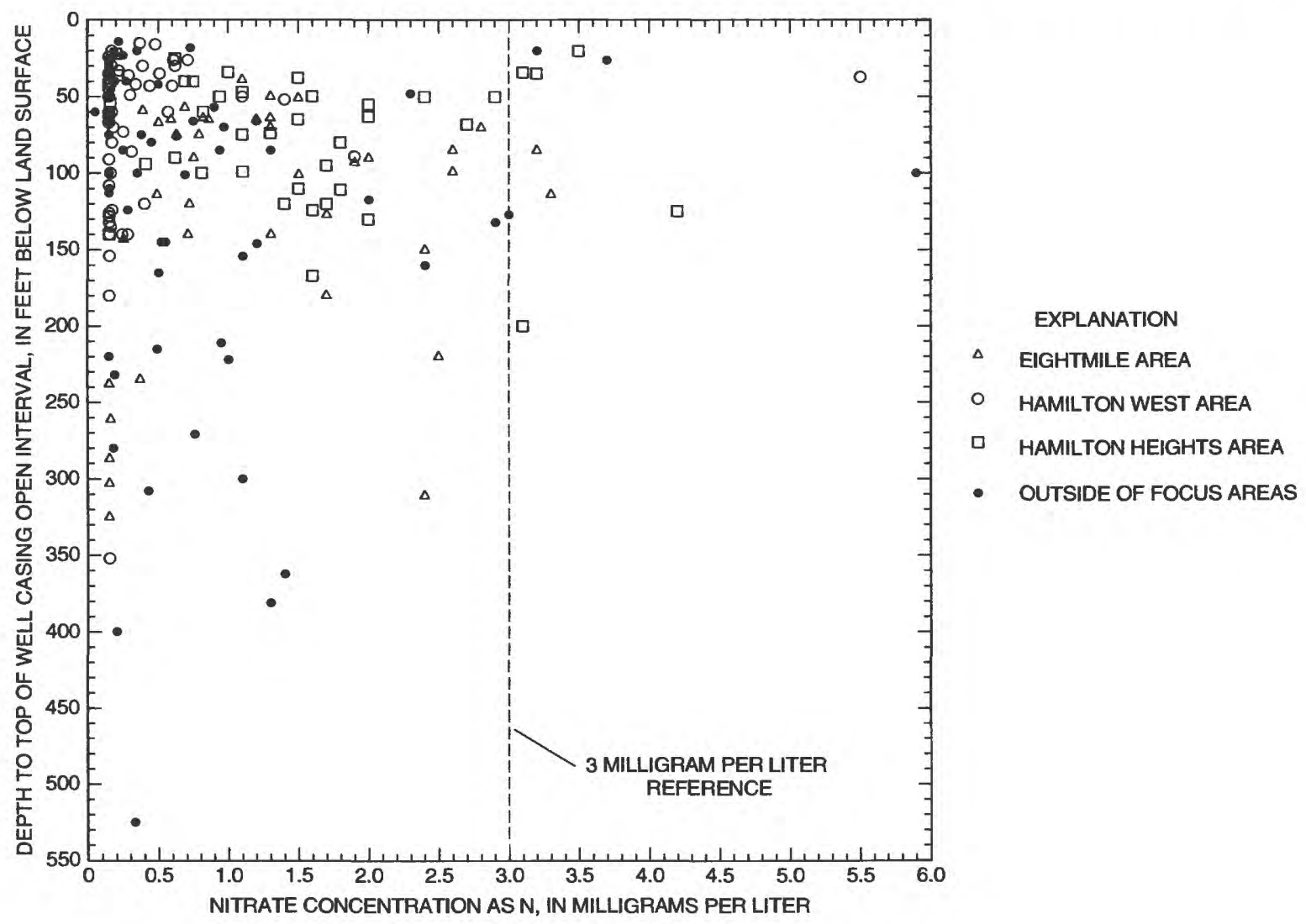

Figure 14. Nitrate concentration in well water versus depth to top of well casing open interval. 
The distribution of nitrate concentrations in water from wells in each of the three focus areas is shown in figures 15-17. To determine the timing and magnitude of any seasonal fluctuation in the concentration of nitrate in ground water, 16 wells were sampled approximately bimonthly from November 1996 through October 1997. The changes in nitrate concentration of samples from the 15 wells located in the three focus areas are shown in figure 18. Of the three areas, samples from the five wells in the Eightmile area show the clearest pattern of nitrate concentration fluctuations with season; the smallest concentrations occur in AprilJune and the largest in January. Whereas the magnitude of change in nitrate concentration in the Hamilton West and Hamilton Heights areas can be as large as in the Eightmile area, samples from the five wells in each of the Hamilton West and Hamilton Heights areas do not show the same pattern as in the Eightmile area.

The precise cause of the seasonal variability in nitrate concentration cannot be determined from the available data. However, it is important to note the seasonal variability when interpreting the data or attempting long-term trend analysis. The nitrate data presented in figures 15-17 are based on samples collected at different times in the 1994, 1995, and 1996 field seasons; therefore, the data contain both seasonal variability and spatial differences. For example, on the basis of August 1994 samples, water from well 10N19W07BAAD01 is shown in figure 15 as having a nitrate concentration of $3.2 \mathrm{mg} / \mathrm{L}$, which is noticeably larger than the nitrate concentrations shown for nearby wells. When the well was resampled in August, 3 years later, the water had a similar nitrate concentration of $3.1 \mathrm{mg} / \mathrm{L}$. However, when the well was sampled in April 1997, the nitrate concentration was $1.9 \mathrm{mg} / \mathrm{L}$. If the data presented for well 10N19W07BAAD01 in figure 15 had by chance been based on an April rather than August sample, the relation of nitrate concentration in nearby wells would probably have been different from that shown.

In addition to the variability caused by actual environmental conditions, uncertainty is introduced during the course of sample collection and laboratory analysis. In an attempt to assess the degree to which these uncertainties are present in the data, 48 blind replicate samples were collected and submitted concurrently from the field along with 391 separate samples collected from the 239 wells. Results are included in table 6. An additional replicate sample listed in table 6
(07N21W13BBAD01) was from a previous study which did not include nitrate. The median difference in nitrate concentration between replicates of 48 samples was $0.01 \mathrm{mg} / \mathrm{L}$. The 5 largest differences in nitrate concentration between replicates were $1.0,0.9,0.5,0.5$, and $0.4 \mathrm{mg} / \mathrm{L}$, and 23 replicates had no difference $(0.0$ $\mathrm{mg} / \mathrm{L})$. The median difference for the 48 replicates was 2 percent, and 33 replicates ( 68 percent of the total) had a 10 percent or smaller difference.

The use of these data in the interpretation of long-term trends should proceed only with a full understanding of the temporal variability and procedural uncertainty presented above. Any attempts at longterm trend analysis of nitrate concentration in the study area should be based on an extensively quality-assured dataset of sufficient temporal and spatial continuity to allow for a statistically significant separation of analytical and seasonal variability from long-term trends in the data.

Additional water samples were collected from 43 wells, 3 streams, 1 irrigation canal, and 1 spring for laboratory analysis of major-ion and trace-element concentrations. Water samples from the 43 wells were also analyzed for radon concentration. The locations of surface-water sites and the one spring are listed in table 2. Major-ion and trace-element concentrations in water samples collected during this and previous studies are presented in tables 6-9 in the Supplemental Data section at the back of this report. The dominant cations and anions in samples from the three focus areas are graphically summarized in figure 19 . On the basis of the data presented, water from wells in all three focus areas is primarily a calcium bicarbonate type. However, water in the Hamilton West and Hamilton Heights areas tends to have a slightly larger percentage of sodium than does water in the Eightmile area, with one sample in the Hamilton West area and two samples in the Hamilton Heights area being classified as sodium bicarbonate type.

The suitability of water for public drinking-water supply is established by the U.S. Environmental Protection Agency Primary and Secondary DrinkingWater Regulations (table 12). National Primary Drinking-Water Regulations are established for contaminants which, if present in drinking water, may cause adverse human health effects. Either an MCL or a treatment technique is specified by these regulations for regulated contaminants. MCL's are health based and 


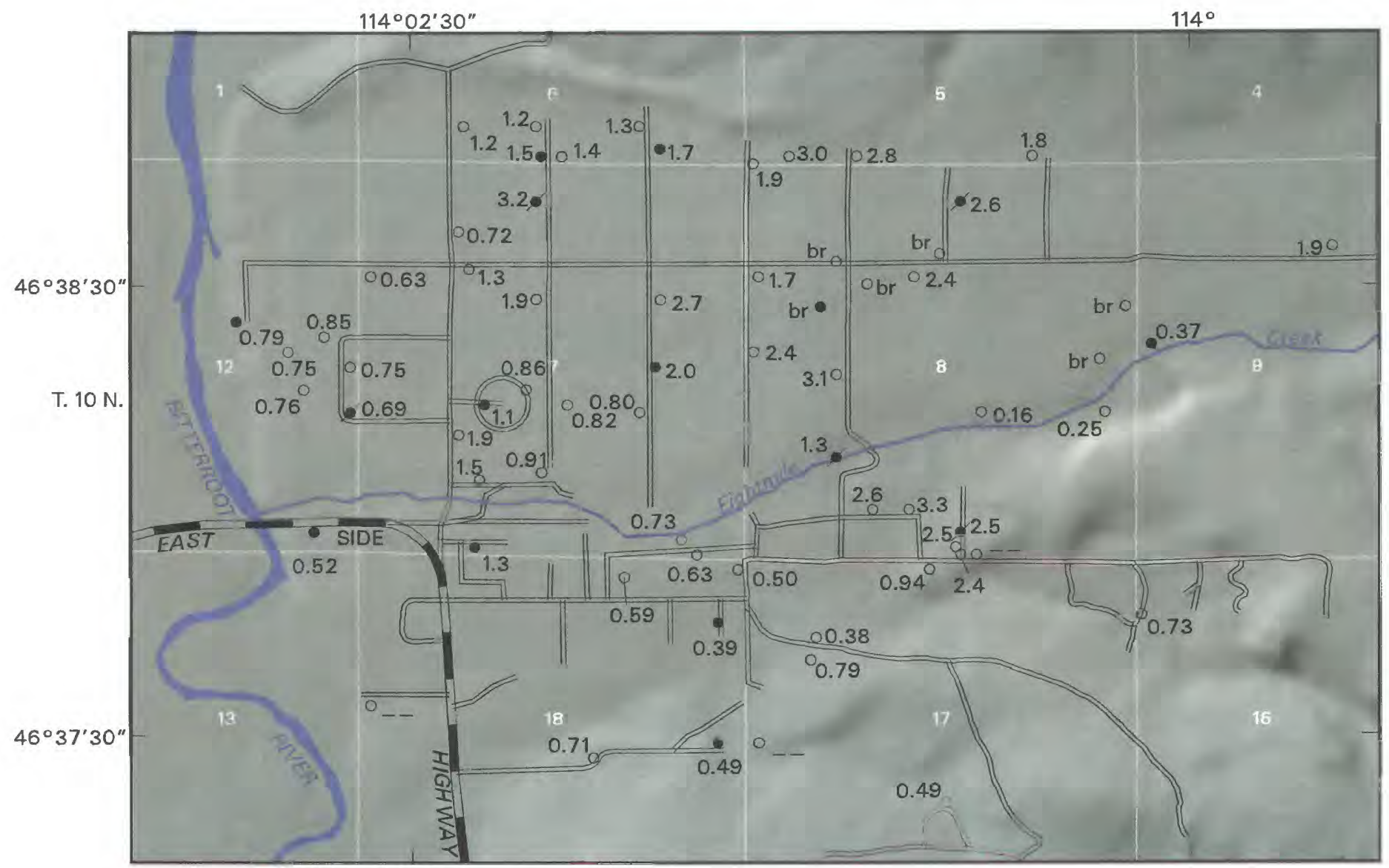

R. 20 W. R. 19 W.

Base from U.S. Geological Survey digital data, 1:24,000, 1979 to present. Albers Equal Area Conic Projection Standard parallels $44^{\circ} 00^{\prime}$, and $48^{\circ} 00^{\prime}$, central meridian $-114^{\circ} 00^{\prime}$.

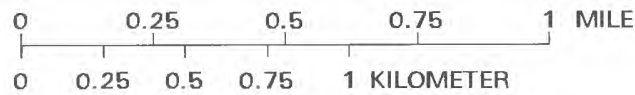

\author{
EXPLANATION \\ INVENTORIED WELL \\ - Well in water-level \\ monitoring network \\ - Well in water-level and \\ nitrate monitoring \\ networks \\ - Well not in monitoring \\ network \\ 0.75 NITRATE CONCENTRATION, \\ IN MILLIGRAMS PER LITER; \\ --, no data; br, below minimum \\ reporting level
}

Figure 15. Distribution of nitrate concentration in well water from the Eightmile area, 1994-96. 



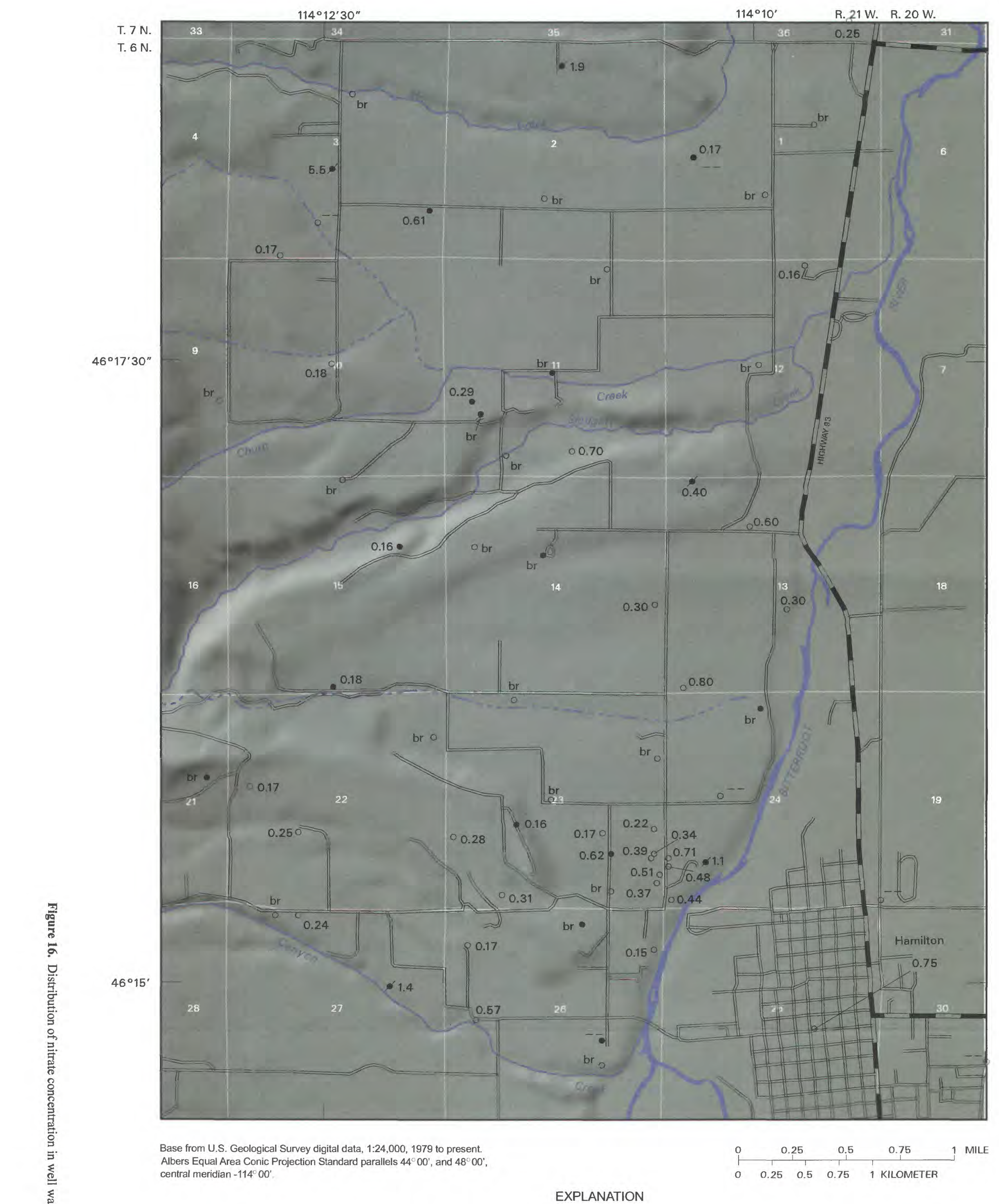

EXPLANATION

INVENTORIED WELL

- Well in water-level

monitoring network

- Well in water-level and

nitrate monitoring

networks

- Well not in monitoring

network

0.75 NITRATE CONCENTRATION,

IN MILLIGRAMS PER LITER;

-, no data; br, below minimum

reporting level 



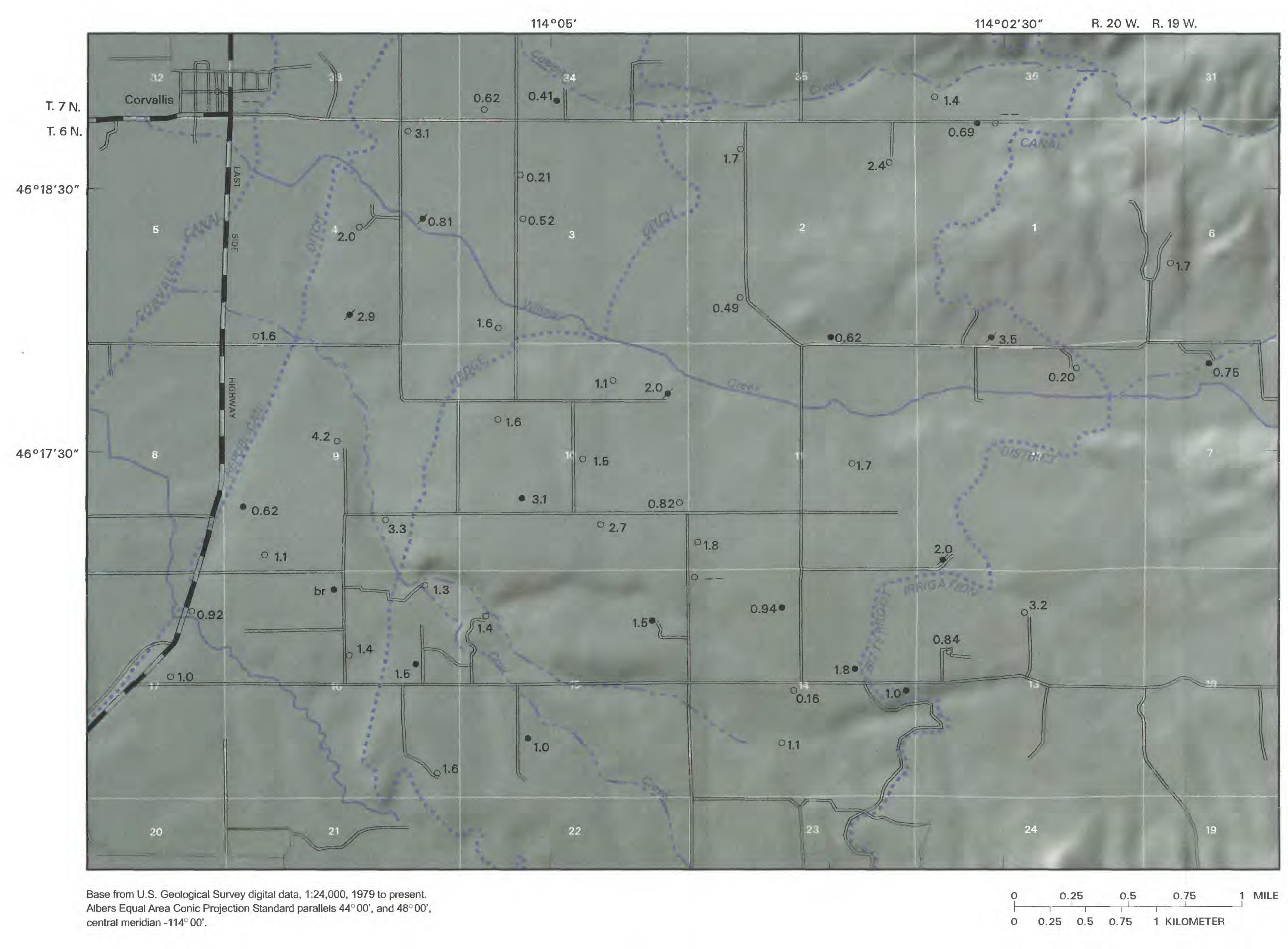

EXPLANATION
INVENTORIED WELL

- Well in water-level

- Well in water-level and

nitrate monitoring

- Well not in monitoring

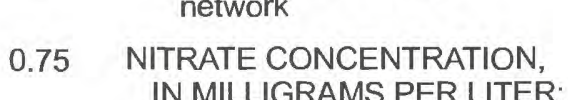

no dara br below minimum

reporting level

Figure 17. Distribution of nitrate concentration in well water from the Hamilton Heights area, 1994-96. 


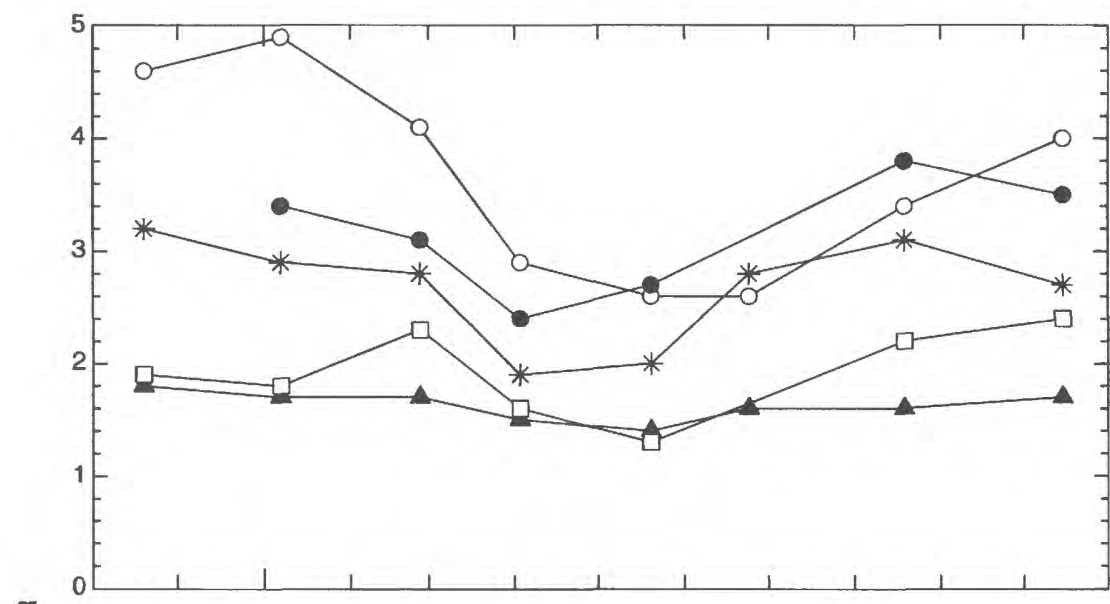

\section{EXPLANATION}

EIGHTMILE AREA

- 10N20W12DADA01

-O- 10N19W08ABBC01

$\rightarrow \square-\quad$ 10N19W08CBDD01

- 10N19W08DCCB01

* 10N19W07BAAD01

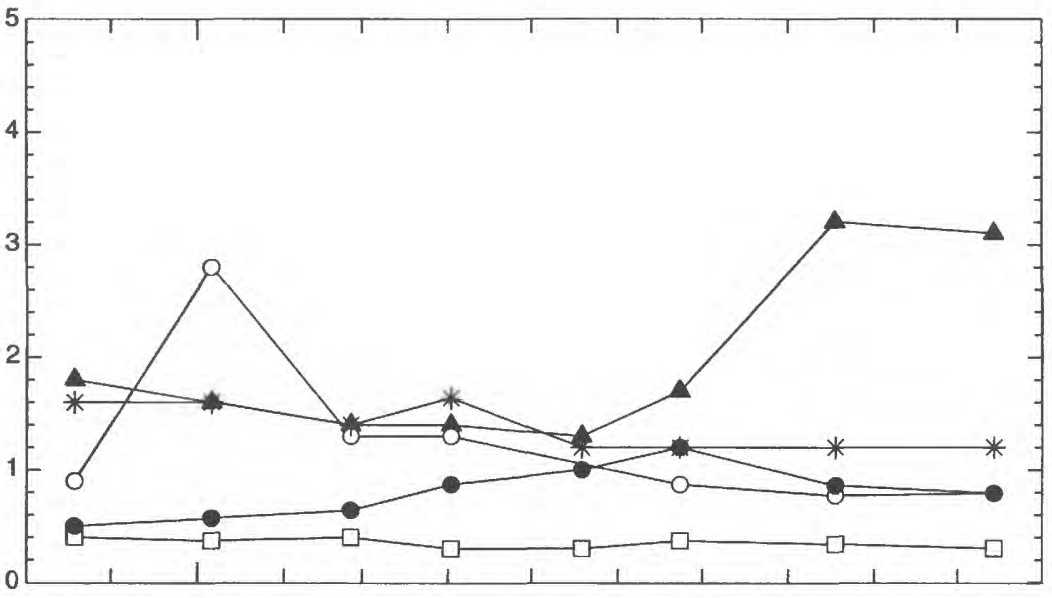

HAMILTON WEST AREA

- 06N21W02ABBD01

-O- O6N21W03CAACO1

$\rightarrow \square-06 N 21 W 13 B B A B 01$

- 06N21W24CCAC01

* 06N21W27ADBC01

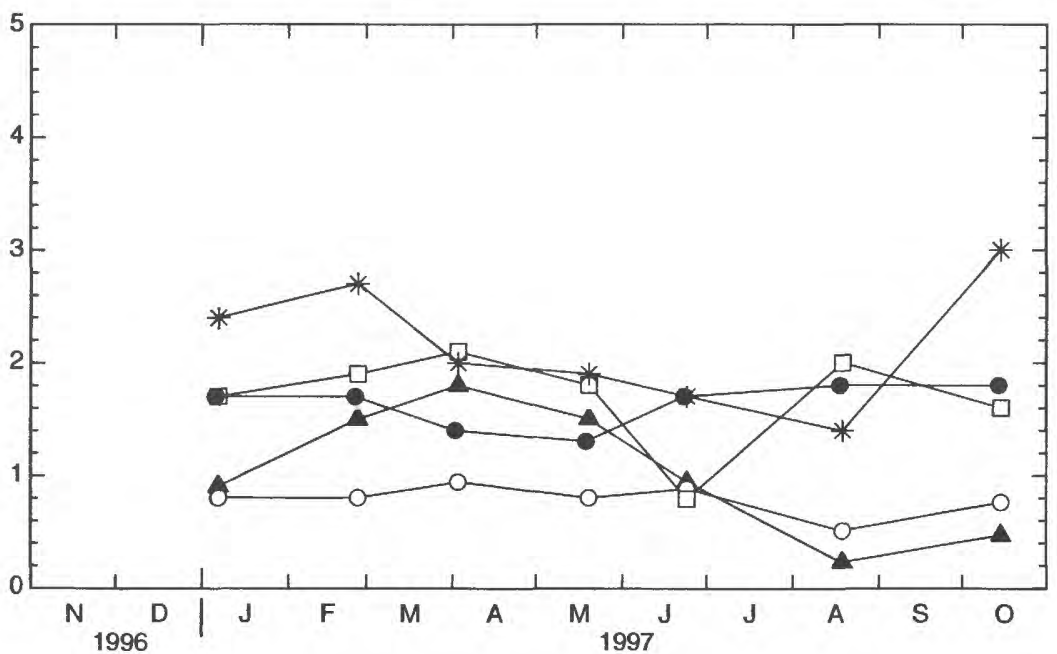

HAMILTON HEIGHTS AREA

- - 06N20W01CDCD01

-O- 06N20W04ADCD01

- $\square-$ O6N20W04DCCB01

- 06N2OW10AADC01

* 06N20W12CCCD01

Figure 18. Monthly variation in nitrate concentration in well water. 


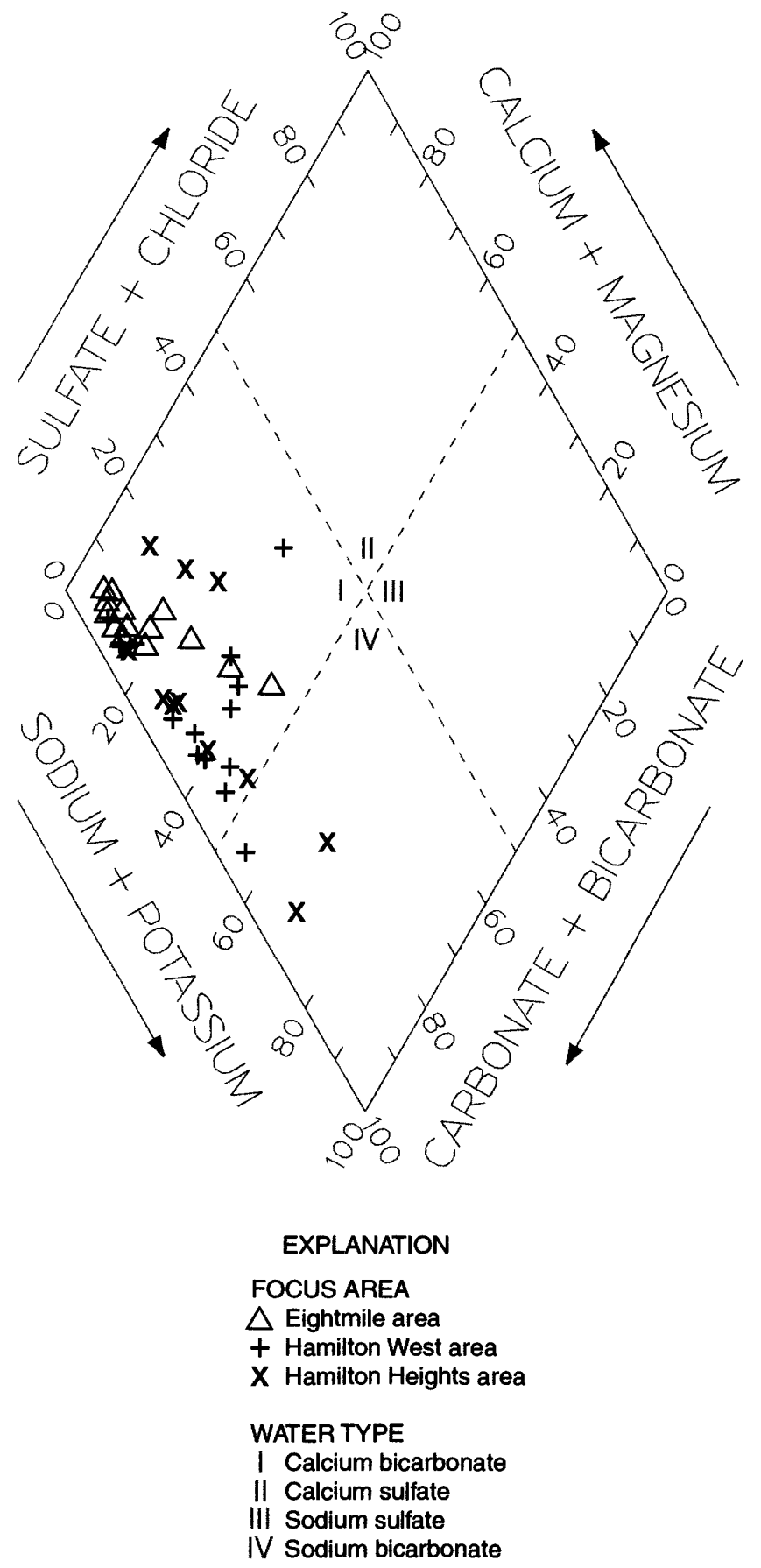

Figure 19. Modified trilinear diagram showing percentages of major ions in well water from the three focus areas. Data were converted from milligrams per liter to millequivalents per liter, then values for each cation and anion were plotted on the diagram as a percentage of total milliequivalents per liter. 
Table 2. Location and description of surface-water sites and one spring (shown in downvalley order)

\begin{tabular}{cl}
\hline Location number & \multicolumn{1}{c}{ Site description } \\
\hline 06N21W20AABB01 & Blodgett Creek on west side of Blodgett Canyon Campground Bridge, about 5 miles west of Hamilton \\
06N20W12AACD01 & Bitterroot Irrigation District Canal where it crosses Willow Creek, about 5 miles southeast of Corvallis \\
06N20W12AACD02 & Willow Creek east of where the Bitterroot Irrigation District Canal crosses, about 5 miles southeast of Corvallis \\
08N20W02ACBD01 & Spring at 373 Pine Hollow Road, about 2 miles southeast of Stevensville \\
10N19W03DCCD01 & Eightmile Creek where Granite Creek Road crosses on northeast side, about 6 miles east of Florence \\
\hline
\end{tabular}

enforceable (U.S. Environmental Protection Agency, 1996). National Secondary Drinking-Water

Regulations are established for contaminants that can adversely affect the odor or appearance of water and result in discontinuation of use of the water. These regulations specify Secondary Maximum Contaminant Levels (SMCLs) that are esthetically based and nonenforceable (U.S. Environmental Protection Agency, 1996).

The major-ion and trace-element concentrations shown in tables 6-9 are all less than the MCL's except for one occurrence of cadmium equal to the MCL of 5 $\mu \mathrm{g} / \mathrm{L}$. One sample has a fluoride concentration larger than the SMCL of $2 \mu \mathrm{g} / \mathrm{L}$, six samples have iron concentrations larger than the SMCL of $300 \mu \mathrm{g} / \mathrm{L}$, and five samples have manganese concentrations larger than the SMCL of $50 \mu \mathrm{g} / \mathrm{L}$.

In an attempt to assess the degree of uncertainty in the major-ion, trace-element, and radon data due to sample collection and laboratory analysis, five blind replicate samples and two field blanks were processed and submitted concurrently from the field. Results of the replicate analyses are included in tables 6 and 7 . Agreement between constituent concentrations in replicate samples generally was good, with several exceptions: one instance of a 13-percent difference in chloride concentration, one instance of a 25 -percent difference in potassium concentration, and one instance of a 58-percent difference in iron concentration and 33-percent difference in manganese concentration at magnitudes near the minimum reporting levels for these constituents. Results of the field-blank analyses are shown in tables 10 and 11 in the Supplemental Data section at the back of this report. All analyzed constituents in field blanks were below the minimum reporting level, except for one instance of potassium concentration at $0.19 \mathrm{mg} / \mathrm{L}$ and silica concentrations of $20 \mathrm{mg} / \mathrm{L}$ in two blanks. The silica present in the blank samples has been recognized previously as being due to contamination by the deionizing filters used to prepare the blank in the laboratory. Silica contamination of well-water samples due to sample preparation is probably minimal and was not of concern for this study.

Radon is a naturally occurring, odorless, tasteless, inert gas formed by the natural radioactive decay of uranium, which is present to some extent in nearly all rocks. Granitic rocks such as those surrounding much of the Bitterroot Valley commonly contain uranium. The presence of radon is a cause for concern because inhalation of its radioactive decay products at sufficiently elevated concentrations is known to cause lung cancer. The average overall world indoor radon concentration in air is about $0.4 \mathrm{pCi} / \mathrm{L}$. However, indications are that average concentrations in the United States are higher (Cothern, 1987). To minimize exposure and possible health risks, the U.S. Environmental Protection Agency (1992) recommends that the average radon concentration in indoor air not exceed 4.0 $\mathrm{pCi} / \mathrm{L}$.

The primary source of radon in indoor air is the soil; radon from the soil can infiltrate houses through cracks, vents, joints, or other openings in basement floors and walls. The next largest source of radon in indoor air is from degassing from well water used for household purposes. A radon concentration of 10,000 $\mathrm{pCi} / \mathrm{L}$ in water is estimated to produce a $1 \mathrm{pCi} / \mathrm{L}$ increase in radon concentration in air, given the typical usage and household characteristics in the United States (Cothern, 1987). To keep radon concentrations in indoor air to a minimum, the U.S. Environmental Protection Agency (1996) established an MCL for radon in water of $300 \mathrm{pCi} / \mathrm{L}$ but subsequently withdrew the regulation in July 1997 at the direction of the U.S. Congress (U.S. Environmental Protection Agency, 1997). Congress has directed the U.S. Environmental Protection Agency to propose new regulations for 
radon-222 by August 1999 and promulgate a final regulation by August 2000 .

The 43 radon concentrations shown in table 7 range from 150 to $3,700 \mathrm{pCi} / \mathrm{L}$ and have a median of $810 \mathrm{pCi} / \mathrm{L}$. By focus area, the median radon concentration was $710 \mathrm{pCi} / \mathrm{L}$ for 15 samples in the Eightmile area, was $1,205 \mathrm{pCi} / \mathrm{L}$ for 10 samples in the Hamilton West area, and was $215 \mathrm{pCi} / \mathrm{L}$ for 8 samples in the Hamilton Heights area. Effective treatments for the removal of radon from ground water are available (U.S. Environmental Protection Agency, 1992).

\section{AQUIFER SENSITIVITY}

Water contamination can include any chemical, physical, or biological constituent, compound, or characteristic that is considered to be undesirable for an intended use of the water. Dissolved contaminants generally are transported in the direction of ground-water flow, although some transport can occur by diffusion. However, contaminants that do not dissolve in water can move in directions that differ from the direction of ground-water flow, although some transport can occur by diffusion. For example, compounds that are more dense than water can move downward through the aquifer, even in areas where the vertical component of hydraulic gradient and vertical component of flow are upward. Compounds that are less dense than water can mound on the water table and move in directions other than the direction of ground-water flow. The contaminants considered in this study generally are dissolved chemical constituents or compounds.

Aquifers in many parts of the study area are relatively susceptible to potential contamination from surface or near-surface sources because the coarse-grained character of the near-surface sediments could allow contaminants to readily infiltrate. In these areas, the underlying aquifers are commonly unconfined and can be contaminated by septic-system overflow or failure, fuel from surface spills or leaking underground storage tanks and pipe lines, leachate from landfills and sewage lagoons, agricultural and residential chemicals, and other sources of inorganic and organic compounds. For example, part of the alluvial aquifer in the northern part of the study area has been affected by leachate from a landfill, resulting in contamination of water in the area of several downgradient wells (Ravalli County Sanitarian's Office, written commun., 1998). Other potential sources of contamination include urban storm-water runoff, effluent from municipal waste water disposal, and dry sumps. Most of the documented and potential sources of contamination to the aquifers are point specific and affect only relatively localized areas. This study focused on characterizing the overall water quality in the Bitterroot Valley and did not address known point-source water-quality problems.

Rapid and continued population growth and the resulting widespread residential development probably represent the greatest potential for change to water quality in the study area. As shown in figure 20, population growth in Ravalli County has been greatest since 1990 , and most of this growth has occurred within the rural parts of the study area. The nitrate concentration data collected by this study can, with certain limitations, serve as a surrogate to measure human effects on the aquifers underlying the study area.

Although rural septic input, residential fertilizers, and domestic animal waste can all contribute to nitrate loading of an aquifer and may be expected to increase with increased rural population, most of the study area currently undergoing new residential development was previously used for agriculture. Agricultural activity also can be a source of nitrate loading, primarily from inorganic fertilizers and animal manure. Therefore, the nitrate-concentration data presented in this report probably reflect nitrate loading from multiple sources. Analytical techniques using nitrogen isotopes can potentially differentiate between animal waste--which includes septic effluent--and inorganic fertilizer sources but employment of those analytical techniques was beyond the resources available for this study.

Although the dominant source of nitrate loading cannot be uniquely identified at most sample sites, the relatively small nitrate concentrations in the 239 wells sampled for this study indicate that the total nitrate load to the sampled aquifers has not resulted in nitrate concentrations that exceed the U.S. Environmental Protection Agency (1996) MCL to date. Localized areas of some aquifers might have nitrate concentrations larger than those reported in this study, but no areas were identified from the data.

Two qualifications are worth noting with respect to the relation between the relatively small nitrate concentrations presented in this report and the potential water-quality effects resulting from increased popula- 


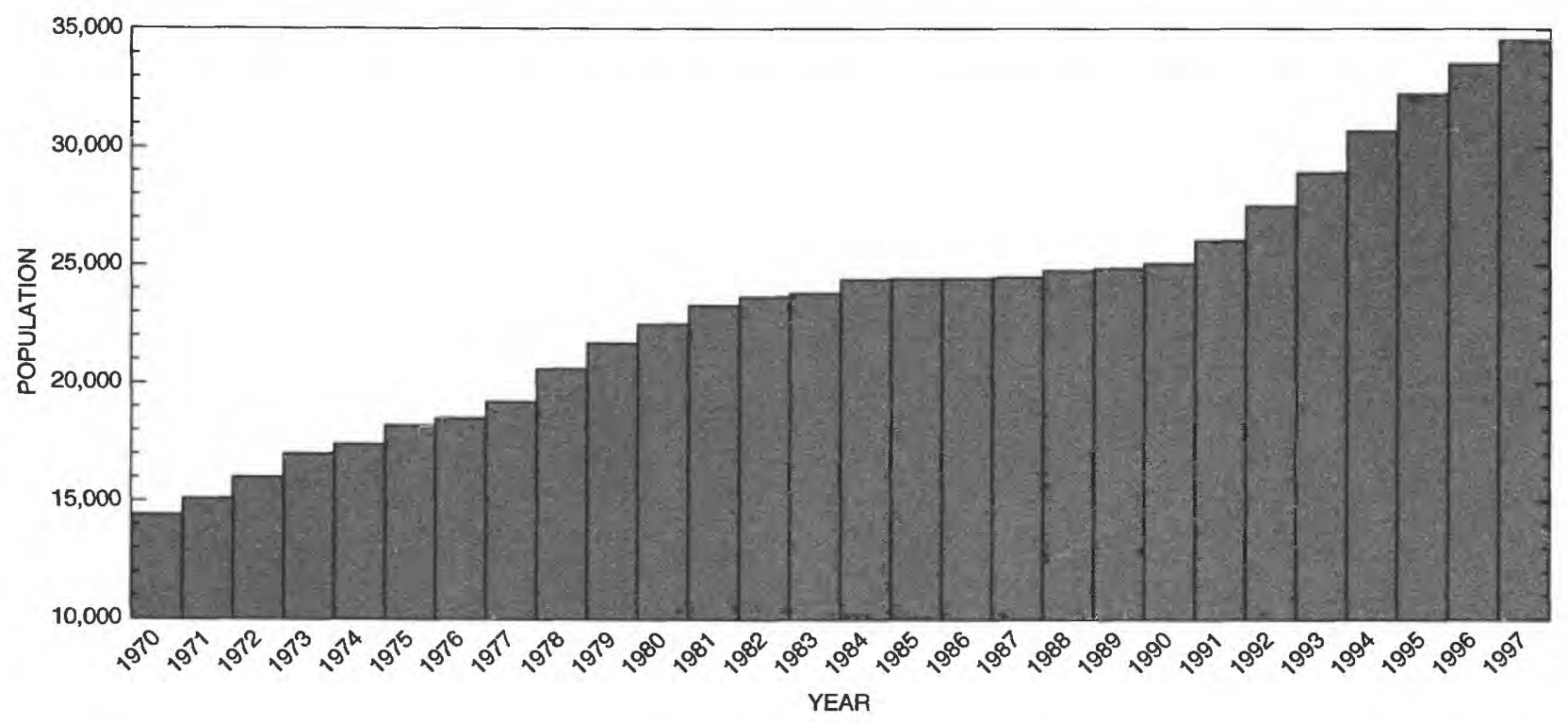

Figure 20. Population of Ravalli County by year, 1970-97. Numbers are estimates, except for 1970, 1980, and 1990, which are from the decennial census. Data from U.S. Bureau of the Census (issued annually; issued decennially).

tion and development in the study area. Whereas the nitrate data do not indicate any widespread problems at the time the samples were collected, the lag between the time when a change in land use causes a change in nitrate loading to an area and the time when any resulting change in nitrate concentration can be detected at a downgradient sample site cannot be determined from the available data. Given this uncertainty, the samples collected during this study might be the result of the nitrate loading patterns dominant many years prior to sample collection. If this were true, changes in nitrate loading patterns due to present land use changes might not be detectable in samples until some time in the future.

The second qualification is that the response of the aquifers to nitrate loading, as measured by nitrate concentration in well water, is not necessarily directly proportional to the total nitrate load to the aquifer. As a hypothetical example, if nitrogen uptake by plants in a shallow ground-water area just downgradient from a small residential subdivision using septic systems is capable of removing just enough nitrate to maintain a concentration in ground water of $0.5 \mathrm{mg} / \mathrm{L}$, doubling the size of the subdivision and the resulting nitrate load could potentially more than double the downgradient nitrate concentration if the capacity of the plants to remove nitrate were exceeded by the additional load- ing. A "threshold effect" similar to the one described could apply to other chemical constituents and buffering mechanisms as well.

Although the specific conductance and nitrate concentrations in ground water sampled in the study area were generally small, differences were significant between different parts of the study area, which is pertinent to the sensitivity of the aquifers in those areas to contamination. The Hamilton West area had the smallest median values for specific conductance and nitrate concentration of the three focus areas even though it had the largest population, and presumably septic-tank density, indicated by the density of wells (table 3 ).

Conversely, the Hamilton Heights area had the largest median values for specific conductance and nitrate concentration and the smallest population density indicated by the density of wells. Specific conductance and nitrate concentration in the Eightmile area fell in between these two extremes.

The sensitivity of the focus-area aquifers to nitrate loading is most strongly related to the total ground-water recharge to each area--the greater the recharge (and hence dilution), the less sensitive is the aquifer (as measured by nitrate concentration in water from wells) to a given nitrate load. The quantity of ground-water recharge in the three areas is primarily controlled by two factors--the average annual precipi- 
Table 3. Summary of specific conductance, nitrate concentration, well density, average precipitation, and percentage of wells completed in Tertiary alluvial-fan deposits in the three focus areas. Table ordered by increasing values of specific conductance and nitrate concentration

[Abbreviations: $\mu \mathrm{S} / \mathrm{cm}$, microsiemens per centimeter at 25 degrees Celsius; $\mathrm{mg} / \mathrm{L}$, milligrams per liter]

\begin{tabular}{lccccc}
\hline Focus area & $\begin{array}{c}\text { Median specific } \\
\text { conductance in } \\
(\mu \mathbf{S} / \mathbf{c m})\end{array}$ & $\begin{array}{c}\text { Median nitrate } \\
\text { concentration } \\
(\mathbf{m g} / \mathbf{L})\end{array}$ & $\begin{array}{c}\text { Average number } \\
\text { of wells per square } \\
\text { mile }\end{array}$ & $\begin{array}{c}\text { Average } \\
\text { precipitation } \\
\text { (inches) }\end{array}$ & $\begin{array}{c}\text { Percentage of } \\
\text { sampled wells } \\
\text { completed in } \\
\text { Tertiary alluvial- } \\
\text { fan deposits }\end{array}$ \\
\hline Hamilton West & 87 & 0.17 & 62 & 41.28 & 6.3 \\
Eightmile & 286 & .91 & 51 & 19.68 & 0 \\
Hamilton Heights & 453 & 1.40 & 31 & 21.24 & 43.3 \\
\hline
\end{tabular}

tation and, to a lesser degree, the percentage of Tertiary alluvial-fan deposits in the respective area.

The difference in average annual precipitation in and upgradient of the three areas and the resulting quantity of water available for recharge is most probably the cause of the substantially smaller values for specific conductance and nitrate concentration in the Hamilton West area as compared to the Eightmile and Hamilton Heights areas (table 3). The drainage area of the Hamilton West area receives about twice the annual precipitation of the other two focus areas. Thus, the larger quantity of water available for recharge in the Hamilton West area probably has a diluting effect on the specific conductance and nitrate concentration.

The extensive Tertiary alluvial-fan deposits in the Hamilton Heights area are probably the cause of the larger specific conductance and nitrate concentrations as compared to the Eightmile area (table 3). Because the Tertiary alluvial-fan deposits are generally less permeable, recharge to the Hamilton Heights area is more limited than in the Eightmile area. The smaller quantity of recharge to the Tertiary alluvial-fan deposits limits dilution in those areas.

Although aquifers in west-side sediments have smaller values for specific conductance and nitrate concentration than those on the east side of the valley, the west-side sediments might contribute more constituent loading to the Bitterroot River than the east-side sediments. The total constituent load to a system is a function of the concentration of a constituent in the source water multiplied by the total volume of that water that recharges the system. Even though constituent concentrations in ground water on the west side of the valley are generally much smaller than those on the east side, data presented in this report indicate that the rate of ground-water flow through the west-side sediments and eventually discharging to the Bitterroot River is considerably larger than that of the east side. However, data of sufficient precision to accurately determine the extent of loading in the study area are not available.

\section{SUMMARY AND CONCLUSIONS}

The Bitterroot Valley is located in Ravalli County of western Montana. During the early 1990s, the Ravalli County estimated population increased at the fastest rate in the State, with much of the increase occurring outside of established cities and towns. The potential for degradation of local aquifers due to continued growth is large. This study was initiated to establish a ground-water monitoring network, implement a geographically indexed computer-based data framework, define ground-water flow paths, describe ground-water recharge sources and discharge areas, characterize any potential sources of ground-water degradation, and identify any areas with existing degradation.

The Bitterroot Valley is situated in a 7-mi wide by 52-mi long north-trending intermontane basin in the Northern Rocky Mountains physiographic province. The Bitterroot Valley contains two principal topographic features and related aquifers--the flood plain of the Bitterroot River, which extends the length of the valley, and the adjacent extensive high benches along the east and west sides of the valley. 
The major surface-water artery of the Bitterroot Valley is the Bitterroot River, which originates in the southern Bitterroot Mountains and the Anaconda Range and flows northward through the basin to its confluence with the Clark Fork about $15 \mathrm{mi}$ north of the study area. About 4 times as many tributaries join the river from the Bitterroot Mountains on the west as from the drier Sapphire Mountains on the east.

To provide a more in-depth investigation of selected areas of the valley, three focus areas were selected on the basis of physiography, geology, climate, effect of irrigation, and development pressure. The three areas are referred to as the Eightmile, Hamilton West, and Hamilton Heights areas.

The Bitterroot Valley is situated in a structural basin most probably formed by crustal extension during the middle Eocene Epoch. Intrusive, metasedimentary, metamorphic, and volcanic rocks border the valley and Tertiary sediments overlie bedrock and crop out on the eastern, and to a lesser extent, western benches. Tertiary sediments also occur at depth beneath the benches, beneath a veneer of Quaternary alluvium along the Bitterroot River flood plain, and beneath Quaternary alluvial fans along the floors of tributary valleys. These unconsolidated to semiconsolidated Tertiary deposits are composed of gravel, sand, silt, and clay that occur as two distinct geological units: the ancestral Bitterroot River deposits and the Sixmile Creek Formation.

The ancestral Bitterroot River deposits--the lower of the two Tertiary units in the basin--are composed of rocks derived from the entire drainage basin, with several distinctive clast types indicating transport from the far southwestern end of the basin and possibly even beyond. The ancestral Bitterroot River deposits most likely result from deposition by a northward through-flowing river of regional scale during the middle Eocene to middle Miocene epochs. The Sixmile Creek Formation overlies the ancestral Bitterroot River deposits and is composed of locally derived, poorly sorted erosional debris of the adjacent mountains.

Quaternary glacial till underlies many of the high benches along the Bitterroot Mountains, especially in the southern part of the study area west of Darby. Quaternary alluvial-fan deposits are present along much of the western side of the valley and along the larger tributary streams on the eastern side of the valley. Quaternary alluvium and terrace deposits occur along the present flood plain of the Bitterroot River. The configuration of the water-level surface in the three focus areas was determined from water levels measured from August through December 1995.

Most wells in the Bitterroot Valley are completed in unconfined to semiconfined aquifers contained in basin-fill deposits of Quaternary and Tertiary age.

These deposits can best be described as a sequence of complexly stratified lenses of cobbles, gravel, and sand with varying amounts of intercalcated silt and clay.

Data for 9,424 wells were combined with the geologic map information to produce statistics characterizing the depth to static-water level, yield, and specific capacity of wells completed in various geologic units and in various areas of the valley. Wells completed in Quaternary alluvium and terrace deposits had the shallowest static-water levels and the largest values for yield and specific-capacity. Wells completed in Quaternary alluvial-fan deposits had similar staticwater levels but smaller values for yield and specific capacity. Wells completed in Tertiary alluvial-fan deposits had the deepest static-water levels and smallest yield and specific-capacity values of all basin-fill units analyzed. Hydraulic characteristics of the ancestral Bitterroot River deposits are between those of Quaternary deposits and Tertiary alluvial-fan deposits.

Regionally, the direction of ground-water flow in the Bitterroot Valley is from the mountain front along the basin margins toward the center of the basin and diagonally downvalley. The configuration of the water-level surface generally reflects topography, with steep hydraulic gradients in the recharge areas along the mountain front and more gradual gradients in discharge areas along the flood plain of the Bitterroot River. The configuration of the water-level surface in the three focus areas was determined from water levels measured from August through December 1995.

\section{Basin-fill aquifers in the Bitterroot Valley are} recharged by infiltration of streamflow and irrigation water, subsurface inflow from surrounding bedrock, and direct infiltration of precipitation and snowmelt. The western side of the valley receives about twice as much precipitation as the eastern side of the valley, which is probably the most significant factor affecting the quantity of recharge in those areas. Sediments along the east side of the valley are also recharged by the diversion of irrigation water from surface-water sources outside their natural drainage area. 
The largest component of discharge from basinfill aquifers is most likely seepage to streams and springs which occurs primarily in lower altitude, downgradient parts of bench areas and along the flood plain of the Bitterroot River. Evapotranspiration is probably the second largest component of discharge during the growing season. Withdrawals by wells, primarily domestic, also discharge basin-fill aquifers, although much of the water is returned to the aquifers through septic systems.

The median specific-conductance value for water from the 240 wells measured in the study area was $246 \mu \mathrm{S} / \mathrm{cm}$. The largest specific-conductance value measured was $864 \mu \mathrm{S} / \mathrm{cm} ; 54$ wells had specificconductance values less than $100 \mu \mathrm{S} / \mathrm{cm}$. The median specific-conductance value obtained from water samples from 141 wells on the east-side sediments of the valley was $347 \mu \mathrm{S} / \mathrm{cm}$, which was about 4 times as large as the median specific-conductance value of 90 $\mu \mathrm{S} / \mathrm{cm}$ obtained from the 85 wells measured on the west-side sediments side of the valley. The specific conductance of ground water is more dependent on which side of the valley the well is located than on the geologic unit in which the well is completed.

The median nitrate concentration for the 239 wells sampled in the study area was $0.63 \mathrm{mg} / \mathrm{L}$. Water from 20 wells sampled had nitrate concentrations exceeding $3 \mathrm{mg} / \mathrm{L}$. The largest nitrate concentration was $5.9 \mathrm{mg} / \mathrm{L} ; 57$ samples had nitrate concentrations below the minimum reporting level. The median nitrate concentration for samples collected from the 143 wells in the east-side sediments of the valley was $1.05 \mathrm{mg} / \mathrm{L}$--or about 6 times larger than the median of $0.17 \mathrm{mg} / \mathrm{L}$ for samples from the 83 wells completed in west-side sediments. The concentration of nitrate in ground water is more dependent on which side of the valley the well is located than on the geologic unit in which the well is completed. Data for 16 wells sampled approximately bimonthly from November 1996 through October 1997 indicate a significant seasonal variability in nitrate concentration in those wells.

On the basis of water samples collected from 43 wells, ground water in the three focus areas is primarily a calcium bicarbonate type. However, one sample in the Hamilton West area and two samples in the Hamilton Heights area are a sodium bicarbonate type. All constituent concentrations were less than MCL's except for one occurrence of cadmium equal to the
MCL of $5 \mu \mathrm{g} / \mathrm{L}$. One sample had a fluoride concentration larger than the SMCL of $2 \mu \mathrm{g} / \mathrm{L}$, six samples had iron concentrations larger than the SMCL of $300 \mu \mathrm{g} / \mathrm{L}$, and five samples had manganese concentrations larger than the SMCL of $50 \mu \mathrm{g} / \mathrm{L}$. Radon concentrations for samples from 43 wells range from 150 to $3,700 \mathrm{pCi} / \mathrm{L}$ and have a median of $810 \mathrm{pCi} / \mathrm{L}$.

Rapid and continued population growth and the resulting widespread residential development probably represent the greatest potential for change to water quality in the study area. Although the relatively small nitrate concentrations in the 239 wells sampled for this study indicate that the total nitrate load to the sampled aquifers has not resulted in nitrate concentrations that exceed recommended standards to date, significant differences exist between different parts of the study area which are pertinent to the sensitivity of the aquifers in those areas to contamination. The sensitivity of the focus-area aquifers to nitrate loading is most strongly related to the total ground-water recharge to each area--the greater the recharge, the less sensitive the aquifer is to nitrate loading. The quantity of recharge is directly related to the average annual precipitation and inversely related to the occurrence of low-permeability surface deposits, such as Tertiary alluvial-fan deposits in the area.

\section{SELECTED REFERENCES}

Barkman, P.E., 1984, A reconnaissance investigation of active tectonism in the Bitterroot Valley, western Montana: Missoula, University of Montana, M.S. thesis, $84 \mathrm{p}$.

Boettcher, A.J., and Gosling, A.W., 1977, Water resources of the Clark Fork basin upstream from St. Regis, Montana: Butte, Montana Bureau of Mines and Geology Bulletin 104, 28 p.

Briar, D.W., Lawlor, S.M., Stone, M.A.J., Parliman, D.J., Schaefer, J.L., and Kendy, Eloise, 1996, Ground-water levels in the intermontane basins of the Northern Rocky Mountains, Montana and Idaho: U.S. Geological Survey Hydrologic Investigations Atlas HA-738-B, 1 sheet, scale 1:750,000.

Cartier, K.D.W., 1984, Sediment, channel morphology, and streamflow characteristics of the Bitterroot River drainage basin, southwestern Montana: Missoula, University of Montana, M.S. thesis, 191 p. 
Clark, D.W., and Dutton, D.M., 1996, Ground-water quality in the intermontane basins of the Northern Rocky Mountains, Montana and Idaho: U.S. Geological Survey Hydrologic Investigations Atlas HA-738-C, 1 sheet, scale 1:750,000.

Cothern, C.R., 1987, Estimating the health risks of radon in drinking water: American Water Works Association Journal, v. 79, no. 4, p. 153-158.

Crosby, G.W., 1976, Geophysical study of the water bearing strata in the Bitterroot Valley, Montana: Bozeman, Mont., Montana University Joint Water Resources Research Center Report 80, 68 p.

Dutton, D.M., Lawlor, S.M., Briar, D.W., and Tresch, R.E., 1995, Hydrogeologic data for the Northern Rocky Mountains intermontane basins, Montana: U.S. Geological Survey Open-File Report 95-143, 94 p.

Fabrick, D.P., 1941, Area analysis--Bitterroot-Missoula area, Montana--preliminary statement: National Resources Planning Board Report, 104 p.

Fenneman, N.M., 1931, Physiography of western United States: New York, McGraw-Hill, 534 p.

Finstick, S.A., 1986, Hydrogeology of the Victor and Bing quadrangles, Bitterroot Valley, Montana: Missoula, University of Montana, M.S. thesis, $150 \mathrm{p}$.

Freeze, R.A., and Cherry, J.A., 1979, Groundwater: Englewood Cliffs, N.J., Prentice-Hall, 604 p.

Hodges, K.V., and Applegate, J.D., 1993, Age of Tertiary extension in the Bitterroot metamorphic core complex, Montana and Idaho: Geology, v. 21, p. 161-164.

Hoffman, J.D., 1980, Water use, groundwater conditions, and slope failure on benchlands in western Montana-The Darby slide example: Bozeman, Mont., Montana University Joint Water Resources Research Center Report 109, 48 p.

Hyndman, D.W., Talbot, J.L., and Chase, R.B., 1975, Boulder batholith--a result of emplacement of a block detached from the Idaho batholith infrastructure: Geology, v. 3, p. 401-404.

Kendy, Eloise, and Tresch, Ruth E., 1996, Geographic, geologic, and hydrologic summaries of intermontane basins of the Northern Rocky Mountains, Montana: U.S. Geological Survey Water-Resources Investigations Report 96-4025, 233 p.

Knapton, J.R., 1985, Field guidelines for collection, treatment, and analysis of water samples, Montana District: U.S. Geological Survey Open-File Report $85-409,86$ p.

Lankston, R.W., 1975, A geophysical investigation in the Bitterroot Valley, western Montana: Missoula, University of Montana, Ph.D. dissertation, $112 \mathrm{p}$.

Leonard, R.B., and Wood, W.A., 1980, Geothermal gradients in the Missoula and Bitterroot Valleys, west-central Montana: U.S. Geological Survey Water-Resources Investigations Report 80-89, 15 p.
Lonn, J.D., and Sears, J.W., 1998, Geologic map of the Bitterroot Valley, Montana: Butte, Montana Bureau of Mines and Geology Open-File Report 362, 2 sheets, scale 1:48,000.

Manghnani, M.H., and Hower, John, 1962, Structural significance of a gravity profile in the Bitterroot valley, Ravalli County, Montana: Geological Society of America Special Paper 68, p. 93.

McCulloch, Robin, 1993, Montana mining directory 1992: Butte, Montana Bureau of Mines and Geology Bulletin $131,76 \mathrm{p}$.

McMurtrey, R.G., Konizeski, R.L., Johnson, M.V., and Bartells, J.H., 1972, Geology and water resources of the Bitterroot Valley, southwestern Montana, with a section on Chemical quality of water, by H.A. Swenson: U.S. Geological Survey Water-Supply Paper 1889, 80 p.

Montana Department of Environmental Quality, 1995, Montana numeric water quality standards: Montana Department of Environmental Quality Circular WQB7, December, $39 \mathrm{p}$.

[Montana] State Engineer's Office, 1958a, Water resources survey, Ravalli County, Montana--Part 1, History of land and water use on irrigated areas: Helena, Mont., State Engineer's Office, $81 \mathrm{p}$.

[Montana] State Engineer's Office, 1958b, Water resources survey, Ravalli County, Montana--Part 2, Maps showing irrigated areas: Helena, Mont., State Engineer's Office, 31 p.

Mueller, D.K., Hamilton, P.A., Helsel, D.R., Hitt, K.J., and Ruddy, B.C., 1995, Nutrients in ground water and surface water of the United States--An analysis of data through 1992: U.S. Geological Survey WaterResources Investigations Report 95-4031, $74 \mathrm{p}$.

National Academy of Sciences and National Academy of Engineering, 1973 [1974], Water quality criteria, 1972: U.S. Environmental Protection Agency, EPA-R3-73033, $594 \mathrm{p}$.

National Oceanic and Atmospheric Administration, 1992, Monthly normals of temperature, precipitation, and heating and cooling degree days, 1961-90, Montana: Asheville, N.C., Climatography of the United States, no. 81, unpaged.

Noble, R.A., Bergantino, R.N., Patton, T.W., Sholes, B.C., Daniel, Faith, and Schofield, Judeykay, 1982, Occurrence and characteristics of ground water of Montana--Volume 2, The Rocky Mountain Region: Montana Bureau of Mines and Geology Open-File Report 99, 132 p.

Nolan, K.M., 1973, Flood hazard mapping in the Bitterroot Valley, Montana: Missoula, University of Montana, M.S. thesis, $56 \mathrm{p}$. 
Norbeck, P.M., 1980, Preliminary evaluation of deep aquifers in the Bitterroot and Missoula Valleys in western Montana: Montana Bureau of Mines and Geology Open-File Report 46, variously paged.

Nunnallee, David, and Botz, M.K., 1976, Water quality inventory and management plan, lower Clark Fork River basin, Montana: Montana Department of Health and Environmental Sciences, $129 \mathrm{p}$.

Piper, A.M., 1944, A graphic procedure in the geochemical interpretation of water analyses: American Geophysical Union Transactions, v. 25, p. 914-923.

Rorabaugh, M.I., 1963, Estimating changes in bank storage and ground-water contributions to streamflow: International Association of Scientific Hydrology Publication 63, p. 432-441.

Rorabaugh, M.I., and Simons, W.D., 1966, Exploration of methods of relating ground water to surface water, Columbia River basin--Second phase: U.S. Geological Survey Open-File Report, 99 p.

Ross, C.P., 1952, The eastern front of the Bitterroot Range: U.S. Geological Survey Bulletin 974-E, p. 135-175.

Senger, J.A., 1975, A compilation and synthesis of existing water resource information on the Bitterroot drainage, Montana: Missoula, University of Montana, M.S. thesis, $191 \mathrm{p}$.

Sonderegger, J.L., and Bergantino, R.N., 1981, Geothermal resources map of Montana: Butte, Montana Bureau of Mines and Geology Hydrogeologic Map 4, scale $1: 1,000,000$.

Tuck, L.K., Briar, D.W., and Clark, D.W., 1996, Geologic history and hydrogeologic units of intermontane basins in the Northern Rocky Mountains, Montana and Idaho: U.S. Geological Survey Hydrologic Investigations Atlas HA-738-A, 2 sheets, scale 1:750,000.

U.S. Bureau of the Census, issued annually, Intercensal estimates of population: Washington, D.C.
U.S. Bureau of the Census, issued decennially, Decennial census of population: Washington, D.C.

U.S. Environmental Protection Agency, 1996, Drinking water regulations and health advisories: U.S. Environmental Protection Agency EPA 822-B-96-002, October, $11 \mathrm{p}$.

U.S. Environmental Protection Agency, 1997, Withdrawal of the proposed national primary drinking water regulation for radon-222: accessed November 12, 1998, at URL http://www.epa.gov/ogwd/regs/ fr_radon.html/

U.S. Environmental Protection Agency, U.S. Department of Health and Human Services, and U.S. Public Health Service, 1992, A citizen's guide to radon (2d ed.)--The guide to protecting yourself and your family from radon: Washington, D.C., U.S. Government Printing Office, $15 \mathrm{p}$.

U.S. Geological Survey, issued annually, Water resources data, Montana: Helena, Mont., U.S. Geological Survey Water-Data Report.

U.S. Soil Conservation Service, 1947, Reconnaissance conservation report on water control, use and disposal, Bitterroot River drainage basin, Ravalli County, Montana: Lincoln, Neb., U.S. Department of Agriculture, Soil Conservation Service, Region 5, $53 \mathrm{p}$.

Uthman, William, 1988, Hydrogeology of the Hamilton North and Corvallis quadrangles, Bitterroot Valley, southwestern Montana: Missoula, University of Montana, M.S. thesis, 232 p.

Weber, W.M., 1972, Correlation of Pleistocene glaciation in the Bitterroot Range, Montana, with fluctuations of glacial Lake Missoula: Montana Bureau of Mines and Geology Memoir 42, $42 \mathrm{p}$.

Western Regional Climate Center, Desert Research Institute, 1999, Hamilton, Montana, monthly total precipitation (inches): accessed January 21, 1999, at URL http:// www.wrcc.dri.edu/cgi-bin/cliMAIN.pl?mthami/ 


\section{SUPPLEMENTAL DATA}


Table 4. Records of selected wells

Location number--numbering system described in text.

Altitude of land surface--in feet above sea level.

Geologic unit--Qaf, Quaternary alluvial-fan deposits; Qalt; Quaternary alluvium and terrace deposits; Tabr, Tertiary ancestral Bitterroot River deposits; Taf, Tertiary alluvial-fan deposits; TYb, Tertiary through Middle Proterozoic bedrock.

Depth of well--in feet below land surface.

Casing diameter--in inches.

Type of finish--O, open end; $P$, perforated or slotted; $S$, screen.

Depth to top of open interval-in feet below land surface.

Type of $\log$ available--D, driller.

Primary use of water--C, commercial; F, fire; H, domestic; I, irrigation; P, public supply; S, stock; U, unused.

Depth to water--in feet below land surface; flowing, water level above land surface.

Yield--in gallons per minute, reported to nearest whole number.

Specific capacity--in gallons per minute per foot of drawdown in a well.

Source of yield data--D, driller; O, owner; R, Reported; S, USGS.

Abbreviations-- ${ }^{\circ} \mathrm{C}$, degrees Celsius; $\mathrm{ft}$, feet; gal/min, gallons per minute; [(gal/min)/ft], gallons per minute per foot; in., inch; $\mu \mathrm{S} / \mathrm{cm}, \mathrm{microsiemens} \mathrm{per}$ centimeter at $25^{\circ} \mathrm{C}$.

Symbols: <, less than; --, no data or not applicable. 
Table 4. Records of selected wells (Continued)

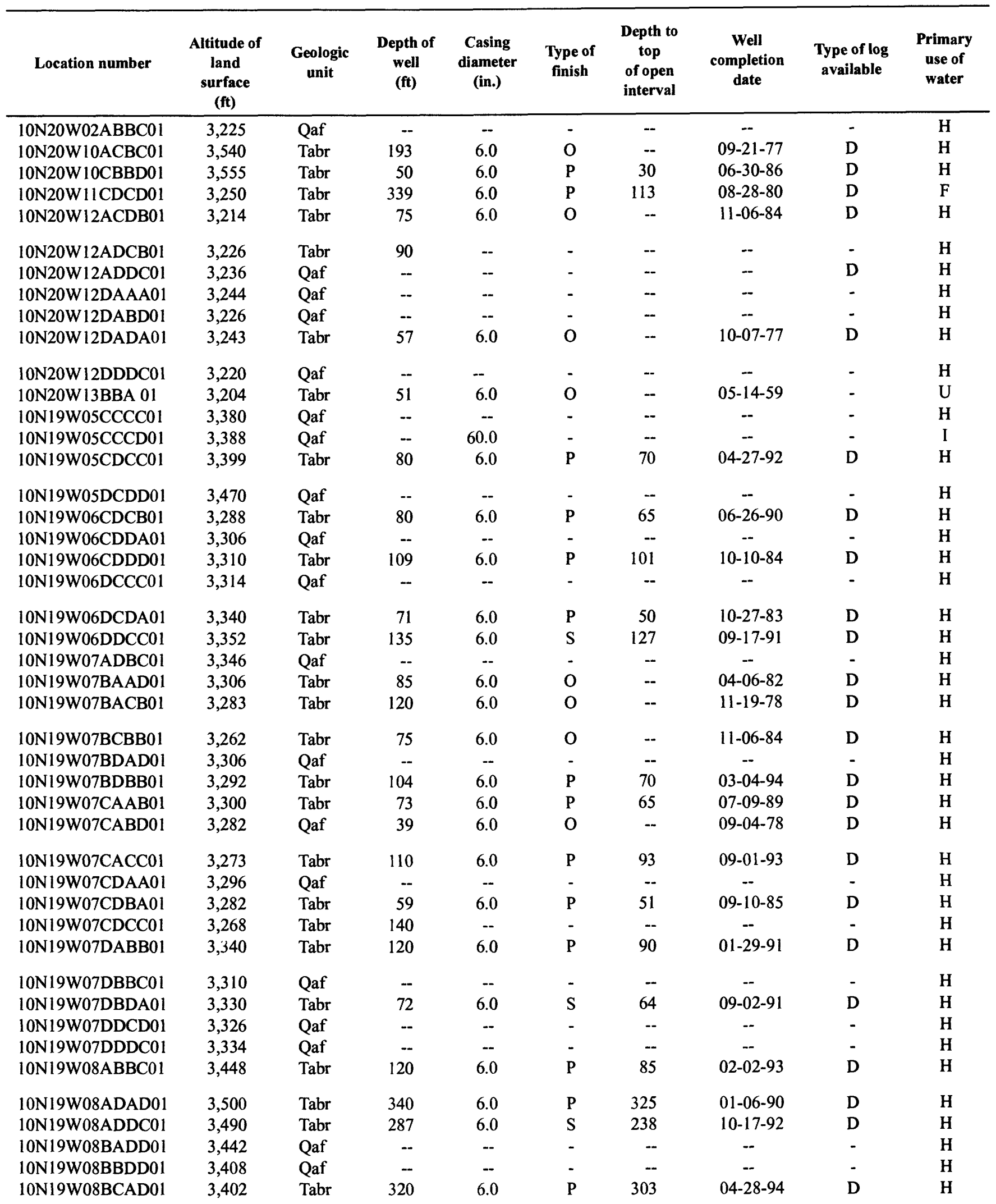




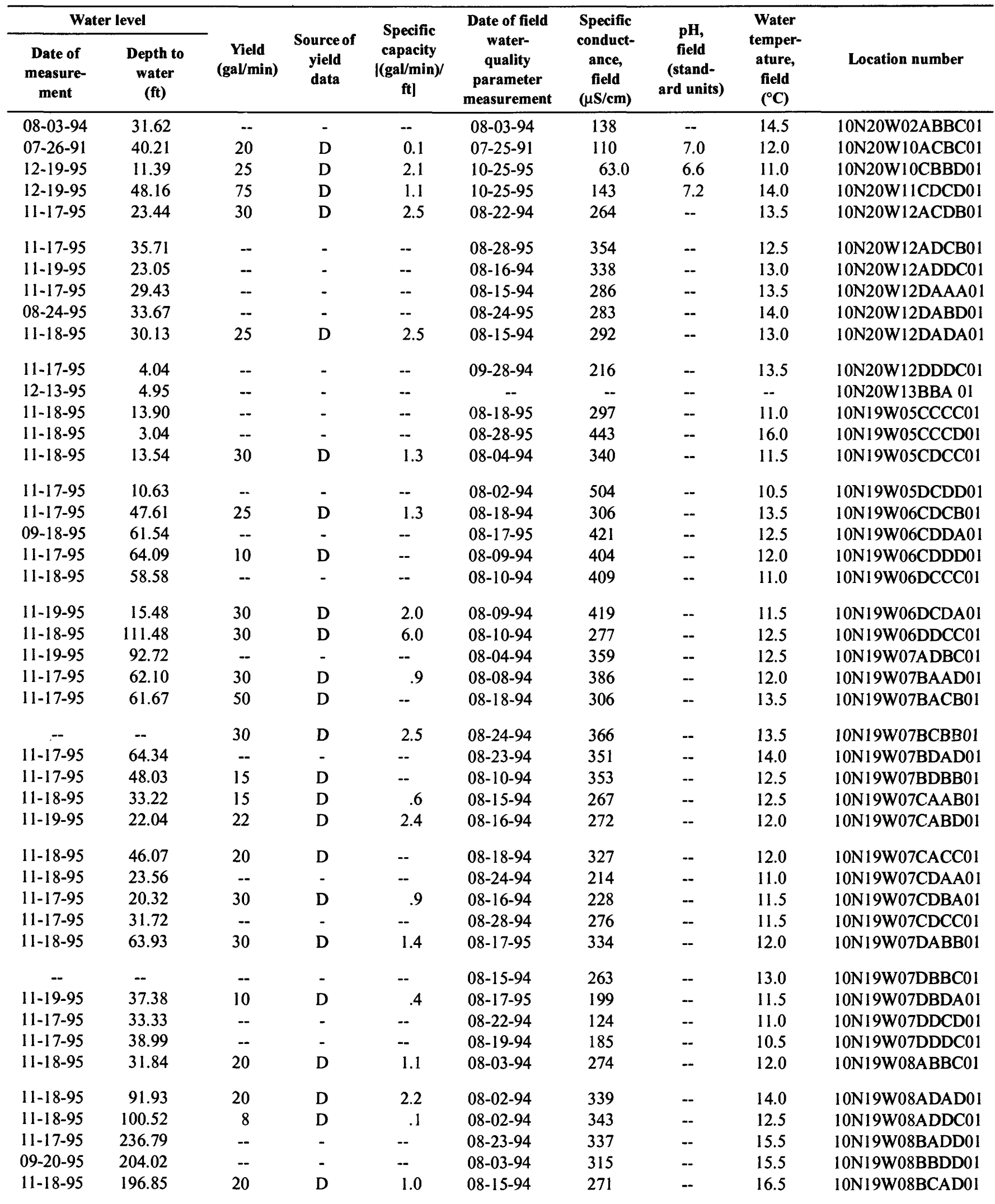


Table 4. Records of selected wells (Continued)

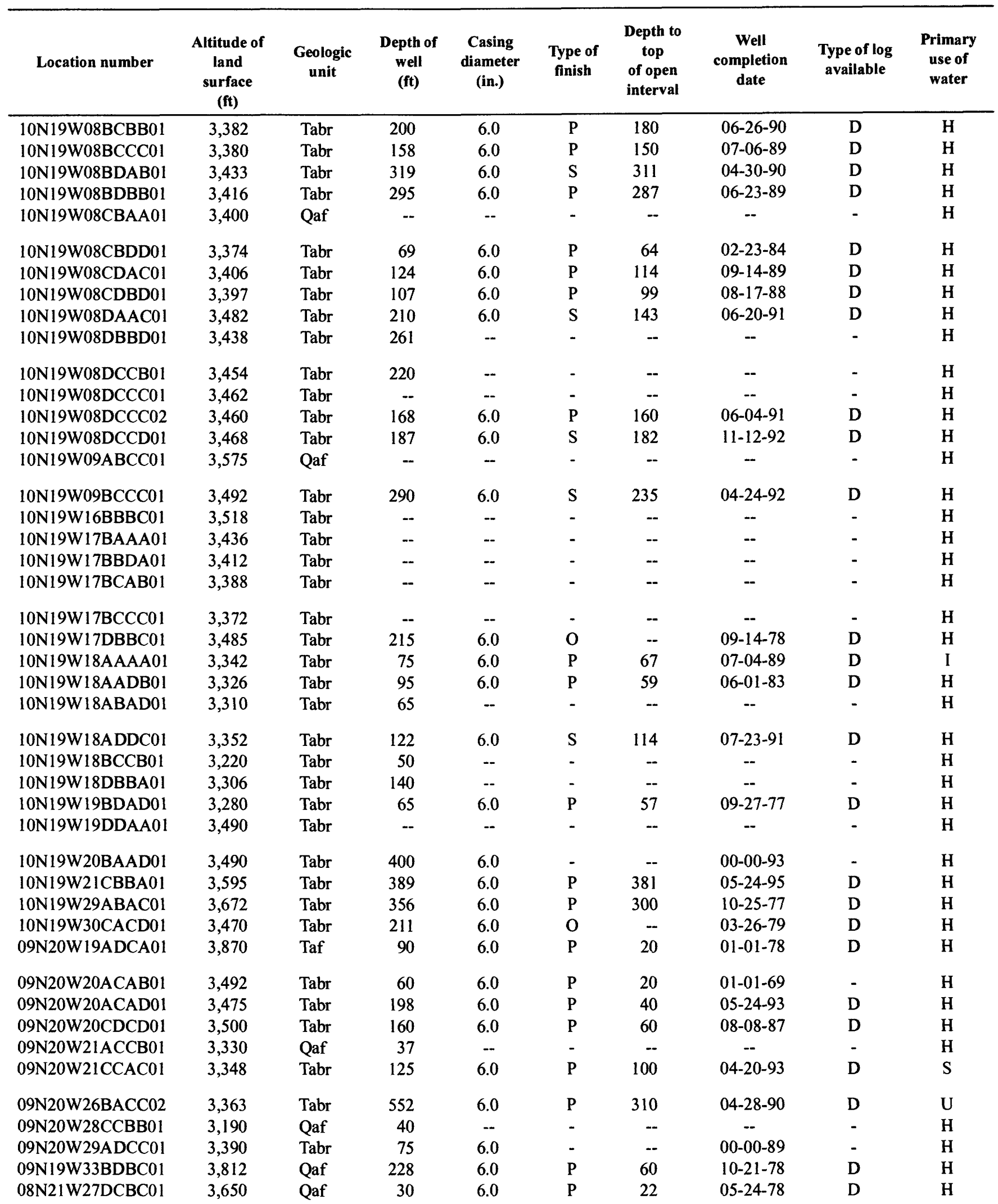




\begin{tabular}{|c|c|c|c|c|c|c|c|c|c|}
\hline \multicolumn{2}{|c|}{ Water level } & \multirow[b]{2}{*}{$\begin{array}{c}\text { Yield } \\
(\mathrm{gal} / \mathrm{min})\end{array}$} & \multirow[b]{2}{*}{$\begin{array}{c}\text { Source of } \\
\text { yield } \\
\text { data }\end{array}$} & \multirow[b]{2}{*}{$\begin{array}{c}\text { Specific } \\
\text { capacity } \\
\text { [(gal/min)/ } \\
\text { ft] }\end{array}$} & \multirow{2}{*}{$\begin{array}{c}\text { Date of field } \\
\text { water- } \\
\text { quality } \\
\text { parameter } \\
\text { measurement }\end{array}$} & \multirow{2}{*}{$\begin{array}{c}\text { Specific } \\
\text { conduct- } \\
\text { ance, } \\
\text { field } \\
(\mu \mathrm{S} / \mathrm{cm}) \\
\end{array}$} & \multirow{2}{*}{$\begin{array}{c}\text { pH, } \\
\text { field } \\
\text { (stand- } \\
\text { ard units) }\end{array}$} & \multirow{2}{*}{$\begin{array}{c}\text { Water } \\
\text { temper- } \\
\text { ature, } \\
\text { field } \\
\left({ }^{\circ} \mathrm{C}\right)\end{array}$} & \multirow[b]{2}{*}{ Location number } \\
\hline $\begin{array}{c}\text { Date of } \\
\text { measure- } \\
\text { ment }\end{array}$ & $\begin{array}{c}\text { Depth to } \\
\text { water } \\
\text { (ft) }\end{array}$ & & & & & & & & \\
\hline $11-18-95$ & 144.77 & 10 & D & .5 & $08-16-94$ & 294 & -- & 15.0 & 10N19W08BCBB01 \\
\hline $11-19-95$ & 128.79 & 30 & D & 1.5 & $08-10-94$ & 386 & -- & 12.0 & 10N19W08BCCC01 \\
\hline $11-17-95$ & 227.08 & 15 & D & .7 & 08-08-94 & 243 & -- & 15.0 & 10N19W08BDAB01 \\
\hline $08-08-94$ & 214.34 & 18 & D & .7 & $08-08-94$ & 291 & -- & 15.5 & 10N19W08BDBB01 \\
\hline $08-03-94$ & 61.22 & -- & - & -- & 08-03-94 & 306 & -- & 11.0 & 10N19W08CBAA01 \\
\hline $11-17-95$ & 51.01 & 30 & D & 1.8 & $08-16-94$ & 198 & -- & 10.0 & 10N19W08CBDD01 \\
\hline $11-17-95$ & 74.39 & 30 & D & .8 & 08-09-94 & 338 & -- & 10.5 & 10N19W08CDAC01 \\
\hline-- & -- & 30 & D & 3.0 & $08-18-95$ & 257 & -- & 10.0 & 10N19W08CDBD01 \\
\hline $11-17-95$ & 68.53 & 5 & D & -- & $08-23-94$ & 168 & -- & 13.5 & 10N19W08DAAC01 \\
\hline $11-17-95$ & 198.23 & -- & - & -- & $08-28-95$ & 195 & -- & 13.5 & 10N19W08DBBD01 \\
\hline $11-17-95$ & 115.69 & -- & - & -- & $08-28-95$ & 274 & -- & 11.0 & 10N19W08DCCB01 \\
\hline $08-19-94$ & 136.80 & -- & - & -- & $08-19-94$ & 280 & -- & 11.0 & 10N19W08DCCC01 \\
\hline $12-19-95$ & 139.97 & 20 & D & .3 & $10-26-95$ & 258 & 7.2 & 11.0 & 10N19W08DCCC02 \\
\hline $06-06-95$ & 150.85 & 50 & D & 1.4 & -- & -- & - & -- & 10N19W08DCCD01 \\
\hline- & -- & -- & - & -- & $08-02-94$ & 341 & -- & 11.0 & 10N19W09ABCC01 \\
\hline $11-17-95$ & 56.95 & 9 & D & 26.7 & $08-18-94$ & 201 & -- & 11.0 & 10N19W09BCCC01 \\
\hline $11-18-95$ & 203.84 & -- & - & -- & $08-24-94$ & 184 & -- & 13.5 & 10N19W16BBBC01 \\
\hline $11-17-95$ & 119.35 & -- & - & -- & $08-08-94$ & 237 & -- & 11.5 & 10N19W17BAAA01 \\
\hline $11-17-95$ & 90.62 & - & - & -- & $08-19-94$ & 182 & -- & 9.5 & 10N19W17BBDA01 \\
\hline $11-17-95$ & 84.35 & -- & - & -- & $08-19-94$ & 193 & -- & 10.5 & 10N19W17BCAB01 \\
\hline $11-17-95$ & 93.95 & -- & - & -- & -- & -- & -- & -- & $10 \mathrm{~N} 19 \mathrm{~W} 17 \mathrm{BCCC} 01$ \\
\hline $12-11-95$ & 179.32 & 15 & D & .4 & $12-11-95$ & 210 & 7.3 & 12.0 & 10N19W17DBBC01 \\
\hline $08-24-94$ & 45.23 & 30 & D & 1.5 & $08-24-94$ & 168 & -- & 11.5 & I0N19W18AAAA01 \\
\hline $11-17-95$ & 42.91 & 40 & D & 3.3 & $08-28-95$ & 175 & -- & 11.0 & 10N19W18AADB01 \\
\hline $11-17-95$ & 30.28 & -- & - & -- & -- & -- & -- & - & 10N19W18ABAD01 \\
\hline $11-17-95$ & 81.93 & 40 & D & 2.0 & -- & -- & -- & -- & 10N19W18ADDC01 \\
\hline $01-21-95$ & 26.95 & - & - & -- & -- & -- & -- & - & 10N19W18BCCB01 \\
\hline $11-19-95$ & 68.82 & -- & - & -- & $09-13-95$ & 186 & 6.9 & 10.0 & 10N19W18DBBA01 \\
\hline $10-25-95$ & 50.60 & 12 & D & .8 & $10-25-95$ & 214 & 7.0 & 10.5 & 10N19W19BDAD01 \\
\hline $10-25-95$ & 167.94 & -- & - & -- & $10-25-95$ & 210 & 7.3 & 14.0 & 10N19W19DDAA01 \\
\hline $10-24-95$ & 205.56 & -- & - & -- & $10-24-95$ & 191 & 7.1 & 13.5 & 10N19W20BAAD01 \\
\hline $10-24-95$ & 362.63 & 10 & D & .5 & $10-24-95$ & 243 & 7.0 & 14.5 & 10N19W21CBBA01 \\
\hline $10-24-95$ & 312.98 & 12 & D & .6 & $10-24-95$ & 274 & 7.4 & 13.5 & 10N19W29ABAC01 \\
\hline-- & - & 10 & D & 5.0 & $10-24-95$ & 236 & 7.2 & 11.0 & 10N19W30CACD01 \\
\hline $10-23-95$ & 16.38 & 3 & - & .1 & $10-23-95$ & 141 & 6.4 & 12.0 & 09N20W19ADCA01 \\
\hline $10-11-95$ & 32.95 & 2 & $\mathrm{O}$ & .1 & $10-11-95$ & 118 & 6.5 & 11.0 & 09N20W20ACAB01 \\
\hline $12-19-95$ & 27.39 & 4 & D & .3 & $06-03-96$ & 128 & 6.5 & 10.0 & 09N20W20ACAD01 \\
\hline 09-14-95 & 22.13 & 10 & D & .1 & $09-14-95$ & 230 & 8.3 & 10.0 & 09N20W20CDCD01 \\
\hline $10-11-95$ & 10.51 & -- & - & -- & $10-11-95$ & 42.9 & 6.2 & 12.5 & 09N20W21ACCB01 \\
\hline $12-14-95$ & .21 & 15 & D & -- & $12-14-95$ & 287 & 7.4 & 10.5 & 09N20W21CCAC01 \\
\hline $12-19-95$ & 79.14 & 218 & D & 4.8 & -- & -- & -- & -- & 09N20W26BACC02 \\
\hline-- & -- & -- & - & -- & $10-11-95$ & 193 & 6.6 & 10.5 & 09N20W28CCBB01 \\
\hline $10-23-95$ & 47.29 & -- & - & -- & $10-23-95$ & 256 & 6.8 & 10.5 & 09N20W29ADCC01 \\
\hline-- & -- & 8 & D & -- & $08-22-95$ & 177 & 7.4 & 18.0 & 09N19W33BDBC01 \\
\hline $12-19-95$ & 7.11 & 40 & D & 2.5 & $06-03-96$ & 70.6 & 6.6 & 8.5 & 08N2I W27DCBC01 \\
\hline
\end{tabular}


Table 4. Records of selected wells (Continued)

\begin{tabular}{|c|c|c|c|c|c|c|c|c|c|}
\hline Location number & $\begin{array}{l}\text { Altitude of } \\
\text { land } \\
\text { surface } \\
\text { (ft) }\end{array}$ & $\begin{array}{c}\text { Geologic } \\
\text { unit }\end{array}$ & $\begin{array}{l}\text { Depth of } \\
\text { well } \\
\text { (ft) }\end{array}$ & $\begin{array}{l}\text { Casing } \\
\text { diameter } \\
\text { (in.) }\end{array}$ & $\begin{array}{l}\text { Type of } \\
\text { finish }\end{array}$ & $\begin{array}{l}\text { Depth to } \\
\text { top } \\
\text { of open } \\
\text { interval }\end{array}$ & $\begin{array}{c}\text { Well } \\
\text { completion } \\
\text { date }\end{array}$ & $\begin{array}{l}\text { Type of log } \\
\text { available }\end{array}$ & $\begin{array}{c}\text { Primary } \\
\text { use of } \\
\text { water }\end{array}$ \\
\hline 08N20W01ACCB01 & 3,762 & Taf & 135 & 6.0 & $P$ & 127 & $04-15-89$ & D & $\mathrm{H}$ \\
\hline 08N20W01DAAD01 & 3,828 & Taf & 70 & 6.0 & 0 & -- & $08-10-77$ & D & $\mathrm{U}$ \\
\hline 08N20W01DABD01 & 3,822 & Taf & 132 & 6.0 & $\mathrm{O}$ & - & $01-27-78$ & D & $\mathbf{H}$ \\
\hline 08N20W02CBDB01 & 3,535 & Taf & 222 & 6.0 & - & -- & $00-00-80$ & - & $\mathbf{H}$ \\
\hline 08N20W11BDAA01 & 3,585 & Tabr & 279 & 6.0 & $\mathbf{P}$ & 271 & $11-25-77$ & D & $\mathbf{H}$ \\
\hline 08N20W11CCAD01 & 3,610 & Tabr & 308 & 6.0 & $\mathrm{O}$ & - & $08-06-85$ & D & $\mathbf{H}$ \\
\hline 08N20W12BAAA01 & 3,810 & Taf & 108 & 6.0 & $\mathbf{P}$ & 100 & 01-01-89 & D & $\mathbf{H}$ \\
\hline 08N20W13BBDB01 & 3,802 & Tabr & 525 & 6.0 & $\mathrm{O}$ & -- & $01-01-69$ & - & $\mathbf{H}$ \\
\hline 08N20W14ABDB01 & 3,690 & Tabr & 367 & 6.0 & $\mathbf{P}$ & 362 & $01-01-88$ & - & $\mathbf{H}$ \\
\hline 08N20W19BAAD03 & 3,393 & Tabr & 52 & 6.0 & $\mathrm{O}$ & - & $06-20-57$ & D & $\mathrm{U}$ \\
\hline 08N20W23CDDD01 & 3,545 & Taf & 232 & 6.0 & $\mathrm{O}$ & -- & $07-20-84$ & D & $\mathrm{H}$ \\
\hline 08N20W26BAAC01 & 3,510 & Tabr & 440 & 6.0 & $\mathbf{P}$ & 145 & $09-30-92$ & D & $\mathrm{H}$ \\
\hline 08N20W30CDAB01 & 3,407 & Qaf & 39 & 6.0 & $\mathbf{P}$ & 34 & 08-09-89 & D & $\mathbf{P}$ \\
\hline 08N19W04BDAA01 & 3,950 & Tabr & 56 & 6.0 & $\mathbf{P}$ & 51 & $02-28-85$ & D & $\mathrm{H}$ \\
\hline 08N19W07CBBD01 & 3,893 & Taf & 117 & 48 & $\mathrm{O}$ & - & $00-00-56$ & - & $\mathrm{H}$ \\
\hline 08N19W10BBCA01 & 4,079 & Tabr & 70 & 6.0 & $\mathrm{O}$ & -- & $02-15-45$ & - & $\mathbf{H}$ \\
\hline 08N19W11CDBB01 & 4,260 & Tabr & 50 & 6.0 & $\mathbf{P}$ & 42 & $12-21-79$ & D & $\mathbf{H}$ \\
\hline 07N21 W13BBAD01 & 3,590 & Tabr & 100 & 6.0 & $\mathrm{O}$ & - & $06-13-79$ & D & $\mathbf{H}$ \\
\hline 07N21 W25CABC01 & 3,489 & Tabr & 48 & 6.0 & $\mathbf{P}$ & 35 & $10-17-87$ & D & $\mathbf{H}$ \\
\hline 07N21 W36DDDC01 & 3,487 & Qalt & 31 & 6.0 & $\mathbf{P}$ & 23 & $10-20-76$ & D & $\mathbf{H}$ \\
\hline 07N20W32DDDA02 & 3,473 & Qalt & 40 & 8.0 & $\mathrm{O}$ & - & $00-00-62$ & - & $\mathrm{F}$ \\
\hline 07N20W34CCCD01 & 3,546 & Tabr & 90 & 6.0 & $\mathrm{O}$ & -- & $06-09-80$ & D & $\mathbf{H}$ \\
\hline 07N20W34CDDB01 & 3,568 & Tabr & 94 & 6.0 & $\mathrm{O}$ & -- & 03-05-94 & D & $\mathbf{H}$ \\
\hline 07N20W36CCCA01 & 3,741 & Taf & -- & -- & - & -- & -- & - & $\mathbf{H}$ \\
\hline 06N21 W01ACDA01 & 3,520 & Qaf & 35 & 8.0 & - & -- & $00-00-30$ & D & $\mathbf{H}$ \\
\hline 06N21 W01CADD01 & 3,547 & Tabr & 63 & 6.0 & $\mathrm{O}$ & -- & $10-25-78$ & D & $\mathbf{H}$ \\
\hline 06N21 W01 CBAB01 & 3,590 & Tabr & 80 & 6.0 & - & -- & $00-00-92$ & - & $\mathbf{H}$ \\
\hline 06N21 W01 CBAB02 & 3,590 & Qaf & - & -- & - & -- & -- & - & $\mathrm{U}$ \\
\hline 06N21 W02ABBD01 & 3,750 & Taf & 89 & 4.0 & - & -- & -- & - & $\mathbf{H}$ \\
\hline 06N21 W02CADD01 & 3,692 & Tabr & 137 & 5.5 & S & 108 & $10-24-77$ & D & $\mathbf{H}$ \\
\hline 06N21 W03ACBA01 & 3,839 & Tabr & 42 & 6.0 & $\mathrm{O}$ & -- & $10-29-73$ & D & $\mathbf{H}$ \\
\hline 06N21 W03CAAC01 & 3,852 & Tabr & 42 & 6.0 & $\mathbf{P}$ & 37 & $11-16-71$ & D & $\mathbf{H}$ \\
\hline 06N21 W03CCDD01 & 3,965 & Taf & 40 & 6.0 & $S$ & 20 & 04-01-91 & D & $\mathrm{H}$ \\
\hline 06N21 W03CDAC01 & 3,825 & Tabr & 320 & 6.0 & $\mathbf{P}$ & -- & $03-07-78$ & D & $\mathrm{U}$ \\
\hline 06N21 W03DDAA01 & 3,760 & Qaf & 34 & 6.0 & $\mathbf{P}$ & 26 & $04-10-78$ & D & H \\
\hline 06N21 W09DADA01 & 4,045 & Tabr & 412 & 6.0 & $\mathbf{P}$ & 352 & $09-04-81$ & D & $\mathbf{H}$ \\
\hline 06N21 W10BDDD01 & 3,885 & Taf & -- & -- & - & - & -- & - & $\mathbf{H}$ \\
\hline 06N21 W11ABAA01 & 3,632 & Tabr & 136 & 6.0 & $\mathbf{P}$ & 128 & $02-08-79$ & D & $\mathbf{H}$ \\
\hline 06N21 W11CAAA01 & 3,632 & Tabr & 60 & 6.0 & - & - & - & - & $\mathbf{H}$ \\
\hline 06N21W11CBCA01 & 3,695 & Qaf & 36 & 6.0 & $\mathrm{O}$ & -- & $07-26-78$ & D & $\mathbf{H}$ \\
\hline 06N21W11CBDC01 & 3,705 & Tabr & 180 & 6.0 & $\mathrm{O}$ & -- & $04-22-94$ & D & $\mathbf{H}$ \\
\hline 06N21 W11 CDCB01 & 3,630 & Tabr & 75 & 6.0 & $\mathbf{P}$ & 67 & $09-22-90$ & D & $\mathbf{H}$ \\
\hline 06N21 W11DCCA01 & 3,630 & Qaf & -- & -- & - & - & -- & - & $\mathbf{H}$ \\
\hline $06 \mathrm{~N} 21 \mathrm{~W} 12 \mathrm{ABAB} 01$ & 3,502 & Tabr & 42 & 4.0 & - & -- & $06-53$ & - & $\mathbf{H}$ \\
\hline 06N21 W12BDDD01 & 3,545 & Tabr & 270 & 6.0 & $\mathbf{P}$ & 45 & $06-22-76$ & D & $\mathrm{H}$ \\
\hline
\end{tabular}




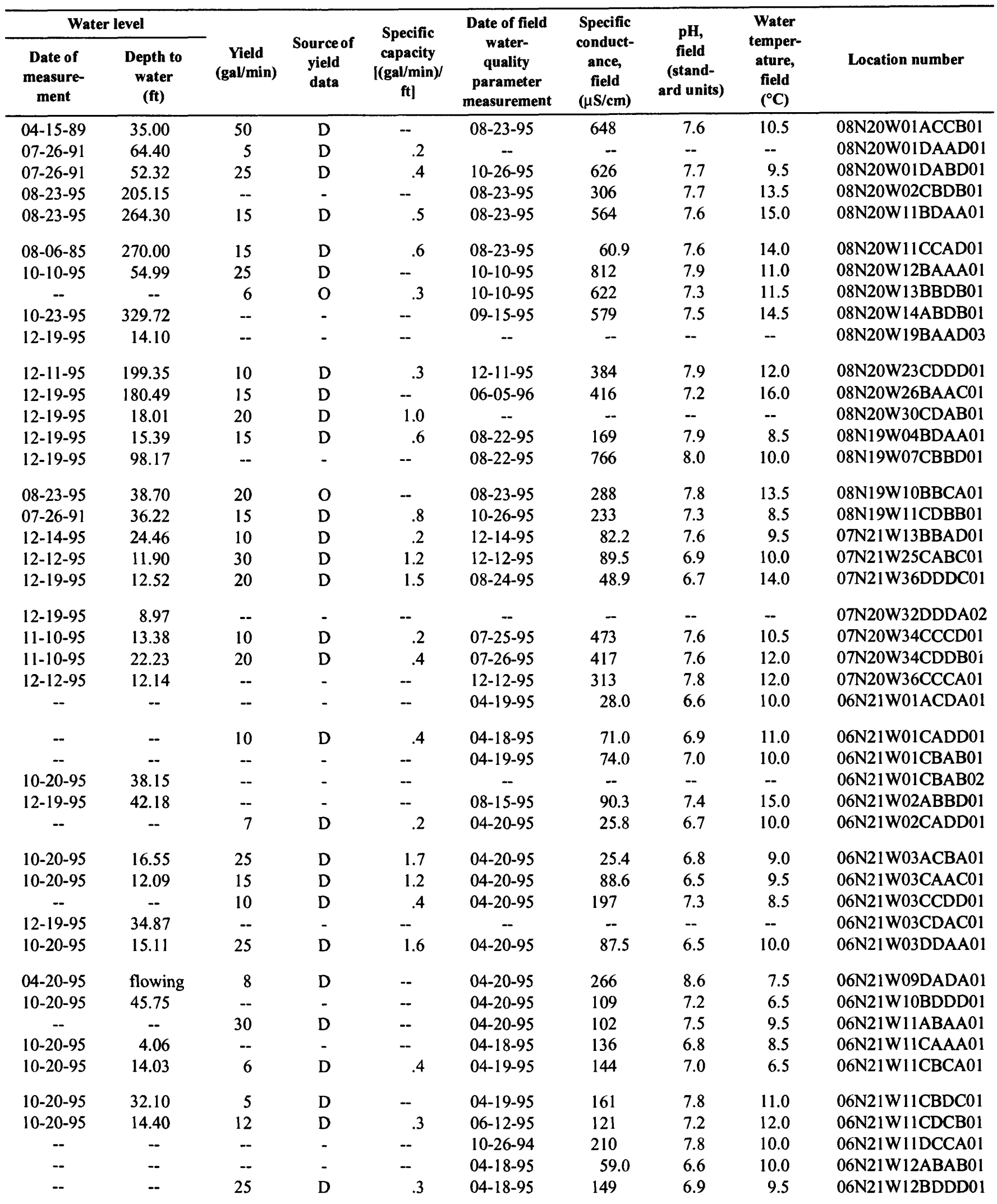


Table 4. Records of selected wells (Continued)

\begin{tabular}{|c|c|c|c|c|c|c|c|c|c|}
\hline Location number & $\begin{array}{l}\text { Altitude of } \\
\text { land } \\
\text { surface } \\
\text { (ft) }\end{array}$ & $\begin{array}{c}\text { Geologic } \\
\text { unit }\end{array}$ & $\begin{array}{c}\text { Depth of } \\
\text { well } \\
\text { (ft) }\end{array}$ & $\begin{array}{l}\text { Casing } \\
\text { diameter } \\
\text { (in.) }\end{array}$ & $\begin{array}{l}\text { Type of } \\
\text { finish }\end{array}$ & $\begin{array}{l}\text { Depth to } \\
\text { top } \\
\text { of open } \\
\text { interval }\end{array}$ & $\begin{array}{c}\text { Well } \\
\text { completion } \\
\text { date }\end{array}$ & $\begin{array}{l}\text { Type of log } \\
\text { available }\end{array}$ & $\begin{array}{c}\text { Primary } \\
\text { use of } \\
\text { water }\end{array}$ \\
\hline 06N21W13BADC01 & 3,582 & Tabr & 43 & 6.0 & - & -- & $00-00-86$ & - & $\mathbf{H}$ \\
\hline 06N21W13BBAB01 & 3,662 & Tabr & 138 & 6.0 & $\mathbf{P}$ & 120 & $05-19-92$ & D & $\mathbf{H}$ \\
\hline 06N21W13CCCD01 & 3,622 & Qaf & -- & -- & - & -- & -- & - & $\mathbf{H}$ \\
\hline 06N21 W13DBBD01 & 3,542 & Qaf & -- & - & - & -- & -- & - & $\mathbf{H}$ \\
\hline 06N21 W14BCBD01 & 3,818 & Tabr & 99 & 6.0 & $\mathbf{P}$ & 91 & $01-11-79$ & D & $\mathbf{H}$ \\
\hline 06N21W14BDAC01 & 3,718 & Tabr & 48 & 6.0 & $\mathbf{P}$ & 40 & $06-25-92$ & D & $\mathbf{H}$ \\
\hline 06N21 W14DAAD01 & 3,630 & Tabr & 54 & 6.0 & $\mathbf{P}$ & 49 & 04-28-69 & D & $\mathbf{H}$ \\
\hline $06 \mathrm{~N} 21 \mathrm{~W} 15 \mathrm{ABBB} 01$ & 3,885 & Taf & 132 & 6.0 & - & -- & $09-19-62$ & - & $\mathbf{H}$ \\
\hline 06N21 W15ADBC01 & 3,850 & Tabr & 300 & 6.0 & $\mathbf{P}$ & 100 & $07-12-80$ & D & $\mathbf{H}$ \\
\hline 06N21 W15CDDD01 & 3,918 & Tabr & 120 & 6.0 & $\mathbf{P}$ & 70 & $10-01-79$ & D & $\mathbf{H}$ \\
\hline 06N21 W21ADDB01 & 4,190 & Tabr & 162 & 6.0 & $\mathbf{P}$ & 154 & $12-13-90$ & D & $\mathbf{H}$ \\
\hline 06N21W22AADC01 & 3,820 & Tabr & 41 & 6.0 & - & - & $04-12-55$ & - & $\mathbf{H}$ \\
\hline 06N21 W22BCCA01 & 4,100 & Tabr & 132 & 6.0 & $\mathbf{P}$ & 124 & $05-10-89$ & D & $\mathbf{H}$ \\
\hline 06N21W22CACA01 & 3,985 & Tabr & 81 & 6.0 & $\mathbf{P}$ & 73 & $02-07-83$ & D & $\mathbf{H}$ \\
\hline 06N21 W23ADAA01 & 3,638 & Qaf & 40 & -- & - & -- & $00-00-38$ & - & $\mathbf{H}$ \\
\hline 06N21 W23BABB01 & 3,750 & Qaf & - & -- & - & -- & -- & - & $\mathbf{H}$ \\
\hline 06N21 W23BDDD01 & 3,705 & Qaf & 29 & 6.0 & $\mathbf{P}$ & 24 & $08-03-73$ & D & $\mathbf{H}$ \\
\hline 06N21 W23CABC01 & 3,815 & Tabr & 135 & 6.0 & $\mathrm{O}$ & -- & $06-10-85$ & D & $\mathbf{H}$ \\
\hline 06N21W23CBCB01 & 3,862 & Tabr & 160 & 6.0 & $\mathbf{P}$ & 140 & $08-16-78$ & D & $\mathbf{H}$ \\
\hline 06N21W23CDCB01 & 3,775 & Tabr & 86 & 6.0 & $\mathrm{O}$ & - & $01-16-80$ & D & $\mathbf{H}$ \\
\hline 06N21 W23DADA01 & 3,618 & Qaf & 33 & 6.0 & - & -- & -- & - & $\mathbf{H}$ \\
\hline 06N21W23DADD01 & 3,610 & Tabr & 42 & 6.0 & - & -- & - & - & $\mathbf{H}$ \\
\hline 06N21W23DBDA01 & 3,665 & Qaf & 30 & -- & - & -- & -- & - & $\mathbf{H}$ \\
\hline 06N21 W23DDAA01 & 3,610 & Qaf & 38 & 6.0 & $\mathrm{P}$ & 30 & $07-01-91$ & D & $\mathbf{H}$ \\
\hline 06N21 W23DDAD01 & 3,598 & Qaf & 35 & 6.0 & - & -- & $07--47$ & - & $\mathbf{H}$ \\
\hline 06N21 W23DDBB01 & 3,641 & Qaf & 38 & 6.0 & $\mathbf{P}$ & 30 & $04-14-89$ & D & $\mathbf{H}$ \\
\hline 06N21 W23DDCB01 & 3,615 & Qaf & 40 & 6.0 & $\mathrm{O}$ & -- & $08-14-68$ & D & $\mathbf{H}$ \\
\hline 06N21 W23DDDA01 & 3,595 & Qaf & 15 & 12.0 & - & -- & $06-54$ & - & $\mathbf{H}$ \\
\hline 06N21 W24BAAC01 & 3,562 & Qaf & 40 & 6.0 & $\mathrm{O}$ & -- & $11-27-78$ & $\mathrm{D}$ & $\mathbf{H}$ \\
\hline 06N21 W24BDCC01 & 3,590 & Tabr & 112 & 4.0 & - & - & $00-00-43$ & - & $\mathbf{H}$ \\
\hline 06N21 W24CCAC01 & 3,575 & Tabr & 50 & 6.0 & 0 & -- & $04-27-77$ & D & $\mathbf{H}$ \\
\hline 06N21 W24CCBB01 & 3,599 & Tabr & 16 & 6.0 & - & -- & -- & - & $\mathrm{U}$ \\
\hline $06 \mathrm{~N} 21 \mathrm{~W} 24 \mathrm{CCBB} 02$ & 3,601 & Qaf & 33 & 6.0 & $\mathbf{P}$ & 26 & $08-04-73$ & D & $\mathrm{U}$ \\
\hline 06N21 W24CCCB01 & 3,588 & Qaf & 43 & 6.0 & $\mathrm{O}$ & -- & -- & - & $\mathbf{H}$ \\
\hline 06N21 W25DBAA01 & 3,570 & Tabr & 66 & 12.0 & - & -- & $04-10-46$ & - & $\mathbf{P}$ \\
\hline 06N21W26AADD01 & 3,565 & Tabr & 50 & 6.0 & $\mathrm{O}$ & -- & $08-12-68$ & D & $\mathbf{H}$ \\
\hline 06N21W26ABAD01 & 3,695 & Tabr & 128 & 6.0 & $\mathrm{O}$ & -- & $09-27-67$ & D & $\mathbf{H}$ \\
\hline 06N21W26BBCA01 & 3,779 & Tabr & 60 & 6.0 & - & -- & $00-00-83$ & - & $\mathbf{H}$ \\
\hline 06N21 W26CBAB01 & 3,705 & Tabr & 60 & -- & - & -- & -- & - & $\mathrm{H}$ \\
\hline 06N21 W26DBAD01 & 3,613 & Tabr & 79 & 6.0 & $\mathbf{P}$ & 74 & $01-15-81$ & $\mathrm{D}$ & I \\
\hline 06N21W26DBDD01 & 3,601 & Tabr & 174 & 6.0 & $\mathbf{P}$ & 140 & $04-22-94$ & D & I \\
\hline 06N21 W27ADBC01 & 3,835 & Tabr & 60 & 6.0 & $\mathbf{P}$ & 52 & $09-26-77$ & D & $\mathrm{H}$ \\
\hline 06N21 W27BABA01 & 3,892 & Tabr & 278 & 6.0 & $\mathbf{P}$ & 140 & $08-16-83$ & D & $\mathrm{H}$ \\
\hline $06 \mathrm{~N} 21 \mathrm{~W} 27 \mathrm{BBAA01}$ & 4,030 & Tabr & 126 & 6.0 & $\mathrm{O}$ & -- & $06-12-75$ & D & $\mathbf{H}$ \\
\hline 06N21W34ABCD01 & 3,762 & Qaf & 39 & -- & - & - & $00-00-81$ & - & $\mathrm{H}$ \\
\hline
\end{tabular}




\begin{tabular}{|c|c|c|c|c|c|c|c|c|c|}
\hline \multicolumn{2}{|c|}{ Water level } & \multirow[b]{2}{*}{$\begin{array}{c}\text { Yield } \\
\text { (gal/min) }\end{array}$} & \multirow[b]{2}{*}{$\begin{array}{c}\text { Source of } \\
\text { yield } \\
\text { data }\end{array}$} & \multirow{2}{*}{$\begin{array}{c}\text { Specific } \\
\text { capacity } \\
{[(\mathrm{gal} / \mathrm{min}) /} \\
\mathrm{ft}]\end{array}$} & \multirow{2}{*}{$\begin{array}{c}\text { Date of field } \\
\text { water- } \\
\text { quality } \\
\text { parameter } \\
\text { measurement }\end{array}$} & \multirow{2}{*}{$\begin{array}{c}\text { Specific } \\
\text { conduct- } \\
\text { ance, } \\
\text { field } \\
(\mu \mathrm{S} / \mathrm{cm})\end{array}$} & \multirow{2}{*}{$\begin{array}{c}\text { pH, } \\
\text { field } \\
\text { (stand- } \\
\text { ard units) }\end{array}$} & \multirow{2}{*}{$\begin{array}{c}\text { Water } \\
\text { temper- } \\
\text { ature, } \\
\text { field } \\
\left({ }^{\circ} \mathrm{C}\right) \\
\end{array}$} & \multirow[b]{2}{*}{ Location number } \\
\hline $\begin{array}{c}\text { Date of } \\
\text { measure- } \\
\text { ment }\end{array}$ & $\begin{array}{c}\text { Depth to } \\
\text { water } \\
\text { (ft) }\end{array}$ & & & & & & & & \\
\hline-- & - & -- & - & - & $04-18-95$ & 143 & 7.8 & 11.5 & 06N21W13BADC01 \\
\hline $10-20-95$ & 66.68 & 25 & $\mathrm{D}$ & 3.1 & 04-18-95 & 90.0 & 7.6 & 11.0 & 06N21W13BBAB01 \\
\hline-- & -- & -- & - & - & $10-26-94$ & 89.9 & 6.2 & 11.5 & 06N21W13CCCD01 \\
\hline-- & - & -- & - & - & $05-01-95$ & 106 & 6.4 & 11.0 & 06N21W13DBBD01 \\
\hline-- & -- & 15 & D & .8 & $04-19-95$ & 57.3 & 7.0 & 10.0 & 06N21 W14BCBD01 \\
\hline $10-20-95$ & 13.39 & 22 & $\mathrm{D}$ & .8 & $10-26-94$ & 82.2 & 7.1 & 12.0 & 06N21W14BDAC01 \\
\hline $10-26-94$ & 4.14 & 20 & D & 4.0 & $10-26-94$ & 58.3 & 6.1 & 9.0 & 06N21W14DAAD01 \\
\hline $10-20-95$ & 89.85 & 50 & $\mathrm{O}$ & - & $04-19-95$ & 75.8 & 6.7 & 10.0 & 06N21W15ABBB01 \\
\hline $10-20-95$ & 135.60 & 5 & D & .1 & $06-12-95$ & 101 & 7.7 & 12.0 & $06 \mathrm{~N} 21 \mathrm{~W} 15 \mathrm{ADBC} 01$ \\
\hline $10-20-95$ & 44.87 & 9 & $\mathrm{~S}$ & 2.0 & $10-26-94$ & 50.3 & 6.4 & 9.5 & 06N21W15CDDD01 \\
\hline $10-20-95$ & 129.19 & 10 & D & .7 & $10-25-94$ & 122 & 7.2 & 11.0 & 06N21 W21ADDB01 \\
\hline-- & -- & 60 & $\mathrm{O}$ & -- & $04-20-95$ & 40.1 & 6.7 & 9.5 & 06N21 W22AADC01 \\
\hline $10-20-95$ & 91.49 & 12 & D & -- & $08-29-94$ & 124 & 7.0 & 11.0 & 06N21W22BCCA01 \\
\hline-- & -- & 4 & $\mathrm{D}$ & .2 & $08-29-94$ & 120 & 6.4 & 13.5 & 06N21W22CACA01 \\
\hline-- & - & -- & - & -- & $10-25-94$ & 47.2 & 6.2 & 11.5 & 06N21 W23ADAA01 \\
\hline-- & -- & -- & - & -- & $10-25-94$ & 28.4 & 6.1 & 11.5 & 06N21W23BABB01 \\
\hline-- & - & 20 & D & 1.0 & $08-30-94$ & 36.2 & 6.3 & 12.5 & 06N21 W23BDDD01 \\
\hline $10-20-95$ & 102.25 & 10 & D & .2 & $06-12-95$ & 79.0 & 7.1 & 10.0 & 06N21W23CABC01 \\
\hline $10-20-95$ & 94.92 & 10 & D & .2 & $09-13-94$ & 110 & 7.1 & 11.0 & 06N21W23CBCB01 \\
\hline $10-20-95$ & 48.52 & 12 & D & 1.2 & $08-30-94$ & 105 & 6.6 & 12.0 & 06N21 W23CDCB01 \\
\hline $10-20-95$ & 5.22 & -- & - & -- & 09-01-94 & 48.4 & 6.1 & 10.5 & 06N21 W23DADA01 \\
\hline $10-20-95$ & 6.78 & -- & - & -- & $08-31-94$ & 54.0 & 6.1 & 11.0 & 06N21 W23DADD01 \\
\hline-- & -- & - & - & -- & $07-10-95$ & 43.9 & 6.7 & 11.0 & 06N21 W23DBDA01 \\
\hline-- & -- & 50 & $\mathrm{D}$ & 1.7 & $08-31-94$ & 50.8 & 6.3 & 14.5 & 06N21W23DDAA01 \\
\hline $10-20-95$ & 8.14 & -- & - & -- & $08-31-94$ & 51.7 & 6.3 & 12.5 & 06N21 W23DDAD01 \\
\hline $10-20-95$ & 4.69 & 50 & D & 1.9 & $08-31-94$ & 51.4 & 6.3 & 10.0 & 06N21W23DDBB01 \\
\hline $10-20-95$ & 3.52 & 40 & D & 1.3 & $08-31-94$ & 73.3 & 6.6 & 10.0 & 06N21 W23DDCB01 \\
\hline $10-20-95$ & 4.38 & - & - & -- & $08-31-94$ & 59.2 & 6.2 & 11.0 & 06N21 W23DDDA01 \\
\hline $10-20-95$ & 17.71 & 7 & D & .4 & $10-25-94$ & 92.9 & 6.6 & 9.0 & 06N21W24BAAC01 \\
\hline $10-20-95$ & 54.92 & -- & - & -- & $04-19-95$ & 175 & 9.4 & 11.0 & 06N21 W24BDCC01 \\
\hline $10-20-95$ & 20.83 & 15 & D & .9 & $08-31-94$ & 63.3 & 6.2 & 12.5 & 06N21W24CCAC01 \\
\hline $08-31-94$ & 9.36 & - & - & -- & $08-31-94$ & 60.2 & 6.3 & 14.0 & 06N21 W24CCBB01 \\
\hline $10-20-95$ & 7.41 & 15 & D & 15.0 & $08-31-94$ & 57.3 & 6.5 & 14.5 & 06N21 W24CCBB02 \\
\hline-- & -- & 15 & $\mathrm{R}$ & -- & $08-30-94$ & 69.3 & 6.3 & 11.0 & 06N21 W24CCCB01 \\
\hline- & -- & 480 & $\mathbf{R}$ & -- & $12-14-95$ & 293 & 7.2 & 12.0 & 06N21 W25DBAA01 \\
\hline $10-20-95$ & 35.98 & 40 & D & 4.0 & $08-19-94$ & 90.3 & 6.6 & 10.0 & 06N21W26AADD01 \\
\hline $10-20-95$ & 36.58 & 8 & D & .1 & $08-18-94$ & 212 & 7.2 & 11.5 & 06N21 W26ABAD01 \\
\hline $10-20-95$ & 34.54 & -- & - & -- & $08-30-94$ & 45.3 & 6.3 & 10.5 & 06N21W26BBCA01 \\
\hline $10-20-95$ & 15.14 & - & - & - & $08-30-94$ & 97.9 & 6.7 & 11.5 & 06N21 W26CBAB01 \\
\hline $12-19-95$ & 31.37 & 10 & D & .2 & -- & -- & - & -- & 06N21W26DBAD01 \\
\hline $10-20-95$ & 37.74 & 30 & D & .3 & $09-13-94$ & 107 & 7.2 & 13.0 & 06N21W26DBDD01 \\
\hline $10-20-95$ & 44.38 & 20 & D & 1.7 & $08-29-94$ & 108 & 6.4 & 10.0 & 06N21 W27ADBC01 \\
\hline $10-20-95$ & 66.34 & 5 & D & -- & $08-30-94$ & 99.2 & 6.7 & 12.0 & 06N21 W27BABA01 \\
\hline $12-19-95$ & 81.27 & 9 & D & .8 & $08-15-95$ & 83.9 & 7.8 & 11.0 & 06N21 W27BBAA01 \\
\hline $08-04-95$ & 16.46 & -- & - & -- & 08-04-95 & 100 & 6.6 & 11.0 & 06N21 W34ABCD01 \\
\hline
\end{tabular}


Table 4. Records of selected wells (Continued)

\begin{tabular}{|c|c|c|c|c|c|c|c|c|c|}
\hline Location number & $\begin{array}{l}\text { Altitude of } \\
\text { land } \\
\text { surface } \\
\text { (ft) }\end{array}$ & $\begin{array}{c}\text { Geologic } \\
\text { unit }\end{array}$ & $\begin{array}{c}\text { Depth of } \\
\text { well } \\
\text { (ft) }\end{array}$ & $\begin{array}{l}\text { Casing } \\
\text { diameter } \\
\text { (in.) }\end{array}$ & $\begin{array}{c}\text { Type of } \\
\text { finish }\end{array}$ & $\begin{array}{l}\text { Depth to } \\
\text { top } \\
\text { of open } \\
\text { interval }\end{array}$ & $\begin{array}{c}\text { Well } \\
\text { completion } \\
\text { date }\end{array}$ & $\begin{array}{l}\text { Type of log } \\
\text { available }\end{array}$ & $\begin{array}{c}\text { Primary } \\
\text { use of } \\
\text { water }\end{array}$ \\
\hline 06N20W01BABA01 & 3,830 & Taf & 45 & 6.0 & $\overline{0}$ & - & $04-18-69$ & $\mathrm{D}$ & $\mathbf{H}$ \\
\hline 06N20W01BABB01 & 3,810 & Taf & 265 & 6.0 & $\mathbf{P}$ & 40 & $03-10-78$ & $\mathrm{D}$ & $\mathbf{H}$ \\
\hline 06N20W01CDCD01 & 3,845 & $\mathrm{TYb}$ & 120 & 8.0 & $\mathrm{P}$ & 20 & $06-21-79$ & D & $\mathbf{H}$ \\
\hline 06N20W02AADC01 & 3,765 & TYb & 115 & 6.0 & $\mathbf{P}$ & 50 & $08-03-91$ & D & $\mathbf{H}$ \\
\hline 06N20W02BBDA01 & 3,679 & Taf & - & -- & - & - & -- & - & $\mathbf{H}$ \\
\hline 06N20W02CCAA01 & 3,682 & Qaf & -- & -- & - & -- & - & - & $\mathbf{H}$ \\
\hline 06N20W02DCDC01 & 3,735 & TYb & 25 & 6.0 & - & -- & $00-00-20$ & - & $\mathbf{H}$ \\
\hline 06N20W03BDBB01 & 3,570 & Tabr & 43 & 6.0 & $\mathbf{P}$ & 36 & $07-10-73$ & D & $\mathbf{H}$ \\
\hline 06N20W03BDCC01 & 3,585 & Qaf & -- & -- & - & - & -- & - & $\mathrm{H}$ \\
\hline 06N20W03CCDB01 & 3,625 & Tabr & - & - & - & -- & -- & - & $\mathbf{H}$ \\
\hline 06N20W04AABC01 & 3,528 & Qaf & 34 & 6.0 & 0 & -- & $01-04-75$ & $\mathrm{D}$ & $\mathbf{H}$ \\
\hline 06N20W04ACCD01 & 3,545 & Tabr & 55 & 6.0 & $\mathrm{O}$ & -- & $03-04-93$ & $\mathrm{D}$ & $\mathbf{H}$ \\
\hline 06N20W04ADCD01 & 3,542 & Tabr & 100 & 6.0 & $\mathrm{O}$ & -- & $05-09-77$ & D & $\mathbf{H}$ \\
\hline 06N20W04CCCD01 & 3,504 & Tabr & 50 & 6.0 & $\mathrm{O}$ & -- & $04-06-83$ & D & $\mathbf{H}$ \\
\hline 06N20W04DCCB01 & 3,562 & Tabr & 58 & 6.0 & $\mathbf{P}$ & 50 & $12-13-91$ & D & $\mathrm{H}$ \\
\hline 06N20W09BDDD01 & 3,578 & Tabr & 125 & 6.0 & - & - & -- & - & $\mathrm{H}$ \\
\hline 06N20W09CBCC01 & 3,562 & Tabr & 90 & - & - & - & -- & - & $\mathbf{H}$ \\
\hline 06N20W09CCDB01 & 3,585 & Tabr & 99 & 6.0 & O & - & $08-01-90$ & D & $\mathrm{H}$ \\
\hline 06N20W09DCAB01 & 3,585 & Tabr & -- & -- & - & -- & -- & - & $\mathbf{H}$ \\
\hline 06N20W10AADC01 & 3,722 & Taf & 160 & 6.0 & $\mathbf{P}$ & 130 & $05-27-88$ & D & $\mathbf{H}$ \\
\hline 06N20W10ABDB01 & 3,705 & Taf & 66 & 6.0 & $\mathbf{P}$ & 47 & $04-28-87$ & D & $\mathrm{H}$ \\
\hline 06N20W10BCAC01 & 3,690 & Taf & 167 & 6.0 & $\mathrm{O}$ & - & -- & D & $\mathbf{H}$ \\
\hline 06N20W 10CACB01 & 3,722 & Taf & 200 & 6.0 & $\mathrm{O}$ & -- & $11-07-74$ & D & $\mathbf{H}$ \\
\hline 06N20W10DADD01 & 3,772 & Taf & 60 & 6.0 & - & -- & -- & - & $\mathrm{H}$ \\
\hline 06N20W10DBBB01 & 3,730 & Taf & 46 & 6.0 & $\mathbf{P}$ & 38 & 07-07-93 & D & $\mathbf{H}$ \\
\hline 06N20W10DCAB01 & 3,742 & Taf & 68 & 6.0 & - & -- & - & - & $\mathrm{H}$ \\
\hline 06N20W11CCBD01 & 3,788 & Taf & 174 & 6.0 & $\mathrm{~S}$ & 111 & $04-27-95$ & D & $\mathbf{H}$ \\
\hline 06N20W11DBAA01 & 3,790 & Taf & 135 & 6.0 & $\mathbf{P}$ & 95 & $11-22-77$ & D & $\mathbf{H}$ \\
\hline 06N20W12ABDB01 & 3,875 & Qaf & 22 & -- & - & -- & -- & - & $\mathbf{H}$ \\
\hline 06N20W12CCCD01 & 3,883 & Taf & 63 & 6.0 & O & - & $09-26-73$ & $\mathrm{D}$ & I \\
\hline 06N20W13BADD01 & 3,945 & $\mathrm{TYb}$ & 35 & -- & - & -- & -- & - & $\mathrm{H}$ \\
\hline 06N20W13BCAC01 & 3,948 & Taf & - & -- & - & -- & -- & - & $\mathrm{H}$ \\
\hline 06N20W14ACDD01 & 3,884 & Taf & 120 & 6.0 & $\mathbf{P}$ & 80 & $03-22-83$ & D & $\mathrm{S}$ \\
\hline 06N20W14BADB01 & 3,842 & Taf & 80 & 6.0 & $\mathbf{P}$ & 50 & $06-24-76$ & D & $\mathbf{H}$ \\
\hline 06N20W14BBBB01 & 3,792 & Tabr & 1,110 & 4.0 & $\mathbf{P}$ & 209 & 04-06-79 & D & $\mathrm{U}$ \\
\hline 06N20W14CAAA01 & 3,830 & Taf & 78 & 6.0 & $\mathrm{~S}$ & 54 & $05-13-93$ & D & $\mathrm{H}$ \\
\hline 06N20W14CDAB01 & 3,775 & Taf & 75 & 6.0 & - & - & $00-00-82$ & - & $\mathrm{H}$ \\
\hline 06N20W14DAAA01 & 3,922 & Taf & -- & - & - & - & $00-00-79$ & - & $\mathrm{H}$ \\
\hline 06N20W15AACD01 & 3,750 & Taf & 65 & -- & - & -- & -- & - & $\mathbf{H}$ \\
\hline 06N20W15BBCC01 & 3,640 & Tabr & - & -- & - & -- & -- & - & $\mathrm{H}$ \\
\hline 06N20W15CACC01 & 3,694 & Taf & 59 & 6.0 & $\mathrm{~S}$ & 34 & $05-13-93$ & D & $\mathrm{H}$ \\
\hline 06N20W16AABD01 & 3,591 & Tabr & 74 & 6.0 & $\mathrm{O}$ & -- & $06-23-77$ & D & $\mathrm{H}$ \\
\hline 06N20W16ACCB01 & 3,622 & Tabr & 150 & 6.0 & $\mathbf{P}$ & 120 & $08-28-79$ & D & $\mathrm{H}$ \\
\hline 06N20W 16ADCB01 & 3,672 & Tabr & 110 & 6.0 & 0 & -- & $01-12-78$ & D & $\mathbf{S}$ \\
\hline 06N20W16BAAD01 & 3,626 & Tabr & 180 & 6.0 & $\mathbf{P}$ & 140 & 04-07-78 & D & $\mathrm{H}$ \\
\hline
\end{tabular}




\begin{tabular}{|c|c|c|c|c|c|c|c|c|c|}
\hline \multicolumn{2}{|c|}{ Water level } & \multirow[b]{2}{*}{$\begin{array}{c}\text { Yield } \\
\text { (gal/min) }\end{array}$} & \multirow[b]{2}{*}{$\begin{array}{l}\text { Source of } \\
\text { yield } \\
\text { data }\end{array}$} & \multirow{2}{*}{$\begin{array}{c}\text { Specific } \\
\text { capacity } \\
{\left[\begin{array}{c}\text { [(gal/min)/ } \\
\text { ft }]\end{array}\right.}\end{array}$} & \multirow{2}{*}{$\begin{array}{c}\text { Date of field } \\
\text { water- } \\
\text { quality } \\
\text { parameter } \\
\text { measurement }\end{array}$} & \multirow{2}{*}{$\begin{array}{c}\text { Specific } \\
\text { conduct- } \\
\text { ance, } \\
\text { field } \\
(\mu \mathrm{S} / \mathrm{cm})\end{array}$} & \multirow{2}{*}{$\begin{array}{c}\mathrm{pH}, \\
\text { field } \\
\text { (stand- } \\
\text { ard units) }\end{array}$} & \multirow{2}{*}{$\begin{array}{l}\text { Water } \\
\text { temper- } \\
\text { ature, } \\
\text { field } \\
\left({ }^{\circ} \mathrm{C}\right) \\
\end{array}$} & \multirow[b]{2}{*}{ Location number } \\
\hline $\begin{array}{c}\text { Date of } \\
\text { measure- } \\
\text { ment }\end{array}$ & $\begin{array}{l}\text { Depth to } \\
\text { water } \\
\text { (ft) }\end{array}$ & & & & & & & & \\
\hline $08-24-95$ & 8.08 & 3 & $\mathrm{D}$ & .1 & -- & - & -- & - & 06N20W01BABA01 \\
\hline $11-10-95$ & 13.20 & 2 & $\mathrm{D}$ & -- & $07-26-95$ & 396 & 8.0 & 14.5 & 06N20W01BABB01 \\
\hline $11-10-95$ & 4.55 & 15 & $\mathrm{D}$ & .2 & 06-14-95 & 395 & 7.4 & 10.5 & 06N20W01CDCD01 \\
\hline $11-10-95$ & 45.25 & 3 & $\mathrm{D}$ & -- & $07-24-95$ & 453 & 7.3 & 15.0 & 06N20W02AADC01 \\
\hline $11-10-95$ & 7.93 & -- & - & -- & $07-11-95$ & 661 & 7.9 & 12.5 & 06N20W02BBDA01 \\
\hline $07-27-95$ & 1.34 & -- & - & -- & $07-26-95$ & 558 & 7.6 & 10.5 & 06N20W02CCAA01 \\
\hline $11-10-95$ & 8.23 & -- & - & - & $07-12-95$ & 532 & 7.5 & 12.0 & 06N20W02DCDC01 \\
\hline $11-10-95$ & 17.52 & 25 & D & 1.1 & $07-24-95$ & 328 & 7.7 & 12.0 & 06N20W03BDBB01 \\
\hline $12-19-95$ & 23.68 & -- & - & -- & $07-12-95$ & 505 & 7.2 & 11.5 & 06N20W03BDCC01 \\
\hline-- & -- & -- & - & $\cdots$ & $05-04-95$ & 463 & 7.6 & 10.5 & 06N20W03CCDB01 \\
\hline $11-10-95$ & 7.26 & 12 & D & -- & $07-24-95$ & 449 & 7.3 & 11.5 & 06N20W04AABC01 \\
\hline $11-10-95$ & 34.02 & 15 & D & -- & $07-27-95$ & 385 & 7.4 & 12.5 & 06N20W04ACCD01 \\
\hline $06-14-95$ & 24.93 & 8 & D & .2 & $06-14-95$ & 359 & 7.6 & 12.0 & 06N20W04ADCD01 \\
\hline $11-10-95$ & 19.67 & 50 & D & 2.2 & $05-04-95$ & 363 & 7.5 & 10,5 & 06N20W04CCCD01 \\
\hline $11-10-95$ & 35.00 & 18 & D & 1.5 & $06-14-95$ & 436 & 7.5 & 13.0 & 06N20W04DCCB01 \\
\hline $11-10-95$ & 49.44 & -- & - & -- & $07-26-95$ & 595 & 7.4 & 12.0 & 06N20W09BDDD01 \\
\hline $11-10-95$ & 60.35 & -- & - & -- & 08-03-95 & 332 & 7.5 & 13.0 & 06N20W09CBCC01 \\
\hline $11-10-95$ & 67.74 & 20 & D & -- & $05-02-95$ & 375 & 7.5 & 12.5 & 06N20W09CCDB01 \\
\hline $11-10-95$ & 36.00 & -- & - & -- & $05-03-95$ & 588 & 7.2 & 12.0 & 06N20W09DCAB01 \\
\hline $11-10-95$ & 27.80 & 15 & D & .1 & $07-12-95$ & 775 & 7.6 & 12.5 & 06N20W10AADC01 \\
\hline $11-10-95$ & 15.68 & 35 & D & 1.5 & $05-04-95$ & 419 & 8.0 & 10.0 & 06N20W10ABDB01 \\
\hline- & -- & -- & - & $-\cdots$ & $07-12-95$ & 429 & 7.8 & 12.0 & 06N20W10BCAC01 \\
\hline $11-10-95$ & 137.32 & 20 & D & .7 & $06-14-95$ & 600 & 7.9 & 13.0 & 06N20W10CACB01 \\
\hline-- & -- & 20 & $\mathrm{O}$ & -- & $07-25-95$ & 420 & 7.7 & 13.0 & 06N20W10DADD01 \\
\hline $11-10-95$ & 18.22 & 10 & D & .8 & $07-25-95$ & 411 & 7.9 & 12.0 & 06N20W 10DBBB01 \\
\hline $11-10-95$ & 22.24 & -- & - & - & $07-25-95$ & 384 & 8.0 & 10.5 & 06N20W10DCAB01 \\
\hline-- & - & 30 & D & .3 & $06-13-95$ & 598 & 7.8 & 12.5 & 06N20W11CCBD01 \\
\hline $05-03-95$ & 43.24 & 20 & D & .4 & $05-03-95$ & 582 & 7.5 & 11.5 & 06N20W11DBAA01 \\
\hline $06-14-95$ & 6.48 & -- & - & - & $06-14-95$ & 232 & 7.8 & 11.0 & 06N20W12ABDB01 \\
\hline $11-10-95$ & 29.54 & 10 & $\mathrm{D}$ & .3 & $05-04-95$ & 750 & 7.6 & 11.5 & 06N20W12CCCD01 \\
\hline-- & - & -- & - & -- & $06-13-95$ & 864 & 7.3 & 12.0 & 06N20W13BADD01 \\
\hline-- & - & -- & - & -- & $07-12-95$ & 637 & 7.6 & 12.5 & 06N20W13BCAC01 \\
\hline-- & -- & 25 & $\mathrm{D}$ & .6 & $05-03-95$ & 578 & 7.6 & 9.5 & 06N20W14ACDD01 \\
\hline $11-10-95$ & 14.21 & 20 & D & .6 & $05-02-95$ & 440 & 7.6 & 11.0 & 06N20W14BADB01 \\
\hline $12-19-95$ & 66.80 & 32 & D & .7 & - & -- & -- & -- & 06N20W14BBBB01 \\
\hline $11-10-95$ & 15.56 & 20 & $\mathrm{D}$ & .5 & $06-12-95$ & 248 & 7.3 & 10.0 & 06N20W 14CAAA01 \\
\hline $08-01-95$ & flowing & -- & - & -- & $08-01-95$ & 555 & 7.5 & 14.5 & 06N20W 14CDAB01 \\
\hline $08-21-95$ & 94.59 & -- & - & -- & $08-21-95$ & 517 & 8.1 & 18.0 & 06N20W14DAAA01 \\
\hline $11-10-95$ & 30.62 & -- & - & -- & $06-13-95$ & 580 & 7.6 & 12.0 & 06N20W15AACD01 \\
\hline $11-10-95$ & 61.15 & $\cdots$ & - & - & $05-04-95$ & 481 & 7.5 & 11.5 & 06N20W15BBCC01 \\
\hline $11-10-95$ & 21.73 & 20 & D & .9 & $07-25-95$ & 505 & 7.5 & 11.5 & 06N20W15CACC01 \\
\hline- & - & 35 & D & 1.8 & 08-03-95 & 526 & 7.5 & 15.0 & 06N20W 16AABD01 \\
\hline $11-10-95$ & 74.80 & 10 & D & .2 & $05-02-95$ & 484 & 7.5 & 11.5 & 06N20W16ACCB01 \\
\hline $11-10-95$ & 73.19 & 10 & $\mathrm{D}$ & .3 & $07-27-95$ & 577 & 7.5 & 14.5 & 06N20W16ADCB01 \\
\hline $11-10-95$ & 87.33 & 15 & $\mathrm{D}$ & .2 & 05-04-95 & 364 & 7.5 & 10.0 & 06N20W16BAAD01 \\
\hline
\end{tabular}


Table 4. Records of selected wells (Continued)

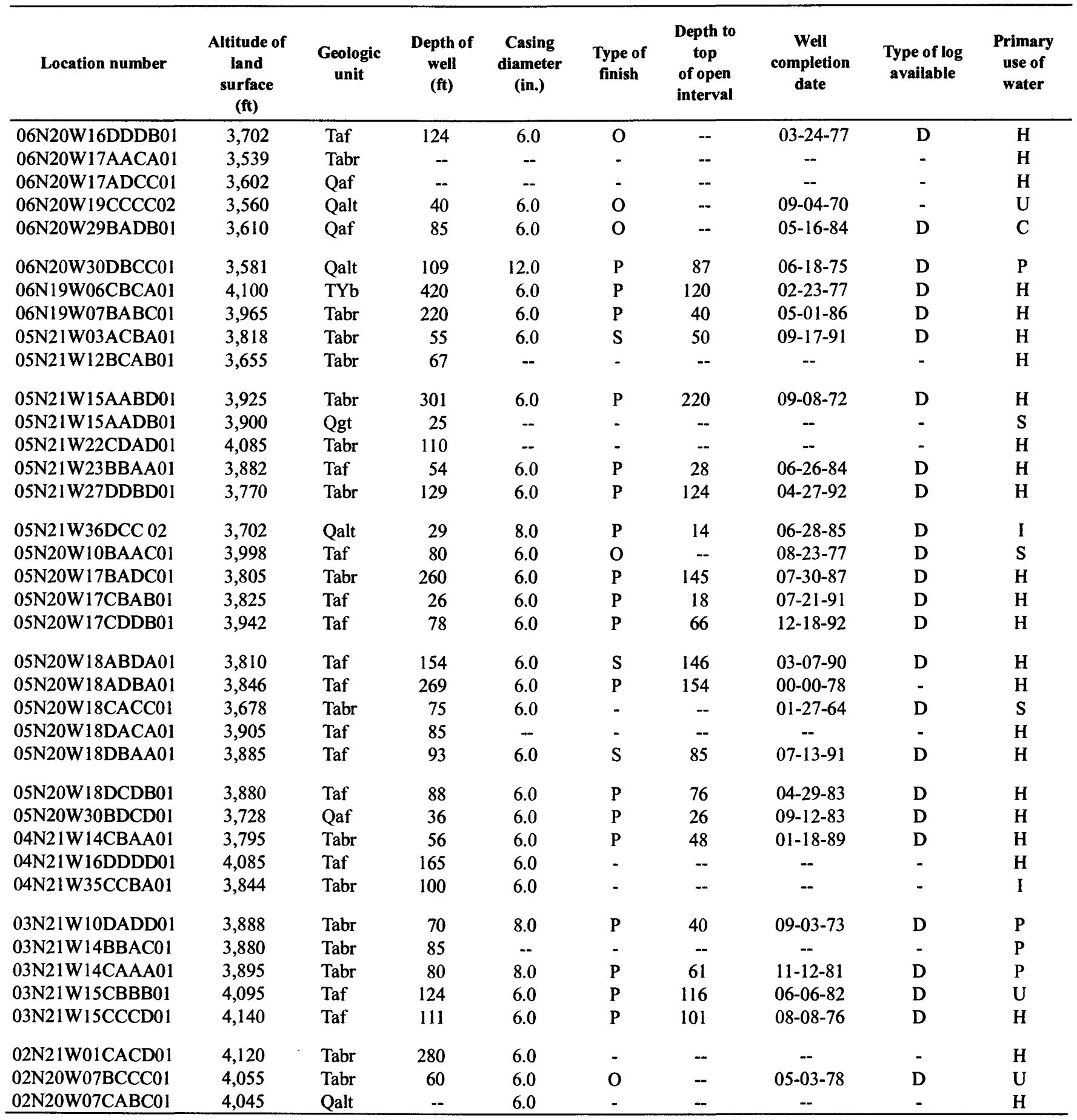




\begin{tabular}{|c|c|c|c|c|c|c|c|c|c|}
\hline \multicolumn{2}{|c|}{ Water level } & \multirow[b]{2}{*}{$\begin{array}{c}\text { Yield } \\
\text { (gal/min) }\end{array}$} & \multirow[b]{2}{*}{$\begin{array}{l}\text { Source of } \\
\text { yield } \\
\text { data }\end{array}$} & \multirow{2}{*}{$\begin{array}{c}\text { Specific } \\
\text { capacity } \\
{[(\mathrm{gal} / \mathrm{min}) /} \\
\mathrm{ft}]\end{array}$} & \multirow{2}{*}{$\begin{array}{c}\text { Date of field } \\
\text { water- } \\
\text { quality } \\
\text { parameter } \\
\text { measurement }\end{array}$} & \multirow{2}{*}{$\begin{array}{c}\text { Specific } \\
\text { conduct- } \\
\text { ance, } \\
\text { field } \\
(\mu \mathrm{S} / \mathrm{cm}) \\
\end{array}$} & \multirow{2}{*}{$\begin{array}{c}\text { pH, } \\
\text { field } \\
\text { (stand- } \\
\text { ard units) }\end{array}$} & \multirow{2}{*}{$\begin{array}{c}\text { Water } \\
\text { temper- } \\
\text { ature, } \\
\text { field } \\
\left({ }^{\circ} \mathrm{C}\right) \\
\end{array}$} & \multirow[b]{2}{*}{ Location number } \\
\hline $\begin{array}{c}\text { Date of } \\
\text { measure- } \\
\text { ment }\end{array}$ & $\begin{array}{l}\text { Depth to } \\
\text { water } \\
\text { (ft) }\end{array}$ & & & & & & & & \\
\hline-- & -- & 75 & D & .8 & $05-03-95$ & 453 & 7.5 & 9.5 & 06N20W16DDDB01 \\
\hline -- & -- & -- & - & - & $05-03-95$ & 284 & 6.9 & 10.0 & 06N20W17AACA01 \\
\hline $05-02-95$ & 69.97 & -- & - & -- & $05-02-95$ & 307 & 7.2 & 10.5 & 06N20W17ADCC01 \\
\hline $12-13-95$ & 12.09 & -- & - & -- & -- & -- & -- & -- & 06N20W19CCCC02 \\
\hline $12-19-95$ & 16.81 & 40 & D & 1.0 & $08-21-95$ & 409 & 7.8 & 12.5 & 06N20W29BADB01 \\
\hline $07-16-91$ & 4.97 & 500 & D & 6.9 & -- & -- & -- & -- & 06N20W30DBCC01 \\
\hline $07-27-95$ & 229.51 & 9 & D & -- & $07-27-95$ & 739 & 7.0 & 14.5 & 06N19W06CBCA01 \\
\hline $12-19-95$ & 28.88 & 10 & D & .1 & $07-26-95$ & 391 & 7.6 & 12.0 & 06N19W07BABC01 \\
\hline $08-04-95$ & 24.38 & 20 & D & .7 & $08-04-95$ & 106 & 6.3 & 9.0 & 05N21W03ACBA01 \\
\hline $12-12-95$ & 50.05 & -- & - & -- & $08-03-95$ & 42.1 & 6.4 & 11.0 & $05 \mathrm{~N} 2$ IW $12 \mathrm{BCAB} 01$ \\
\hline $07-15-91$ & 156.96 & 16 & D & .1 & $12-14-95$ & 158 & 8.0 & 11.0 & 05N21W15AABD01 \\
\hline $12-14-95$ & 8.21 & 5 & $\mathrm{~S}$ & -- & $12-14-95$ & 40.3 & 6.8 & 7.5 & $05 \mathrm{~N} 21 \mathrm{~W} 15 \mathrm{AADB} 01$ \\
\hline $08-03-95$ & 91.76 & -- & - & -- & $08-03-95$ & 95.8 & 7.3 & 13.5 & 05N21W22CDAD01 \\
\hline $12-12-95$ & 17.04 & 5 & D & .2 & $08-03-95$ & 40.0 & 6.3 & 11.5 & 05N21W23BBAA01 \\
\hline $08-03-95$ & 20.50 & 30 & D & .3 & 08-03-95 & 108 & 6.6 & 11.5 & 05N21W27DDBD0I \\
\hline $06-04-96$ & 4.65 & 99 & D & 9.0 & $06-04-96$ & 102 & 6.4 & 7.5 & 05N21W36DCC 02 \\
\hline $12-12-95$ & 25.98 & 20 & D & .7 & $12-12-95$ & 622 & 7.9 & 9.0 & 05N20W10BAAC01 \\
\hline 08-02-95 & 26.29 & 12 & D & .1 & $08-02-95$ & 424 & 7.8 & 13.5 & 05N20W17BADC01 \\
\hline $08-02-95$ & 2.11 & 18 & D & 1.8 & $08-02-95$ & 427 & 7.1 & 15.0 & 05N20W17CBAB01 \\
\hline $08-21-95$ & 36.64 & 16 & D & .7 & $08-21-95$ & 435 & 8.0 & 11.0 & 05N20W17CDDB01 \\
\hline $08-02-95$ & 120.49 & 20 & D & .8 & $08-02-95$ & 426 & 7.7 & 14.5 & 05N20W18ABDA01 \\
\hline -- & -- & -- & - & -- & $08-02-95$ & 415 & 7.5 & 13.5 & 05N20W18ADBA01 \\
\hline $12-14-95$ & 50.20 & 30 & 0 & -- & $12-14-95$ & 244 & 7.2 & 10.0 & 05N20W18CACC01 \\
\hline $08-02-95$ & 26.65 & -- & - & -- & $08-02-95$ & 310 & 7.8 & 12.5 & $05 \mathrm{~N} 20 \mathrm{~W} 18 \mathrm{DACA} 01$ \\
\hline $08-02-95$ & 70.00 & 12 & D & .6 & $08-02-95$ & 288 & 7.6 & 11.5 & 05N20W18DBAA01 \\
\hline $08-02-95$ & 57.76 & 9 & D & .5 & $08-02-95$ & 243 & 7.7 & 13.0 & $05 \mathrm{~N} 20 \mathrm{~W} 18 \mathrm{DCDB} 01$ \\
\hline $12-19-95$ & 22.42 & 100 & D & 7.7 & $12-14-95$ & 188 & 6.8 & 10.0 & 05N20W30BDCD01 \\
\hline $12-13-95$ & 30.79 & 30 & D & 2.8 & $12-13-95$ & 284 & 6.8 & 10.0 & 04N21W14CBAA01 \\
\hline $12-13-95$ & 66.24 & 8 & $\mathrm{~s}$ & .4 & $12-13-95$ & 70.4 & 6.8 & 10.0 & 04N21W16DDDD01 \\
\hline $07-12-91$ & 10.92 & -- & - & -- & -- & -- & -- & -- & 04N21W35CCBA01 \\
\hline $07-12-91$ & 11.77 & 500 & D & -- & -- & -- & - & -- & 03N21W10DADD01 \\
\hline-- & -- & -- & - & -- & $08-19-92$ & 159 & 6.5 & 10.5 & $03 \mathrm{~N} 21 \mathrm{~W} 14 \mathrm{BBAC} 01$ \\
\hline $07-12-91$ & 7.53 & 250 & D & -- & -- & -- & -- & -- & 03N21W14CAAA01 \\
\hline $12-19-95$ & 69.84 & 10 & D & .1 & -- & -- & -- & -- & $03 \mathrm{~N} 21 \mathrm{IW} 15 \mathrm{CBBB} 01$ \\
\hline $06-04-96$ & 68.11 & 8 & D & .3 & $06-04-96$ & 151 & 6.8 & 9.5 & 03N2IW15CCCD01 \\
\hline $12-19-95$ & 24.00 & -- & - & -- & $12-13-95$ & 215 & 7.1 & 9.5 & 02N21W01CACD01 \\
\hline $07-11-91$ & 29.48 & 20 & D & 1.0 & -- & -- & -- & -- & 02N20W07BCCC01 \\
\hline $12-13-95$ & 35.65 & -- & - & -- & $12-13-95$ & 69.9 & 6.8 & 9.0 & $02 \mathrm{~N} 20 \mathrm{~W} 07 \mathrm{CABC} 01$ \\
\hline
\end{tabular}


Table 5. Records of water levels in wells

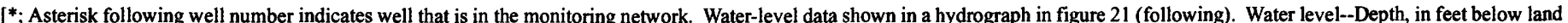

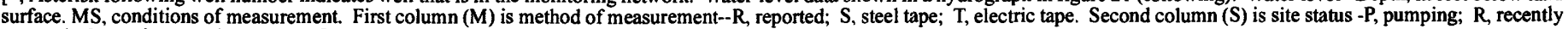
pumped; $S$, nearby pumping; $Z$, other]

\section{N20W10CBBD01}

$\begin{array}{ccc} & \text { WATER } & \\ \text { DATE } & \text { LEVEL } & \text { MS } \\ 08-27-93 & 10.16 & \mathrm{R} \\ 12-06-93 & 12.27 & \mathrm{R} \\ 03-10-94 & 12.66 & \mathrm{R} \\ 06-16-94 & 7.79 & \mathrm{R} \\ 09-27-94 & 12.19 & \mathrm{R} \\ 12-20-94 & 13.01 & \mathrm{R} \\ 03-23-95 & 12.27 & \mathrm{R} \\ 06-27-95 & 9.14 & \mathrm{R} \\ 09-28-95 & 11.70 & \mathrm{R} \\ 12-19-95 & 11.39 & \mathrm{R} \\ 03-14-96 & 10.65 & \mathrm{R} \\ 06-18-96 & 7.12 & \mathrm{R} \\ 09-24-96 & 11.17 & \mathrm{R} \\ 12-19-96 & 11.58 & \mathrm{R} \\ 06-17-97 & 8.93 & \mathrm{R} \\ 09-04-97 & 10.75 & \mathrm{R}\end{array}$

\section{N20W11CDCD01}

$\begin{array}{ccc} & \text { WATER } & \\ \text { DATE } & \text { LEVEL } & \text { MS } \\ 08-26-93 & 48.26 & \mathrm{R} \\ 12-06-93 & 51.82 & \mathrm{R} \\ 03-10-94 & 58.24 & \mathrm{R} \\ 06-16-94 & 52.24 & \mathrm{R} \\ 09-27-94 & 53.17 & \mathrm{R} \\ 03-23-95 & 55.16 & \mathrm{R} \\ 06-27-95 & 47.18 & \mathrm{R} \\ 09-28-95 & 40.16 & \mathrm{R} \\ 12-19-95 & 48.16 & \mathrm{R} \\ 03-14-96 & 52.04 & \mathrm{R} \\ 06-18-96 & 51.73 & \mathrm{R} \\ 12-19-96 & 52.99 & \mathrm{R} \\ 06-17-97 & 46.81 & \mathrm{R} \\ 09-04-97 & 45.81 & \mathrm{R}\end{array}$

\section{N20W12ACDB01*}

$\begin{array}{ccl} & \text { WATER } & \\ \text { DATE } & \text { LEVEL } & \text { MS } \\ 08-22-94 & 25.13 & \mathrm{~S} \\ 10-30-94 & 24.47 & \mathrm{~S} \\ 01-16-95 & 24.37 & \mathrm{~S} \\ 03-31-95 & 24.28 & \mathrm{~S} \\ 06-03-95 & 21.45 & \mathrm{~S} \\ 08-19-95 & 24.37 & \mathrm{~S} \\ 09-22-95 & 24.28 & \mathrm{~S} \\ 11-17-95 & 23.44 & \mathrm{~S} \\ 02-25-96 & 23.22 & \mathrm{SR} \\ 05-16-96 & 20.29 & \mathrm{~S} \\ 07-24-96 & 23.79 & \mathrm{~T} \\ 09-24-96 & 23.84 & \mathrm{~T} \\ 11-19-96 & 24.05 & \mathrm{~S} \\ 01-07-97 & 23.41 & \mathrm{~S} \\ 02-26-97 & 23.79 & \mathrm{~S} \\ 04-03-97 & 40.52 & \mathrm{~S} \\ 05-20-97 & 18.92 & \mathrm{~S} \\ 06-24-97 & 20.99 & \mathrm{~S} \\ 08-19-97 & 23.66 & \mathrm{~S} \\ 10-15-97 & 24.63 & \mathrm{~S}\end{array}$

\section{N20W12ADCB01}

$\begin{array}{ccc} & \text { WATER } & \\ \text { DATE } & \text { LEVEL } & \text { MS } \\ 08-19-95 & 36.52 & \text { S } \\ 11-17-95 & 35.71 & \text { S }\end{array}$

$$
\text { 10N20W12ADCB01 cont. }
$$

$\begin{array}{ccc} & \text { WATER } & \\ \underline{\text { DATE }} & \frac{\text { LEVEL }}{35-46-96} & \underline{\text { MS }} \\ 05-15-96 & 32.80 & \mathrm{~S}\end{array}$

\begin{tabular}{|c|c|c|}
\hline & WATER & \\
\hline DATE & LEVEL & $\underline{\mathrm{MS}}$ \\
\hline $10-30-94$ & 24.04 & $\mathbf{S}$ \\
\hline $01-19-95$ & 23.55 & $\mathbf{S}$ \\
\hline $03-26-95$ & 23.39 & $\mathbf{S}$ \\
\hline $06-03-95$ & 24.20 & $\mathbf{S}$ \\
\hline $08-22-95$ & 25.28 & SR \\
\hline $09-22-95$ & 23.46 & S \\
\hline $11-19-95$ & 23.05 & $\mathbf{S}$ \\
\hline $05-17-96$ & 21.32 & $\mathbf{S}$ \\
\hline
\end{tabular}

\section{N20W12DAAA01}

\begin{tabular}{ccc} 
DATE & $\begin{array}{c}\text { WATER } \\
\text { LEVEL }\end{array}$ & MS \\
\hline $10-25-94$ & $\frac{30.08}{\mathrm{~S}}$ & $\mathrm{~S}$ \\
$01-18-95$ & 30.08 & $\mathrm{~S}$ \\
$03-31-95$ & 29.99 & $\mathrm{~S}$ \\
$06-03-95$ & 30.30 & $\mathrm{~S}$ \\
$08-19-95$ & 30.34 & $\mathrm{~S}$ \\
$09-22-95$ & 29.97 & $\mathrm{~S}$ \\
$11-17-95$ & 29.43 & $\mathrm{~S}$ \\
$02-24-96$ & 28.48 & $\mathrm{~S}$ \\
$05-15-96$ & 27.66 &
\end{tabular}

\section{N20W12DABD01}

\begin{tabular}{|c|c|c|}
\hline & WATER & \\
\hline DATE & LEVEL & $\underline{\text { MS }}$ \\
\hline $08-24-95$ & 33.67 & $\mathbf{S}$ \\
\hline $09-22-95$ & 33.58 & 8 \\
\hline $11-18-95$ & 32.88 & S \\
\hline $02-26-96$ & 32.42 & $\mathrm{~S}$ \\
\hline 05-15-96 & 29.82 & $\mathrm{~S}$ \\
\hline
\end{tabular}

\section{N20W12DADA01*}

\begin{tabular}{|c|c|c|}
\hline & WATER & \\
\hline DATE & LEVEL & $\underline{\mathrm{MS}}$ \\
\hline $08-15-94$ & 30.76 & S \\
\hline $10-30-94$ & 30.66 & $\mathrm{~S}$ \\
\hline $01-18-95$ & 30.43 & S \\
\hline $03-31-95$ & 30.42 & S \\
\hline $06-03-95$ & 30.38 & S \\
\hline $08-19-95$ & 30.34 & S \\
\hline $09-22-95$ & 30.35 & S \\
\hline $11-18-95$ & 30.13 & S \\
\hline $02-25-96$ & 26.73 & S \\
\hline $05-15-96$ & 26.73 & S \\
\hline $07-24-96$ & 36.97 & TP \\
\hline $09-24-96$ & 28.90 & $\mathrm{~T}$ \\
\hline $11-19-96$ & 28.73 & S \\
\hline $01-07-97$ & 28.28 & S \\
\hline $02-26-97$ & 23.53 & S \\
\hline $04-03-97$ & 23.33 & S \\
\hline $05-20-97$ & 24.20 & S \\
\hline $06-24-97$ & 24.49 & S \\
\hline $08-19-97$ & 16.59 & S \\
\hline & & \\
\hline
\end{tabular}

\section{N20W12DDDC01*}

$\begin{array}{ccc}\text { DATE } & \begin{array}{r}\text { WATER } \\ \text { LEVEL }\end{array} & \text { MS } \\ 09-28-94 & 5.69 & \mathrm{~S} \\ 03-31-95 & 5.05 & \mathrm{~S} \\ 06-03-95 & 4.39 & \mathrm{~S} \\ 08-19-95 & 4.87 & \mathrm{~S} \\ 09-15-95 & 4.74 & \mathrm{~S} \\ 11-17-95 & 4.04 & \mathrm{~S} \\ 02-24-96 & 2.84 & \mathrm{~S} \\ 05-17-96 & 1.09 & \mathrm{~S} \\ 07-24-96 & 4.26 & \mathrm{~T} \\ 09-24-96 & 3.19 & \mathrm{~T} \\ 11-19-96 & 2.92 & \mathrm{~S} \\ 01-07-97 & 2.44 & \mathrm{~S} \\ 02-26-97 & 2.29 & \mathrm{~S} \\ 04-03-97 & 1.16 & \mathrm{~S} \\ 05-20-97 & .04 & \mathrm{~S} \\ 06-24-97 & .08 & \mathrm{~S} \\ 08-19-97 & 1.31 & \mathrm{~S} \\ 10-15-97 & .30 & \mathrm{~S}\end{array}$

\section{N20W13BBA 01}

DATE

05-14-59

06-15-59

07-11-59

08-19-59

09-10-59

10-16-59

11-18-59

12-16-59

01-25-60

$02-09-60$

03-06-60

04-11-60

05-02-60

06-17-60

07-24-60

08-25-60

09-05-60

$10-14-60$

$11-14-60$

$12-14-60$

$01-06-61$

02-15-61

03-22-61

04-08-61

05-15-61

06-05-61

07-07-61

$08-12-61$

09-05-61

10-10-61

$11-22-61$

12-06-61

01-10-62

02-15-62

03-16-62

04-27-62

05-26-62

$06-17-62$

07-24-62

08-15-62

09-17-62

10-16-62

$11-19-62$

12-20-62

01-10-63

03-19-63

WATER

LEVEL MS

$\begin{array}{ll}5.42 & -- \\ 2.48 & - \\ 4.64 & - \\ 5.60 & - \\ 4.79 & - \\ 4.52 & - \\ 5.69 & - \\ 5.95 & - \\ 6.49 & - \\ 6.39 & - \\ 6.89 & - \\ 5.54 & - \\ 6.05 & - \\ 3.21 & - \\ 5.56 & - \\ 5.27 & - \\ 4.90 & - \\ 5.19 & - \\ 6.50 & - \\ 6.78 & - \\ 6.95 & - \\ 6.47 & - \\ 6.78 & - \\ 6.38 & - \\ 6.00 & - \\ 3.04 & - \\ 4.87 & - \\ 6.00 & - \\ 5.00 & - \\ 6.08 & - \\ 6.37 & - \\ 6.20 & - \\ 6.24 & - \\ 6.00 & - \\ 6.69 & - \\ 5.09 & - \\ 4.09 & - \\ 3.70 & - \\ 5.24 & - \\ 5.43 & - \\ 4.60 & - \\ 4.50 & - \\ 6.01 & - \\ 5.50 & - \\ 6.23 & - \\ 6.29 & -\end{array}$


Table 5. Records of water levels in wells (Continued)

10N20W13BBA 01 cont.

\begin{tabular}{|c|c|c|c|c|c|}
\hline & WATER & & \multicolumn{3}{|c|}{ WATER } \\
\hline DATE & LEVEL & $\underline{\text { MS }}$ & DATE & LEVEL & $\underline{\text { MS }}$ \\
\hline $04-15-63$ & 6.40 & - & $10-03-91$ & 6.26 & - \\
\hline $05-24-63$ & 4.05 & -- & $11-12-91$ & 6.36 & -- \\
\hline $06-05-63$ & 3.38 & -- & $02-04-92$ & 6.55 & $\mathbf{S}$ \\
\hline $07-01-63$ & 4.22 & -- & $05-06-92$ & 5.45 & $\mathbf{S}$ \\
\hline $07-23-63$ & 5.41 & -- & 06-17-92 & 5.39 & $\mathbf{S}$ \\
\hline 09-06-63 & 5.23 & -- & $07-29-92$ & 6.25 & $\mathbf{S}$ \\
\hline $10-01-63$ & 6.07 & - & $10-19-92$ & 6.32 & $\mathrm{~s}$ \\
\hline $11-04-63$ & 6.32 & -- & $01-12-93$ & 6.63 & $\mathrm{~S}$ \\
\hline $12-03-63$ & 6.34 & -- & 04-06-93 & 6.18 & -- \\
\hline $03-13-64$ & 7.03 & -- & $08-13-93$ & 6.00 & $\mathbf{S}$ \\
\hline $03-05-65$ & 5.96 & -- & $10-21-93$ & 5.86 & $\mathbf{S}$ \\
\hline 09-03-65 & 5.00 & -. & $02-02-94$ & 6.42 & $\mathbf{S}$ \\
\hline 03-08-66 & 6.55 & - & 06-01-94 & 4.86 & $\mathbf{S}$ \\
\hline $09-07-66$ & 5.26 & - & $10-04-94$ & 6.39 & $\mathbf{S}$ \\
\hline $11-30-66$ & 6.50 & -- & $12-27-94$ & 6.52 & $\mathrm{~S}$ \\
\hline $03-06-67$ & 6.70 & -- & $05-10-95$ & 5.86 & $\mathbf{S}$ \\
\hline $06-05-67$ & 3.75 & -- & $07-05-95$ & 5.54 & $\mathbf{S}$ \\
\hline $09-11-67$ & 6.44 & - & $07-25-95$ & 5.54 & $\mathbf{S}$ \\
\hline $11-30-67$ & 6.10 & -- & $10-18-95$ & 5.62 & $\mathrm{~S}$ \\
\hline 03-07-68 & 5.94 & -- & $12-13-95$ & 4.95 & $\mathbf{S}$ \\
\hline $05-28-68$ & 4.92 & -- & $02-13-96$ & 4.70 & $\mathrm{~S}$ \\
\hline $08-21-68$ & 5.30 & -- & 05-16-96 & 4.28 & $\mathrm{~S}$ \\
\hline $12-11-68$ & 5.79 & -- & $08-08-96$ & 5.91 & $\mathrm{~S}$ \\
\hline $06-10-69$ & 4.00 & -- & $10-04-96$ & 6.12 & $\mathbf{S}$ \\
\hline 09-04-69 & 6.31 & -- & $11-26-96$ & 6.23 & $\mathrm{~S}$ \\
\hline $12-16-69$ & 6.47 & -- & 01-07-97 & 5.49 & $\mathbf{S}$ \\
\hline $03-11-70$ & 6.19 & -- & $12-13-95$ & 4.95 & -- \\
\hline $06-24-70$ & 3.85 & - & $02-19-97$ & 6.15 & $\mathbf{S}$ \\
\hline $11-12-70$ & 5.82 & -- & 04-15-97 & 5.52 & $\mathbf{S}$ \\
\hline $02-17-71$ & 5.82 & -- & $06-19-97$ & 3.46 & $\mathbf{S}$ \\
\hline $06-02-71$ & 3.21 & -- & 08-20-97 & 5.87 & $\mathrm{~S}$ \\
\hline $09-13-71$ & 5.67 & -- & $10-16-97$ & 5.68 & $\mathbf{S}$ \\
\hline $12-21-71$ & 6.59 & - & & & \\
\hline $03-13-72$ & 5.57 & -- & \multicolumn{3}{|c|}{$10 \mathrm{~N} 19 \mathrm{~W} 05 \mathrm{CCCC} 01$} \\
\hline $06-26-72$ & 3.66 & -- & \multirow{2}{*}{\multicolumn{3}{|c|}{ WATER }} \\
\hline $09-20-72$ & 5.95 & - & & & \\
\hline 12-19-72 & 6.79 & - & DATE & LEVEL & MS \\
\hline $03-29-73$ & 7.21 & $\mathbf{S}$ & DAIL & LEVEL & $\frac{1 \text { Nis }}{S}$ \\
\hline $06-21-73$ & 5.28 & $\mathrm{~s}$ & $09-21-95$ & 13.27 & $\mathbf{S}$ \\
\hline $09-18-73$ & 6.66 & S & $11-18-95$ & 13.90 & $\mathbf{S}$ \\
\hline $12-03-73$ & 6.60 & $\mathrm{~s}$ & $02-23-96$ & 13.50 & $\mathrm{~S}$ \\
\hline (2) & $\begin{array}{l}0.00 \\
6.30\end{array}$ & $\begin{array}{l}3 \\
\mathbf{S}\end{array}$ & $05-16-96$ & 14.96 & $\mathbf{S}$ \\
\hline
\end{tabular}

$06-27-74$

10-10-74

01-14-75

04-15-75

06-30-75

08-26-75

11-24-75

$02-10-76$

05-26-76

08-29-76

11-20-76

02-14-77

06-20-77

$09-21-77$

12-20-77

02-15-78

$05-10-78$

08-23-78

11-29-78

02-21-79

05-21-79

09-19-79

03-11-80

06-10-80

10-08-80

01-14-81

04-07-81

07-14-81

05-18-82

08-24-82
10N20W13BBA 01 cont.

MS

05-16-96

\section{N19W05CCCD01}

WATER

DATE

09-21-95

11-18-95

02-23-96

05-16-96

\begin{tabular}{r} 
LEVEL \\
\hline 3.26 \\
3.04 \\
3.44 \\
4.85
\end{tabular}

10N19W05CDCC01

\begin{tabular}{|c|c|c|}
\hline \multicolumn{3}{|c|}{ WATER } \\
\hline DATE & LEVEL & $\underline{\text { MS }}$ \\
\hline $10-30-94$ & 15.44 & $\mathrm{~S}$ \\
\hline $01-19-95$ & 15.19 & $\mathbf{S}$ \\
\hline $04-03-95$ & 18.03 & $\mathbf{S}$ \\
\hline $06-05-95$ & 11.59 & $\mathbf{S}$ \\
\hline $08-18-95$ & 11.77 & $\mathrm{~S}$ \\
\hline $09-22-95$ & 13.89 & SR \\
\hline $11-18-95$ & 13.54 & $\mathrm{~S}$ \\
\hline $02-23-96$ & 15.34 & $\mathbf{S}$ \\
\hline $05-15-96$ & 16.40 & $\mathbf{S}$ \\
\hline \multicolumn{3}{|c|}{ 10N19W05DCDD01 } \\
\hline & WATER & \\
\hline DATE & LEVEL & $\underline{\text { MS }}$ \\
\hline $10-30-94$ & 11.47 & \\
\hline
\end{tabular}

10N19W05DCDD01 cont.

$\begin{array}{ccc} & \text { WATER } & \\ \text { DATE } & \text { LEVEL } & \text { MS } \\ 01-19-95 & 12.53 & \mathbf{S} \\ 03-26-95 & 13.58 & \mathbf{S} \\ 06-04-95 & 14.20 & \mathbf{S} \\ 08-18-95 & 11.68 & \mathbf{S} \\ 09-12-95 & 10.57 & \mathbf{S} \\ 11-17-95 & 10.63 & \mathbf{S} \\ 02-23-96 & 11.79 & \mathbf{S} \\ 05-16-96 & 11.01 & \mathbf{S}\end{array}$

\section{N19W06CDCB01}

$\begin{array}{ccc} & \text { WATER } & \\ \text { DATE } & \text { LEVEL } & \text { MS } \\ 10-30-94 & 47.82 & \text { S } \\ 01-18-95 & 47.58 & \text { S } \\ 03-31-95 & 47.76 & \text { S } \\ 06-03-95 & 48.12 & \text { S } \\ 08-17-95 & 48.40 & \text { S } \\ 09-18-95 & 48.18 & \text { S } \\ 11-17-95 & 47.61 & \text { S } \\ 02-23-96 & 46.18 & \text { S }\end{array}$

10N19W06CDDA01

$\begin{array}{ccc} & \text { WATER } & \\ \text { DATE } & \text { LEVEL } & \text { MS } \\ 09-18-95 & 61.54 & \text { S } \\ 11-18-95 & 60.73 & \text { S } \\ 02-23-96 & 59.40 & \text { S } \\ 05-15-96 & 58.93 & \text { S }\end{array}$

\section{N19W06CDDD01*}

$\begin{array}{ccc}\text { DATE } & \begin{array}{c}\text { WATER } \\ \text { LEVEL }\end{array} & \text { MS } \\ 08-09-94 & 65.66 & \text { S } \\ 10-30-94 & 65.23 & \text { S } \\ 01-19-95 & 64.69 & \text { S } \\ 04-03-95 & 64.80 & \text { S } \\ 06-05-95 & 65.40 & \text { S } \\ 08-17-95 & 65.93 & \text { S } \\ 09-18-95 & 65.21 & \text { S } \\ 11-17-95 & 64.09 & \text { S } \\ 02-23-96 & 62.84 & \text { S } \\ 05-15-96 & 62.27 & \text { S } \\ 07-24-96 & 63.58 & \text { TR } \\ 09-24-96 & 61.26 & \text { T } \\ 11-19-96 & 59.86 & \text { S } \\ 01-07-97 & 59.34 & \text { S } \\ 02-26-97 & 58.70 & \text { S } \\ 04-03-97 & 58.25 & \text { S } \\ 05-21-97 & 57.71 & \text { S } \\ 06-24-97 & 52.62 & \text { S } \\ 08-19-97 & 48.89 & \text { S } \\ 10-15-97 & 46.90 & \text { S }\end{array}$

\section{N19W06DCCC01}

$\begin{array}{rcc} & \text { WATER } & \\ \text { DATE } & \text { LEVEL } & \text { MS } \\ 10-30-94 & 60.52 & \text { S } \\ 04-03-95 & 60.01 & \text { S } \\ 06-05-95 & 60.72 & \text { S } \\ 08-17-95 & 61.05 & \text { S } \\ 09-20-95 & 59.95 & \text { S } \\ 11-18-95 & 58.58 & \text { S } \\ 02-23-96 & 57.44 & \text { S } \\ 05-15-96 & 57.35 & \text { S }\end{array}$


Table 5. Records of water levels in wells (Continued)

10N19W06DCDA01

$\begin{array}{ccl}\text { DATE } & \begin{array}{c}\text { WATER } \\ \text { LEVEL }\end{array} & \text { MS } \\ 10-27-94 & 16.52 & \mathrm{~S} \\ 01-19-95 & 17.27 & \mathrm{~S} \\ 03-31-95 & 17.58 & \mathrm{~S} \\ 06-05-95 & 18.09 & \mathrm{~S} \\ 08-18-95 & 13.41 & \mathrm{~S} \\ 09-12-95 & 14.00 & \mathrm{~S} \\ 11-19-95 & 15.48 & \mathrm{~S} \\ 02-23-96 & 15.52 & \mathrm{SR} \\ 05-15-96 & 16.36 & \mathrm{~S}\end{array}$

\section{N19W06DDCCOI*}

$\begin{array}{ccc}\text { DATE } & \begin{array}{c}\text { WATER } \\ \text { LEVEL }\end{array} & \text { MS } \\ 08-10-94 & 111.87 & \mathrm{~S} \\ 10-31-94 & 111.44 & \mathrm{~S} \\ 01-19-95 & 111.88 & \mathrm{~S} \\ 03-31-95 & 111.52 & \mathrm{~S} \\ 06-05-95 & 111.94 & \mathrm{~S} \\ 08-17-95 & 112.50 & \mathrm{~S} \\ 09-20-95 & 112.32 & \mathrm{~S} \\ 11-18-95 & 111.48 & \mathrm{~S} \\ 02-23-96 & 110.40 & \mathrm{~S} \\ 05-15-96 & 109.97 & \mathrm{~S} \\ 07-24-96 & 110.47 & \mathrm{TR} \\ 09-24-96 & 109.59 & \mathrm{~T} \\ 11-19-96 & 112.31 & \mathrm{~S} \\ 01-07-97 & 108.09 & \mathrm{~S} \\ 02-26-97 & 106.86 & \mathrm{~S} \\ 04-03-97 & 106.65 & \mathrm{~S} \\ 05-20-97 & 106.44 & \mathrm{~S} \\ 06-24-97 & 106.22 & \mathrm{~S} \\ 08-19-97 & 105.05 & \mathrm{~S} \\ 10-15-97 & 104.92 & \mathrm{~S}\end{array}$

\section{N19W07ADBC01}

$\begin{array}{ccc} & \text { WATER } & \\ \text { DATE } & \text { LEVEL } & \text { MS } \\ 10-30-94 & 95.47 & \mathrm{~S} \\ 01-19-95 & 95.82 & \mathrm{~S} \\ 04-05-95 & 96.37 & \mathrm{~S} \\ 06-06-95 & 96.94 & \mathrm{~S} \\ 08-17-95 & 96.95 & \mathrm{~S} \\ 09-13-95 & 95.39 & \mathrm{~S} \\ 11-19-95 & 92.72 & \mathrm{~S} \\ 02-24-96 & 92.45 & \text { SR } \\ 05-16-96 & 92.70 & \text { SR }\end{array}$

\section{N19W07BAAD01*}

\begin{tabular}{ccc} 
DATE & $\begin{array}{c}\text { WATER } \\
\text { LEVEL }\end{array}$ & $\underline{\text { MS }}$ \\
\hline $09-08-94$ & 63.60 & $\mathrm{~S}$ \\
$10-20-94$ & 63.40 & $\mathrm{~S}$ \\
$01-19-95$ & 62.94 & $\mathrm{~S}$ \\
$03-26-95$ & 63.07 & $\mathrm{~S}$ \\
$06-05-95$ & 63.58 & $\mathrm{~S}$ \\
$08-17-95$ & 64.09 & $\mathrm{~S}$ \\
$09-18-95$ & 63.57 & $\mathrm{~S}$ \\
$11-17-95$ & 62.10 & $\mathrm{~S}$ \\
$02-23-96$ & 60.83 & $\mathrm{~S}$ \\
$05-15-96$ & 60.07 & $\mathrm{~S}$ \\
$07-24-96$ & 62.35 & $\mathrm{TR}$ \\
$09-24-96$ & 59.07 & $\mathrm{~T}$ \\
$11-19-96$ & 58.18 & $\mathrm{~S}$ \\
$01-07-97$ & 56.94 & $\mathrm{~S}$ \\
$02-26-97$ & 56.27 & $\mathrm{~S}$ \\
$04-03-97$ & 58.83 & $\mathrm{~S}$ \\
$05-20-97$ & 54.97 & $\mathrm{~S}$ \\
$06-24-97$ & 53.27 & $\mathrm{~S}$
\end{tabular}

10N19W07BACB01

$\begin{array}{ccl} & \text { WATER } & \\ \text { DATE } & \text { LEVEL } & \text { MS } \\ & 47.97 & \mathrm{~S} \\ 10-15-97 & 45.52 & \mathrm{~S} \\ 10-30-94 & 62.15 & \mathrm{~S} \\ 01-18-95 & 61.88 & \mathrm{~S} \\ 03-31-95 & 61.79 & \mathrm{SR} \\ 06-03-95 & 64.72 & \mathrm{~S} \\ 08-19-95 & 62.88 & \mathrm{~S} \\ 09-12-95 & 63.45 & \mathrm{~S} \\ 11-17-95 & 61.67 & \mathrm{~S}\end{array}$

\section{N19W07BDAD01}

$\begin{array}{ccc} & \text { WATER } & \\ \text { DATE } & \frac{\text { LEVEL }}{10-27-94} & \underline{\text { MS }} \\ 01-19-95 & 65.95 & \text { S } \\ 06-05-95 & 65.67 & \text { S } \\ 08-19-95 & 66.39 & \text { S } \\ 09-22-95 & 66.66 & \text { S } \\ 11-17-95 & 65.85 & \text { S } \\ 02-23-96 & 64.34 & \text { S } \\ 05-15-96 & 62.95 & \text { S } \\ & 62.08 & \text { S }\end{array}$

\section{N19W07BDBB01}

WATER

$\begin{array}{cc}\text { DATE } & \text { LEVEL } \\ 10-25-94 & 48.74 \\ 01-18-95 & 48.50 \\ 04-03-95 & 48.60 \\ 06-05-95 & 49.08 \\ 08-18-95 & 49.42 \\ 09-22-95 & 48.98 \\ 11-17-95 & 48.03 \\ 02-24-96 & 47.83 \\ 05-15-96 & 46.08\end{array}$

MS
$\mathbf{S}$
$\mathbf{S}$
$\mathbf{S}$
$\mathbf{S}$
$\mathbf{S}$
$\mathbf{S}$
$\mathbf{S}$
$\mathbf{S}$
$\mathbf{S}$

\section{N19W07CAAB01}

$\begin{array}{ccc} & \text { WATER } & \\ \text { DATE } & \text { LEVEL } & \text { M } \\ 10-25-94 & 33.89 & \mathrm{~S} \\ 01-18-95 & 34.17 & \mathrm{~S} \\ 04-05-95 & 34.57 & \mathrm{~S} \\ 06-03-95 & 35.29 & \mathrm{~S} \\ 08-18-95 & 34.74 & \mathrm{~S} \\ 09-15-95 & 34.53 & \mathrm{~S} \\ 11-18-95 & 33.22 & \mathrm{~S} \\ 02-24-96 & 30.82 & \mathrm{~S} \\ 05-16-96 & 29.76 & \mathrm{~S}\end{array}$

\section{N19W07CABD01*}

$\begin{array}{ccl}\text { DATE } & \begin{array}{c}\text { WATER } \\ \text { LEVEL }\end{array} & \text { MS } \\ 08-16-94 & 24.38 & \mathrm{~S} \\ 10-25-94 & 22.67 & \mathrm{~S} \\ 01-18-95 & 22.85 & \mathrm{~S} \\ 06-03-95 & 24.00 & \mathrm{~S} \\ 08-18-95 & 22.95 & \mathrm{~S} \\ 11-19-95 & 22.04 & \mathrm{SR} \\ 02-24-96 & 18.30 & \mathrm{~S} \\ 05-16-96 & 18.31 & \mathrm{~S} \\ 07-24-96 & 22.52 & \mathrm{~T} \\ 09-24-96 & 19.15 & \mathrm{~T} \\ 11-19-96 & 19.27 & \mathrm{~S} \\ 01-07-97 & 18.23 & \mathrm{~S} \\ 02-26-97 & 16.78 & \mathrm{~S} \\ 04-03-97 & 15.84 & \mathrm{~S} \\ 05-20-97 & 18.45 & \mathrm{~S}\end{array}$

10N19W07CABD01* cont.

\begin{tabular}{|c|c|c|}
\hline \multicolumn{3}{|c|}{ WATER } \\
\hline DATE & LEVEL & $\underline{\mathrm{M}}$ \\
\hline $06-24-97$ & 16.42 & S \\
\hline $08-19-97$ & 18.69 & \\
\hline $10-15-97$ & 15.72 & $\mathbf{S}$ \\
\hline \multicolumn{3}{|c|}{ 10N19W07CACC01 } \\
\hline & WATER & \\
\hline DATE & LEVEL & \\
\hline $10-30-94$ & 47.00 & $\mathbf{s}$ \\
\hline $01-18-95$ & 48.04 & $\mathbf{S}$ \\
\hline $03-31-95$ & 47.01 & \\
\hline $06-03-95$ & 47.34 & $\mathbf{S}$ \\
\hline $08-19-95$ & 47.46 & $\mathbf{S}$ \\
\hline $09-22-95$ & 46.74 & \\
\hline $11-18-95$ & 46.07 & \\
\hline $02-26-96$ & 44.37 & \\
\hline $05-15-96$ & 43.53 & \\
\hline
\end{tabular}

10N19W07CDAA01

$\begin{array}{rcl} & \text { WATER } & \\ \text { DATE } & \text { LEVEL } & \text { MS } \\ 10-31-94 & 24.53 & \text { S } \\ 01-19-95 & 24.98 & \text { S } \\ 04-05-95 & 25.49 & \text { S } \\ 06-03-95 & 25.12 & \text { S } \\ 08-18-95 & 24.54 & \text { S } \\ 09-22-95 & 23.91 & \text { S } \\ 11-18-95 & 23.56 & \text { S } \\ 02-25-96 & 20.04 & \text { S } \\ 05-15-96 & 20.23 & \text { SR }\end{array}$

10N19W07CDBA01

\begin{tabular}{ccl} 
DATE & $\begin{array}{c}\text { WATER } \\
\text { LEVEL }\end{array}$ & $\underline{\text { MS }}$ \\
\hline $10-27-94$ & 21.53 & S \\
$01-19-95$ & 21.66 & S \\
$04-05-95$ & 22.12 & S \\
$06-03-95$ & 22.93 & SR \\
$08-18-95$ & 21.81 & S \\
$09-22-95$ & 21.12 & SR \\
$11-17-95$ & 20.32 & S \\
$02-25-96$ & 16.59 & S \\
$05-15-96$ & 16.34 & S
\end{tabular}

\section{N19W07CDCC01*}

$\begin{array}{ccc} & \text { WATER } & \\ \text { DATE } & \text { LEVEL } & \text { MS } \\ 09-28-94 & 37.80 & \text { SR } \\ 01-21-95 & 34.01 & \text { S } \\ 03-31-95 & 33.53 & \text { S } \\ 06-03-95 & 36.63 & \text { S } \\ 08-18-95 & 32.18 & \text { S } \\ 09-13-95 & 33.43 & \text { T } \\ 11-17-95 & 31.72 & \text { S } \\ 02-25-96 & 30.07 & \text { S } \\ 05-16-96 & 29.22 & \text { S } \\ 07-24-96 & 39.35 & \text { TR } \\ 09-24-96 & 29.52 & \text { T } \\ 11-19-96 & 28.84 & \text { S } \\ 01-07-97 & 28.37 & \text { S } \\ 02-26-97 & 29.44 & \text { S } \\ 04-03-97 & 29.43 & \text { S } \\ 05-20-97 & & \text { P- } \\ 06-24-97 & 27.01 & \text { S } \\ 08-19-97 & 32.25 & \text { S } \\ 10-15-97 & 25.04 & \text { S }\end{array}$


Table 5. Records of water levels in wells (Continued)

\begin{tabular}{|c|c|c|}
\hline & WATER & \\
\hline DATE & LEVEL & $\underline{\mathrm{MS}}$ \\
\hline $08-17-95$ & 64.38 & S \\
\hline $09-21-95$ & 63.33 & S \\
\hline $11-18-95$ & 63.93 & $\mathbf{S}$ \\
\hline $05-16-96$ & 59.70 & $\mathrm{~s}$ \\
\hline $07-24-96$ & 58.18 & $\mathrm{TR}$ \\
\hline $09-24-96$ & 56.46 & $\mathrm{~T}$ \\
\hline $11-19-96$ & 58.07 & S \\
\hline $01-07-97$ & 55.35 & $S$ \\
\hline $02-26-97$ & 55.85 & $\mathrm{~S}$ \\
\hline $04-03-97$ & 54.57 & $s$ \\
\hline $05-20-97$ & 53.93 & S \\
\hline $06-24-97$ & 49.47 & \\
\hline $08-19-97$ & & \\
\hline $10-15-97$ & 41.70 & $\mathrm{~s}$ \\
\hline
\end{tabular}

\begin{tabular}{ccc}
\multicolumn{2}{c}{ 10N19W07DBDA01 } & \\
& WATER & \\
DATE & LEVEL & MS \\
$09-21-95$ & 37.67 & S \\
$11-19-95$ & 37.38 & S \\
$02-24-96$ & 35.59 & S \\
$05-16-96$ & 31.48 & S
\end{tabular}

\begin{tabular}{ccc}
\multicolumn{2}{c}{ 10N19W07DDCD01 } \\
DATE & WATER & \\
LEVEL & & MS \\
$11-02-94$ & 35.25 & S \\
$01-18-95$ & 38.63 & S \\
$06-06-95$ & 36.15 & S \\
$08-18-95$ & 33.76 & S \\
$09-20-95$ & 33.04 & S \\
$11-17-95$ & 33.33 & S \\
$02-24-96$ & 29.50 & SR \\
$05-16-96$ & 26.47 & S
\end{tabular}

\begin{tabular}{ccc}
\multicolumn{2}{c}{ 10N19W07DDDC01 } \\
DATE & WATER & \\
LATVE & MS \\
$11-02-94$ & 42.12 & S \\
$01-18-95$ & 44.36 & S \\
$04-05-95$ & 43.64 & S \\
$06-06-95$ & 41.29 & S \\
$08-19-95$ & 39.39 & S \\
$09-18-95$ & 38.86 & S \\
$11-17-95$ & 38.99 & S \\
$02-24-96$ & 35.19 & S \\
$05-16-96$ & 32.17 & S
\end{tabular}

\begin{tabular}{ccc}
\multicolumn{2}{c}{ 10N19W08ABBC01* } \\
\cline { 2 - 3 } DATE & WATER & \\
DE-03-94 & LEVEL & MS \\
$10-31-94$ & 30.60 & S \\
$01-18-95$ & 36.52 & S \\
$04-05-95$ & 33.17 & S \\
$06-03-95$ & 37.34 & S \\
$08-18-95$ & 28.66 & S \\
$09-20-95$ & 28.72 & S \\
$11-18-95$ & 31.24 & S \\
$02-24-96$ & 31.84 & S \\
$05-15-96$ & 35.80 & S \\
$07-24-96$ & 26.40 & S \\
$09-24-96$ & 26.53 & T \\
$11-19-96$ & 29.41 & S \\
$01-07-97$ & 35.55 & SR \\
$02-26-97$ & 31.67 & S
\end{tabular}

10N19W08ABBC01* cont.

$\begin{array}{ccc} & \text { WATER } & \\ \underline{\text { DATE }} & \text { LEVEL } & \underline{\text { MS }} \\ 04-03-97 & 28.18 & \text { S } \\ 05-20-97 & 21.19 & \text { S } \\ 06-24-97 & 21.12 & \text { S } \\ 08-19-97 & 22.56 & \text { S } \\ 10-15-97 & 28.48 & \text { S }\end{array}$

10N19W08ADAD01

$\begin{array}{crl} & \text { WATER } & \\ \text { DATE } & \text { LEVEL } & \text { MS } \\ 10-25-94 & 103.56 & \mathrm{~S} \\ 01-14-95 & 89.95 & \mathrm{~S} \\ 03-26-95 & 86.92 & \mathrm{~S} \\ 06-03-95 & 102.81 & \mathrm{~S} \\ 08-15-95 & 108.19 & \mathrm{SR} \\ 09-20-95 & 100.82 & \mathrm{~S} \\ 11-18-95 & 91.93 & \mathrm{~S} \\ 02-23-96 & 93.78 & \mathrm{SR} \\ 05-15-96 & 86.11 & \text { SR }\end{array}$

10N19W08ADDC01

$\begin{array}{ccl} & \text { WATER } & \\ \text { DATE } & \underline{\text { LEVEL }} & \underline{\text { MS }} \\ 10-25-94 & 117.44 & \mathrm{SR} \\ 01-18-95 & 100.63 & \mathrm{~S} \\ 04-03-95 & 92.15 & \mathrm{~S} \\ 06-03-95 & 115.97 & \mathrm{SR} \\ 08-15-95 & 113.36 & \mathrm{~S} \\ 09-12-95 & 110.65 & \mathrm{~T} \\ 11-18-95 & 100.52 & \mathrm{~S} \\ 02-26-96 & 101.14 & \mathrm{SR} \\ 05-17-96 & 98.31 & \text { SR }\end{array}$

\section{N19W08BADD01}

WATER

$\begin{array}{ccc}\text { DATE } & \text { LEVEL } & \text { MS } \\ 10-31-94 & 237.01 & \text { S } \\ 01-16-95 & 237.26 & \text { S } \\ 03-27-95 & 237.13 & \text { S } \\ 06-04-95 & 237.21 & \text { S } \\ 08-15-95 & 238.92 & \text { S } \\ 09-22-95 & 237.26 & \text { S } \\ 11-17-95 & 236.79 & \text { S } \\ 02-23-96 & 235.95 & \text { S } \\ 05-15-96 & 235.75 & \text { S }\end{array}$

\section{N19W08BBDD01}

$\begin{array}{ccc} & \text { WATER } & \\ \text { DATE } & \underline{\text { LEVEL }} & \underline{\mathrm{MS}} \\ 01-18-95 & 203.48 & \mathrm{~S} \\ 06-05-95 & 203.70 & \mathrm{~S} \\ 08-15-95 & 205.41 & \mathrm{~S} \\ 09-20-95 & 204.02 & \mathrm{~S} \\ 05-17-96 & 202.51 & \mathrm{~S}\end{array}$

\begin{tabular}{ccc}
\multicolumn{2}{c}{ 10N19W08BCADO1* } \\
DATE & WATER & \\
$08-15-94$ & LEVEL & MS \\
$10-31-94$ & 197.42 & S \\
$01-18-95$ & 196.78 & S \\
$04-05-95$ & 196.85 & S \\
$06-06-95$ & 196.68 & S \\
$08-15-95$ & 200.40 & S \\
$09-13-95$ & 198.07 & T \\
$11-18-95$ & 196.85 & S
\end{tabular}

10N19W08BCAD01* cont.

$\begin{array}{ccc} & \text { WATER } & \\ \text { DATE } & \text { LEVEL } & \text { MS } \\ 02-26-96 & 196.57 & \text { S } \\ 05-15-96 & 195.98 & \text { SR } \\ 07-25-96 & 204.27 & \text { TR } \\ 09-24-96 & 197.74 & \text { T } \\ 11-19-96 & 198.02 & \text { S } \\ 01-07-97 & 199.83 & \text { S } \\ 02-26-97 & 199.90 & \text { S } \\ 04-03-97 & 195.68 & \text { S } \\ 05-20-97 & & \text { P- } \\ 06-24-97 & 204.99 & \text { S } \\ 08-19-97 & 204.99 & \text { S } \\ 10-15-97 & 201.16 & \text { S }\end{array}$

10N19W08BCBB01

$\begin{array}{ccc} & \text { WATER } & \\ \underline{\text { DATE }} & \underline{\text { LEVEL }} & \underline{\mathrm{MS}} \\ 010-27-94 & 145.18 & \mathrm{~S} \\ 01-16-95 & 144.38 & \mathrm{~S} \\ 03-26-95 & 144.93 & \mathrm{~S} \\ 06-05-95 & 144.40 & \mathrm{~S} \\ 08-16-95 & 145.75 & \mathrm{~S} \\ 09-22-95 & 145.57 & \mathrm{~S} \\ 11-18-95 & 144.77 & \mathrm{~S} \\ 02-24-96 & 147.08 & \mathrm{~S} \\ 05-15-96 & 142.82 & \mathrm{~S}\end{array}$

\section{N19W08BCCC01}

$\begin{array}{ccc} & \text { WATER } & \\ \text { DATE } & \underline{\text { LEVEL }} & \underline{\mathrm{MS}} \\ 10-31-94 & 129.60 & \mathrm{~S} \\ 01-19-95 & 130.22 & \mathrm{~S} \\ 03-31-95 & 130.10 & \mathrm{~S} \\ 06-05-95 & 130.40 & \mathrm{~S} \\ 08-17-95 & 130.45 & \mathrm{~S} \\ 09-20-95 & 130.35 & \mathrm{~S} \\ 11-19-95 & 128.79 & \mathrm{~S} \\ 02-23-96 & 126.82 & \mathrm{~S} \\ 05-15-96 & 125.98 & \mathrm{~S}\end{array}$

\section{N19W08BDAB01}

\begin{tabular}{|c|c|c|}
\hline DATE & $\begin{array}{l}\text { WATER } \\
\text { LEVEL }\end{array}$ & $\underline{\mathrm{MS}}$ \\
\hline $10-30-94$ & 228.10 & SR \\
\hline $01-16-95$ & 227.77 & $\mathrm{~S}$ \\
\hline $03-27-95$ & 227.29 & $\mathbf{S}$ \\
\hline $06-05-95$ & 227.26 & S \\
\hline $08-15-95$ & 229.19 & $\mathbf{S}$ \\
\hline $09-22-95$ & 227.42 & S \\
\hline $11-17-95$ & 227.08 & S \\
\hline $02-24-96$ & 227.32 & SR \\
\hline $05-17-96$ & 226.32 & $\mathbf{S}$ \\
\hline
\end{tabular}

\section{N19W08CBDD01*}

\begin{tabular}{|c|c|c|}
\hline DATE & $\begin{array}{l}\text { WATER } \\
\text { LEVEL }\end{array}$ & $\underline{\text { MS }}$ \\
\hline $08-23-94$ & 51.75 & $\mathbf{S}$ \\
\hline $10-31-94$ & 56.08 & $\mathbf{S}$ \\
\hline $01-18-95$ & 57.68 & $\mathbf{S}$ \\
\hline $03-27-95$ & 55.83 & $\mathbf{S}$ \\
\hline $06-06-95$ & 52.30 & $\mathbf{S}$ \\
\hline $08-16-95$ & 49.79 & $\mathbf{S}$ \\
\hline $09-22-95$ & 49.48 & $\mathbf{S}$ \\
\hline $11-17-95$ & 51.01 & $\mathbf{S}$ \\
\hline $02-25-96$ & 47.73 & $\mathbf{S}$ \\
\hline $05-16-96$ & 45.67 & $\mathbf{S}$ \\
\hline $07-25-96$ & 43.72 & $T$ \\
\hline
\end{tabular}


Table 5. Records of water levels in wells (Continued)

10N19W08CBDD01* cont.

$\begin{array}{ccc}\text { WATER } & \\ \text { DATE } & \text { LEVEL } & \text { MS } \\ 09-24-96 & 43.95 & \mathrm{~T} \\ 11-19-96 & 46.88 & \mathrm{~S} \\ 01-07-97 & 44.54 & \mathrm{~S} \\ 02-26-97 & 43.53 & \mathrm{~S} \\ 04-03-97 & 43.47 & \mathrm{~S} \\ 05-20-97 & 42.52 & \mathrm{~S} \\ 06-24-97 & 35.81 & \mathrm{~S} \\ 08-19-97 & 32.00 & \mathrm{~S} \\ 10-15-97 & 34.95 & \mathrm{~S}\end{array}$

\section{N19W08CDAC01}

$\begin{array}{ccc} & \text { WATER } & \\ \text { DATE } & \text { LEVEL } & \text { MS } \\ 10-31-94 & 77.50 & \text { S } \\ 01-19-95 & 79.02 & \text { S } \\ 03-27-95 & 78.91 & \text { S } \\ 06-06-95 & 77.99 & \text { S } \\ 08-16-95 & 72.99 & \text { S } \\ 09-13-95 & 73.48 & \text { S } \\ 11-17-95 & 74.39 & \text { S } \\ 02-25-96 & 72.48 & \text { S } \\ 05-17-96 & 71.48 & \text { S }\end{array}$

\section{N19W08DAAC01}

\begin{tabular}{|c|c|c|}
\hline & WATER & \\
\hline DATE & LEVEL & $\underline{\text { MS }}$ \\
\hline $11-02-94$ & 71.58 & $\mathbf{S}$ \\
\hline $01-18-95$ & 68.05 & $\mathbf{S}$ \\
\hline $03-27-95$ & 66.96 & $\mathbf{S}$ \\
\hline $06-04-95$ & 77.19 & $\mathbf{S}$ \\
\hline $08-17-95$ & 73.15 & \\
\hline $09-22-95$ & 73.04 & $\mathrm{~s}$ \\
\hline $11-17-95$ & 68.53 & \\
\hline $02-25-96$ & 65.83 & \\
\hline $05-16-96$ & 65.46 & \\
\hline
\end{tabular}

\section{N19W08DBBD01}

$\begin{array}{ccc} & \text { WATER } & \\ \text { DATE } & \text { LEVEL } & \text { MS } \\ 08-15-95 & 199.75 & \text { S } \\ 11-17-95 & 198.23 & \text { S } \\ 02-26-96 & 198.77 & \text { S } \\ 05-17-96 & 196.68 & \text { S }\end{array}$

\section{N19W08DCCB01*}

$\begin{array}{ccc} & \text { WATER } & \\ \text { DATE } & \text { LEVEL } & \text { MS } \\ 08-19-95 & 115.90 & \mathrm{~S} \\ 11-17-95 & 115.69 & \mathrm{~S} \\ 02-23-96 & 117.79 & \mathrm{~S} \\ 05-16-96 & 114.14 & \mathrm{~S} \\ 07-25-96 & 113.03 & \mathrm{~T} \\ 09-24-96 & 112.33 & \mathrm{~T} \\ 11-19-96 & 111.94 & \mathrm{~S} \\ 01-07-97 & 112.18 & \mathrm{~S} \\ 02-26-97 & 111.73 & \mathrm{~S} \\ 04-03-97 & 111.78 & \mathrm{~S} \\ 05-20-97 & 110.79 & \mathrm{~S} \\ 06-24-97 & 107.97 & \mathrm{~S} \\ 08-19-97 & 106.55 & \mathrm{~S} \\ 10-15-97 & 107.01 & \mathrm{~S}\end{array}$

10N19W08DCCC01

$\begin{array}{ccc} & \text { WATER } & \\ \text { DATE } & \text { LEVEL } & \text { MS } \\ 08-19-94 & 136.80 & - \\ 10-31-94 & 136.73 & \text { S } \\ 01-16-95 & 137.81 & \text { S }\end{array}$

10N19W08DCCC02

$\begin{array}{ccc} & \text { WATER } & \\ \text { DATE } & \text { LEVEL } & \text { MS } \\ 08-26-93 & 150.52 & \text { R } \\ 12-06-93 & 141.15 & \text { R } \\ 03-10-94 & 140.82 & \text { R } \\ 06-16-94 & 140.84 & \text { R } \\ 09-27-94 & 141.84 & \text { R } \\ 12-20-94 & 143.32 & \text { R } \\ 03-23-95 & 143.05 & \text { R } \\ 06-27-95 & 141.87 & \text { R } \\ 09-28-95 & 140.19 & \text { R } \\ 12-19-95 & 139.97 & \text { R } \\ 03-14-96 & 138.39 & \text { R } \\ 06-18-96 & 136.82 & \text { R } \\ 09-24-96 & 135.56 & \text { R } \\ 12-19-96 & 135.35 & \text { R } \\ 06-17-97 & 133.94 & \text { R } \\ 09-04-97 & 128.30 & \text { R }\end{array}$

10N19W09BCCCO1*

$\begin{array}{ccl} & \text { WATER } & \\ \text { DATE } & \text { LEVEL } & \text { MS } \\ 01-14-95 & 51.59 & \text { S } \\ 03-26-95 & 49.13 & \text { S } \\ 06-03-95 & 79.13 & \text { S } \\ 08-17-95 & 77.78 & \text { S } \\ 11-17-95 & 56.95 & \text { SR } \\ 02-24-96 & 48.87 & \text { S } \\ 05-16-96 & 47.25 & \text { S } \\ 07-24-96 & 57.21 & \text { TR } \\ 09-24-96 & 59.03 & \text { T } \\ 11-19-96 & 54.77 & \text { S } \\ 01-07-97 & 48.94 & \text { S } \\ 02-26-97 & 47.97 & \text { S } \\ 04-03-97 & 36.71 & \text { S } \\ 05-20-97 & 60.69 & \text { S } \\ 06-24-97 & 53.22 & \text { S } \\ 08-19-97 & 81.95 & \text { S } \\ 10-15-97 & 52.34 & \text { S }\end{array}$

\section{N19W16BBBC01}

$\begin{array}{ccl} & \text { WATER } & \\ \text { DATE } & \underline{\text { LEVEL }} & \text { MS } \\ 10-31-94 & 204.12 & \mathrm{~S} \\ 01-14-95 & 204.10 & \mathrm{~S} \\ 03-27-95 & 205.04 & \mathrm{~S} \\ 06-06-95 & 204.44 & \mathrm{~S} \\ 08-16-95 & 204.73 & \mathrm{~S} \\ 09-15-95 & 204.56 & \mathrm{SR} \\ 11-18-95 & 203.84 & \mathrm{~S} \\ 02-25-96 & 203.62 & \text { SR } \\ 05-16-96 & 201.76 & \mathrm{~S}\end{array}$

\begin{tabular}{ccc}
\multicolumn{2}{c}{ 10N19W17BAAA01 } & \\
DATE & WATER & \\
$10-31-94$ & $\frac{\text { LEVEL }}{121.44}$ & MS \\
$01-14-95$ & 122.96 & $\mathrm{~S}$ \\
$03-27-95$ & 123.18 & $\mathrm{~S}$ \\
$06-06-95$ & 121.20 & $\mathrm{~S}$ \\
$08-16-95$ & 119.81 & $\mathrm{~S}$
\end{tabular}

10N19W17BAAA01 cont.

$\begin{array}{ccc} & \text { WATER } & \\ \text { DATE } & \text { LEVEL } & \text { MS } \\ 09-21-95 & 119.64 & \mathrm{~S} \\ 11-17-95 & 119.35 & \mathrm{~S} \\ 02-23-96 & 117.03 & \mathrm{~S} \\ 05-18-96 & 115.44 & \mathrm{~S}\end{array}$

10N19W17BBDA01

\begin{tabular}{|c|c|c|}
\hline & WATER & \\
\hline DATE & LEVEL & $\underline{\mathrm{MS}}$ \\
\hline $11-02-94$ & 93.22 & $\mathbf{S}$ \\
\hline $01-16-95$ & 94.99 & S \\
\hline $03-27-95$ & 94.29 & $\mathbf{S}$ \\
\hline $06-06-95$ & 91.64 & S \\
\hline $08-16-95$ & 90.45 & S \\
\hline $09-18-95$ & 90.84 & SR \\
\hline $11-17-95$ & 90.62 & SR \\
\hline $02-25-96$ & 88.01 & SR \\
\hline $05-17-96$ & 84.89 & $\mathbf{S}$ \\
\hline
\end{tabular}

\section{N19W17BCAB01}

$\begin{array}{ccc} & \text { WATER } & \\ \text { DATE } & \frac{\text { LEVEL }}{90.49} & \underline{\text { MS }} \\ 11-02-94 & 91.71 & \text { S } \\ 01-16-95 & 89.54 & \text { S } \\ 03-27-95 & 89.54 & \text { S } \\ 06-06-95 & 88.37 & \text { S } \\ 08-17-95 & 88.40 & \text { S } \\ 09-18-95 & 84.35 & \text { SR } \\ 11-17-95 & & \end{array}$

\section{N19W17BCCCO1}

$\begin{array}{ccl} & \text { WATER } & \\ \text { DATE } & \text { LEVEL } & \text { MS } \\ 08-19-95 & 94.95 & \text { S } \\ 09-18-95 & 94.18 & \text { S } \\ 11-17-95 & 93.95 & \text { S } \\ 02-24-96 & 91.86 & \text { SR } \\ 05-17-96 & 88.74 & \text { S }\end{array}$

\section{N19W18AAAA01}

$\begin{array}{ccc} & \text { WATER } & \\ \text { DATE } & \text { LEVEL } & \text { MS } \\ 08-24-94 & 45.23 & \text { S } \\ 11-02-94 & 46.45 & \text { S } \\ 01-19-95 & 48.53 & \text { S } \\ 03-26-95 & 48.03 & \text { S } \\ 06-06-95 & 45.17 & \text { S }\end{array}$

\section{N19W18AADB01*}

$\begin{array}{ccl}\text { DATE } & \begin{array}{c}\text { WATER } \\ \text { LEVEL }\end{array} & \text { MS } \\ 08-16-95 & 42.98 & \text { SR } \\ 09-13-95 & 42.58 & \mathrm{~T} \\ 11-17-95 & 42.91 & \mathrm{~S} \\ 02-25-96 & 39.36 & \mathrm{~S} \\ 05-16-96 & 35.28 & \mathrm{~S} \\ 07-25-96 & 40.94 & \mathrm{TR} \\ 09-24-96 & 36.18 & \mathrm{~T} \\ 11-19-96 & 37.17 & \mathrm{~S} \\ 01-07-97 & 37.79 & \mathrm{~S} \\ 02-26-97 & 34.31 & \mathrm{~S} \\ 04-03-97 & 33.38 & \mathrm{~S} \\ 05-20-97 & 38.69 & \mathrm{~S} \\ 06-24-97 & 29.48 & \mathrm{~S} \\ 08-19-97 & 35.73 & \mathrm{~S} \\ 10-15-97 & 31.23 & \mathrm{~S}\end{array}$


Table 5. Records of water levels in wells (Continued)

10N19W18ABAD01

$\begin{array}{ccc} & \text { WATER } & \\ \text { DATE } & \text { LEVEL } & \text { MS } \\ 08-16-95 & 30.30 & \text { S } \\ 09-18-95 & 29.68 & \text { S } \\ 11-17-95 & 30.28 & \text { S } \\ 02-23-96 & 26.09 & \text { S } \\ 05-16-96 & 22.67 & \text { S }\end{array}$

\section{N19W18ADDC01*}

$\begin{array}{ccl}\text { DATE } & \begin{array}{c}\text { WATER } \\ \text { LEVEL }\end{array} & \text { MS } \\ 01-21-95 & 85.66 & \mathrm{~S} \\ 06-06-95 & 87.59 & \mathrm{~S} \\ 08-22-95 & 81.84 & \mathrm{~S} \\ 09-18-95 & 81.37 & \mathrm{~S} \\ 11-17-95 & 81.93 & \mathrm{~S} \\ 02-26-96 & 78.86 & \mathrm{SR} \\ 05-17-96 & 75.65 & \mathrm{~S} \\ 07-25-96 & 76.27 & \mathrm{~T} \\ 09-24-96 & 76.86 & \mathrm{~T} \\ 11-19-96 & 79.47 & \mathrm{~S} \\ 01-07-97 & 78.86 & \mathrm{~S} \\ 02-26-97 & 75.65 & \mathrm{~S} \\ 04-03-97 & 74.33 & \mathrm{~S} \\ 05-20-97 & 73.85 & \mathrm{~S} \\ 06-24-97 & 70.58 & \mathrm{~S} \\ 08-19-97 & 71.38 & \mathrm{~S} \\ 10-15-97 & 74.32 & \mathrm{~S}\end{array}$

\section{N19W18DBBA01}

$\begin{array}{ccc}\text { DATE } & \begin{array}{c}\text { WATER } \\ \text { LEVEL }\end{array} & \underline{\text { MS }} \\ 01-21-95 & 71.09 & \text { S } \\ 06-08-95 & 70.74 & \text { S } \\ 08-22-95 & 67.77 & \text { S } \\ 09-13-95 & 67.45 & \text { T } \\ 11-19-95 & 68.82 & \text { S } \\ 02-26-96 & 67.36 & \text { S } \\ 05-17-96 & 64.40 & \text { S }\end{array}$

\section{N20W20ACAD01}

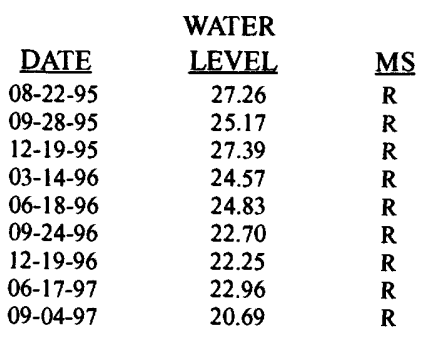

\section{N20W26BACC02}

\begin{tabular}{|c|c|c|}
\hline DATE & $\begin{array}{l}\text { WATER } \\
\text { LEVEL }\end{array}$ & $\underline{\mathbf{M}}$ \\
\hline $08-26.93$ & 80.08 & $\mathbf{R}$ \\
\hline $12-07-93$ & 81.45 & $\mathbf{R}$ \\
\hline 03-09-94 & 60.76 & $\mathbf{R}$ \\
\hline $06-16-94$ & 79.65 & $\mathbf{R}$ \\
\hline $09-27-94$ & 80.80 & $R$ \\
\hline $12-20-94$ & 80.52 & $\mathbf{R}$ \\
\hline $03-23-95$ & 80.31 & $R$ \\
\hline $06-27-95$ & 79.02 & $R$ \\
\hline $09-28-95$ & 79.68 & $\mathbf{R}$ \\
\hline $12-19-95$ & 79.14 & $\mathbf{R}$ \\
\hline $03-14-96$ & 79.68 & $\mathbf{R}$ \\
\hline $06-03-96$ & 79.54 & $\mathrm{~T}$ \\
\hline
\end{tabular}

09N20W26BACC02 cont.

$\begin{array}{ccc}\text { DATE } & \begin{array}{c}\text { WATER } \\ \text { LEVEL }\end{array} & \text { MS } \\ 06-18-96 & \frac{78.80}{\mathrm{R}} & \mathrm{R} \\ 09-24-96 & 78.17 & \mathrm{R} \\ 12-19-96 & 79.91 & \mathrm{R} \\ 06-17-97 & 78.45 & \mathrm{R} \\ 09-04-97 & 79.70 & \mathrm{R}\end{array}$

\section{$\underline{08 \mathrm{~N} 21 \mathrm{~W} 27 \mathrm{DCBC} 01}$}

\begin{tabular}{|c|c|c|}
\hline DATE & $\begin{array}{l}\text { WATER } \\
\text { LEVEL }\end{array}$ & $\underline{\text { MS }}$ \\
\hline $08-26-93$ & 6.56 & $\mathbf{R}$ \\
\hline $12-07-93$ & 11.70 & $\mathbf{R}$ \\
\hline $03-13-94$ & 11.88 & $\mathbf{R}$ \\
\hline $06-16-94$ & 2.75 & $\mathbf{R}$ \\
\hline $09-27-94$ & 13.65 & $\mathbf{R}$ \\
\hline $12-20-94$ & 12.95 & $\mathbf{R}$ \\
\hline $03-23-95$ & 10.80 & $\mathbf{R}$ \\
\hline $06-27-95$ & 2.39 & $\mathbf{R}$ \\
\hline $09-28-95$ & 8.46 & $\mathbf{R}$ \\
\hline $12-19-95$ & 7.11 & $\mathbf{R}$ \\
\hline $03-14-96$ & 4.36 & $\mathbf{R}$ \\
\hline $06-03-96$ & 4.66 & $\mathrm{~T}$ \\
\hline $06-18-96$ & 2.47 & $\mathbf{R}$ \\
\hline $09-24-96$ & 8.08 & $\mathbf{R}$ \\
\hline $12-19-96$ & 11.53 & $\mathbf{R}$ \\
\hline $06-17-97$ & 1.78 & . \\
\hline $09-04-97$ & 8.62 & \\
\hline
\end{tabular}

\section{N20W12BAAA01*}

$\begin{array}{ccc} & \text { WATER } & \\ \text { DATE } & \text { LEVEL } & \text { MS } \\ 10-10-95 & 54.99 & \mathrm{~S} \\ 11-19-96 & 46.46 & \mathrm{~S} \\ 01-07-97 & 47.73 & \mathrm{~S} \\ 02-26.97 & 45.18 & \mathrm{~S} \\ 04-03-97 & 51.46 & \mathrm{~S} \\ 05-20-97 & 45.32 & \mathrm{~S} \\ 06-24-97 & 42.29 & \mathrm{~S} \\ 08-19-97 & 40.77 & \mathrm{~S} \\ 10-15-97 & 40.47 & \mathrm{~S}\end{array}$

\section{N20W19BAAD03}

$\begin{array}{ccc} & \text { WATER } & \\ \text { DATE } & \text { LEVEL } & \underline{\text { MS }} \\ 07-03-57 & 14.64 & -- \\ 08-13-57 & 14.98 & - \\ 09-05-57 & 15.50 & - \\ 11-06-57 & 15.64 & - \\ 12-06-57 & 16.04 & - \\ 01-20-58 & 16.32 & - \\ 02-11-58 & 16.54 & -- \\ 03-07-58 & 16.21 & - \\ 04-15-58 & 16.35 & - \\ 05-06-58 & 14.81 & - \\ 06-17-58 & 14.27 & - \\ 07-53-58 & 14.01 & - \\ 08-05-58 & 14.26 & -- \\ 09-03-58 & 14.68 & - \\ 00-02-58 & 14.53 & - \\ 01-03-58 & 15.13 & - \\ 02-09-58 & 15.11 & - \\ 01-02-59 & 15.30 & - \\ 02-06-59 & 16.22 & -- \\ 03-05-59 & 16.29 & - \\ 04-01-59 & 16.49 & - \\ 04-10-59 & 16.14 & - \\ 05-10-59 & 14.28 & - \\ 06-05-59 & 13.52 & - \\ 07-10-59 & 13.76 & --\end{array}$

08N20W19BAAD03 cont.

\begin{tabular}{|c|c|c|}
\hline & WATER & \\
\hline DATE & LEVEL & $\underline{\text { MS }}$ \\
\hline $08-05-59$ & 13.76 & - \\
\hline $09-16-59$ & 12.74 & -- \\
\hline $00-05-59$ & 13.65 & _ \\
\hline $01-20-59$ & 14.70 & - \\
\hline $02-10-59$ & 15.07 & - \\
\hline $01-10-60$ & 15.95 & - \\
\hline $02-10-60$ & 16.37 & -- \\
\hline $03-16-60$ & 17.03 & - \\
\hline $04-08-60$ & 16.58 & -- \\
\hline $05-24-60$ & 13.03 & - \\
\hline $06-06-60$ & 13.54 & - \\
\hline $07-07-60$ & 12.97 & - \\
\hline $08-02-60$ & 12.91 & -- \\
\hline $09-01-60$ & 13.61 & - \\
\hline $10-10-60$ & 14.13 & - \\
\hline $11-16-60$ & 14.16 & -- \\
\hline $12-18-60$ & 15.42 & - \\
\hline $01-02-61$ & 15.61 & - \\
\hline $02-06-61$ & 16.15 & - \\
\hline $03-03-61$ & 15.84 & -- \\
\hline $04-02-61$ & 16.28 & - \\
\hline $05-02-61$ & 13.93 & -- \\
\hline $06-06-61$ & 13.23 & -- \\
\hline $07-07-61$ & 12.69 & -- \\
\hline $08-13-61$ & 12.88 & -- \\
\hline $09-02-61$ & 12.39 & -- \\
\hline $10-09-61$ & 13.15 & -- \\
\hline $11-22-61$ & 14.68 & - \\
\hline $12-30-61$ & 15.06 & - \\
\hline $03-02-62$ & 16.86 & - \\
\hline $08-27-62$ & 14.12 & - \\
\hline $03-04-63$ & 15.60 & - \\
\hline $09-06-63$ & 13.92 & -- \\
\hline $03-13-64$ & 16.47 & -- \\
\hline $03-05-65$ & 16.20 & -- \\
\hline $09-03-65$ & 14.65 & -- \\
\hline $03-08-66$ & 18.03 & -- \\
\hline $09-07-66$ & 15.32 & -- \\
\hline $11-30-66$ & 15.90 & -- \\
\hline $03-06-67$ & 16.87 & - \\
\hline $06-05-67$ & 14.35 & - \\
\hline $09-11-67$ & 15.08 & -- \\
\hline $11-30-67$ & 15.70 & -- \\
\hline $03-07-68$ & 16.70 & -- \\
\hline $05-28-68$ & 14.56 & - \\
\hline $08-21-68$ & 14.48 & - \\
\hline $12-11-68$ & 16.36 & - \\
\hline $06-10-69$ & 14.48 & - \\
\hline $09-04-69$ & 15.58 & - \\
\hline $12-17-69$ & 17.21 & -- \\
\hline $03-11-70$ & 18.09 & - \\
\hline $06-24-70$ & 15.14 & -- \\
\hline $09-10-70$ & 14.71 & -- \\
\hline $11-12-70$ & 16.01 & - \\
\hline $02-17-71$ & 17.07 & -- \\
\hline $06-02-71$ & 14.52 & -- \\
\hline $09-13-71$ & 15.07 & -- \\
\hline $12-21-71$ & 16.52 & - \\
\hline $03-13-72$ & 16.67 & -- \\
\hline $06-26-72$ & 16.23 & -- \\
\hline $09-20-72$ & 16.34 & -- \\
\hline $03-29-73$ & 19.76 & 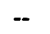 \\
\hline $06-21-73$ & 15.87 & -- \\
\hline $12-03-73$ & 17.71 & -- \\
\hline $03-19-74$ & 18.86 & - \\
\hline $06-27-74$ & 16.48 & -- \\
\hline $10-09-74$ & 16.87 & -- \\
\hline $01-14-75$ & 19.02 & - \\
\hline $04-15-75$ & 18.19 & -- \\
\hline $06-30-75$ & 16.14 & -- \\
\hline $08-26-75$ & 15.90 & -- \\
\hline $11-24-75$ & 17.86 & $\mathbf{S}$ \\
\hline $02-10-76$ & 19.22 & \\
\hline
\end{tabular}


Table 5. Records of water levels in wells (Continued)

08N20W19BAAD03 cont.

\begin{tabular}{|c|c|c|}
\hline DATE & $\begin{array}{l}\text { WATER } \\
\text { LEVEL }\end{array}$ & MS \\
\hline $05-26-76$ & 16.12 & - \\
\hline $08-29-76$ & 16.67 & $\ldots$ \\
\hline $11-10-76$ & 17.00 & - \\
\hline $02-14-77$ & 19.69 & - \\
\hline $06-20-77$ & 16.26 & -- \\
\hline $09-21-77$ & 16.58 & - \\
\hline $12-20-77$ & 17.19 & - \\
\hline $02-15-78$ & 18.67 & - \\
\hline $05-10-78$ & 17.01 & -- \\
\hline $08-23-78$ & 16.29 & -- \\
\hline $11-29-78$ & 17.68 & -- \\
\hline $02-21-79$ & 18.18 & -- \\
\hline $05-21-79$ & 15.71 & $S$ \\
\hline $09-19-79$ & 15.71 & $S$ \\
\hline $03-11-80$ & 17.38 & S \\
\hline $06-10-80$ & 14.20 & $S$ \\
\hline $07-14-81$ & 15.10 & $\mathrm{~S}$ \\
\hline $05-18-82$ & 15.78 & $\mathrm{~S}$ \\
\hline $08-24-82$ & 14.36 & S \\
\hline $10-12-83$ & 14.58 & $S$ \\
\hline $10-11-84$ & 15.09 & $\mathrm{~S}$ \\
\hline $10-30-86$ & 14.86 & $\mathrm{~S}$ \\
\hline $10-25-89$ & 14.80 & $\mathrm{~S}$ \\
\hline $09-13-90$ & 14.42 & $\mathrm{~S}$ \\
\hline $04-25-91$ & 16.12 & $\mathrm{~S}$ \\
\hline $09-17-91$ & 14.34 & $S$ \\
\hline $09-09-92$ & 14.78 & $\mathrm{~S}$ \\
\hline $03-10-94$ & 16.62 & $\mathbf{R}$ \\
\hline $06-16-94$ & 14.07 & $\mathbf{R}$ \\
\hline $09-27-94$ & 15.15 & $\mathbf{R}$ \\
\hline $12-20-94$ & 15.63 & $\mathbf{R}$ \\
\hline $03-23-95$ & 17.02 & $\mathbf{R}$ \\
\hline $06-27-95$ & 13.57 & $\mathbf{R}$ \\
\hline $09-28-95$ & 13.25 & $\mathrm{R}$ \\
\hline $12-19-95$ & 14.10 & $\mathbf{R}$ \\
\hline $03-14-96$ & 14.61 & $\mathrm{R}$ \\
\hline $06-04-96$ & 14.99 & $\mathrm{~T}$ \\
\hline $06-18-96$ & 13.39 & $\mathbf{R}$ \\
\hline $09-24-96$ & 13.92 & $\mathrm{R}$ \\
\hline $12-19-96$ & 14.55 & R \\
\hline $06-17-97$ & 13.50 & $\mathrm{R}$ \\
\hline $09-04-97$ & 13.68 & R \\
\hline
\end{tabular}

08N20W30CDAB01 cont.

$\begin{array}{ccc}\text { DATE } & \begin{array}{r}\text { WATER } \\ \text { LEVEL }\end{array} & \underline{\mathrm{MS}} \\ 09-27-94 & 19.09 & \mathrm{R} \\ 12-20-94 & 22.62 & \mathrm{R} \\ 03-23-95 & 26.06 & \mathrm{R} \\ 06-27-95 & 18.58 & \mathrm{R} \\ 09-28-95 & 16.58 & \mathrm{R} \\ 12-19-95 & 18.01 & \mathrm{R} \\ 03-14-96 & 19.17 & \mathrm{R} \\ 06-18-96 & 16.14 & \mathrm{R} \\ 09-24-96 & 15.94 & \mathrm{R} \\ 12-19-96 & 18.89 & \mathrm{R} \\ 06-17-97 & 15.46 & \mathrm{R} \\ 09-04-97 & 15.08 & \mathrm{R}\end{array}$

\section{N19W04BDAA01}

$\begin{array}{crc}\text { DATE } & \begin{array}{r}\text { WATER } \\ \text { LEVEL }\end{array} & \underline{\text { MS }} \\ 12-07-93 & 18.61 & \mathrm{R} \\ 03-09-94 & 17.63 & \mathrm{R} \\ 06-16-94 & 22.10 & \mathrm{R} \\ 09-27-94 & 14.85 & \mathrm{R} \\ 12-20-94 & 22.16 & \mathrm{R} \\ 03-23-95 & 22.25 & \mathrm{R} \\ 06-27-95 & 13.03 & \mathrm{R} \\ 09-28-95 & 13.28 & \mathrm{RR} \\ 12-19-95 & 18.01 & \mathrm{R} \\ 03-14-96 & 15.39 & \mathrm{R} \\ 06-18-96 & 17.78 & \mathrm{R} \\ 09-24-96 & 10.65 & \mathrm{R} \\ 12-19-96 & 17.94 & \mathrm{R} \\ 06-17-97 & 19.94 & \mathrm{R} \\ 09-04-97 & 9.72 & \mathrm{R} \\ & 17.80 & \mathrm{R}\end{array}$

\begin{tabular}{ccc}
\multicolumn{2}{c}{ 08N19W07CBBD01 } \\
\cline { 3 - 3 } DATE & WATER \\
L4-18-56 & LEVEL & MS \\
$05-07-56$ & 91.76 & -- \\
$06-05-56$ & 92.38 & - \\
$07-06-56$ & 93.20 & - \\
$08-06-56$ & 92.16 & - \\
$09-10-56$ & 89.34 & - \\
$10-01-56$ & 87.68 & - \\
$11-06-56$ & 85.74 & - \\
$12-05-56$ & 83.51 & - \\
$03-11-57$ & 84.65 & - \\
$04-12-57$ & 86.36 & - \\
$04-30-57$ & 87.66 & - \\
$06-11-57$ & 89.80 & - \\
$07-05-57$ & 89.49 & - \\
$08-13-57$ & 88.72 & - \\
$09-13-57$ & 87.50 & - \\
$10-04-57$ & 86.63 & - \\
$11-06-57$ & 85.31 & - \\
$12-06-57$ & 84.44 & - \\
$01-13-58$ & 84.66 & - \\
$02-03-58$ & 84.97 & - \\
$03-10-58$ & 87.08 & - \\
$04-02-58$ & 88.37 & - \\
$05-16-58$ & 90.88 & - \\
$05-30-58$ & 92.03 & - \\
$06-20-58$ & 92.80 & - \\
$06-28-58$ & 92.69 & - \\
$07-03-58$ & 93.05 & - \\
$07-11-58$ & 94.04 & - \\
$07-17-58$ & 94.03 & - \\
$07-25-58$ & 93.27 & - \\
$08-01-58$ & 92.98 & - \\
$08-08-58$ & 92.47 & --
\end{tabular}

08N19W07CBBD01 cont.

\begin{tabular}{|c|c|c|}
\hline DATE & $\begin{array}{l}\text { WATER } \\
\text { LEVEL }\end{array}$ & MS \\
\hline $08-15-58$ & 92.17 & 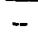 \\
\hline $08-22-58$ & 91.80 & 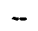 \\
\hline $08-29-58$ & 91.06 & - \\
\hline $09-05-58$ & 90.68 & - \\
\hline $09-12-58$ & 89.70 & - \\
\hline $09-19-58$ & 89.57 & - \\
\hline $09-26-58$ & 89.63 & - \\
\hline $10-03-58$ & 89.25 & - \\
\hline $10-10-58$ & 88.85 & - \\
\hline $10-17-58$ & 88.21 & -- \\
\hline $10-24-58$ & 88.72 & $-P$ \\
\hline $10-31-58$ & 87.70 & -- \\
\hline $11-07-58$ & 87.79 & -- \\
\hline $11-14-58$ & 87.47 & - \\
\hline $11-24-58$ & 87.00 & - \\
\hline $11-28-58$ & 87.52 & -- \\
\hline $12-05-58$ & 88.26 & - \\
\hline $12-12-58$ & 87.17 & -- \\
\hline $12-19-58$ & 87.04 & -- \\
\hline $12-26-58$ & 87.62 & -- \\
\hline $01-02-59$ & 86.92 & - \\
\hline $01-09-59$ & 87.18 & - \\
\hline 01-23-59 & 87.31 & - \\
\hline $01-30-59$ & 88.48 & - \\
\hline $02-06-59$ & 87.63 & -- \\
\hline $02-13-59$ & 88.59 & -- \\
\hline $02-20-59$ & 89.30 & - \\
\hline $02-27-59$ & 88.83 & - \\
\hline 03-13-59 & 91.04 & $-P$ \\
\hline $03-20-59$ & 89.88 & - \\
\hline $03-27-59$ & 90.01 & - \\
\hline $04-02-59$ & 90.70 & - \\
\hline $04-17-59$ & 91.47 & - \\
\hline 04-24-59 & 91.19 & -- \\
\hline $05-08-59$ & 92.04 & $-P$ \\
\hline $05-15-59$ & 92.37 & - \\
\hline $05-22-59$ & 93.17 & - \\
\hline $06-05-59$ & 93.82 & $-P$ \\
\hline $06-12-59$ & 94.06 & - \\
\hline $06-19-59$ & 94.50 & - \\
\hline $06-26-59$ & 94.64 & - \\
\hline $07-10-59$ & 95.49 & -- \\
\hline $07-17-59$ & 95.65 & - \\
\hline $07-23-59$ & 95.70 & - \\
\hline $07-31-59$ & 95.83 & -- \\
\hline 08-07-59 & 95.73 & -- \\
\hline $08-21-59$ & 94.90 & - \\
\hline $08-28-59$ & 95.01 & - \\
\hline $09-04-59$ & 94.47 & -- \\
\hline $09-18-59$ & 93.76 & $\cdots$ \\
\hline $09-25-59$ & 93.38 & - \\
\hline $10-02-59$ & 93.23 & - \\
\hline $10-09-59$ & 92.79 & - \\
\hline $10-16-59$ & 92.92 & - \\
\hline $10-23-59$ & 93.00 & - \\
\hline $11-27-59$ & 91.46 & - \\
\hline $12-04-59$ & 91.33 & - \\
\hline $12-11-59$ & 90.78 & -- \\
\hline $12-18-59$ & 90.96 & - \\
\hline $12-26-59$ & 91.14 & $\cdots$ \\
\hline $12-31-59$ & 90.65 & - \\
\hline $01-29-60$ & 91.65 & - \\
\hline $02-05-60$ & 91.77 & - \\
\hline $02-12-60$ & 92.27 & - \\
\hline $02-19-60$ & 92.39 & - \\
\hline $02-26-60$ & 92.62 & -- \\
\hline $03-11-60$ & 93.23 & - \\
\hline $03-18-60$ & 93.75 & - \\
\hline $03-25-60$ & 94.35 & - \\
\hline $04-01-60$ & 94.92 & - \\
\hline $04-08-60$ & 94.82 & - \\
\hline $04-15-60$ & 95.23 & - \\
\hline $04-22-60$ & 95.40 & - \\
\hline
\end{tabular}


Table 5. Records of water levels in wells (Continued)

08N19W07CBBD01 cont.

$\begin{array}{rrr} & \text { WATER } & \\ \text { DATE } & \text { LEVEL } & \text { MS } \\ 05-20-60 & 96.22 & -- \\ 05-27-60 & 97.65 & -- \\ 06-03-60 & 97.94 & -- \\ 06-17-60 & 98.06 & -- \\ 06-24-60 & 98.82 & -- \\ 07-01-60 & 99.32 & -\mathrm{P} \\ 07-08-60 & 100.66 & - \\ 07-15-60 & 100.84 & - \\ 07-29-60 & 100.06 & - \\ 08-05-60 & 99.87 & - \\ 09-09-60 & 98.14 & - \\ 10-07-60 & 96.15 & - \\ 11-04-60 & 95.57 & - \\ 12-02-60 & 93.85 & - \\ 02-06-61 & 93.89 & - \\ 03-03-61 & 95.00 & - \\ 03-31-61 & 96.32 & - \\ 05-02-61 & 98.38 & - \\ 06-02-61 & 99.60 & - \\ 07-05-61 & 100.60 & - \\ 08-04-61 & 99.86 & - \\ 03-02-62 & 97.87 & - \\ 08-27-62 & 102.16 & - \\ 03-04-63 & 95.87 & - \\ 09-11-63 & 95.77 & - \\ 03-13-64 & 91.87 & -- \\ 11-29-78 & 95.09 & -- \\ 02-21-79 & 94.56 & -- \\ 05-21-79 & 99.80 & -- \\ 09-19-79 & 97.66 & -- \\ 03-11-80 & 95.24 & - \\ 06-10-80 & 100.65 & \mathrm{~S} \\ 10-08-80 & 95.49 & \mathrm{~S} \\ 01-14-81 & 88.53 & \mathrm{~S} \\ 04-07-81 & 90.97 & \mathrm{~S} \\ 07-14-81 & 96.82 & \mathrm{~S} \\ 01-05-82 & 84.35 & \mathrm{~S} \\ 05-18-82 & 89.87 & \mathrm{~S} \\ 08-24-82 & 88.45 & \mathrm{~S} \\ 10-12-83 & 79.25 & \mathrm{~S} \\ 10-11-84 & 80.79 & \mathrm{~S} \\ 10-30-86 & 93.68 & \mathrm{~S} \\ 10-25-89 & 101.40 & \mathrm{~S} \\ 09-13-90 & 99.15 & \mathrm{~S} \\ 09-17-91 & 99.30 & \mathrm{~S} \\ 09-09-92 & 104.14 & \mathrm{~S} \\ 06-16-94 & 105.91 & \mathrm{R} \\ 09-27-94 & 101.81 & \mathrm{R} \\ 12-20-94 & 101.39 & \mathrm{R} \\ 03-23-95 & 101.34 & \mathrm{R} \\ 06-27-95 & 106.88 & \mathrm{R} \\ 08-22-95 & 107.04 & \mathrm{~S} \\ 09-28-95 & 102.45 & \mathrm{R} \\ 12-19-95 & 98.17 & \mathrm{R} \\ 03-14-96 & 97.14 & \mathrm{R} \\ 06-18-96 & 99.97 & \mathrm{R} \\ 12-19-96 & 90.60 & \mathrm{R} \\ 06-17-97 & 82.27 & \mathrm{R} \\ 09-04-97 & 83.33 & \mathrm{R} \\ & 76.49 & \mathrm{R}\end{array}$

\begin{tabular}{ccc}
\multicolumn{2}{c}{ 07N21 W36DDDC01 } & \\
& WATER & \\
DATE & LEVEL & MS \\
$08-27-93$ & 9.05 & R \\
$12-07-93$ & 12.01 & $\mathrm{R}$ \\
$03-09-94$ & 12.53 & $\mathrm{R}$ \\
$06-16-94$ & 8.46 & $\mathrm{R}$ \\
$09-27-94$ & 12.30 & $\mathrm{R}$ \\
$12-20-94$ & 12.28 & $\mathrm{R}$ \\
$03-23-95$ & 12.75 & $\mathrm{R}$
\end{tabular}

07N21W36DDDC01 cont.

\begin{tabular}{ccc} 
& WATER & \\
DATE & LEVEL & MS \\
$06-27-95$ & 8.78 & $\mathrm{R}$ \\
$09-28-95$ & 12.40 & $\mathrm{R}$ \\
$12-19-95$ & 12.52 & $\mathrm{R}$ \\
$03-14-96$ & 13.04 & $\mathrm{R}$ \\
$06-18-96$ & 7.74 & $\mathrm{R}$ \\
\multicolumn{2}{c}{ 07N20W32DDDA02 } &
\end{tabular}

$\begin{array}{crcc}\text { DATE } & \text { WATER } & & 08-24-95 \\ 06-26-72 & \text { LEVEL } & \text { MS } & 11-10-95 \\ 09-20-72 & 5.94 & \text { S } & 02-21-96 \\ 12-20-72 & 5.10 & \text { S } & 04-02-96 \\ 03-29-73 & 9.40 & \text { S } & 05-15-96 \\ 06-21-73 & 11.79 & \text { S } & 07-23-96 \\ 09-18-73 & 5.53 & \text { S } & 09-23-96 \\ 12-03-73 & 5.13 & \text { S } & 11-19-96 \\ 03-19-74 & 8.52 & \text { S } & 01-07-97 \\ 06-27-74 & 11.53 & \text { S } & 02-26-97 \\ 10-10-74 & 5.76 & \text { S } & 04-03-97 \\ 01-14-75 & 6.39 & \text { S } & 05-20-97 \\ 04-15-75 & 10.54 & \text { S } & 06-24-97 \\ 06-30-75 & 12.33 & \text { S } & 08-19-97 \\ 7.93 & S & 10-15-97\end{array}$

07N20W34CCCD01

\begin{tabular}{|c|c|}
\hline $\mathrm{AT}$ & WATER \\
\hline $08-23-95$ & 10.33 \\
\hline $11-10-95$ & 13.38 \\
\hline
\end{tabular}

\section{N20W34CDDB01*}

WATER

\begin{tabular}{cl} 
LEVEL & MS \\
\cline { 2 - 2 } 21.14 & SR \\
22.23 & S \\
28.17 & S \\
30.26 & S \\
31.70 & TR \\
20.56 & T \\
18.09 & T \\
23.13 & S \\
24.34 & S \\
27.50 & S \\
29.13 & S \\
32.39 & S \\
22.81 & S \\
28.57 & S \\
19.94 & S
\end{tabular}

06-30-75

08-26-75

11-24-75

02-10-76

05-26-76

$08-29-76$

11-10-76

02-14-77

09-21-77

12-20-77

$05-10-78$

08-23-78

11-29-78

02-21-79

05-21-79

09-19-79

03-11-80

06-10-80

10-07-80

01-14-81

04-07-81

$07-14-81$

01-05-82

05-18-82

08-24-82

07-23-91

08-25-93

12-07-93

03-09-94

06-16-94

09-27-94

12-20-94

03-23-95

06-27-95

08-21-95

$09-28-95$

12-19-95

03-14-96

$06-18-96$

09-24-96

12-19-96

5.93

8.44

11.41
8.24

8.24

4.94
8.19

11.56

5.54

4.93
9.68

10.72

4.03
9.48

11.52

8.28
5.90

11.68

7.92
6.48

10.91

13.21

6.14
9.46

11.05

5.41

7.03

4.16
8.47

12.20

7.04

5.99

10.10

12.75

6.62
5.85

5.37

5.37
8.97

11.12

7.44

5.49
9.40

9.40
6.51

09-04-97

19.94

\section{N21W01CBAB02*}

$\begin{array}{ccc} & \text { WATER } & \\ \text { DATE } & \text { LEVEL } & \text { MS } \\ 04-19-95 & 38.13 & \text { S } \\ 05-26-95 & 37.81 & \text { S } \\ 10-20-95 & 38.15 & \text { S } \\ 02-21-96 & 37.79 & \text { S } \\ 04-02-96 & 38.05 & \text { S } \\ 05-14-96 & 38.08 & \text { T } \\ 07-23-96 & 37.73 & \text { T } \\ 09-23-96 & 38.17 & \text { T } \\ 11-18-96 & 39.29 & \text { S } \\ 01-06-97 & 38.01 & \text { S } \\ 02-25-97 & 38.35 & \text { S } \\ 04-02-97 & 38.53 & \text { S } \\ 05-19-97 & 38.12 & \text { S } \\ 06-23-97 & 38.09 & \text { S } \\ 08-18-97 & 38.32 & \text { S } \\ 10-14-97 & 38.41 & \text { S }\end{array}$

\section{N21W02ABBD01*}

$\begin{array}{ccc}\text { DATE } & \begin{array}{c}\text { WATER } \\ \text { LEVEL }\end{array} & \text { MS } \\ 08-25-93 & 38.83 & \mathrm{R} \\ 12-07-93 & 49.10 & \mathrm{R} \\ 03-09-94 & 53.40 & \mathrm{R} \\ 06-16-94 & 43.62 & \mathrm{R} \\ 09-27-94 & 47.02 & \mathrm{R} \\ 12-20-94 & 52.54 & \mathrm{R} \\ 03-23-95 & 54.90 & \mathrm{R} \\ 06-27-95 & 39.58 & \mathrm{R} \\ 09-28-95 & 42.76 & \mathrm{R} \\ 12-19-95 & 42.18 & \mathrm{R} \\ 02-23-96 & 57.14 & \mathrm{SR} \\ 03-13-96 & 50.89 & \mathrm{R} \\ 04-02-96 & 56.38 & \mathrm{~S} \\ 05-14-96 & 56.21 & \mathrm{~T} \\ 06-18-96 & 45.58 & \mathrm{R} \\ 07-24-96 & 46.41 & \mathrm{~S} \\ 09-23-96 & 48.64 & \mathrm{~S} \\ 09-24-96 & 44.81 & \mathrm{R} \\ 11-18-96 & 53.56 & \mathrm{~S} \\ 12-19-96 & 52.03 & \mathrm{R} \\ 01-06-97 & 54.76 & \mathrm{~S} \\ 02-25-97 & 58.11 & \mathrm{~S} \\ 04-02-97 & & \mathrm{P}-\end{array}$


Table 5. Records of water levels in wells (Continued)

06N21W02ABBD01* cont.

$\begin{array}{ccc} & \text { WATER } & \\ \text { DATE } & \text { LEVEL } & \text { MS } \\ 05-19-97 & 53.56 & \text { S } \\ 06-17-97 & 44.39 & \text { R } \\ 06-23-97 & 47.16 & \text { S } \\ 08-18-97 & 45.37 & \text { S } \\ 09-04-97 & 41.98 & \text { R } \\ 10-14-97 & 50.75 & \text { S }\end{array}$

\section{N21W03ACBA01}

$\begin{array}{ccc} & \text { WATER } & \\ \text { DATE } & \text { LEVEL } & \text { MS } \\ 05-26-95 & 22.80 & \text { S } \\ 08-11-95 & 25.20 & \text { S } \\ 10-20-95 & 16.55 & \text { S }\end{array}$

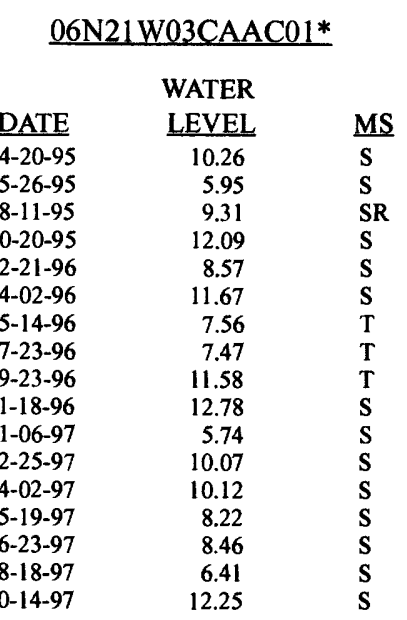

\section{N21W03CDAC01}

$\begin{array}{rcc}\text { DATE } & \text { WATER } & \\ 08-25-93 & \text { LEVEL } & \text { MS } \\ 12-07-93 & 34.62 & \mathrm{R} \\ 03-09-94 & 34.95 & \mathrm{R} \\ 06-16-94 & 35.39 & \mathrm{R} \\ 09-27-94 & 34.77 & \mathrm{R} \\ 12-20-94 & 35.74 & \mathrm{R} \\ 03-23-95 & 35.69 & \mathrm{R} \\ 06-27-95 & 35.63 & \mathrm{R} \\ 09-28-95 & 34.82 & \mathrm{R} \\ 12-19-95 & 35.01 & \mathrm{R} \\ 03-14-96 & 34.87 & \mathrm{R} \\ 06-18-96 & 34.02 & \mathrm{R} \\ 09-24-96 & 34.57 & \mathrm{R} \\ 12-19-96 & 33.91 & \mathrm{R} \\ 06-17-97 & 35.32 & \mathrm{R} \\ 09-04-97 & 34.59 & \mathrm{R} \\ & 34.77 & \mathrm{R}\end{array}$

\begin{tabular}{ccc}
\multicolumn{2}{c}{ 06N21 W03DDAA01* } \\
DATE & WATER & \\
LEVEL & MS \\
$04-20-95$ & 18.13 & S \\
$05-26-95$ & 16.68 & S \\
$08-11-95$ & 6.87 & S \\
$10-20-95$ & 15.11 & SR \\
$02-21-96$ & 6.25 & S \\
$04-02-96$ & 8.66 & S \\
$05-14-96$ & 9.31 & T \\
$07-23-96$ & 12.85 & T
\end{tabular}

06N21W03DDAA01* cont.

$\begin{array}{ccc}\text { DATE } & \begin{array}{c}\text { WATER } \\ \text { LEVEL }\end{array} & \underline{\text { MS }} \\ 09-23-96 & 14.96 & \mathrm{~T} \\ 11-18-96 & 19.86 & \mathrm{~S} \\ 01-06-97 & 18.10 & \mathrm{~S} \\ 02-25-97 & 11.88 & \mathrm{~S} \\ 04-02-97 & 6.54 & \mathrm{~S} \\ 05-19-97 & 16.58 & \mathrm{~S} \\ 06-23-97 & 8.01 & \mathrm{~S} \\ 08-18-97 & 11.23 & \mathrm{~S} \\ 10-14-97 & 16.35 & \mathrm{~S}\end{array}$

\section{N21W10BDDD01}

$\begin{array}{ccc} & \text { WATER } & \\ \text { DATE } & \text { LEVEL } & \text { MS } \\ 05-26-95 & 44.33 & \text { S } \\ 08-11-95 & 42.89 & \text { SR } \\ 10-20-95 & 45.75 & \text { SR }\end{array}$

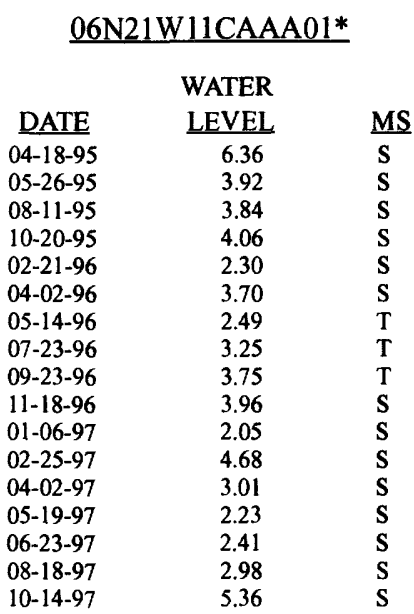

\section{N21W11CBCA01*}

$\begin{array}{ccc} & \text { WATER } & \\ \text { DATE } & \text { LEVEL } & \text { MS } \\ 04-19-95 & 15.39 & \mathrm{~S} \\ 05-26-95 & 9.13 & \mathrm{~S} \\ 08-11-95 & 11.86 & \mathrm{~S} \\ 10-20-95 & 14.03 & \mathrm{~S} \\ 02-21-96 & 13.89 & \mathrm{~S} \\ 04-02-96 & 12.78 & \mathrm{~S} \\ 05-14-96 & 14.54 & \mathrm{~T} \\ 07-23-96 & 12.58 & \mathrm{~T} \\ 09-23-96 & 12.98 & \mathrm{~T} \\ 11-18-96 & 13.62 & \mathrm{~S} \\ 01-06-97 & 12.75 & \mathrm{~S} \\ 02-25-97 & 14.53 & \mathrm{~S} \\ 04-02-97 & 14.28 & \mathrm{~S} \\ 05-19-97 & 15.40 & \mathrm{~S} \\ 06-23-97 & 13.11 & \mathrm{~S} \\ 08-18-97 & 12.88 & \mathrm{~S} \\ 10-14-97 & 13.53 & \mathrm{~S}\end{array}$

\begin{tabular}{ccc}
\multicolumn{3}{c}{ 06N21W11CBDC01* } \\
DATE & WATER & \\
LEVEL & MS \\
$04-19-95$ & 37.97 & S \\
$05-26-95$ & 38.10 & S \\
$08-11-95$ & 41.65 & SR \\
$10-20-95$ & 32.10 & S
\end{tabular}

06N21W11CBDC01* cont.

$\begin{array}{ccl} & \text { WATER } & \\ \text { DATE } & \text { LEVEL } & \text { MS } \\ 02-21-96 & 36.82 & \text { SR } \\ 04-02-96 & 38.47 & \text { S } \\ 05-14-96 & 34.29 & \text { T } \\ 07-23-96 & 30.35 & \text { T } \\ 09-23-96 & 61.40 & \text { TR } \\ 11-18-96 & 36.28 & \text { S } \\ 01-06-97 & 36.37 & \text { S } \\ 02-25-97 & 44.53 & \text { S } \\ 04-02-97 & 37.11 & \text { S } \\ 05-19-97 & 36.13 & \text { S } \\ 06-23-97 & 30.07 & \text { S } \\ 08-18-97 & 31.62 & \text { S } \\ 10-14-97 & 40.19 & \text { S }\end{array}$

\section{N21W11CDCB01}

$\begin{array}{ccc} & \text { WATER } & \\ \text { DATE } & \text { LEVEL } & \text { MS } \\ 08-11-95 & 14.62 & \mathrm{~S} \\ 10-20-95 & 14.40 & \mathrm{~S}\end{array}$

\section{N21W13BBAB01*}

\begin{tabular}{ccc} 
& WATER & \\
DATE & LEVEL & MS \\
\hline $04-18-95$ & 81.73 & $\mathrm{~S}$ \\
$05-26-95$ & 78.28 & $\mathrm{~S}$ \\
$08-11-95$ & 67.99 & $\mathrm{~S}$ \\
$10-20-95$ & 66.68 & $\mathrm{~S}$ \\
$02-21-96$ & 76.17 & $\mathrm{~S}$ \\
$04-02-96$ & 77.62 & $\mathrm{~S}$ \\
$05-14-96$ & 77.50 & $\mathrm{~T}$ \\
$07-23-96$ & 70.79 & $\mathrm{~T}$ \\
$09-23-96$ & 67.80 & $\mathrm{~T}$ \\
$11-18-96$ & 70.38 & $\mathrm{~S}$ \\
$01-06-97$ & 74.66 & $\mathrm{~S}$ \\
$02-25-97$ & 77.09 & $\mathrm{~S}$ \\
$04-02-97$ & 79.39 & $\mathrm{~S}$ \\
$05-19-97$ & 79.06 & $\mathrm{~S}$ \\
$06-23-97$ & 76.72 & $\mathrm{~S}$ \\
$08-18-97$ & 64.77 & $\mathrm{~S}$ \\
$10-14-97$ & 67.87 & $\mathrm{~S}$
\end{tabular}

\section{N21W14BDAC01*}

$\begin{array}{ccc} & \text { WATER } & \\ \underline{\text { DATE }} & \underline{\text { LEVEL }} & \underline{\mathrm{MS}} \\ 01-26-94 & 19.39 & \mathrm{~S} \\ 01-26-95 & 27.47 & \mathrm{~S} \\ 03-31-95 & 20.66 & \mathrm{~S} \\ 05-24-95 & 16.60 & \mathrm{~S} \\ 08-11-95 & 12.22 & \mathrm{~S} \\ 10-20-95 & 13.39 & \mathrm{~S} \\ 02-21-96 & 24.67 & \mathrm{~S} \\ 04-02-96 & 20.96 & \mathrm{~S} \\ 05-14-96 & 19.89 & \mathrm{~T} \\ 07-23-96 & 16.89 & \mathrm{TR} \\ 09-23-96 & 15.33 & \mathrm{~T} \\ 11-18-96 & 16.19 & \mathrm{~S} \\ 01-06-97 & 19.53 & \mathrm{~S} \\ 02-25-97 & 25.28 & \mathrm{~S} \\ 04-02-97 & 21.59 & \mathrm{~S} \\ 05-19-97 & 19.40 & \mathrm{~S} \\ 06-23-97 & 17.00 & \mathrm{~S} \\ 08-18-97 & 12.42 & \mathrm{~S} \\ 10-14-97 & 13.23 & \mathrm{~S}\end{array}$


Table 5. Records of water levels in wells (Continued)

$06 \mathrm{~N} 21 \mathrm{~W} 15 \mathrm{ABBB} 01$

$\begin{array}{ccl} & \text { WATER } & \\ \text { DATE } & \text { LEVEL } & \text { MS } \\ 05-26-95 & 111.33 & \text { S } \\ 08-11-95 & 108.46 & \text { SS } \\ 10-20-95 & 89.85 & \text { SS }\end{array}$

\section{N21W15ADBC01*}

$\begin{array}{ccc} & \text { WATER } & \\ \text { DATE } & \text { LEVEL } & \text { MS } \\ 06-12-95 & 133.93 & \mathrm{~S} \\ 08-11-95 & 138.15 & \mathrm{SR} \\ 10-2-95 & 135.60 & \mathrm{SR} \\ 02-21-96 & 134.49 & \mathrm{~S} \\ 04-02-96 & 136.09 & \mathrm{~S} \\ 05-14-96 & 135.69 & \mathrm{TR} \\ 07-23-96 & 144.35 & \mathrm{TR} \\ 09-23-96 & 131.08 & \mathrm{~T} \\ 11-18-96 & 136.02 & \mathrm{~S} \\ 01-06-97 & 136.57 & \mathrm{~S} \\ 02-25-97 & 134.70 & \mathrm{~S} \\ 04-02-97 & 132.04 & \mathrm{~S} \\ 05-19-97 & 126.43 & \mathrm{~S} \\ 06-23-97 & 124.88 & \mathrm{~S} \\ 08-18-97 & 131.60 & \mathrm{~S} \\ 10-14-97 & 146.60 & \mathrm{~S}\end{array}$

\section{N21 W15CDDD01*}

WATER

DATE

$10-26-94$
$01-26-95$

03-31-95

05-24-95

$08-11-95$

10-20-95

02-21-96

04-02-96

05-14-96

07-23-96

09-23-96

$11-18-96$

01-06-97

02-26-97

04-02-97

$05-19-97$

06-23-97

08-18-97

10-14-97

\begin{tabular}{cc} 
LEVEL & MS \\
\cline { 2 - 2 } 58.08 & S \\
67.65 & S \\
68.58 & S \\
60.32 & S \\
45.14 & S \\
44.87 & S \\
63.89 & S \\
64.33 & S \\
60.77 & T \\
41.48 & T \\
45.16 & T \\
51.91 & S \\
62.31 & S \\
65.87 & S \\
64.92 & S \\
53.37 & S \\
43.11 & S \\
46.31 & S \\
47.04 & S
\end{tabular}

06N21W21ADDB01*

$\begin{array}{ccc} & \text { WATER } & \\ \text { DATE } & \text { LEVEL } & \text { MS } \\ 10-25-94 & 130.69 & \mathrm{~S} \\ 01-25-95 & 133.41 & \mathrm{~S} \\ 03-30-95 & 135.27 & \mathrm{~S} \\ 05-23-95 & 136.52 & \mathrm{~S} \\ 08-10-95 & 133.97 & \mathrm{~S} \\ 10-20-95 & 129.19 & \mathrm{~S} \\ 02-21-96 & 133.03 & \mathrm{~S} \\ 04-02-96 & 135.70 & \mathrm{SR} \\ 05-14-96 & 133.65 & \mathrm{~S} \\ 07-23-96 & 134.01 & \mathrm{~T} \\ 09-23-96 & 128.87 & \mathrm{~S} \\ 11-18-96 & 127.67 & \mathrm{~S} \\ 01-06-97 & 130.29 & \mathrm{~S} \\ 02-25-97 & 131.91 & \mathrm{~S} \\ 04-02-97 & 133.25 & \mathrm{~S} \\ 05-19-97 & 133.74 & \mathrm{~S} \\ 06-23-97 & 133.29 & \mathrm{~S} \\ 08-18-97 & 129.62 & \mathrm{~S} \\ 10-14-97 & 124.77 & \mathrm{~S}\end{array}$

$\underline{06 \mathrm{~N} 21 \mathrm{~W} 22 \mathrm{BCCA} 01}$

$\begin{array}{ccc} & \text { WATER } & \\ \text { DATE } & \text { LEVEL } & \text { MS } \\ 01-25-95 & 98.96 & \text { SR } \\ 03-30-95 & 101.83 & \text { S } \\ 05-24-95 & 103.28 & \text { S } \\ 08-10-95 & 94.23 & \text { S } \\ 10-20-95 & 91.49 & \text { S }\end{array}$

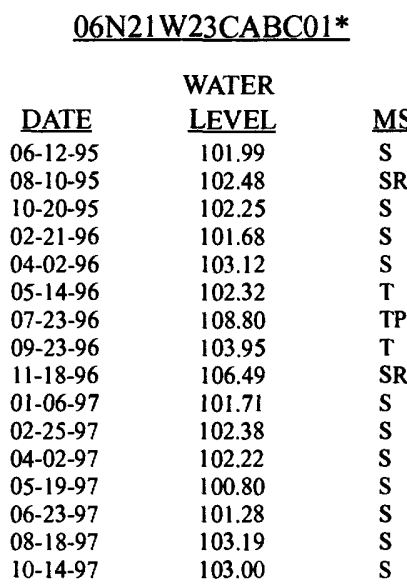

06N21W23CBCB01

$\begin{array}{ccc} & \text { WATER } & \\ \text { DATE } & \text { LEVEL } & \text { MS } \\ 01-25-95 & 96.59 & \text { S } \\ 03-30-95 & 97.04 & \text { S } \\ 05-24-95 & 97.47 & \text { S } \\ 08-10-95 & 94.82 & \text { S } \\ 10-20-95 & 94.92 & \text { S }\end{array}$

06N21W23CDCB01

$\begin{array}{ccl}\text { DATE } & \begin{array}{c}\text { WATER } \\ \text { LEVEL }\end{array} & \text { MS } \\ 01-25-95 & \frac{51.76}{\text { S }} \\ 03-30-95 & 53.23 & \text { SR } \\ 05-23-95 & 48.40 & \text { S } \\ 08-10-95 & 44.45 & \text { S } \\ 10-20-95 & 48.52 & \text { SR }\end{array}$

\section{N21W23DADA01}

$\begin{array}{ccc} & \text { WATER } & \\ \text { DATE } & \text { LEVEL } & \text { MS } \\ 01-25-95 & 17.17 & \text { S } \\ 03-30-95 & 17.24 & \text { S } \\ 05-24-95 & 5.89 & \text { S } \\ 08-08-95 & 3.05 & \text { S } \\ 10-20-95 & 5.22 & \text { S }\end{array}$

\begin{tabular}{ccc}
\multicolumn{2}{c}{ 06N21W23DADD01 } & \\
\multicolumn{3}{c}{ WATER } \\
DATE & LEVEL & MS \\
$01-26-95$ & 16.04 & S \\
$03-30-95$ & 16.17 & S \\
$05-24-95$ & 13.25 & S \\
$08-08-95$ & 4.89 & S \\
$10-20-95$ & 6.78 & S
\end{tabular}

06N21W23DDAD01

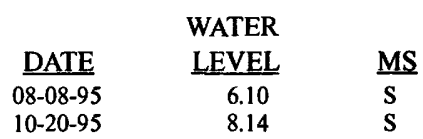

06N21W23DDBB01*

\begin{tabular}{|c|c|}
\hline DATE & $\begin{array}{l}\text { WATER } \\
\text { LEVEL }\end{array}$ \\
\hline $08-31-94$ & 5.52 \\
\hline $01-25-95$ & 9.81 \\
\hline $03-30-95$ & 9.86 \\
\hline $05-24-95$ & 6.23 \\
\hline $08-08-95$ & 3.85 \\
\hline $10-20-95$ & 4.69 \\
\hline $02-21-96$ & 5.68 \\
\hline $04-02-96$ & 8.02 \\
\hline $05-14-96$ & 8.33 \\
\hline $07-23-96$ & 3.44 \\
\hline $09-23-96$ & 5.65 \\
\hline $11-18-96$ & 7.94 \\
\hline $01-06-97$ & 2.91 \\
\hline $02-25-97$ & 7.22 \\
\hline $04-02-97$ & 8.12 \\
\hline $05-19-97$ & 6.55 \\
\hline $06-23-97$ & 3.84 \\
\hline $08-18-97$ & 4.26 \\
\hline $10-14-97$ & 5.53 \\
\hline
\end{tabular}

06N21 W23DDCB01

$\begin{array}{crl} & \text { WATER } & \\ \text { DATE } & \text { LEVEL } & \text { MS } \\ 01-25-95 & 6.55 & \text { S } \\ 03-30-95 & 6.99 & \text { S } \\ 05-24-95 & 5.55 & \text { S } \\ 08-08-95 & 3.22 & \text { S } \\ 10-20-95 & 3.52 & \text { SR }\end{array}$

\section{N21 W23DDDA01}

$\begin{array}{crc} & \text { WATER } & \\ \text { DATE } & \text { LEVEL } & \text { MS } \\ 01-25-95 & 9.48 & \text { S } \\ 03-30-95 & 9.75 & \text { S } \\ 05-24-95 & 7.82 & \text { S } \\ 08-08-95 & 3.44 & \text { S } \\ 10-20-95 & 4.38 & \text { S }\end{array}$

\section{N21W24BAAC01*}

\begin{tabular}{ccc} 
DATE & $\begin{array}{c}\text { WATER } \\
\text { LEVEL }\end{array}$ & MS \\
\hline $10-25-94$ & 17.77 & $\mathrm{~S}$ \\
$01-25-95$ & 18.65 & $\mathrm{~S}$ \\
$03-31-95$ & 18.97 & $\mathrm{~S}$ \\
$05-24-95$ & 18.07 & $\mathrm{~S}$ \\
$08-11-95$ & 17.86 & $\mathrm{~S}$ \\
$10-20-95$ & 17.71 & $\mathrm{~S}$ \\
$02-21-96$ & 18.41 & $\mathrm{SR}$ \\
$04-02-96$ & 19.69 & $\mathrm{SR}$ \\
$05-14-96$ & 18.63 & $\mathrm{~T}$ \\
$07-23-96$ & 17.68 & $\mathrm{~T}$ \\
$09-23-96$ & 17.95 & $\mathrm{~T}$ \\
$11-18-96$ & 18.01 & $\mathrm{~S}$ \\
$01-06-97$ & 16.68 & $\mathrm{~S}$ \\
$02-25-97$ & 18.41 & $\mathrm{~S}$ \\
$04-02-97$ & 18.90 & $\mathrm{~S}$ \\
$05-19-97$ & 17.83 & $\mathrm{~S}$ \\
$06-23-97$ & 20.02 & $\mathrm{~S}$ \\
$08-18-97$ & 17.83 & $\mathrm{~S}$ \\
$10-14-97$ & 17.83 & $\mathrm{~S}$
\end{tabular}


Table 5. Records of water levels in wells (Continued)

06N21W24BDCC01

$\begin{array}{ccc} & \text { WATER } & \\ \text { DATE } & \text { LEVEL } & \text { MS } \\ 05-26-95 & 58.28 & \mathrm{~S} \\ 08-11-95 & 58.18 & \mathrm{~S} \\ 10-20-95 & 54.92 & \mathrm{~S}\end{array}$

\section{N21W24CCACO1*}

$\begin{array}{ccc} & \text { WATER } & \\ \text { DATE } & \text { LEVEL } & \text { M } \\ 08-31-94 & 21.11 & \text { S } \\ 01-25-95 & 25.88 & \text { S } \\ 03-30-95 & 26.50 & \text { S } \\ 05-24-95 & 27.65 & \text { S } \\ 08-08-95 & 19.29 & \text { S } \\ 10-20-95 & 20.83 & \text { S } \\ 02-21-96 & 22.33 & \text { S } \\ 04-02-96 & 23.76 & \text { S } \\ 05-14-96 & 24.18 & \text { T } \\ 07-23-96 & 19.57 & \text { T } \\ 09-23-96 & 22.39 & \text { T } \\ 11-18-96 & 23.57 & \text { S } \\ 01-06-97 & 20.09 & \text { S } \\ 02-25-97 & 20.67 & \text { S } \\ 04-02-97 & 23.62 & \text { S } \\ 05-19-97 & 23.91 & \text { S } \\ 06-23-97 & 19.84 & \text { S } \\ 08-18-97 & 20.63 & \text { S } \\ 10-14-97 & 22.65 & \text { S }\end{array}$

\section{N21W24CCBB02}

$\begin{array}{crl} & \text { WATER } & \\ \text { DATE } & \text { LEVEL } & \text { MS } \\ 01-25-95 & 15.56 & \text { S } \\ 03-30-95 & 15.78 & \text { S } \\ 05-24-95 & 16.33 & \text { SS } \\ 08-08-95 & 7.37 & \text { SS } \\ 10-20-95 & 7.41 & \text { S }\end{array}$

10-20-95

\section{N21W26AADD01}

$\begin{array}{ccc}\text { DATE } & \begin{array}{c}\text { WATER } \\ \text { LEVEL }\end{array} & \text { MS } \\ 01-26-95 & 38.89 & \text { S } \\ 03-30-95 & 37.98 & \text { S } \\ 05-24-95 & 36.26 & \text { S } \\ 08-10-95 & 36.67 & \text { S } \\ 10-20-95 & 35.98 & \text { S }\end{array}$

\section{N21W26ABAD01*}

$\begin{array}{ccc}\text { DATE } & \begin{array}{c}\text { WATER } \\ \text { LEVEL }\end{array} & \text { MS } \\ 08-18-94 & 37.14 & \mathrm{~S} \\ 01-25-95 & 38.98 & \mathrm{~S} \\ 03-31-95 & 40.54 & \mathrm{~S} \\ 05-24-95 & 36.46 & \mathrm{~S} \\ 08-10-95 & 36.53 & \mathrm{~S} \\ 10-20-95 & 36.58 & \mathrm{~S} \\ 02-21-96 & 37.59 & \mathrm{~S} \\ 04-02-96 & 38.43 & \mathrm{~S} \\ 05-14-96 & 37.01 & \mathrm{~T} \\ 07-23-96 & 36.11 & \mathrm{~T} \\ 09-23-96 & 38.84 & \mathrm{~S} \\ 04-02-97 & 37.06 & \mathrm{~S} \\ 05-19-97 & 36.39 & \mathrm{~S} \\ 06-23-97 & 45.04 & \mathrm{~S} \\ 08-18-97 & 36.99 & \mathrm{~S} \\ 10-14-97 & 39.84 & \mathrm{~S}\end{array}$

06N21W26BBCA01

$\begin{array}{ccc}\text { DATE } & \begin{array}{c}\text { WATER } \\ \text { LEVEL }\end{array} & \text { MS } \\ 01-25-95 & 36.85 & \text { S } \\ 03-30-95 & 37.32 & \text { S } \\ 05-23-95 & 37.68 & \text { S } \\ 08-10-95 & 32.74 & \text { S } \\ 10-20-95 & 34.54 & \text { S }\end{array}$

\section{N21W26CBAB01}

\begin{tabular}{|c|c|c|}
\hline & WATER & \\
\hline DATE & LEVEL & $\underline{\mathrm{MS}}$ \\
\hline $01-25-95$ & 17.49 & S \\
\hline $03-30-95$ & 15.68 & \\
\hline $05-23-95$ & 16.29 & SI \\
\hline 08-09-95 & 14.73 & SR \\
\hline $10-20-95$ & 15.14 & \\
\hline
\end{tabular}

\section{N21W26DBAD01*}

$\begin{array}{ccc} & \text { WATER } & \\ \text { DATE } & \text { LEVEL } & \text { MS } \\ 08-25-93 & 30.35 & \mathrm{R} \\ 12-07-93 & 32.27 & \mathrm{R} \\ 03-08-94 & 33.68 & \mathrm{R} \\ 06-16-94 & 32.75 & \mathrm{R} \\ 09-13-94 & 32.52 & \mathrm{~S} \\ 09-27-94 & 32.93 & \mathrm{R} \\ 12-20-94 & 34.38 & \mathrm{R} \\ 0 \mathrm{I}-25-95 & 34.51 & \mathrm{~S} \\ 03-23-95 & 34.25 & \mathrm{R} \\ 03-30-95 & 34.37 & \mathrm{~S} \\ 05-23-95 & 33.60 & \mathrm{~S} \\ 06-27-95 & 32.52 & \mathrm{R} \\ 08-09-95 & 32.48 & \mathrm{~S} \\ 09-27-95 & 32.18 & \mathrm{R} \\ 10-20-95 & 32.60 & \mathrm{~S} \\ 12-19-95 & 31.37 & \mathrm{R} \\ 02-21-96 & 30.13 & \mathrm{~S} \\ 03-14-96 & 31.10 & \mathrm{R} \\ 04-02-96 & 31.49 & \mathrm{~S} \\ 05-14-96 & 31.46 & \mathrm{~S} \\ 06-18-96 & 30.61 & \mathrm{R} \\ 07-23-96 & 31.63 & \mathrm{~S} \\ 09-23-96 & 31.64 & \mathrm{~S} \\ 09-24-96 & 32.57 & \mathrm{R} \\ 11-18-96 & 36.21 & \mathrm{~S} \\ 12-19-96 & 33.50 & \mathrm{R} \\ 0 \mathrm{I}-06-97 & 31.45 & \mathrm{~T} \\ 02-25-97 & 31.21 & \mathrm{~S} \\ 04-02-97 & 32.16 & \mathrm{~S} \\ 05-19-97 & 31.87 & \mathrm{~S} \\ 06-17-97 & 30.54 & \mathrm{R} \\ 06-23-97 & 30.93 & \mathrm{~S} \\ 08-18-97 & 31.82 & \mathrm{~S} \\ 09-04-97 & 32.20 & \mathrm{R} \\ 10-14-97 & 32.95 & \mathrm{~S}\end{array}$

\section{N21W26DBDD01}

WATER

$\begin{array}{ccl}\text { DATE } & \text { LEVEL } & \text { MS } \\ 01-25-95 & 38.08 & \text { S } \\ 03-30-95 & 38.02 & \text { S } \\ 05-23-95 & 38.28 & \text { S } \\ 08-09-95 & 39.11 & \text { SR } \\ 10-20-95 & 37.74 & \text { S }\end{array}$

06N21W27ADBC01*

\begin{tabular}{ccl} 
DATE & $\begin{array}{c}\text { WATER } \\
\text { LEVEL }\end{array}$ & MS \\
\cline { 2 - 2 } $08-29-94$ & 45.04 & $\mathrm{~S}$ \\
$01-25-95$ & 46.39 & $\mathrm{~S}$ \\
$03-30-95$ & 48.23 & $\mathrm{SZ}$ \\
$05-24-95$ & 47.52 & $\mathrm{~S}$ \\
$08-10-95$ & 46.12 & $\mathrm{~S}$ \\
$10-20-95$ & 44.38 & $\mathrm{~S}$ \\
$02-21-96$ & 44.25 & $\mathrm{~S}$ \\
$04-02-96$ & 45.53 & $\mathrm{~S}$ \\
$05-14-96$ & 44.32 & $\mathrm{~T}$ \\
$07-23-96$ & 42.47 & $\mathrm{~T}$ \\
$09-23-96$ & 44.03 & $\mathrm{~T}$ \\
$11-18-96$ & 44.67 & $\mathrm{~T}$ \\
$01-06-97$ & 45.05 & $\mathrm{~T}$ \\
$02-25-97$ & 43.91 & $\mathrm{~S}$ \\
$04-02-97$ & 43.57 & $\mathrm{~S}$ \\
$05-19-97$ & 44.55 & $\mathrm{~S}$ \\
$06-23-97$ & 43.25 & $\mathrm{~S}$ \\
$08-18-97$ & 43.03 & $\mathrm{~S}$ \\
$10-14-97$ & 42.71 & $\mathrm{~S}$
\end{tabular}

06N21W27BABA01

WATER

$\begin{array}{ccc}\text { DATE } & \text { LEVEL } & \text { MS } \\ 01-25-95 & 66.89 & \text { S } \\ 03-30-95 & 66.78 & \text { S } \\ 05-23-95 & 67.65 & \text { S } \\ 08-10-95 & 74.42 & \text { SR } \\ 10-20-95 & 66.34 & \text { SR }\end{array}$

06N21W27BBAA01

WATER

DATE

08-25-93

12-07-93

03-08-94

06-16-94

09-27-94

12-20-94

03-23-95

06-27-95

09-27-95

12-19-95

03-14-96

06-18-96

09-24-96

12-19-96

06-17-97

09-04-97

\begin{tabular}{cl} 
LEVEL & MS \\
\hline 81.23 & R \\
81.10 & $\mathrm{R}$ \\
80.76 & $\mathrm{R}$ \\
82.17 & $\mathrm{R}$ \\
83.99 & $\mathrm{RP}$ \\
81.80 & $\mathrm{R}$ \\
83.55 & $\mathrm{R}$ \\
81.95 & $\mathrm{R}$ \\
80.95 & $\mathrm{R}$ \\
81.27 & $\mathrm{R}$ \\
86.28 & $\mathrm{R}$ \\
81.64 & $\mathrm{R}$ \\
82.00 & $\mathrm{R}$ \\
80.95 & $\mathrm{R}$ \\
82.13 & $\mathrm{R}$ \\
79.18 & $\mathrm{R}$
\end{tabular}

06N20W01BABA01

WATER

$\begin{array}{ccc}\text { DATE } & \text { LEVEL } & \text { MS } \\ 08-24-95 & 8.08 & \text { SR } \\ 05-15-96 & 21.77 & T\end{array}$

06N20W01BABB01*

$\begin{array}{ccc} & \text { WATER } & \\ \text { DATE } & \text { LEVEL } & \text { MS } \\ 07-26-95 & 10.63 & \text { S } \\ 08-24-95 & 9.64 & \text { S } \\ 11-10-95 & 13.20 & \text { S } \\ 02-21-96 & 19.11 & \text { S } \\ 04-02-96 & 28.67 & \text { SR } \\ 05-15-96 & 37.35 & \text { TR } \\ 07-23-96 & 11.13 & \text { T } \\ 09-23-96 & 8.42 & \text { T }\end{array}$


Table 5. Records of water levels in wells (Continued)

06N20W01BABB01* cont.

$\begin{array}{ccc} & \text { WATER } & \\ \text { DATE } & \text { LEVEL } & \text { MS } \\ 01-07-97 & 16.43 & \text { S } \\ 02-26-97 & 17.61 & \text { S } \\ 04-03-97 & 19.17 & \text { S } \\ 05-20-97 & 29.85 & \text { S } \\ 06-24-97 & 15.23 & \text { S } \\ 08-19-97 & 10.85 & \text { S } \\ 10-15-97 & 11.41 & \text { S }\end{array}$

\begin{tabular}{ccc}
\multicolumn{2}{c}{ 06N20W01CDCD01* } \\
\cline { 2 - 3 } & \multicolumn{1}{c}{ WATER } \\
DATE & LEVEL & MS \\
$06-14-95$ & 5.49 & S \\
$08-23-95$ & 4.05 & S \\
$11-10-95$ & 4.55 & S \\
$02-22-96$ & 8.31 & SR \\
$04-03-96$ & 8.42 & S \\
$05-15-96$ & 5.99 & $\mathrm{~T}$ \\
$07-24-96$ & 3.88 & $\mathrm{~T}$ \\
$09-23-96$ & 3.11 & $\mathrm{~T}$ \\
$01-07-97$ & 5.72 & $\mathrm{~S}$ \\
$02-26-97$ & 7.87 & $\mathrm{~S}$ \\
$04-03-97$ & 7.84 & $\mathrm{~S}$ \\
$05-20-97$ & 3.52 & $\mathrm{~S}$ \\
$06-24-97$ & 4.31 & $\mathrm{~S}$ \\
$08-19-97$ & 3.96 & $\mathrm{~S}$ \\
$10-15-97$ & 4.26 & $\mathrm{~S}$
\end{tabular}

\begin{tabular}{ccc}
\multicolumn{3}{c}{ 06N20W02AADC01 } \\
WATER \\
DATE & LEVEL & MS \\
$08-23-95$ & 33.87 & S \\
$11-10-95$ & 45.25 & S
\end{tabular}

\begin{tabular}{ccc}
\multicolumn{3}{c}{ 06N20W02BBDA01 } \\
WATER \\
DATE & LEVEL & MS \\
$08-23-95$ & 3.64 & $\mathrm{~S}$ \\
$11-10-95$ & 7.93 & $\mathrm{~S}$
\end{tabular}

\begin{tabular}{ccc}
\multicolumn{2}{c}{ 06N20W02DCDC01* } \\
\cline { 3 - 3 } DATE & WATER & \\
LEVEL & MS \\
$07-12-95$ & M.90 & S \\
$08-23-95$ & 7.09 & S \\
$11-10-95$ & 8.23 & S \\
$02-22-96$ & 7.62 & S \\
$04-02-96$ & 7.85 & S \\
$05-15-96$ & 7.99 & $\mathrm{~T}$ \\
$07-24-96$ & 8.25 & $\mathrm{~T}$ \\
$09-23-96$ & 8.13 & $\mathrm{~T}$ \\
$11-19-96$ & 14.52 & $\mathrm{~S}$ \\
$01-07-97$ & 6.76 & $\mathrm{~S}$ \\
$02-26-97$ & 8.26 & $\mathrm{~S}$ \\
$04-03-97$ & 7.84 & $\mathrm{~S}$ \\
$05-20-97$ & 8.06 & $\mathrm{~S}$ \\
$06-24-97$ & 7.61 & $\mathrm{~S}$ \\
$08-19-97$ & 6.77 & $\mathrm{~S}$ \\
$10-15-97$ & 7.14 & $\mathrm{~S}$
\end{tabular}

06N20W03BDBB01

$\begin{array}{ccc} & \text { WATER } & \\ \text { DATE } & \text { LEVEL } & \text { MS } \\ 08-23-95 & 17.43 & \text { S } \\ 11-10-95 & 17.52 & \text { S }\end{array}$

06N20W03BDCC01

$\begin{array}{ccc} & \text { WATER } & \\ \text { DATE } & \text { LEVEL } & \text { MS } \\ 08-25-93 & 22.93 & \text { R } \\ 12-07-93 & 19.40 & \text { R } \\ 03-09-94 & 32.77 & \text { R } \\ 06-16-94 & 30.56 & \text { R }\end{array}$

\section{N20W03BDCC01}

\begin{tabular}{|c|c|}
\hline DATE & $\begin{array}{l}\text { WATER } \\
\text { LEVEL }\end{array}$ \\
\hline $09-27-94$ & 21.97 \\
\hline $12-20-94$ & 27.73 \\
\hline $03-23-95$ & 32.78 \\
\hline $06-27-95$ & 31.91 \\
\hline $08-24-95$ & 24.23 \\
\hline $09-28-95$ & 21.41 \\
\hline $11-11-95$ & 22.61 \\
\hline $12-19-95$ & 23.68 \\
\hline $03-14-96$ & 29.10 \\
\hline $06-18-96$ & 28.69 \\
\hline $09-24-96$ & 20.94 \\
\hline $12-19-96$ & 25.58 \\
\hline $06-17-97$ & 27.03 \\
\hline $09-04-97$ & 19.52 \\
\hline
\end{tabular}

\section{N20W04AABC01}

$\begin{array}{ccc} & \text { WATER } & \\ \text { DATE } & \frac{\text { LEVEL }}{08-24-95} & \underline{\text { MS }} \\ 11-10-95 & 7.96 & \mathrm{~S} \\ & 7.26 & \mathrm{~S}\end{array}$

\begin{tabular}{ccc}
\multicolumn{3}{c}{ 06N20W04ACCD01 } \\
& WATER & \\
DATE & $\frac{\text { LEVEL }}{32.13}$ & $\frac{\text { MS }}{\mathrm{S}}$ \\
$08-24-95$ & 34.02 & $\mathrm{~S}$
\end{tabular}

\section{N20W04ADCD01*}

$\begin{array}{ccc} & \text { WATER } & \\ \text { DATE } & \underline{\text { LEVEL }} & \text { MS } \\ 06-14-95 & 24.93 & \mathrm{~S} \\ 02-22-96 & 23.74 & \mathrm{~S} \\ 04-02-96 & 25.14 & \mathrm{~S} \\ 05-15-96 & 25.89 & \mathrm{~T} \\ 07-23-96 & 20.66 & \mathrm{~T} \\ 09-23-96 & 18.87 & \mathrm{~T} \\ 11-19-96 & 21.13 & \mathrm{~S} \\ 01-07-97 & 21.99 & \mathrm{~S} \\ 02-26-97 & 23.57 & \mathrm{~S} \\ 04-03-97 & 24.84 & \mathrm{~S} \\ 05-20-97 & 26.27 & \mathrm{~S} \\ 06-24-97 & 19.82 & \mathrm{~S} \\ 08-19-97 & 19.64 & \mathrm{~S} \\ 10-15-97 & 21.03 & \mathrm{~S}\end{array}$

\section{N20W04CCCD01}

$\begin{array}{ccc} & \text { WATER } & \\ \text { DATE } & \text { LEVEL } & \text { MS } \\ 08-24-95 & 15.91 & \text { S } \\ 11-10-95 & 19.67 & \text { S }\end{array}$

06N20W04DCCB01*

$\begin{array}{ccc} & \text { WATER } & \\ \text { DATE } & \frac{\text { LEVEL }}{36.94} & \underline{\mathrm{MS}} \\ 06-15-95 & 33.09 & \mathrm{~S} \\ 08-24-95 & 35.00 & \mathrm{~S} \\ 11-10-95 & 38.00 & \mathrm{~S} \\ 02-21-96 & 38.05 & \mathrm{~S} \\ 04-02-96 & 39.49 & \mathrm{TR} \\ 05-15-96 & 33.30 & \mathrm{~T} \\ 07-23-96 & 32.76 & \mathrm{~T} \\ 09-23-96 & 35.56 & \mathrm{~S} \\ 11-19-96 & 36.64 & \mathrm{~S} \\ 01-07-97 & 37.73 & \mathrm{~S} \\ 02-26-97 & 38.62 & \mathrm{~S} \\ 04-03-97 & 38.97 & \mathrm{~S} \\ 05-20-97 & 34.03 & \mathrm{~S} \\ 06-24-97 & 33.43 & \mathrm{~S} \\ 08-19-97 & 33.55 & \mathrm{~S} \\ 10-15-97 & & \end{array}$

\section{N20W09BDDD01}

$\begin{array}{ccc} & \text { WATER } & \\ \text { DATE } & \text { LEVEL } & \text { MS } \\ 08-24-95 & 49.07 & \mathrm{~S} \\ 11-10-95 & 49.44 & \mathrm{~S}\end{array}$

\section{N20W09CBCC01*}

$\begin{array}{ccl}\text { DATE } & \begin{array}{c}\text { WATER } \\ \text { LEVEL }\end{array} & \text { MS } \\ 08-03-95 & 55.81 & \mathrm{~S} \\ 08-24-95 & 54.49 & \mathrm{~S} \\ 11-10-95 & 60.35 & \mathrm{SR} \\ 02-21-96 & 63.83 & \mathrm{~S} \\ 04-02-96 & 65.99 & \mathrm{~S} \\ 05-15-96 & 63.89 & \mathrm{~T} \\ 07-23-96 & 59.18 & \mathrm{TR} \\ 09-23-96 & 55.26 & \mathrm{~T} \\ 11-19-96 & 60.92 & \mathrm{~S} \\ 01-07-97 & 62.44 & \mathrm{~S} \\ 02-26-97 & 63.64 & \mathrm{~S} \\ 04-02-97 & 64.39 & \mathrm{~S} \\ 05-20-97 & 65.02 & \mathrm{~S} \\ 06-24-97 & 60.91 & \mathrm{~S} \\ 08-19-97 & 56.84 & \mathrm{~S} \\ 10-14-97 & 57.75 & \mathrm{~S}\end{array}$

\section{N20W09CCDB01}

$\begin{array}{ccc} & \text { WATER } & \\ \text { DATE } & \text { LEVEL } & \text { MS } \\ 08-24-95 & 62.56 & \mathrm{~S} \\ 11-10-95 & 67.74 & \mathrm{~S}\end{array}$

06N20W09DCAB01

$\begin{array}{ccc} & \text { WATER } & \\ \text { DATE } & \text { LEVEL } & \text { MS } \\ 08-24-95 & 35.87 & \mathrm{~S} \\ 11-10-95 & 36.00 & \mathrm{~S}\end{array}$

\section{N20W10AADC01*}

$\begin{array}{ccc}\text { DATE } & \begin{array}{c}\text { WATER } \\ \text { LEVEL }\end{array} & \text { MS } \\ 07-12-95 & 21.84 & \text { S } \\ 11-10-95 & 27.80 & \text { S } \\ 02-21-96 & 32.86 & \text { S } \\ 04-02-96 & 36.84 & \text { SR } \\ 05-15-96 & 32.82 & \text { T } \\ 07-23-96 & 21.96 & \text { T } \\ 09-23-96 & 15.86 & \text { T }\end{array}$


Table 5. Records of water levels in wells (Continued)

06N20W10AADC01* cont.

$\begin{array}{ccc} & \text { WATER } & \\ \text { DATE } & \text { LEVEL } & \text { MS } \\ 11-19-96 & 28.32 & \mathrm{~S} \\ 01-07-97 & 32.38 & \mathrm{~S} \\ 02-26-97 & 29.50 & \mathrm{~S} \\ 04-03-97 & 30.87 & \mathrm{~S} \\ 05-20-97 & 30.03 & \mathrm{~S} \\ 06-24-97 & 27.24 & \mathrm{~S} \\ 08-19-97 & 21.56 & \mathrm{~S} \\ 10-14-97 & 22.67 & \mathrm{~S}\end{array}$

\section{N20W10ABDB01}

$\begin{array}{ccc} & \text { WATER } \\ \text { DATE } & \text { LEVEL } & \text { MS } \\ 08-24-95 & \frac{\text { ME }}{11.58} & \mathrm{~S} \\ 11-10-95 & 15.68 & \mathrm{~S}\end{array}$

\begin{tabular}{ccc}
\multicolumn{2}{c}{ 06N20W10CACB01* } \\
DATE & WATER & \\
$06-14-95$ & LEVEL & MS \\
$08-24-95$ & 140.00 & $\mathrm{~S}$ \\
$11-10-95$ & 139.25 & $\mathrm{~S}$ \\
$02-21-96$ & 137.32 & $\mathrm{~S}$ \\
$04-02-96$ & 137.06 & $\mathrm{~S}$ \\
$05-15-96$ & 138.19 & $\mathrm{~S}$ \\
$07-23-96$ & 138.57 & $\mathrm{~S}$ \\
$09-23-96$ & 138.63 & $\mathrm{~S}$ \\
$11-19-96$ & 137.24 & $\mathrm{~S}$ \\
$01-07-97$ & 136.99 & $\mathrm{~S}$ \\
$02-26-97$ & 138.11 & $\mathrm{~S}$ \\
$04-02-97$ & 137.32 & $\mathrm{~S}$ \\
$05-20-97$ & 138.19 & $\mathrm{~S}$ \\
$06-24-97$ & 140.48 & $\mathrm{~S}$ \\
$08-19-97$ & 139.76 & $\mathrm{~S}$ \\
$10-14-97$ & 141.51 & $\mathrm{~S}$ \\
& 140.26 & $\mathrm{~S}$
\end{tabular}
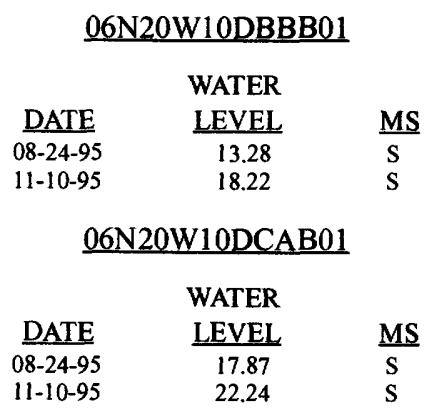

\section{N20W12CCCD01*}

\begin{tabular}{|c|c|}
\hline DATE & $\begin{array}{l}\text { WATER } \\
\text { LEVEL }\end{array}$ \\
\hline $05-04-95$ & 38.58 \\
\hline $08-23-95$ & 23.10 \\
\hline $11-10-95$ & 29.54 \\
\hline $02-22-96$ & 32.86 \\
\hline $04-02-96$ & 33.67 \\
\hline $05-15-96$ & 35.36 \\
\hline $07-24-96$ & 23.17 \\
\hline $09-24-96$ & 24.73 \\
\hline $11-19-96$ & 29.95 \\
\hline $01-07-97$ & 32.09 \\
\hline $02-26-97$ & 32.34 \\
\hline $04-03-97$ & 33.81 \\
\hline $05-20-97$ & 34.96 \\
\hline $06-24-97$ & 25.18 \\
\hline $08-19-97$ & 21.23 \\
\hline $10-15-97$ & 27.30 \\
\hline
\end{tabular}

06N20W14ACDD01*

$\begin{array}{ccc}\text { DATE } & \begin{array}{c}\text { WATER } \\ \text { LEVEL }\end{array} & \underline{\text { MS }} \\ 02-22-96 & 67.99 & \text { SR } \\ 04-02-96 & 66.45 & \mathrm{~S} \\ 05-15-96 & 69.70 & \mathrm{~T} \\ 07-24-96 & 67.23 & \mathrm{~T} \\ 09-24-96 & 64.90 & \mathrm{~T} \\ 11-19-96 & 67.58 & \mathrm{~S} \\ 01-07-97 & 67.19 & \mathrm{~S} \\ 02-26-97 & 67.35 & \mathrm{~S} \\ 04-03-97 & 68.13 & \mathrm{~S} \\ 05-20-97 & 68.98 & \mathrm{~S} \\ 06-24-97 & 66.82 & \mathrm{~S} \\ 08-19-97 & 66.86 & \mathrm{~S} \\ 10-15-97 & 66.00 & \mathrm{~S}\end{array}$

06N20W14BADB01*

$\begin{array}{ccl}\text { DATE } & \begin{array}{c}\text { WATER } \\ \text { LEVEL }\end{array} & \text { MS } \\ 05-02-95 & \frac{27.26}{\mathrm{~S}} & \mathrm{~S} \\ 11-23-95 & 11.17 & \mathrm{~S} \\ 02-22-95 & 14.21 & \mathrm{SR} \\ 04-03-96 & 17.02 & \mathrm{~S} \\ 05-15-96 & 19.28 & \mathrm{~S} \\ 07-24-96 & 17.15 & \mathrm{~T} \\ 09-24-96 & 10.41 & \mathrm{~T} \\ 01-07-97 & 11.73 & \mathrm{~T} \\ 02-26-97 & 13.20 & \mathrm{~S} \\ 04-03-97 & 15.97 & \mathrm{~S} \\ 05-20-97 & 16.83 & \mathrm{~S} \\ 06-24-97 & 15.32 & \mathrm{~S} \\ 08-19-97 & 11.29 & \mathrm{~S} \\ 10-15-97 & 10.96 & \mathrm{~S} \\ & 12.67 & \mathrm{~S}\end{array}$

06N20W14BBBB01

$\begin{array}{ccc}\text { DATE } & \begin{array}{c}\text { WATER } \\ \text { LEVEL }\end{array} & \frac{\mathrm{MS}}{\mathrm{0}-25-93} \\ 12-07-93 & 66.97 & \mathrm{R} \\ 03-09-94 & 66.25 & \mathrm{R} \\ 06-16-94 & 88.57 & \mathrm{R} \\ 03-23-95 & 68.32 & \mathrm{R} \\ 06-27-95 & 68.27 & \mathrm{R} \\ 09-28-95 & 68.68 & \mathrm{R} \\ 12-19-95 & 66.61 & \mathrm{R} \\ 03-14-96 & 66.80 & \mathrm{R} \\ 06-18-96 & 67.78 & \mathrm{R} \\ 09-24-96 & 68.31 & \mathrm{R} \\ 12-19-96 & 66.34 & \mathrm{R} \\ 06-17-97 & 66.60 & \mathrm{R} \\ 09-04-97 & 67.60 & \mathrm{R} \\ & 66.94 & \mathrm{R}\end{array}$

\section{N20W14CAAA01}

$\begin{array}{ccc} & \text { WATER } & \\ \text { DATE } & \frac{\text { LEVEL }}{8.22} & \underline{\mathrm{MS}} \\ 08-23-95 & \mathrm{~S} \\ 11-10-95 & 15.56 & \mathrm{SR}\end{array}$

\section{N20W14DAAA01*}

$\begin{array}{ccl}\frac{\text { WATER }}{\text { DATE }} & \begin{array}{l}\text { LEVEL } \\ 08-21-95\end{array} & \frac{\text { MS }}{\mathrm{S}} \\ 02-22-96 & 97.59 & \mathrm{~S} \\ 04-02-96 & 99.18 & \mathrm{SR} \\ 05-15-96 & 99.24 & \mathrm{~S} \\ 07-24-96 & 95.89 & \mathrm{~T} \\ 09-24-96 & 93.13 & \mathrm{~T} \\ 01-07-97 & 96.18 & \mathrm{~T}\end{array}$

06N20W14DAAA01* cont.

$\begin{array}{ccc} & \text { WATER } & \\ \text { DATE } & \text { LEVEL } & \text { MS } \\ 02-26-97 & 96.67 & \mathrm{~S} \\ 04-03-97 & 98.04 & \mathrm{~S} \\ 05-20-97 & 98.82 & \mathrm{~S} \\ 06-24-97 & 96.06 & \mathrm{~S} \\ 08-19-97 & 90.67 & \mathrm{~S} \\ 10-15-97 & 90.15 & \mathrm{~S}\end{array}$

\section{N20W15AACD01*}

$\begin{array}{ccc}\text { DATE } & \begin{array}{c}\text { WATER } \\ \text { LEVEL }\end{array} & \text { MS } \\ 08-24-95 & 29.99 & \mathrm{~S} \\ 11-10-95 & 30.62 & \mathrm{~S} \\ 02-21-96 & 31.80 & \mathrm{~S} \\ 04-03-96 & 33.00 & \mathrm{~S} \\ 05-15-96 & 33.01 & \mathrm{~T} \\ 07-24-96 & 30.90 & \mathrm{~T} \\ 09-24-96 & 30.50 & \mathrm{~T} \\ 11-19-96 & 30.30 & \mathrm{~S} \\ 01-07-97 & 31.69 & \mathrm{~S} \\ 02-26-97 & 31.25 & \mathrm{~S} \\ 04-03-97 & 31.86 & \mathrm{~S} \\ 05-20-97 & 32.64 & \mathrm{~S} \\ 06-24-97 & 25.93 & \mathrm{~S} \\ 08-19-97 & 31.71 & \mathrm{~S} \\ 10-15-97 & 32.96 & \mathrm{~S}\end{array}$

\section{N20W15BBCC01}

$\begin{array}{ccc} & \text { WATER } & \\ \text { DATE } & \text { LEVEL } & \text { MS } \\ 08-23-95 & 62.29 & \mathrm{~S} \\ 11-10-95 & 61.15 & \mathrm{~S}\end{array}$

\section{N20W15CACC01*}

$\begin{array}{ccl}\text { DATE } & \begin{array}{c}\text { WATER } \\ \text { LEVEL }\end{array} & \underline{\text { MS }} \\ 07-25-95 & 21.35 & \mathrm{~S} \\ 08-23-95 & 19.88 & \mathrm{~S} \\ 11-10-95 & 21.73 & \mathrm{~S} \\ 02-22-96 & 25.10 & \mathrm{~S} \\ 04-03-96 & 26.12 & \mathrm{~S} \\ 05-15-96 & 26.91 & \mathrm{TR} \\ 07-24-96 & 19.91 & \mathrm{~T} \\ 09-24-96 & 18.30 & \mathrm{~T} \\ 11-19-96 & 21.87 & \mathrm{SR} \\ 01-07-97 & 22.87 & \mathrm{~S} \\ 02-26-97 & 22.89 & \mathrm{~S} \\ 04-03-97 & 26.24 & \mathrm{~S} \\ 05-20-97 & 25.77 & \mathrm{~S} \\ 06-24-97 & 19.62 & \mathrm{~S} \\ 08-19-97 & 24.89 & \mathrm{~S} \\ 10-15-97 & 24.94 & \mathrm{~S}\end{array}$

\section{N20W16ACCB01}

$\begin{array}{ccc}\text { DATE } & \text { WATER } & \\ 08-24-95 & \frac{}{\text { LEVEL }} & \text { MS } \\ 11-10-95 & 74.83 & \text { S } \\ \text { SR }\end{array}$

\section{N20W16ADCB01*}

$\begin{array}{ccc} & \text { WATER } & \\ \text { DATE } & \text { LEVEL } & \text { MS } \\ 07-27-95 & 75.01 & \text { S } \\ 08-23-95 & 75.99 & \text { S } \\ 11-10-95 & 73.19 & \text { S } \\ 02-22-96 & 75.00 & \text { SR } \\ 04-03-96 & 75.71 & \text { S }\end{array}$


Table 5. Records of water levels in wells (Continued)

06N20W16ADCB01* cont.

$\begin{array}{ccc}\text { DATE } & \begin{array}{c}\text { WATER } \\ \text { LEVEL }\end{array} & \text { MS } \\ 05-15-96 & \frac{76.05}{7 R} & \text { TR } \\ 07-24-96 & 76.55 & \text { TR } \\ 09-24-96 & 71.52 & \text { T } \\ 11-19-96 & 72.97 & \mathrm{~S} \\ 01-07-97 & 74.18 & \mathrm{~S} \\ 02-26-97 & 74.47 & \mathrm{~S} \\ 04-03-97 & 78.30 & \mathrm{~S} \\ 05-20-97 & 79.36 & \mathrm{~S} \\ 06-24-97 & 75.86 & \mathrm{~S} \\ 08-19-97 & 73.12 & \mathrm{~S} \\ 10-15-97 & 72.26 & \mathrm{~S}\end{array}$

\section{N20W16BAAD01*}

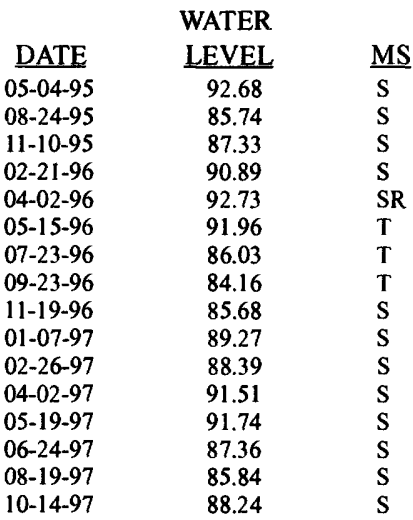

\section{N20W19 CCCCO2}

\begin{tabular}{|c|c|c|}
\hline DATE & LEVEL & MS \\
\hline $09-10-70$ & 5.78 & -- \\
\hline $09-28-70$ & 7.20 & -- \\
\hline $10-26-70$ & 10.05 & 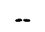 \\
\hline $11-23-70$ & 12.09 & - \\
\hline $12-23-70$ & 13.60 & - \\
\hline $01-17-71$ & 15.85 & $\mathrm{~S}$ \\
\hline $01-26-71$ & 14.28 & - \\
\hline $02-17-71$ & 14.99 & $\mathrm{~S}$ \\
\hline $02-22-71$ & 15.12 & -- \\
\hline $03-25-71$ & 15.77 & $\mathrm{~S}$ \\
\hline $04-27-71$ & 15.85 & - \\
\hline $05-24-71$ & 8.97 & - \\
\hline $06-24-71$ & 6.06 & - \\
\hline $07-21-71$ & 6.16 & -- \\
\hline $08-24-71$ & 6.24 & .. \\
\hline $09-22-71$ & 6.35 & - \\
\hline $10-26-71$ & 9.80 & -- \\
\hline $11-23-71$ & 11.78 & -. \\
\hline $12-23-71$ & 13.20 & - \\
\hline $01-27-72$ & 13.53 & - \\
\hline $02-22-72$ & 14.24 & -- \\
\hline $03-27-72$ & 14.22 & -- \\
\hline $04-24-72$ & 14.79 & -- \\
\hline $05-25-72$ & 10.15 & -. \\
\hline $06-22-72$ & 6.18 & -. \\
\hline $07-24-72$ & 5.83 & - \\
\hline $08-23-72$ & 5.72 & -- \\
\hline $09-21-72$ & 6.58 & -- \\
\hline $10-26-72$ & 9.32 & -. \\
\hline $11-28-72$ & 11.78 & -- \\
\hline $12-26-72$ & 13.04 & -- \\
\hline $01-25-73$ & 14.01 & -- \\
\hline $02-26-73$ & 15.04 & -- \\
\hline $03-27-73$ & 15.89 & . \\
\hline
\end{tabular}

06N20W19CCCC02 cont.

06N20W19CCCC02 cont.

\begin{tabular}{|c|c|c|c|c|c|}
\hline & WATER & & & WATER & \\
\hline DATE & LEVEL & $\underline{\text { MS }}$ & DATE & LEVEL & MS \\
\hline $03-29-73$ & 16.01 & -- & $1 \overline{11-28-78}$ & 12.85 & - \\
\hline $04-26-73$ & 16.87 & - & $12-19-78$ & 14.13 & - \\
\hline $05-25-73$ & 9.59 & - & $01-25-79$ & 15.82 & - \\
\hline $06-26-73$ & 5.94 & - & $02-21-79$ & 15.67 & - \\
\hline $07-24-73$ & 5.57 & - & $03-27-79$ & 16.35 & - \\
\hline $08-27-73$ & 5.88 & - & $04-25-79$ & 16.65 & -- \\
\hline $09-18-73$ & 6.95 & - & $05-24-79$ & 14.38 & - \\
\hline $09-26-73$ & 7.44 & - & $06-25-79$ & 5.96 & - \\
\hline $10-24-73$ & 10.48 & -- & $07-25-79$ & 6.33 & - \\
\hline $11-27-73$ & 11.77 & -- & $08-29-79$ & 5.52 & - \\
\hline $12-03-73$ & 12.05 & -- & $10-11-79$ & 8.54 & $\mathrm{~S}$ \\
\hline $12-20-73$ & 12.85 & - & $11-20-79$ & 12.01 & $\mathrm{~S}$ \\
\hline $01-28-74$ & 13.17 & -- & $12-20-79$ & 13.67 & - \\
\hline $02-25-74$ & 13.60 & -- & $01-16-80$ & 13.76 & $\mathrm{~S}$ \\
\hline $03-19-74$ & 14.27 & -- & $01-22-80$ & 14.13 & - \\
\hline $03-25-74$ & 14.47 & -- & $02-26-80$ & 15.43 & $\mathbf{S}$ \\
\hline $04-24-74$ & 15.40 & -- & $04-08-80$ & 16.43 & $\mathrm{~S}$ \\
\hline $05-29-74$ & 7.57 & - & $04-21-80$ & 16.74 & - \\
\hline $06-19-74$ & 5.95 & -- & $06-06-80$ & 6.52 & $S$ \\
\hline $07-24-74$ & 6.45 & - & $07-24-80$ & 6.17 & S \\
\hline $08-26-74$ & 5.41 & - & $09-03-80$ & 6.62 & $\mathrm{~S}$ \\
\hline $09-25-74$ & 7.60 & -- & $09-23-80$ & 6.84 & -- \\
\hline $10-23-74$ & 9.72 & -- & $10-16-80$ & 9.11 & $\mathrm{~S}$ \\
\hline $11-20-74$ & 11.80 & - & $12-02-80$ & 12.97 & $\mathrm{~S}$ \\
\hline $12-20-74$ & 13.60 & -- & $02-26-81$ & 16.45 & -. \\
\hline $01-22-75$ & 15.27 & -- & $03-05-81$ & 16.59 & $\mathrm{~S}$ \\
\hline $02-24-75$ & 16.20 & - & $04-14-81$ & 17.25 & $\mathrm{~S}$ \\
\hline $03-25-75$ & 16.72 & -- & $04-21-81$ & 17.34 & -- \\
\hline $04-23-75$ & 17.39 & -- & $05-20-81$ & 12.42 & -. \\
\hline $05-21-75$ & 17.42 & -- & $06-24-81$ & 6.96 & $\mathrm{~S}$ \\
\hline $06-21-75$ & 6.52 & -- & $09-16-81$ & 6.61 & $\mathrm{~S}$ \\
\hline $07-28-75$ & 5.77 & -- & $09-22-81$ & 6.57 & - \\
\hline $08-22-75$ & 6.01 & -- & $11-04-81$ & 10.88 & $\mathrm{~S}$ \\
\hline $09-24-75$ & 8.16 & -- & $12-16-81$ & 13.36 & $\mathrm{~S}$ \\
\hline $10-28-75$ & 10.20 & -- & $01-27-82$ & 14.68 & $\mathrm{~S}$ \\
\hline $11-21-75$ & 11.82 & -- & $02-26-82$ & 15.00 & - \\
\hline $12-22-75$ & 13.27 & -- & $03-08-82$ & 15.07 & $\mathrm{~S}$ \\
\hline $01-22-76$ & 14.42 & -- & $04-20-82$ & 16.67 & $\mathbf{S}$ \\
\hline $02-23-76$ & 15.54 & -- & $05-28-82$ & 8.35 & $\mathrm{~S}$ \\
\hline $03-24-76$ & 16.16 & - & $07-13-82$ & 6.69 & $\mathrm{~S}$ \\
\hline $04-20-76$ & 16.68 & -- & $08-24-82$ & 6.94 & $\mathrm{~S}$ \\
\hline $05-24-76$ & 14.66 & -- & $10-07-82$ & 7.57 & $\mathrm{~S}$ \\
\hline $06-21-76$ & 5.19 & -- & II-I6-82 & 11.55 & $\mathrm{~S}$ \\
\hline $07-22-76$ & 5.60 & -- & $12-28-82$ & 13.90 & $\mathrm{~S}$ \\
\hline $08-20-76$ & 6.03 & -- & $02-08-83$ & 15.45 & $\mathrm{~S}$ \\
\hline $09-23-76$ & 7.42 & - & $05-04-83$ & 17.81 & $\mathrm{~S}$ \\
\hline $10-21-76$ & 10.20 & -- & $07-07-83$ & 6.48 & $\mathrm{~S}$ \\
\hline $11-18-76$ & 12.40 & - & $08-02-83$ & 5.82 & $\mathrm{~S}$ \\
\hline $12-22-76$ & 14.32 & - & $09-13-83$ & 7.27 & $\mathrm{~S}$ \\
\hline $01-24-77$ & 15.70 & -- & $11-03-83$ & 11.27 & $\mathbf{S}$ \\
\hline $02-22-77$ & 16.60 & - & $12-14-83$ & 13.63 & $\mathrm{~S}$ \\
\hline $03-28-77$ & 17.35 & - & $03-13-84$ & 16.68 & $\mathrm{~S}$ \\
\hline $04-26-77$ & 17.86 & - & $04-24-84$ & 17.28 & $\mathrm{~S}$ \\
\hline $05-25-77$ & 9.74 & -- & $06-06-84$ & 7.92 & $\mathrm{~S}$ \\
\hline $06-21-77$ & 5.80 & -- & $07-17-84$ & 6.75 & $\mathrm{~S}$ \\
\hline $07-26-77$ & 5.55 & -- & $08-28-84$ & 6.97 & $\mathrm{~S}$ \\
\hline $08-23-77$ & 6.00 & - & $10-10-84$ & 8.70 & $\mathbf{S}$ \\
\hline $09-20-77$ & 7.14 & -- & II $-27-84$ & $\mathrm{I} 2.58$ & $\mathbf{S}$ \\
\hline $10-20-77$ & 9.74 & - & $01-17-85$ & 15.37 & $\mathrm{~S}$ \\
\hline $11-17-77$ & 12.28 & -- & $01-23-85$ & 15.57 & $\mathbf{S}$ \\
\hline $12-20-77$ & 13.81 & -. & $03-01-85$ & 16.44 & $\mathrm{~S}$ \\
\hline $01-20-78$ & 14.85 & -- & $03-06-85$ & 16.54 & $\mathrm{~S}$ \\
\hline $02-15-78$ & 15.68 & $\mathrm{~S}$ & $05-22-85$ & 14.41 & $\mathrm{~S}$ \\
\hline $02-22-78$ & 15.88 & -- & $08-15-85$ & 6.35 & - \\
\hline $03-23-78$ & 16.60 & -- & $10-01-85$ & 8.86 & $\mathrm{~S}$ \\
\hline $04-24-78$ & 17.12 & -- & $11-14-85$ & 12.15 & $\mathrm{~S}$ \\
\hline $05-10-78$ & 17.08 & $\mathrm{~S}$ & $01-09-86$ & 15.19 & $\mathrm{~S}$ \\
\hline $05-24-78$ & 13.78 & -- & $02-19-86$ & 15.46 & $\mathrm{~S}$ \\
\hline $06-26-78$ & 6.51 & -- & $04-10-86$ & 16.28 & $\mathrm{~S}$ \\
\hline $07-20-78$ & 6.28 & -- & $05-29-86$ & 9.80 & $\mathrm{~S}$ \\
\hline $08-23-78$ & 6.19 & -- & $11-19-86$ & 12.74 & $\mathrm{~S}$ \\
\hline $09-21-78$ & 7.01 & - & $02-18-87$ & 16.22 & $\mathrm{~S}$ \\
\hline $10-19-78$ & 9.72 & -- & $03-24-87$ & 16.81 & 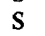 \\
\hline
\end{tabular}


Table 5. Records of water levels in wells (Continued)

\section{N20W19CCCC02 cont.}

\begin{tabular}{|c|c|c|c|c|c|}
\hline \multicolumn{3}{|c|}{ WATER } & \multicolumn{3}{|c|}{ WATER } \\
\hline DATE & LEVEL & $\underline{\mathrm{MS}}$ & DATE & LEVEL & $\underline{\mathrm{MS}}$ \\
\hline $05-07-87$ & 16.25 & $\mathbf{S}$ & $11-26-96$ & 12.58 & $\mathbf{S}$ \\
\hline $06-09-87$ & 7.37 & $\mathbf{S}$ & $01-07-97$ & 12.45 & $\mathrm{~S}$ \\
\hline $09-10-87$ & 6.70 & $\mathbf{S}$ & & & \\
\hline $10-27-87$ & 10.50 & $\mathbf{S}$ & \multicolumn{3}{|c|}{ 06N20W29BADB01 } \\
\hline $12-02-87$ & 13.20 & $\mathbf{S}$ & \multirow{2}{*}{\multicolumn{3}{|c|}{ WATER }} \\
\hline $04-12-88$ & 17.34 & $\mathbf{S}$ & & & \\
\hline $06-28-88$ & 6.85 & $\mathbf{S}$ & DATE & LEVEL & MS \\
\hline $07-13-88$ & 6.47 & $\mathbf{S}$ & $08-25-93$ & 11.87 & $\mathrm{R}$ \\
\hline $08-17-88$ & 6.73 & $\mathbf{S}$ & $12-07-93$ & 15.75 & $\begin{array}{l}\mathbf{R} \\
\mathbf{R}\end{array}$ \\
\hline $09-27-88$ & 7.48 & $\mathbf{S}$ & $\begin{array}{l}12-07-93 \\
03-09-94\end{array}$ & 18.80 & $\begin{array}{l}\mathrm{K} \\
\mathrm{RR}\end{array}$ \\
\hline $10-27-88$ & 10.72 & $\mathbf{S}$ & & 15.03 & $\begin{array}{l}\mathbf{R R} \\
\mathbf{R}\end{array}$ \\
\hline $12-21-88$ & 14.13 & $\mathbf{S}$ & $06-16-94$ & 1367 & $\begin{array}{l}\mathrm{R} \\
\mathrm{D}\end{array}$ \\
\hline $02-10-89$ & 16.04 & $\mathbf{S}$ & $09-27-94$ & 13.67 & $\mathrm{R}$ \\
\hline $03-15-89$ & 16.26 & $\mathbf{S}$ & $12-20-94$ & 17.72 & $\mathbf{R}$ \\
\hline $05-04-89$ & 16.08 & $\mathbf{S}$ & $03-23-95$ & 17.75 & $\mathbf{R}$ \\
\hline $07-26-89$ & 6.54 & $\mathbf{S}$ & $06-27-95$ & 15.46 & $\mathbf{R}$ \\
\hline $09-13-89$ & 7.06 & S & $09-27-95$ & 13.84 & $\mathbf{R}$ \\
\hline $10-24-89$ & 10.31 & $\mathbf{S}$ & $12-19-95$ & 16.81 & $\mathbf{R}$ \\
\hline $12-05-89$ & 13.07 & S & $03-14-96$ & 18.34 & $\mathbf{R}$ \\
\hline $01-23-90$ & 15.40 & S & $06-18-96$ & 15.69 & $\mathbf{R}$ \\
\hline $03-06-90$ & 16.48 & S & $09-24-96$ & 12.54 & $\mathbf{R}$ \\
\hline $04-17-90$ & 17.20 & $\mathbf{S}$ & $12-19-96$ & 15.00 & $\mathbf{R}$ \\
\hline $05-30-90$ & 8.22 & $\mathbf{S}$ & $06-16-97$ & 13.87 & $\mathbf{R}$ \\
\hline
\end{tabular}

06N20W19CCCC02 cont.

14.10

\section{N19W07BABC01*}

$10-10-90 \quad 9.12$

$11-27-90 \quad 12.77$

01-14-91 $\quad 15.02$

02-25-91 $\quad 16.34$

04-02-91 $\quad 16.95$

05-28-91 $\quad 10.87$

06-25-91 $\quad 6.53$

08-07-91

10-01-91

$11-13-91$

02-04-92

03-24-92

05-05-92

06-17-92

09-08-92

10-19-92

12-02-92

02-23-93

$06-29-93$

$08-12-93$

10-04-93

10-21-93

$02-01-94$

06-01-94

$10-04-94$

02-10-95

03-21-95

$05-10-95$

07-25-95

10-18-95

12-13-95

02-13-96

05-15-96

08-08-96

10-03-96

$08-23-95 \quad 23.16$

09-28-95 26.28

11-10-95 26.45

$12-19-95 \quad 28.88$

02-22-96 $\quad 31.01$

03-14-96 28.50

04-03-96 29.55

05-15-96 26.97

06-18-96 24.38

07-24-96 24.32

09-23-96 25.74

09-24-96 26.36

$11-19-96 \quad 26.79$

$12-19-96 \quad 27.47$

01-07-97 26.44

02-26-97 28.08

04-03-97 28.12

05-20-97 26.09

$06-17-97 \quad 27.30$

06-24-97 23.71

08-19-97 23.95

09-04-97 25.06

10-15-97
05N20W30BDCD01

\begin{tabular}{ccc} 
DATE & $\begin{array}{c}\text { WATER } \\
\text { LEVEL }\end{array}$ & $\underline{\text { MS }}$ \\
\hline $08-24-93$ & 21.81 & $\mathrm{R}$ \\
$12-07-93$ & 16.80 & $\mathrm{R}$ \\
$03-08-94$ & 27.52 & $\mathrm{R}$ \\
$06-15-94$ & 20.76 & $\mathrm{R}$ \\
$09-26-94$ & 21.96 & $\mathrm{R}$ \\
$12-20-94$ & 24.93 & $\mathrm{R}$ \\
$03-23-95$ & 21.88 & $\mathrm{R}$ \\
$06-27-95$ & 22.37 & $\mathrm{RP}$ \\
$09-27-95$ & 20.17 & $\mathrm{R}$ \\
$12-19-95$ & 22.42 & $\mathrm{R}$ \\
$03-14-96$ & 23.59 & $\mathrm{R}$ \\
$06-17-96$ & 22.95 & $\mathrm{R}$ \\
$09-24-96$ & 22.20 & $\mathrm{R}$ \\
$12-19-96$ & 24.44 & $\mathrm{R}$ \\
$06-16-97$ & 22.04 & $\mathrm{R}$ \\
$09-04-97$ & 22.48 & $\mathrm{R}$
\end{tabular}

\section{N21W15CBBB01}

$\begin{array}{ccc} & \text { WATER } & \\ \underline{\text { DATE }} & \text { LEVEL } & \text { MS } \\ 08-24-93 & 67.38 & \mathrm{R} \\ 12-07-93 & 70.95 & \mathrm{R} \\ 03-08-94 & 75.45 & \mathrm{R} \\ 06-15-94 & 72.28 & \mathrm{R} \\ 09-26-94 & 68.85 & \mathrm{R} \\ 12-20-94 & 75.43 & \mathrm{R} \\ 03-22-95 & 77.43 & \mathrm{R} \\ 06-26-95 & 72.01 & \mathrm{R} \\ 09-27-95 & 66.41 & \mathrm{R} \\ 12-19-95 & 69.84 & \mathrm{R} \\ 03-13-96 & 71.88 & \mathrm{R} \\ 06-17-96 & 70.61 & \mathrm{R}\end{array}$

\section{N21W15CBBB01}

WATER

DATE

09-23-96

12-18-96

06-16-97

09-04-97

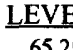

65.29

71.78

67.30

63.50

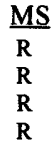

\section{N21W01CACD01}

$\begin{array}{ccc}\frac{\text { WATE }}{\text { DAT-08-94 }} & \begin{array}{c}\text { LEVEL } \\ 06-15-94\end{array} & \underline{\mathrm{MS}} \\ 09-26-94 & 25.76 & \mathrm{R} \\ 12-20-94 & 19.67 & \mathrm{R} \\ 03-22-95 & 25.50 & \mathrm{R} \\ 06-26-95 & 26.96 & \mathrm{R} \\ 09-27-95 & 23.98 & \mathrm{R} \\ 12-19-95 & 18.02 & \mathrm{R} \\ 03-13-96 & 24.00 & \mathrm{R} \\ 06-17-96 & 25.39 & \mathrm{R} \\ 09-23-96 & 26.32 & \mathrm{R} \\ 12-18-96 & 16.64 & \mathrm{R} \\ 06-16-97 & 22.14 & \mathrm{R} \\ 09-04-97 & 17.49 & \mathrm{R} \\ 0 & 13.06 & \mathrm{R}\end{array}$



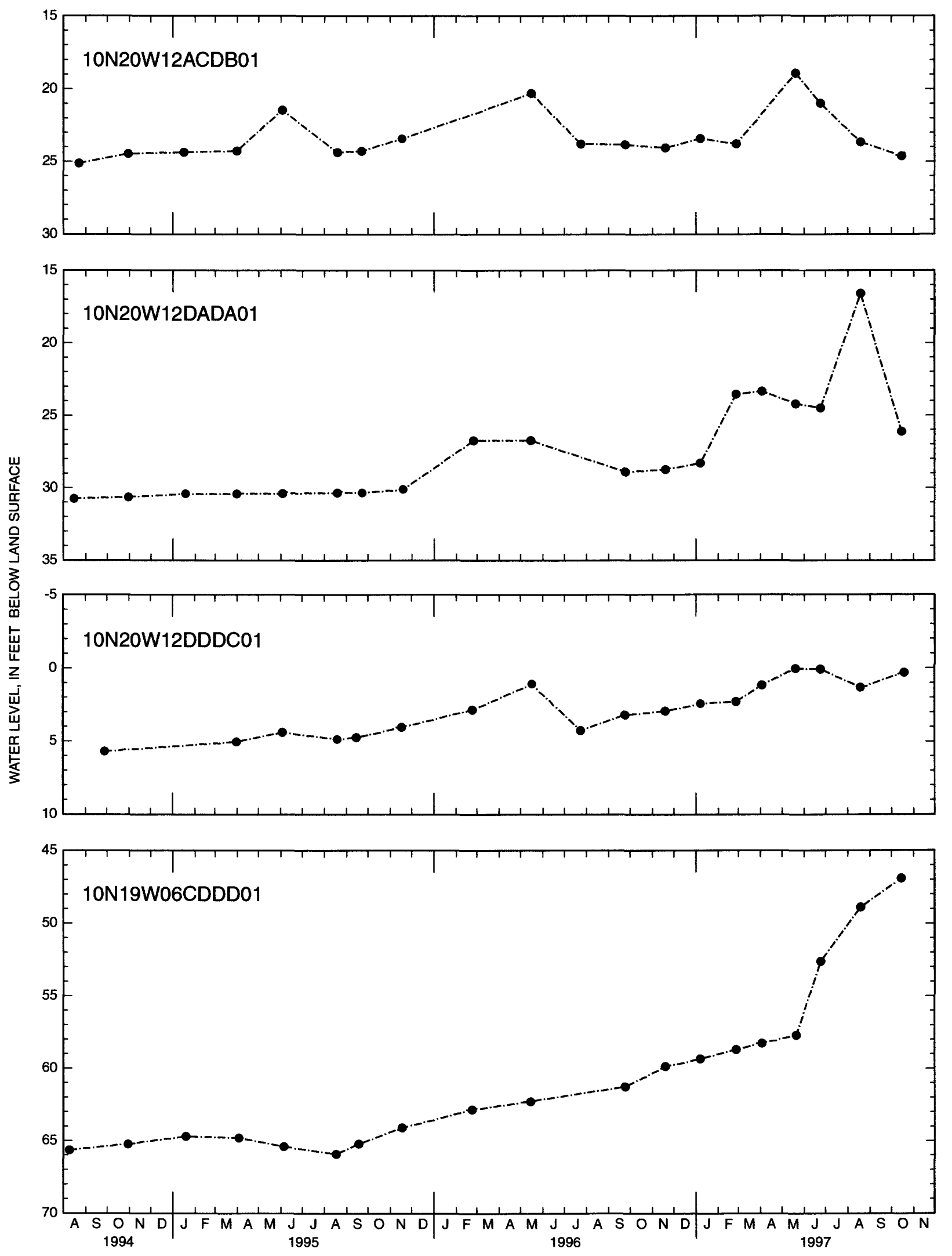

Figure 21. Hydrographs of water levels in wells of the monitoring network. 

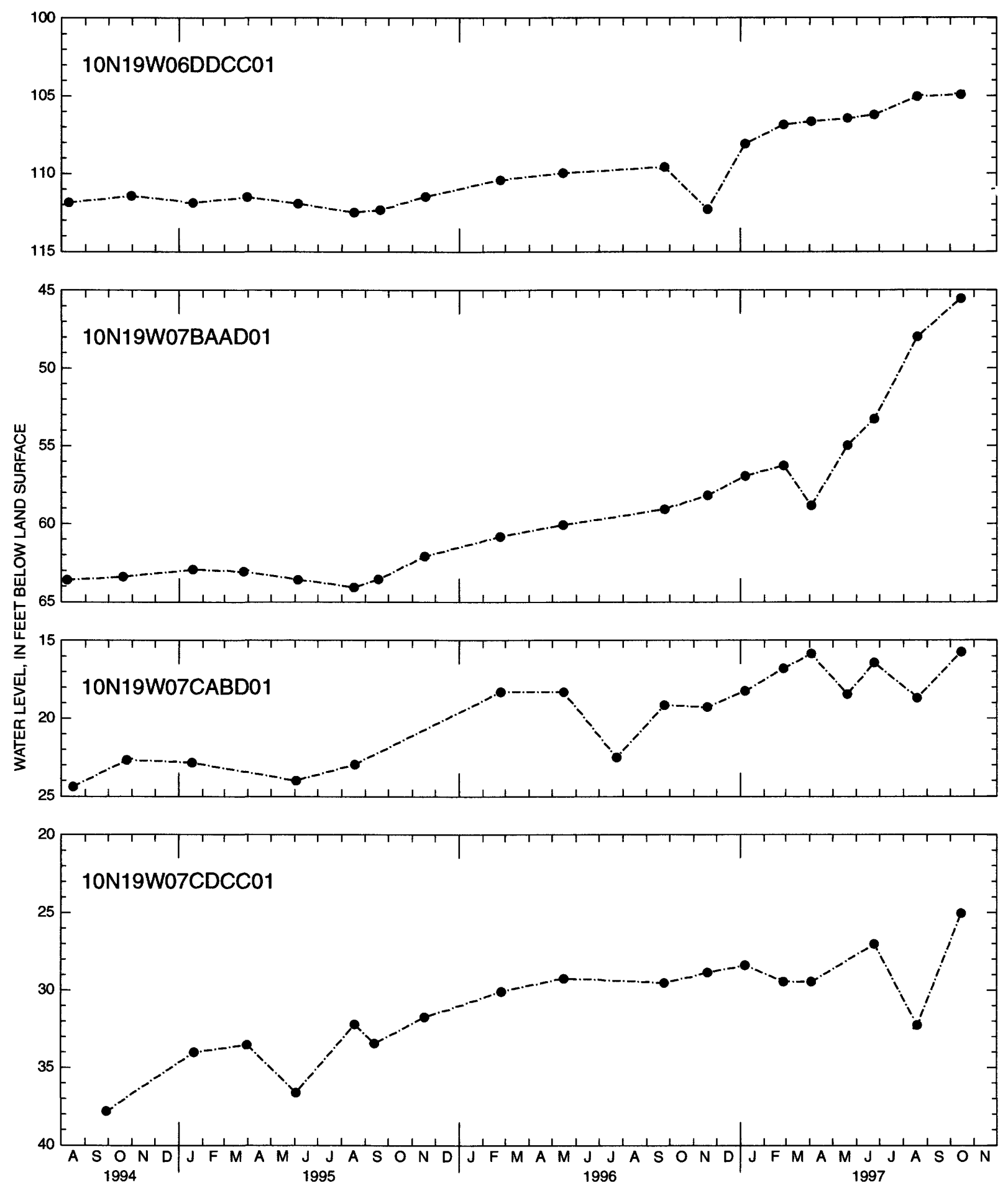

Figure 21. Hydrographs of water levels in wells of the monitoring network (Continued) 

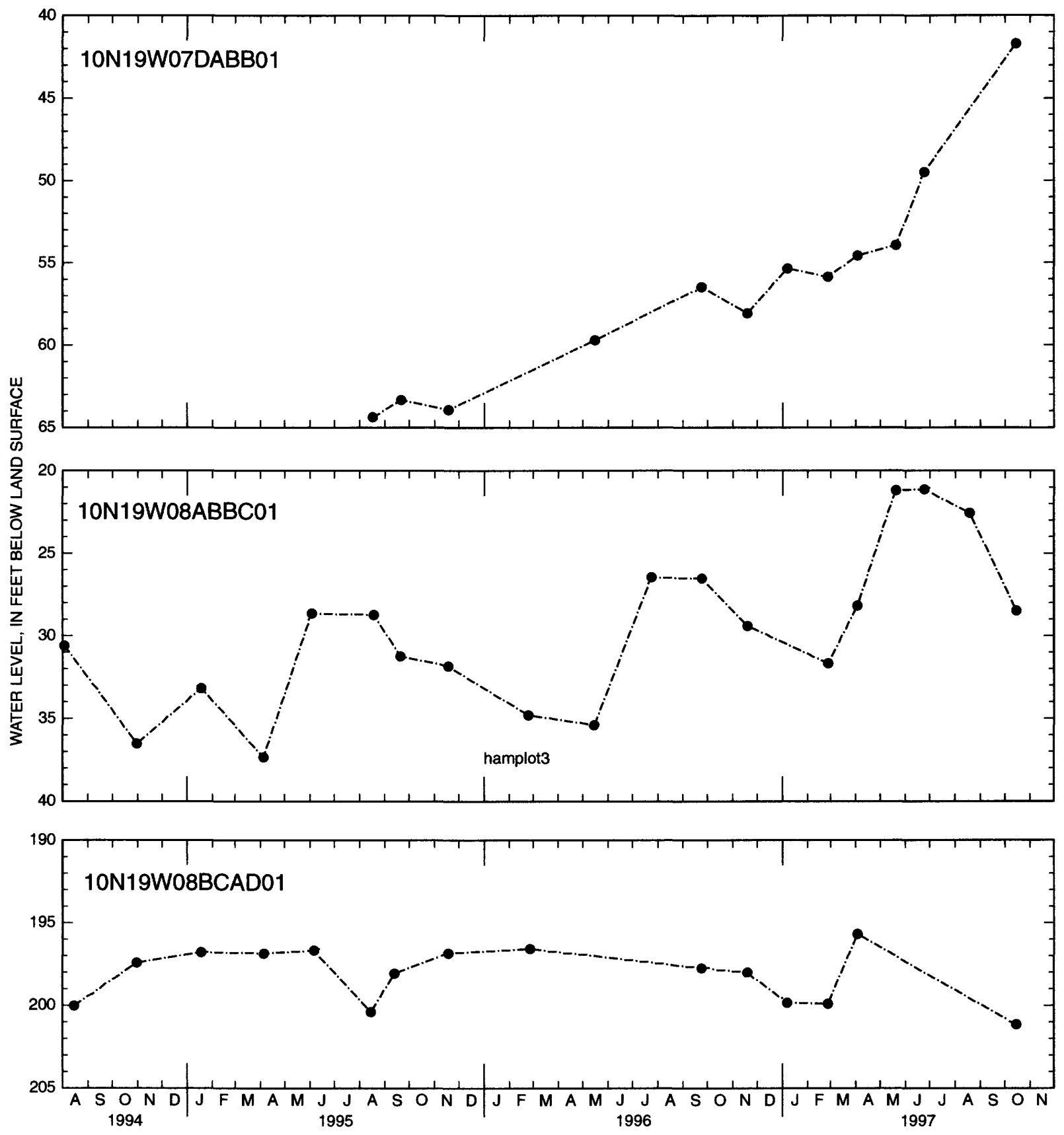

Figure 21. Hydrographs of water levels in wells of the monitoring network (Continued) 


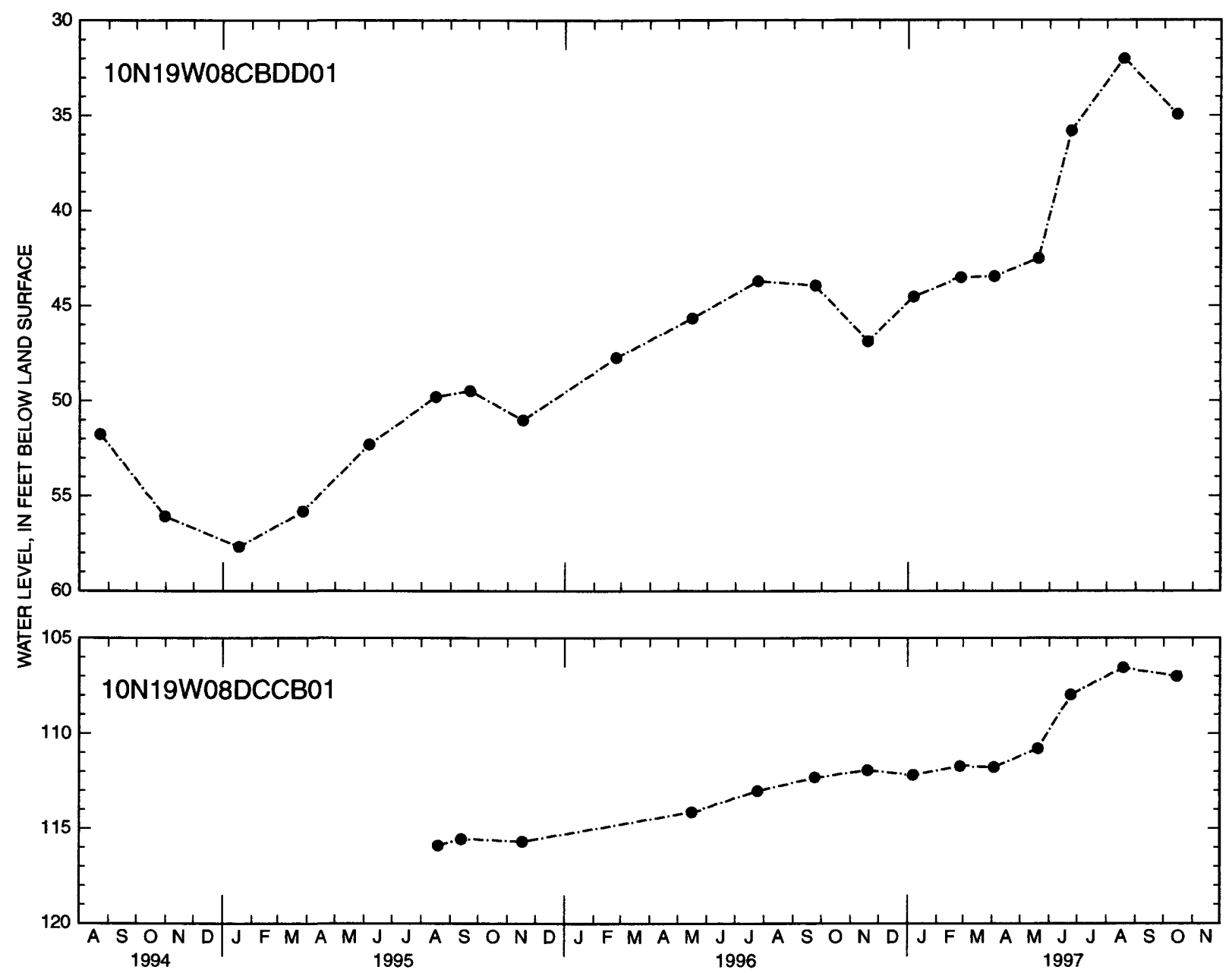

Figure 21. Hydrographs of water levels in wells of the monitoring network (Continued) 

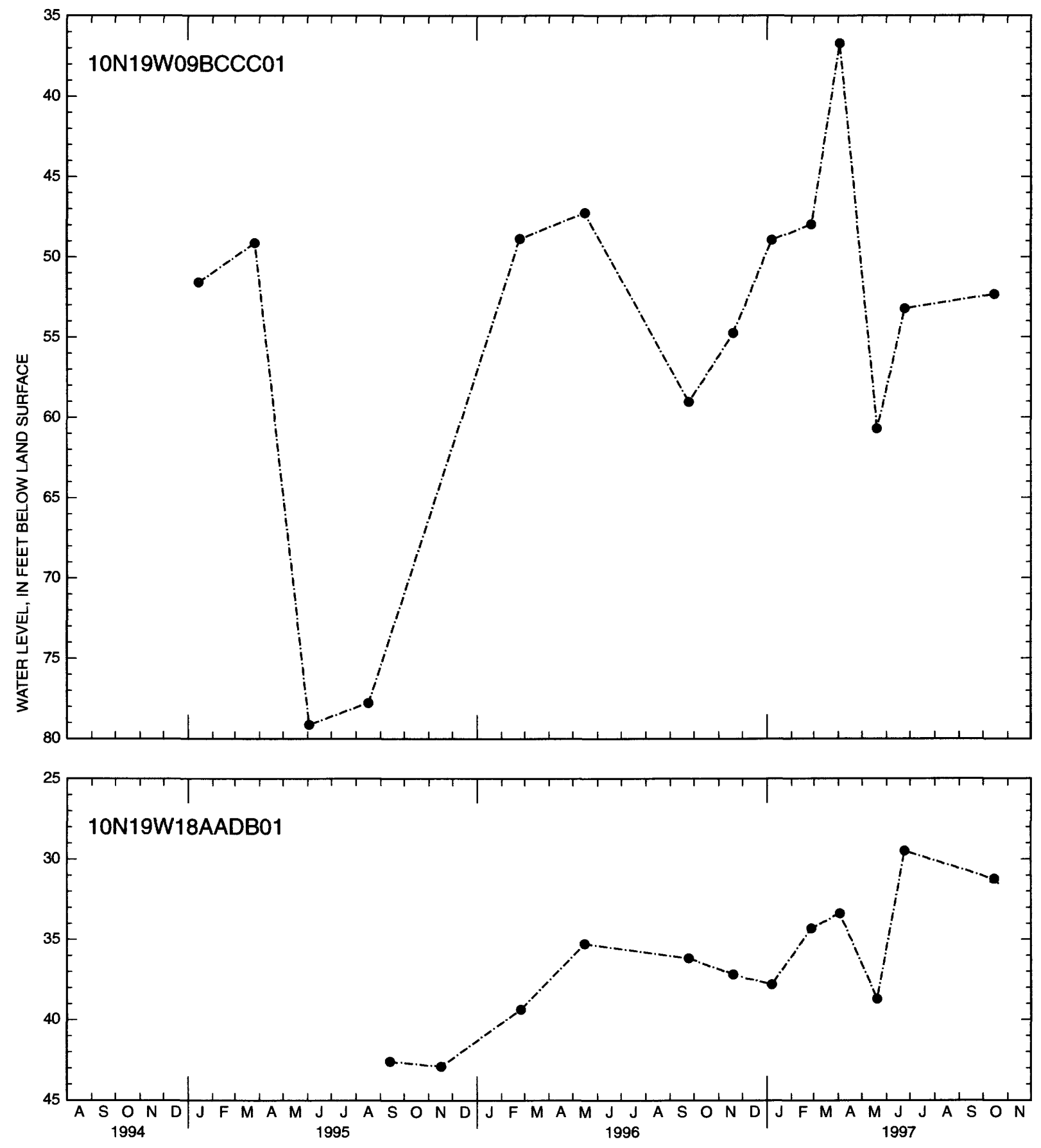

Figure 21. Hydrographs of water levels in wells of the monitoring network (Continued) 

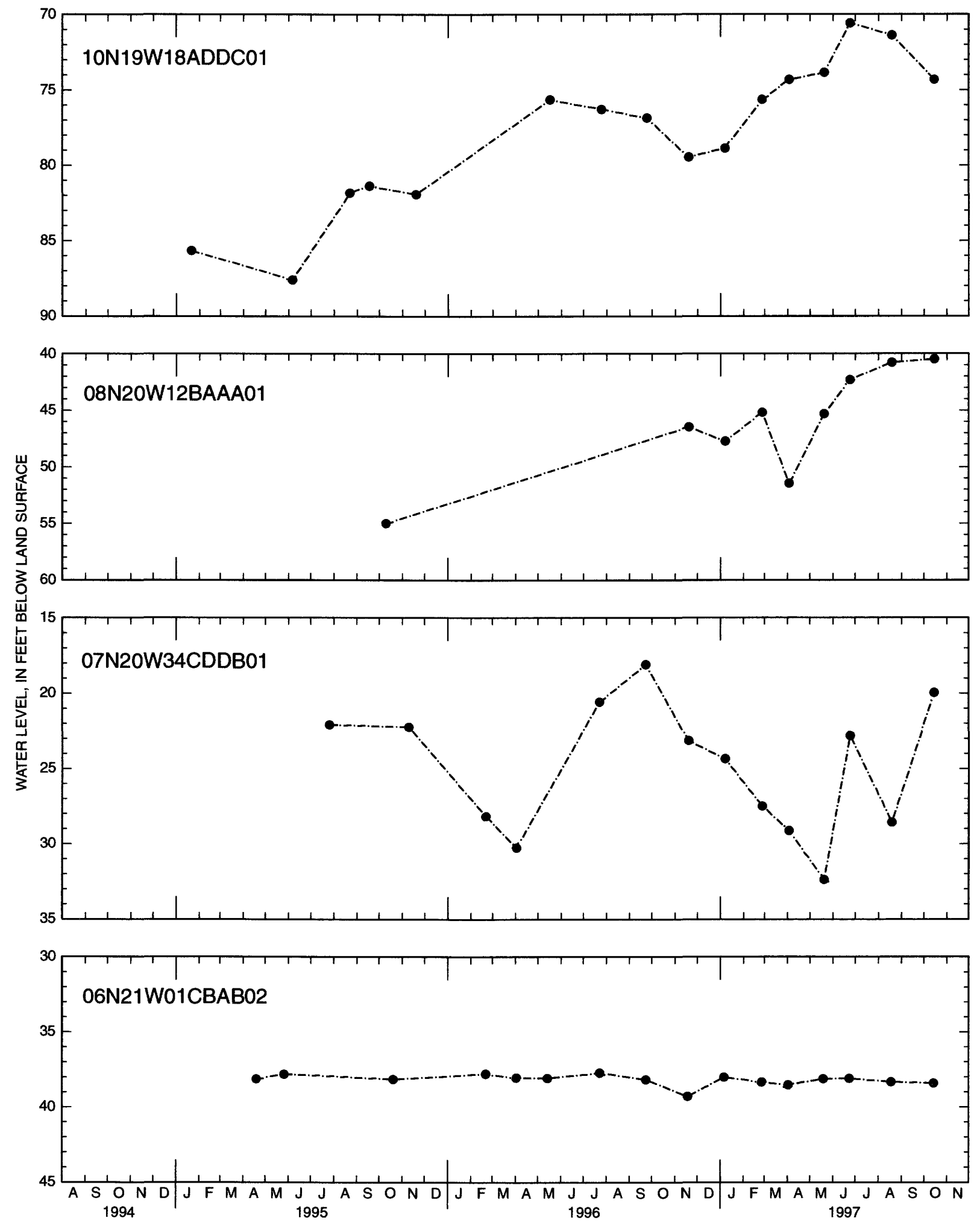

Figure 21. Hydrographs of water levels in wells of the monitoring network (Continued) 

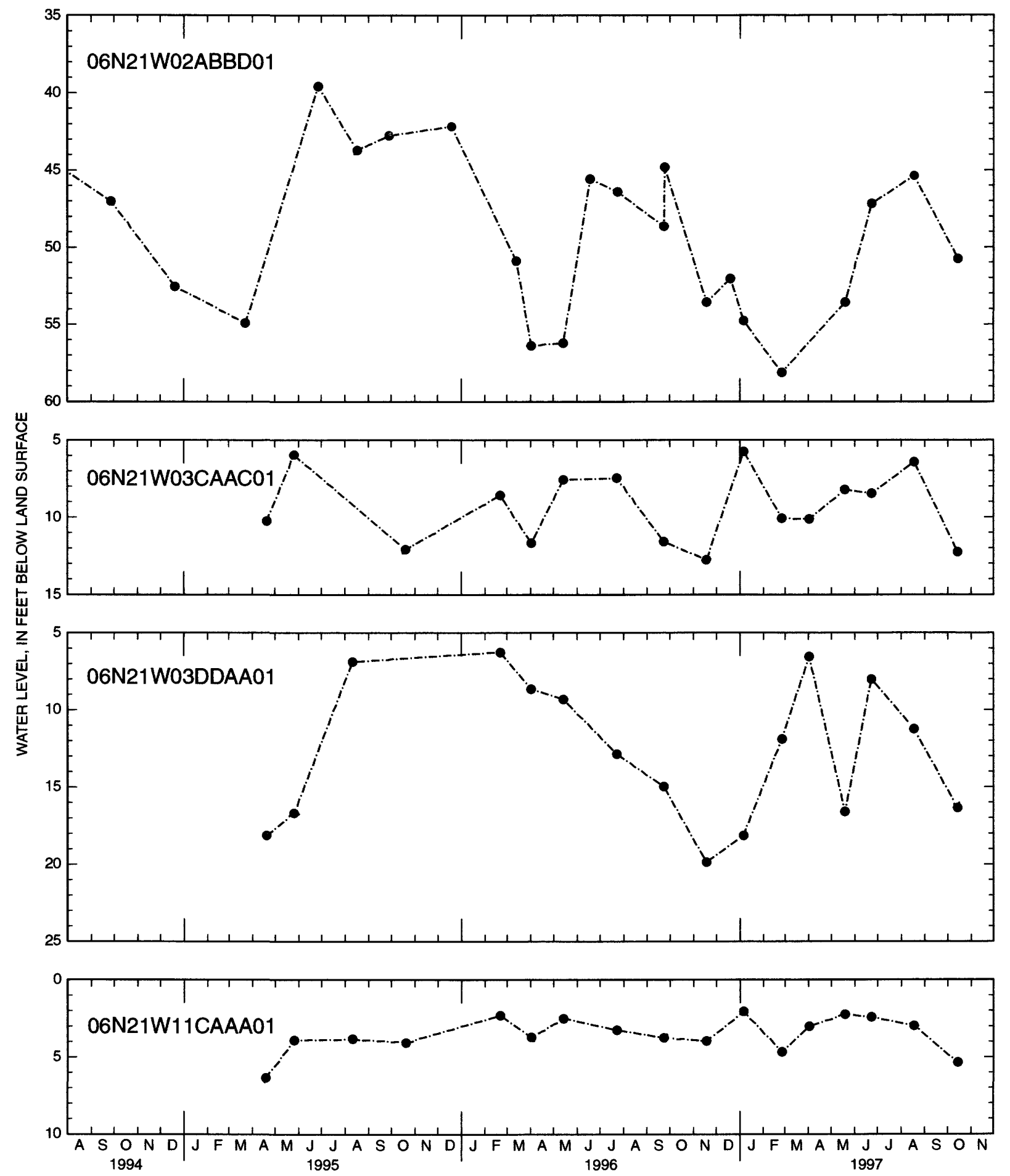

Figure 21. Hydrographs of water levels in wells of the monitoring network (Continued) 

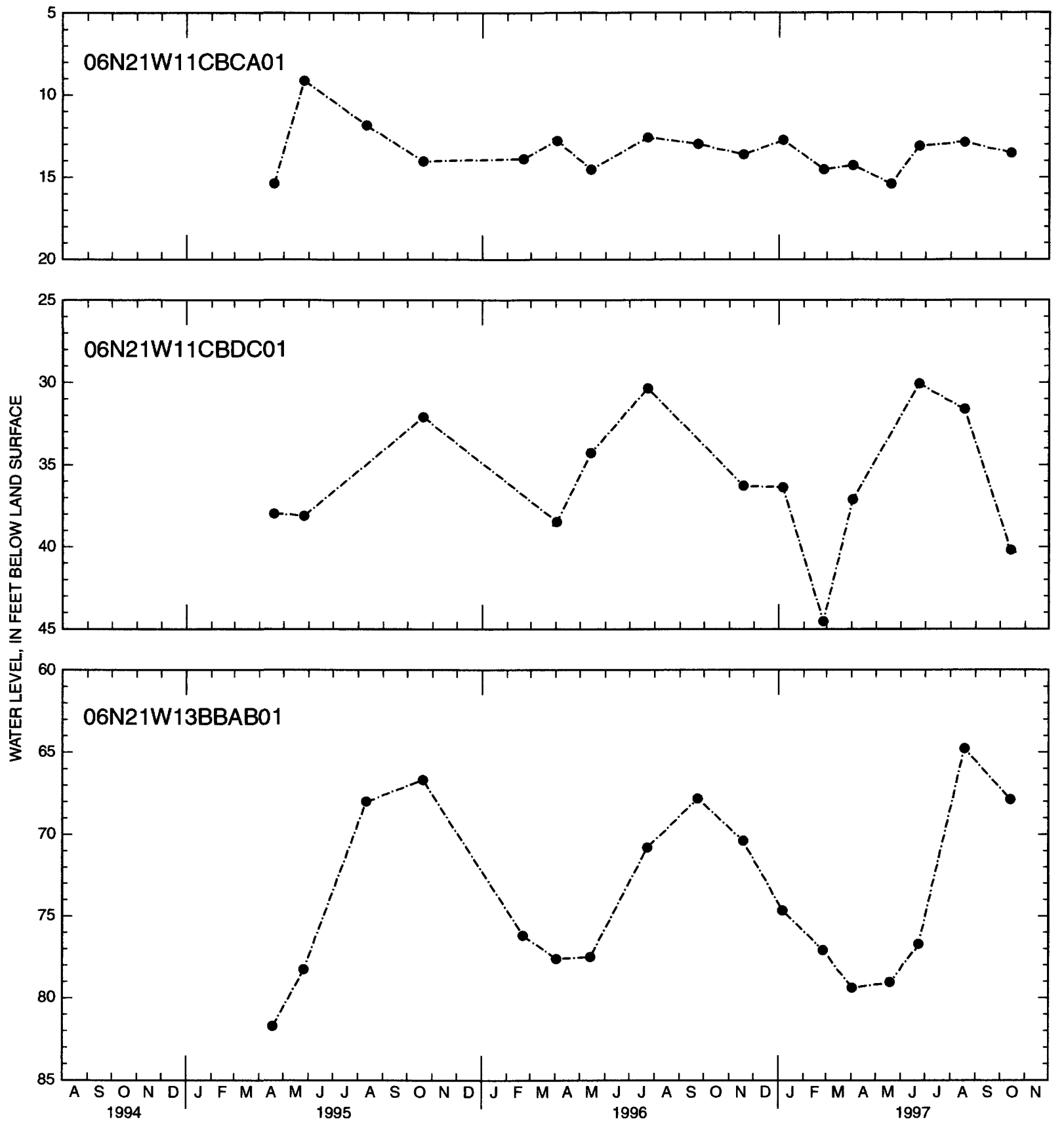

Figure 21. Hydrographs of water levels in wells of the monitoring network (Continued) 

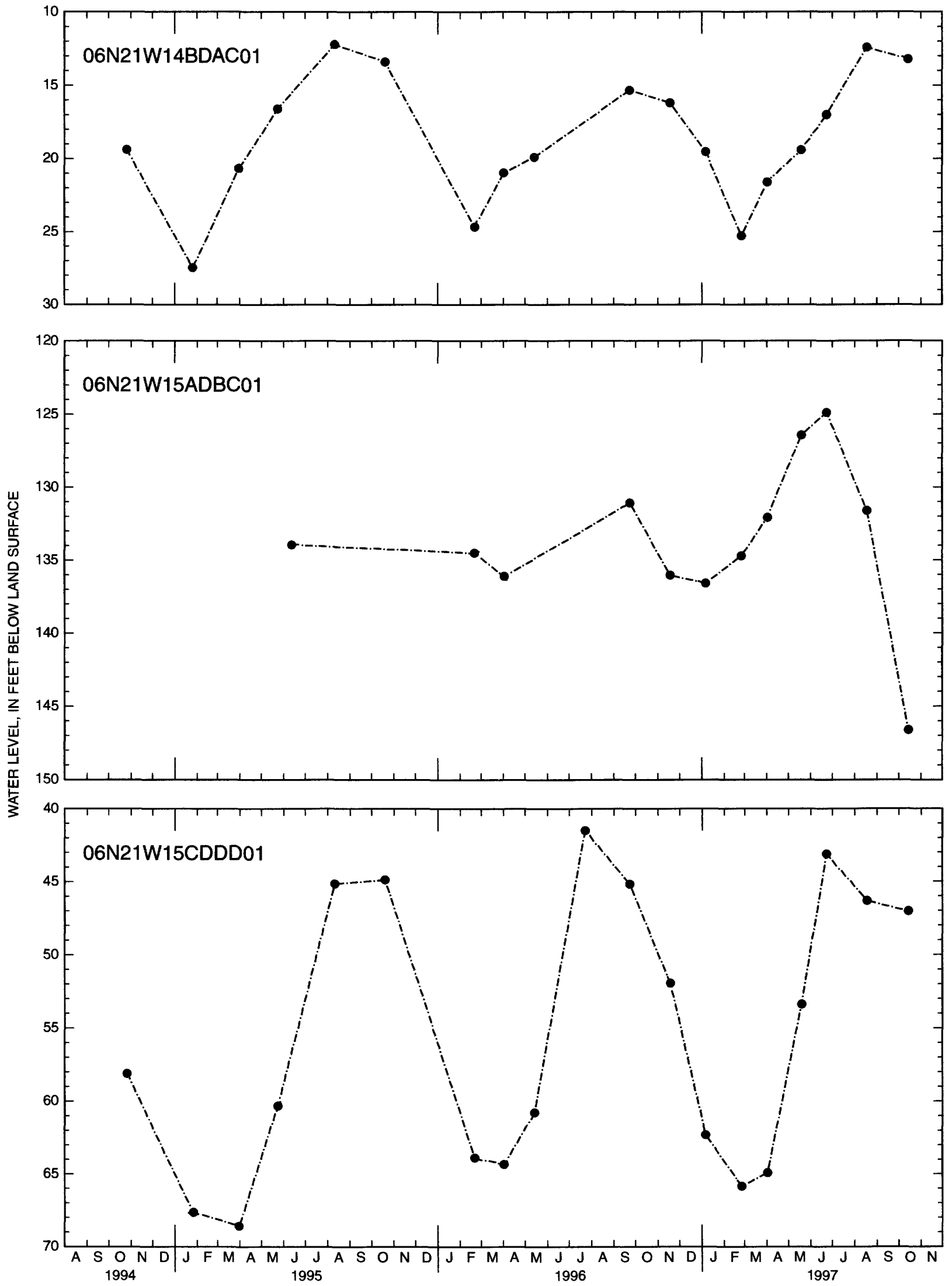

Figure 21. Hydrograph of water levels in wells of the monitoring network (Continued)

FIGURE 21

77 

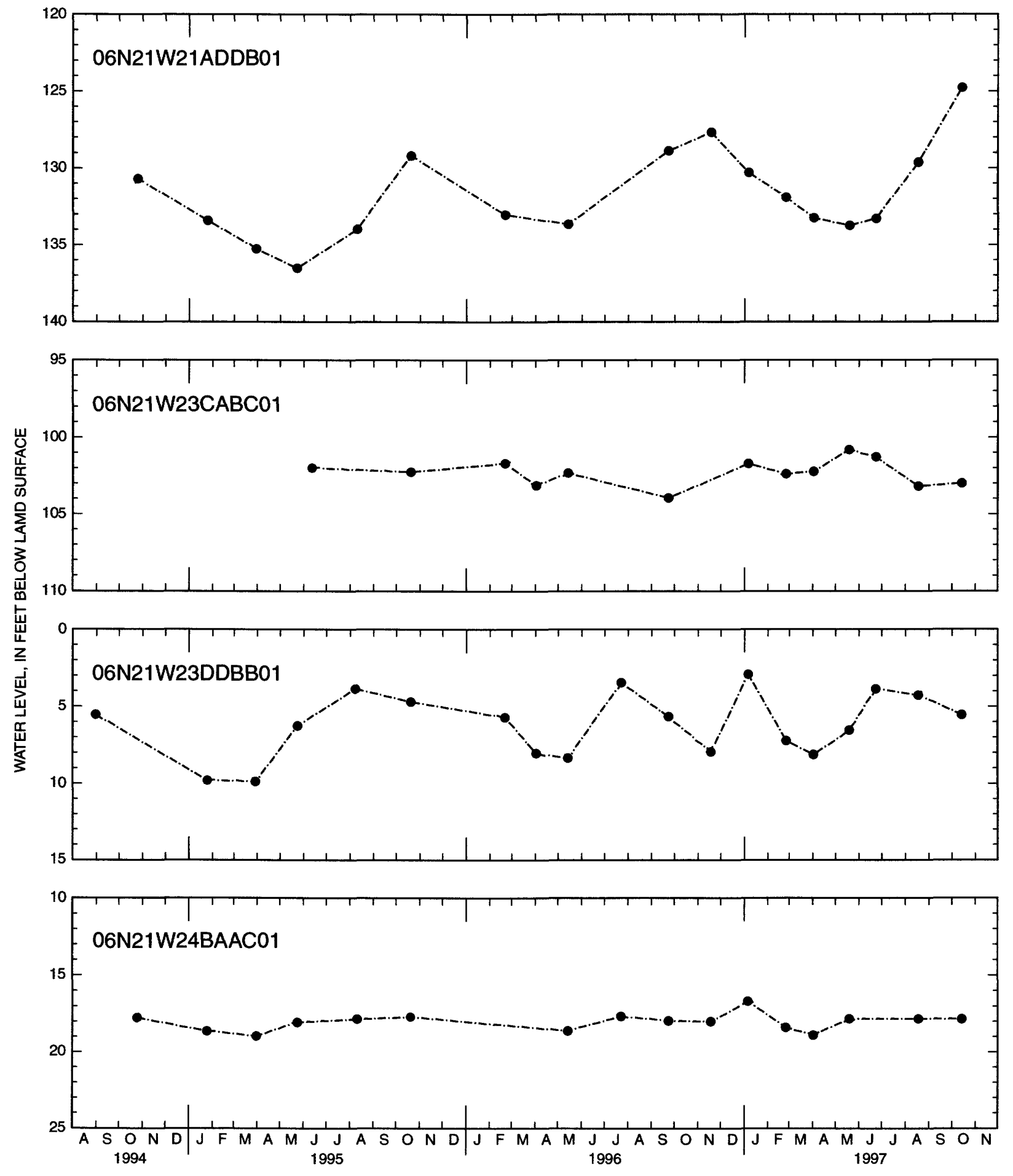

Figure 21. Hydrographs of water levels in wells of the monitoring network (Continued) 

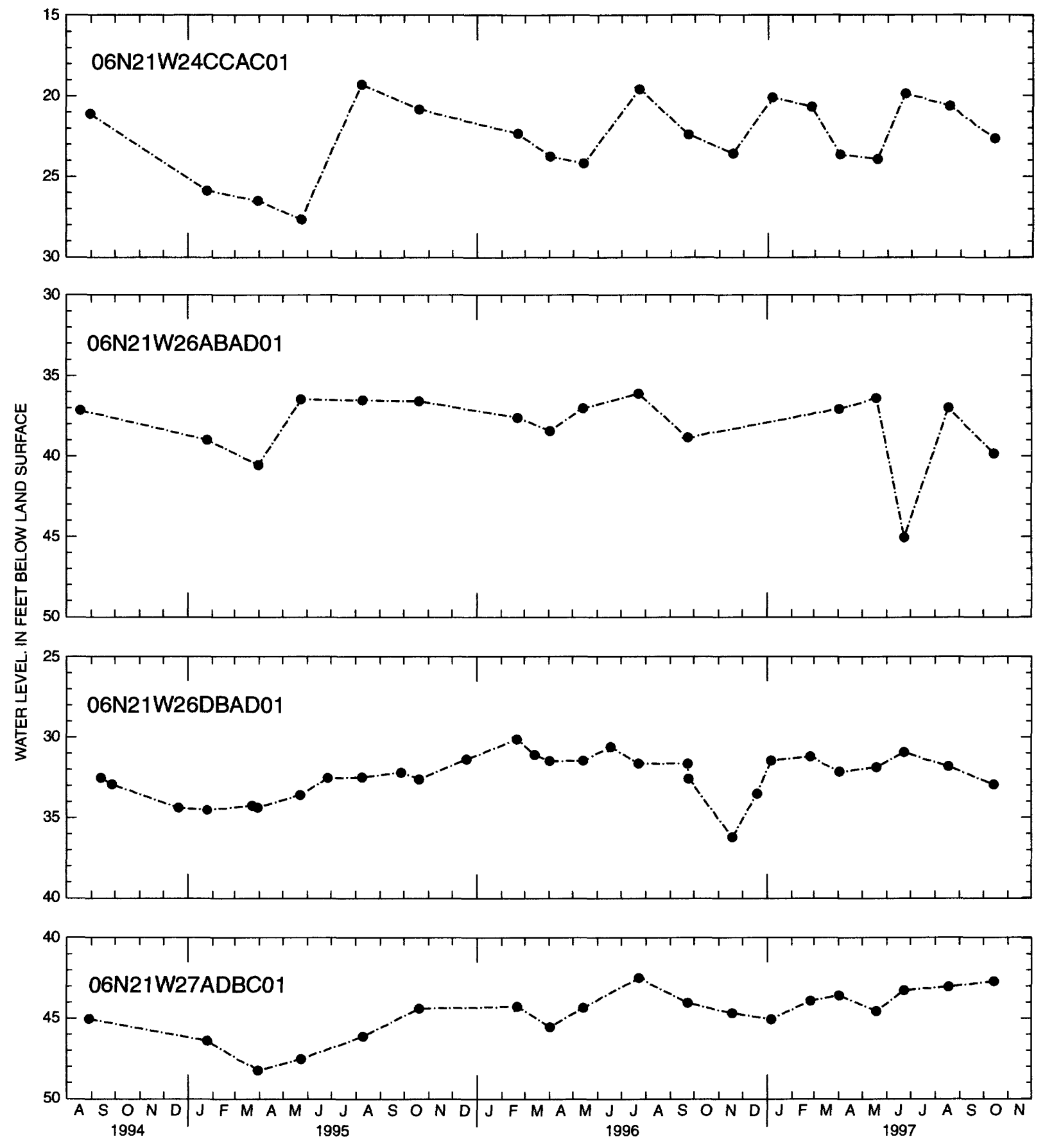

Figure 21. Hydrographs of water levels in wells of the monitoring network (Continued) 

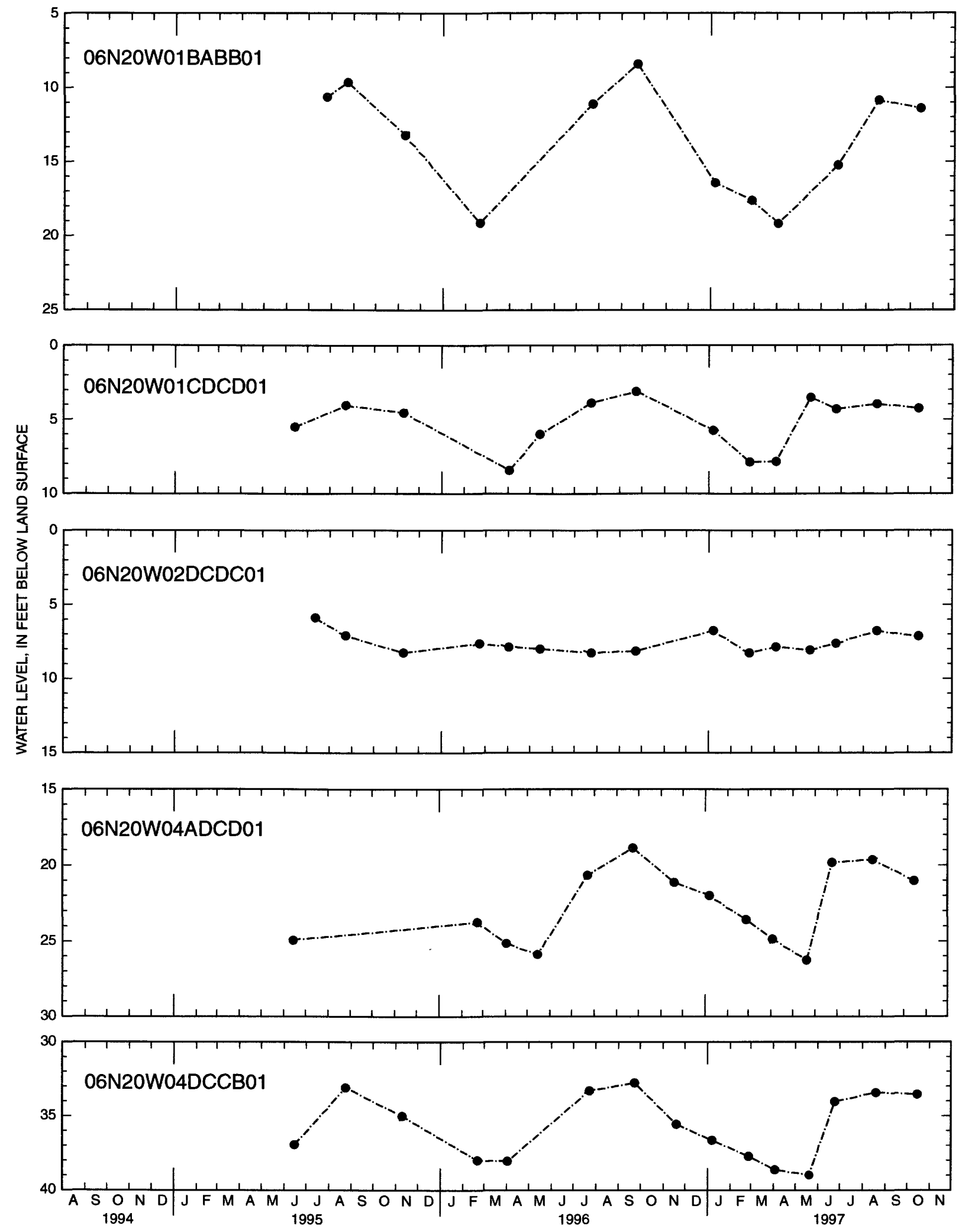

Figure 21. Hydrographs of water levels in wells of the monitoring network (Continued) 

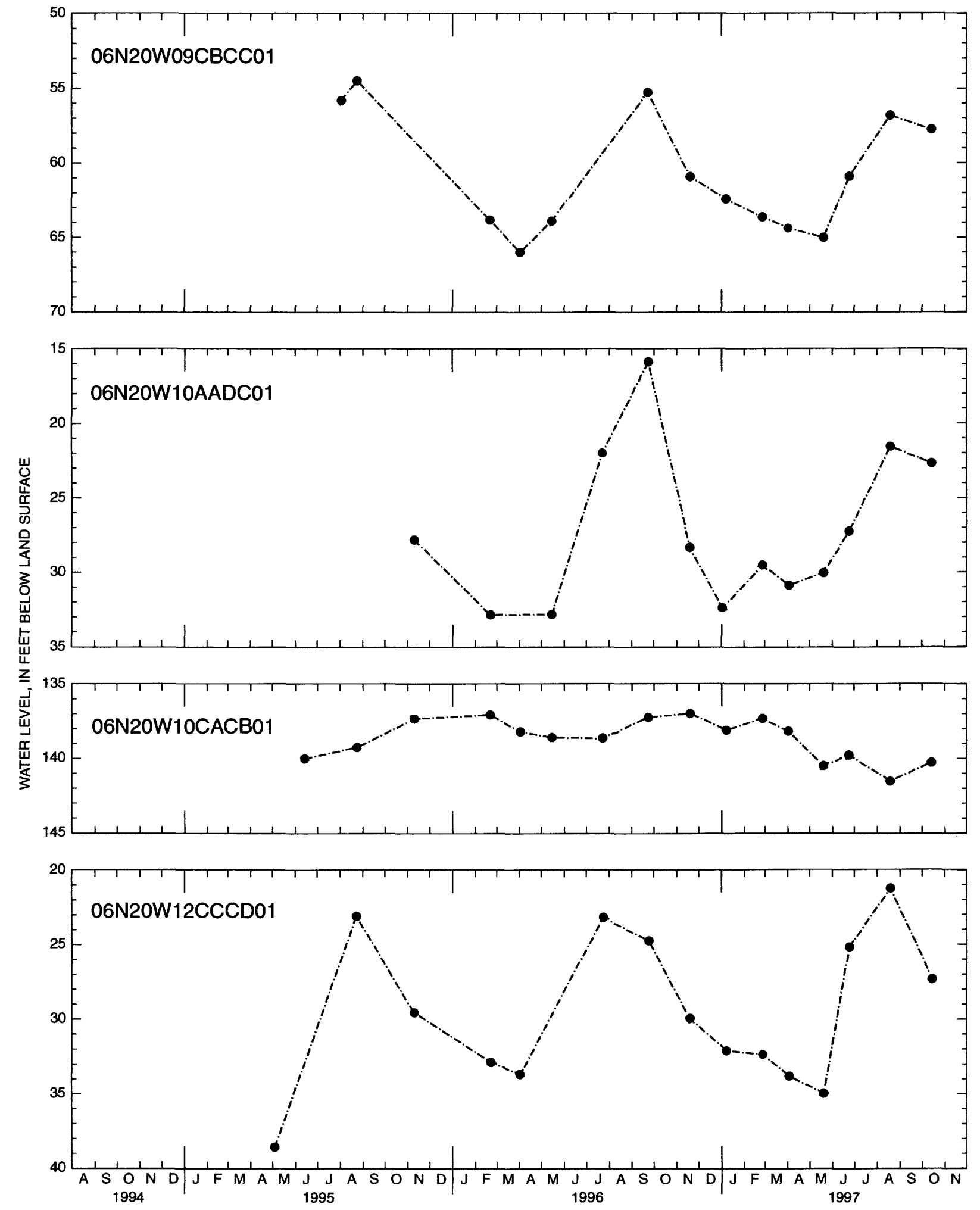

Figure 21. Hydrographs of water levels in wells of the monitoring network (Continued) 

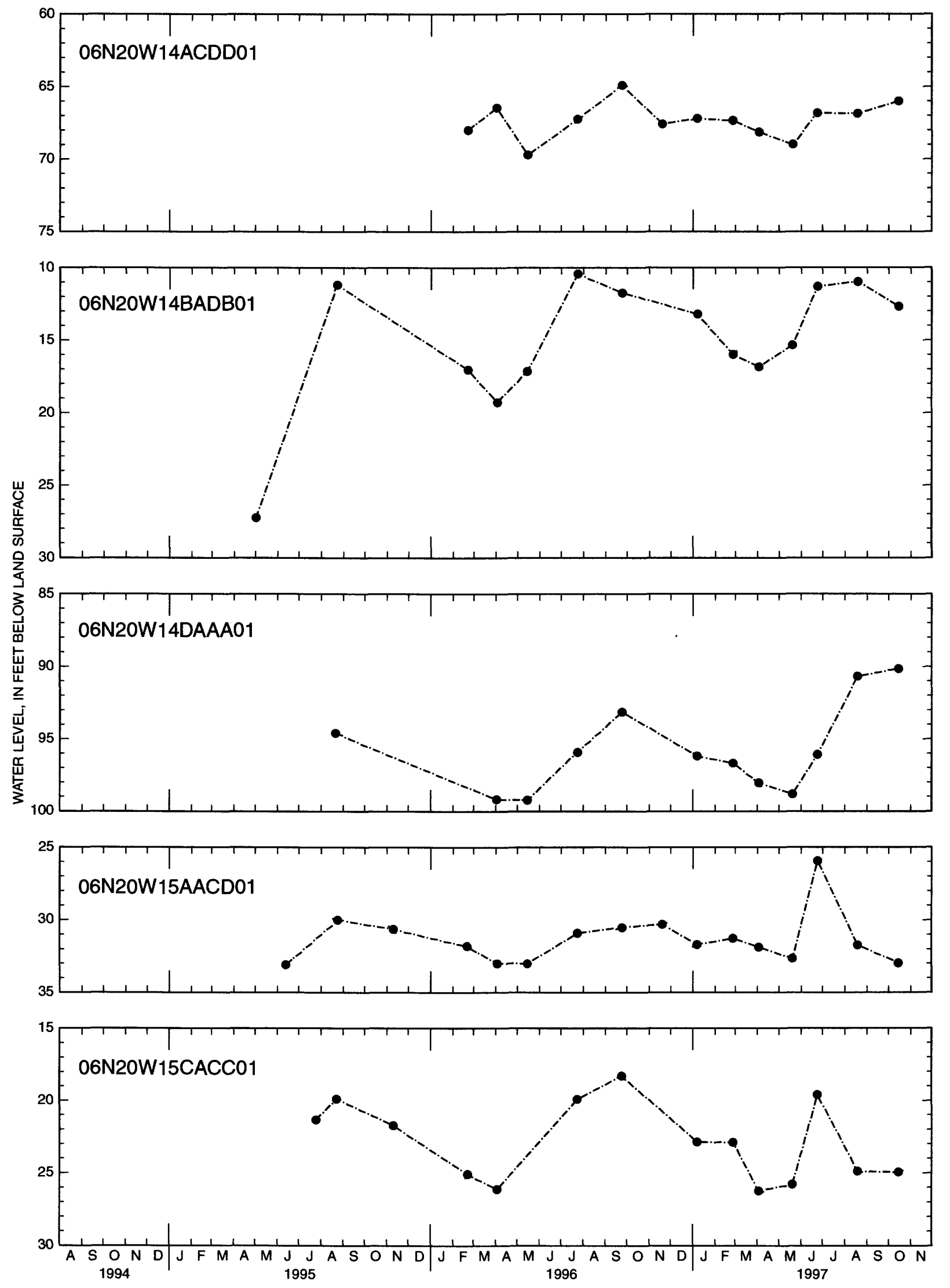

Figure 21. Hydrographs of water levels in wells of the monitoring network (Continued) 

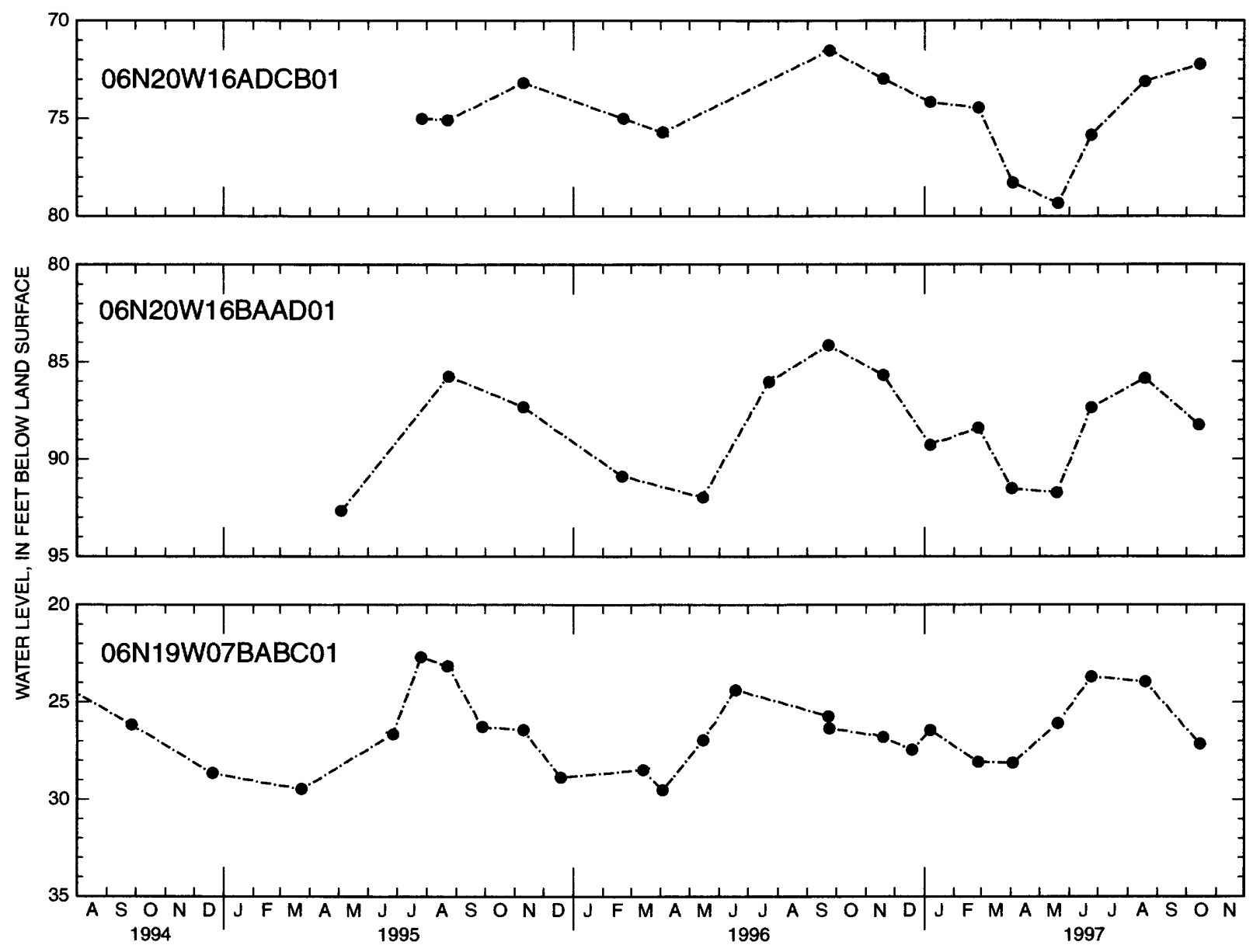

Figure 21. Hydrographs of water levels in wells of the monitoring network (Continued) 
Table 6. Physical properties and major-ion concentrations for water from wells

[Location number--numbering system described in text. Constituents are dissolved, except as indicated. Collecting agency: MBMG, Montana Bureau of Mines and Geology, Butte, Mont.; USGS, U.S. Geological Survey, Helena, Mont. Analyzing agency: MBMG, Montana Bureau of Mines and Geology, Analytical Division, Butte, Mont.; UM, University of Montana, Missoula, Mont.; NWQL, USGS National Water Quality Laboratory, Arvada, Colo. Abbreviations: $\mu \mathrm{S} / \mathrm{cm}$, microsiemens per centimeter at 25 degrees Celsius; ${ }^{\circ} \mathrm{C}$, degrees Celsius; $\mathrm{mg} / \mathrm{L}$, milligrams per liter. Symbols: <, less than minimum reporting level; --, no data]

\begin{tabular}{|c|c|c|c|c|c|c|c|c|c|c|c|}
\hline $\begin{array}{l}\text { Location } \\
\text { number }\end{array}$ & Date & $\begin{array}{c}\text { Specific } \\
\text { conduct- } \\
\text { ance, } \\
\text { field } \\
(\mu \mathrm{S} / \mathrm{cm})\end{array}$ & $\begin{array}{c}\text { pH, } \\
\text { field } \\
\text { (stand- } \\
\text { ard } \\
\text { units) }\end{array}$ & $\begin{array}{c}\text { Temper- } \\
\text { ature, } \\
\text { water } \\
\left({ }^{\circ} \mathrm{C}\right)\end{array}$ & $\begin{array}{l}\text { Oxygen, } \\
\text { dis- } \\
\text { solved, } \\
\text { field } \\
(\mathrm{mg} / \mathrm{L})\end{array}$ & $\begin{array}{c}\begin{array}{c}\text { Cal- } \\
\text { cium }\end{array} \\
\text { (mg/L as } \\
\text { Ca) }\end{array}$ & $\begin{array}{l}\text { Magne- } \\
\text { sium } \\
\text { (mg/L as } \\
\text { Mg) }\end{array}$ & $\begin{array}{l}\text { Sodium } \\
\text { (mg/L as } \\
\mathrm{Na})\end{array}$ & $\begin{array}{l}\text { Potas- } \\
\text { sium } \\
\text { (mg/L as } \\
\text { K) }\end{array}$ & $\begin{array}{c}\text { Bicar- } \\
\text { bonate } \\
(\mathrm{mg} / \mathrm{L} \text { as } \\
\left.\mathrm{HCO}_{3}\right)\end{array}$ & $\begin{array}{c}\text { Carbon- } \\
\text { ate }^{1} \\
(\mathrm{mg} / \mathrm{L} \text { as } \\
\left.\mathrm{CO}_{3}\right)\end{array}$ \\
\hline $10 \mathrm{~N} 20 \mathrm{~W} 02 \mathrm{ABBC} 01$ & $08-03-94$ & 138 & - & 14.5 & -- & -- & -- & -- & $\overline{--}$ & - & -- \\
\hline 10N20W10ACBC01 & $06-23-80$ & 97.0 & - & 11.5 & -- & 8.5 & 2.0 & 7.3 & 1.5 & -- & -- \\
\hline \multirow[t]{2}{*}{ 10N20W10CBBD01 } & $03-10-94$ & 46.0 & 6.5 & 6.0 & -- & 5.1 & 1.6 & 2.5 & .60 & - & - \\
\hline & $10-26-95$ & 63.0 & 6.6 & 11.0 & - & -- & -- & -- & -- & - & -- \\
\hline \multirow[t]{2}{*}{ 10N20W11CDCD01 } & $03-10-94$ & 106 & 6.6 & 11.5 & -- & 9.1 & 2.6 & 9.0 & 1.6 & -- & -- \\
\hline & $12-14-95$ & 143 & 7.2 & 14.0 & - & -- & -- & - & -- & -- & -- \\
\hline 10N20W12ACDB01 & $08-24-94$ & 264 & - & 13.5 & - & -- & - & -- & -- & - & -- \\
\hline \multirow[t]{2}{*}{ 10N20W12ADCB01 } & $08-28-95$ & 354 & -- & 12.5 & -- & - & -- & - & -- & -- & -- \\
\hline & $09-13-95$ & 344 & 7.2 & 12.5 & 8.6 & 48 & 12 & 8.6 & 2.4 & 210 & 0 \\
\hline 10N20W12ADDC01 & $08-15-94$ & 338 & -- & 13.0 & -- & -- & -- & -- & - & -- & -. \\
\hline 10N20W12DAAA01 & $08-15-94$ & 286 & - & 13.5 & -- & -- & -- & -- & -- & - & -- \\
\hline 10N20W12DABD01 & $08-28-95$ & 283 & - & 14.0 & -- & - & - & -- & - & -- & -- \\
\hline \multirow[t]{10}{*}{ 10N20W12DADA01 } & $08-15-94$ & 292 & -- & 13.0 & -- & -- & -- & -- & - & -- & - \\
\hline & $11-19-96$ & 294 & - & 13.0 & -- & -- & -- & -- & -- & -- & -- \\
\hline & $01-07-97$ & 303 & -- & 11.5 & -- & -- & -- & -- & -- & -- & - \\
\hline & $02-26-97$ & 304 & - & 11.5 & -- & -- & -- & -- & - & -- & -- \\
\hline & 04-03-97 & 305 & -- & 11.9 & -- & -- & - & -- & -- & -- & -- \\
\hline & $05-19-97$ & 287 & -- & 13.5 & -- & -- & - & -- & -- & - & -- \\
\hline & $06-24-97$ & 292 & -- & 12.6 & - & -- & - & - & - & -- & - \\
\hline & $06-24-97^{2}$ & 292 & -- & 12.6 & -- & -- & - & - & - & -- & -- \\
\hline & $08-19-97$ & 298 & -- & 12.0 & -- & -- & -- & -- & -- & -- & -- \\
\hline & $10-15-97$ & - & -- & -- & -- & -- & -- & -- & -- & -- & -- \\
\hline \multirow[t]{2}{*}{ 10N20W12DDDC01 } & $09-27-94$ & 216 & - & 13.5 & -- & - & - & -- & - & -- & -- \\
\hline & $09-15-95$ & 209 & 7.1 & 13.0 & 8.5 & 28 & 6.8 & 5.7 & 2.5 & 124 & 0 \\
\hline 10N20W13BBA 01 & $05-12-80$ & -- & -- & -- & -- & 8.5 & 1.9 & 4.2 & 1.1 & -- & -- \\
\hline 10N19W05CCCC01 & $08-29-95$ & 297 & -- & 11.0 & -- &.- & -- & -- & - & -- & -- \\
\hline 10N19W05CCCD01 & $08-29-95$ & 443 & - & 16.0 & -- & -- & - & -. & -- & -- & -- \\
\hline \multirow[t]{3}{*}{ 10N19W05CDCC01 } & $08-10-94$ & 340 & -- & 11.5 & -- & -- & -- & -- & -- & - & -- \\
\hline & $08-10-94^{2}$ & 340 & -- & 11.5 & -- & -- & -- & -- & -- & - & -- \\
\hline & $08-15-94$ & - & -- & - & -- & -- & -- & -- & -- & -- & - \\
\hline \multirow[t]{3}{*}{ 10N19W05DCDD01 } & $08-03-94$ & 504 & - & 10.5 & - & -- & -- & -- & -- & -- & - \\
\hline & $06-08-95$ & -- & -- & -- & -- & -- & -- & -- & - & -- & - \\
\hline & $09-12-95$ & 572 & 7.2 & 11.5 & 8.8 & 70 & 20 & 24 & 4.2 & 322 & 0 \\
\hline \multirow[t]{2}{*}{ 10N19W06CDCB01 } & $09-27-94$ & 306 & -- & 13.5 & -- & -- & -- & -- & - & - & - \\
\hline & $06-08-95$ & - & - & -- & -- & - & -- & -- & -- & - & - \\
\hline 10N19W06CDDA01 & $08-28-95$ & 421 & - & 12.5 & - & -- & -- & -- & -- & -- & -- \\
\hline 10N19W06CDDD01 & $08-10-94$ & 404 & 3.0 & 12.0 & -- & -- & -- & -- & -- & - & -- \\
\hline \multirow[t]{2}{*}{ 10N19W06DCCC01 } & $08-10-94$ & 409 & - & 11.0 & - & -- & -- & -- & -- & -- & -- \\
\hline & $08-10-94^{2}$ & 409 & -- & 11.0 & -- & -- & -- & -- & -- & -- & - \\
\hline \multirow[t]{2}{*}{ 10N19W06DCDA01 } & $08-10-94$ & 419 & -- & 11.5 & - & -- & -- & -- & - & -- & -- \\
\hline & $09-12-95$ & 400 & 7.2 & 10.5 & 7.6 & 49 & 13 & 16 & 4.0 & 235 & 0 \\
\hline 10N19W06DDCC01 & 08-15-94 & 277 & -- & 12.5 & - & -- & - & -- & -- & -- & - \\
\hline \multirow[t]{4}{*}{ 10N19W07ADBC01 } & $08-10-94$ & 359 & - & 12.5 & -- & - & -- & -- & - & -- & - \\
\hline & $08-15-94$ & - & -- & -- & - & -- & - & -- & - & -- & -- \\
\hline & $09-13-95$ & 375 & 7.4 & 11.5 & 9.4 & 53 & 13 & 6.2 & 2.6 & 203 & 0 \\
\hline & $09-13-95^{2}$ & 375 & 7.4 & 11.5 & 9.4 & 53 & 13 & 6.1 & 2.4 & 203 & 0 \\
\hline
\end{tabular}




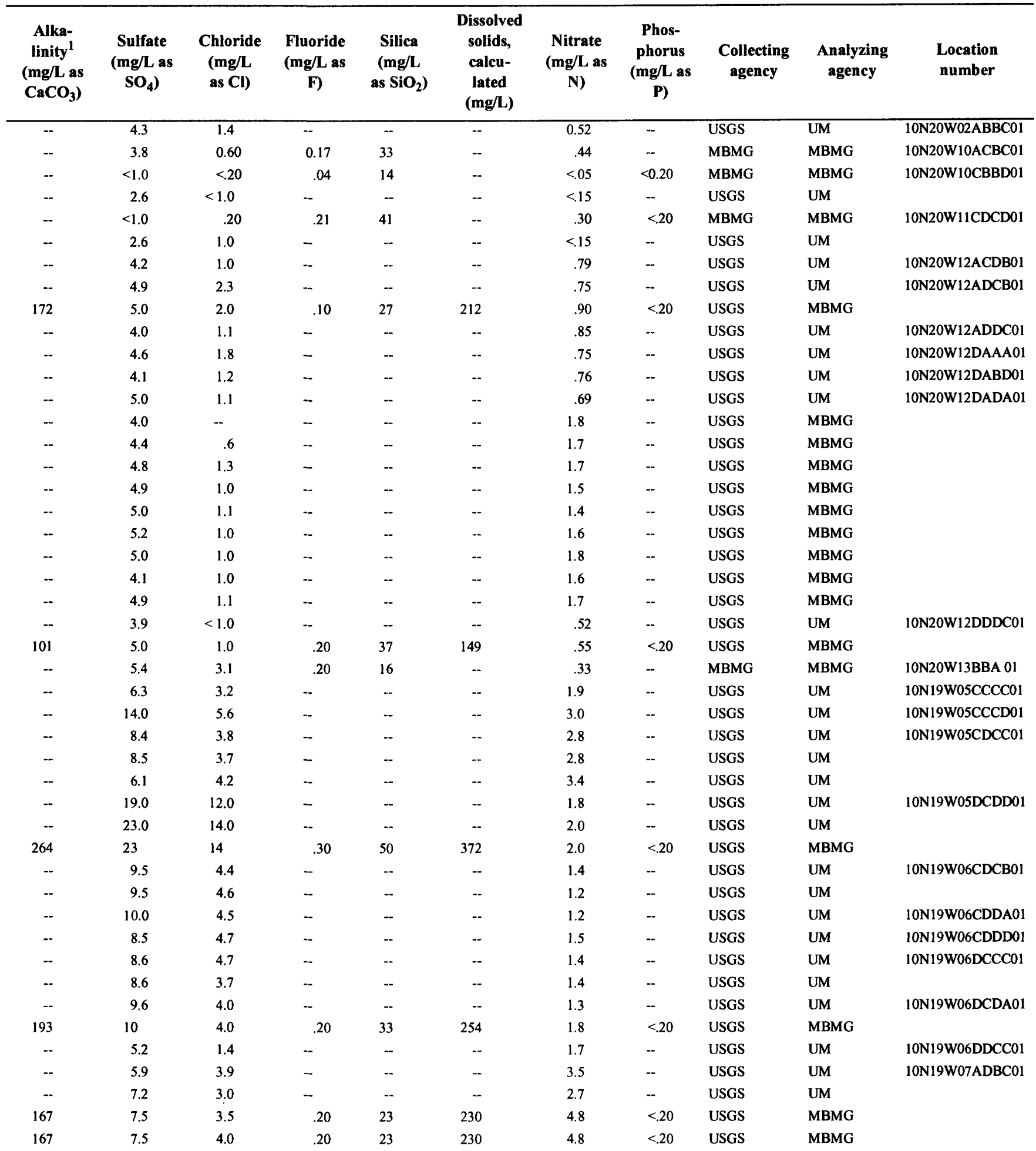


Table 6. Physical properties and major-ion concentrations for water from wells (Continued)

\begin{tabular}{|c|c|c|c|c|c|c|c|c|c|c|c|}
\hline $\begin{array}{l}\text { Location } \\
\text { number }\end{array}$ & Date & $\begin{array}{c}\text { Specific } \\
\text { conduct- } \\
\text { ance, } \\
\text { field } \\
(\mu \mathrm{S} / \mathrm{cm})\end{array}$ & $\begin{array}{c}\text { pH, } \\
\text { field } \\
\text { (stand- } \\
\text { ard } \\
\text { units) }\end{array}$ & $\begin{array}{c}\text { Temper- } \\
\text { ature, } \\
\text { water } \\
\left({ }^{\circ} \mathrm{C}\right)\end{array}$ & $\begin{array}{l}\text { Oxygen, } \\
\text { dis- } \\
\text { solved, } \\
\text { field } \\
\text { (mg/L) }\end{array}$ & $\begin{array}{c}\begin{array}{c}\text { Cal- } \\
\text { cium }\end{array} \\
\text { (mg/L as } \\
\text { Ca) }\end{array}$ & $\begin{array}{l}\text { Magne- } \\
\text { sium } \\
\text { (mg/L as } \\
\text { Mg) }\end{array}$ & $\begin{array}{c}\text { Sodium } \\
\text { (mg/L as } \\
\text { Na) }\end{array}$ & $\begin{array}{l}\text { Potas- } \\
\text { sium } \\
(\mathrm{mg} / \mathrm{L} \text { as } \\
\mathrm{K})\end{array}$ & $\begin{array}{c}\text { Bicar- } \\
\text { bonate }^{1} \\
(\mathrm{mg} / \mathrm{L} \text { as } \\
\left.\mathrm{HCO}_{3}\right)\end{array}$ & $\begin{array}{c}\text { Carbon- } \\
\text { ate }{ }^{1} \\
(\mathrm{mg} / \mathrm{L} \text { as } \\
\left.\mathrm{CO}_{3}\right)\end{array}$ \\
\hline \multirow[t]{10}{*}{ 10N19W07BAAD01 } & $08-10-94$ & 386 & - & 12.0 & - & -- & - & -- & - & - & -- \\
\hline & $11-19-96$ & 367 & - & 12.0 & -- & -- & - & -- & - & -- & - \\
\hline & $01-07-97$ & 378 & -- & 10.8 & -- & -- & -- & -- & -- & -- & -. \\
\hline & $02-26-97$ & 378 & - & 11.1 & -- & -- & -- & -- & - & -- & - \\
\hline & $04-03-97$ & 372 & - & 11.5 & -- & -- & - & - & -- & -- & - \\
\hline & $05-20-97$ & 360 & -- & 11.8 & -- & - & -- & -- & -- & -- & - \\
\hline & $05-20-97^{2}$ & 360 & -- & 11.8 & -- & -- & -- & -. & -- & -- & - \\
\hline & $06-24-97$ & 365 & - & 11.0 & -- & -- & -- & -- & - & -- & - \\
\hline & $08-19-97$ & 396 & - & 11.2 & - & -- & -- & -- & - & -- & - \\
\hline & $10-15-97$ & - & -- & -- & -- & -- & -- & -- & - & -- & - \\
\hline \multirow[t]{4}{*}{ 10N19W07BACB01 } & $09-27-94$ & 306 & -- & 11.5 & -- & -- & -- & - & -- & -- & - \\
\hline & $09-27-94^{2}$ & 306 & -- & 11.5 & -- & -- & -- & -- & -- & -- & -- \\
\hline & $06-08-95$ & - & - & -- & -- & -- & - & -- & -- & -- & -- \\
\hline & $09-12-95$ & 295 & 7.2 & 13.0 & 9.0 & 40 & 9.6 & 8.8 & 2.5 & 178 & 0 \\
\hline $10 \mathrm{~N} 19 \mathrm{~W} 07 \mathrm{BCBB} 01$ & $08-24-94$ & 366 & - & 13.5 & -- & -- & - & -- & - & -- & - \\
\hline 10N19W07BDAD01 & $09-27-94$ & 351 & -- & 14.0 & -- & -- & -- & - & -- & -- & - \\
\hline 10N19W07BDBB01 & $08-10-94$ & 353 & -- & 12.5 & -- & -- & -- & -- & -- & - & - \\
\hline \multirow[t]{2}{*}{ 10N19W07CAAB0I } & $08-15-94$ & 267 & -- & 12.5 & -- & -- & -- & -- & -- & -- & -- \\
\hline & $09-15-95$ & 251 & 7.2 & 11.0 & 8.7 & 33 & 10 & 3.7 & 1.7 & 145 & 0 \\
\hline 10N19W07CABD01 & $08-15-94$ & 272 & - & 12.0 & -- & -- & -- & -- & -- & -- & - \\
\hline 10N19W07CACC01 & $09-27-94$ & 327 & -- & 12.0 & -- & -- & -- & -- & - & -- & -- \\
\hline 10N19W07CDAA01 & $09-27-94$ & 214 & -- & 11.0 & -- & -- & -- & .- & - & -- & - \\
\hline 10N19W07CDBA01 & $08-15-94$ & 228 & -- & 11.5 & -- & -- & -- & -- & - & - & -- \\
\hline \multirow[t]{2}{*}{$10 \mathrm{~N} 19 \mathrm{~W} 07 \mathrm{CDCC} 01$} & $09-27-94$ & 267 & 6.9 & 11.5 & -- & - & - & -- & - & - & - \\
\hline & 09-13-95 & 267 & 6.9 & 11.5 & 7.4 & 36 & 9.7 & 4.9 & 1.8 & 159 & 0 \\
\hline \multirow[t]{2}{*}{ 10N19W07DABB01 } & $08-28-95$ & 334 & -- & 12.0 & -- & -- & -- & -- & - & -- & -- \\
\hline & $08-28-95^{2}$ & 334 & -- & 12.0 & -- & -. & - & -- & - & - & - \\
\hline $10 \mathrm{~N} 19 \mathrm{~W} 07 \mathrm{DBBC} 01$ & $08-15-94$ & 263 & -- & 13.0 & -- & -- & - & - & -- & -- & - \\
\hline 10N19W07DBDA01 & $08-28-95$ & 199 & - & 11.5 & -- & -- & -- & -- & -- & - & -- \\
\hline 10N19W07DDCD01 & $08-24-94$ & 124 & -- & 11.0 & -- & -- & - & -- & -- & -- & -- \\
\hline \multirow[t]{2}{*}{ 10N19W07DDDC01 } & $08-24-94$ & 185 & -- & 10.5 & - & -- & -- & -- & - & -- & - \\
\hline & $08-24-94^{2}$ & 185 & - & 10.5 & -- & -- & -- & -- & - & -- & - \\
\hline \multirow[t]{10}{*}{ 10N19W08ABBC01 } & $08-02-94$ & 274 & -- & 12.0 & - & -- & -- & - & -- & -- & -- \\
\hline & $11-19-96$ & 403 & - & 11.2 & - & -- & -- & -- & -- & - & - \\
\hline & $01-07-97$ & 443 & -- & 11.1 & -- & -- & - & -- & -- & - & - \\
\hline & $02-26-97$ & 434 & -- & 8.3 & -- & -- & -- & -- & -- & -- & -- \\
\hline & $04-03-97$ & 404 & -- & 11.3 & - & -- & - & -- & - & -- & - \\
\hline & $04-03-97^{2}$ & 404 & - & 11.3 & -- & -- & - & -- & -- & -- & - \\
\hline & $05-20-97$ & 288 & -- & 10.9 & -- & -- & -- & -- & - & - & -- \\
\hline & $06-23-97$ & 273 & -- & 10.9 & -- & -- & -- & -. & -- & -- & -- \\
\hline & 08-19-97 & 445 & -- & 10.8 & -- & -- & -- & -- & -- & -- & -- \\
\hline & $10-15-97$ & - & - & - & -- & - & -- & -- & -- & - & -- \\
\hline \multirow[t]{2}{*}{ 10N19W08ADAD01 } & $08-02-94$ & 339 & - & 14.0 & -- & - & -- & -- & -- & -- & -- \\
\hline & $06-08-95$ & - & - & -- & -- & -- & -- & -- & -- & -. & -- \\
\hline \multirow[t]{3}{*}{ 10N19W08ADDC01 } & $08-02-94$ & 343 & -- & 12.5 & -- & -- & -- & - & -- & - & -- \\
\hline & $06-08-95$ & 343 & -- & 12.5 & - & -- & -- & -- & -- & - & -- \\
\hline & $09-12-95$ & 341 & 8.1 & 13.5 & - & 36 & 12 & 20 & 3.2 & 187 & 0 \\
\hline 10N19W08BADD01 & $09-27-94$ & 337 & -- & 15.5 & -- & -- & - & -- & -- & - & -- \\
\hline \multirow[t]{2}{*}{ 10N19W08BBDD01 } & 08-02-94 & 315 & - & 15.5 & -- & -- & -- & -- & -- & - & -- \\
\hline & $08-02-94^{2}$ & 315 & - & 15.5 & -- & -- & - & -- & -- & -- & - \\
\hline 10N19W08BCAD01 & $08-10-94$ & 271 & -- & 16.5 & -- & -- & - & -- & - & -- & - \\
\hline
\end{tabular}




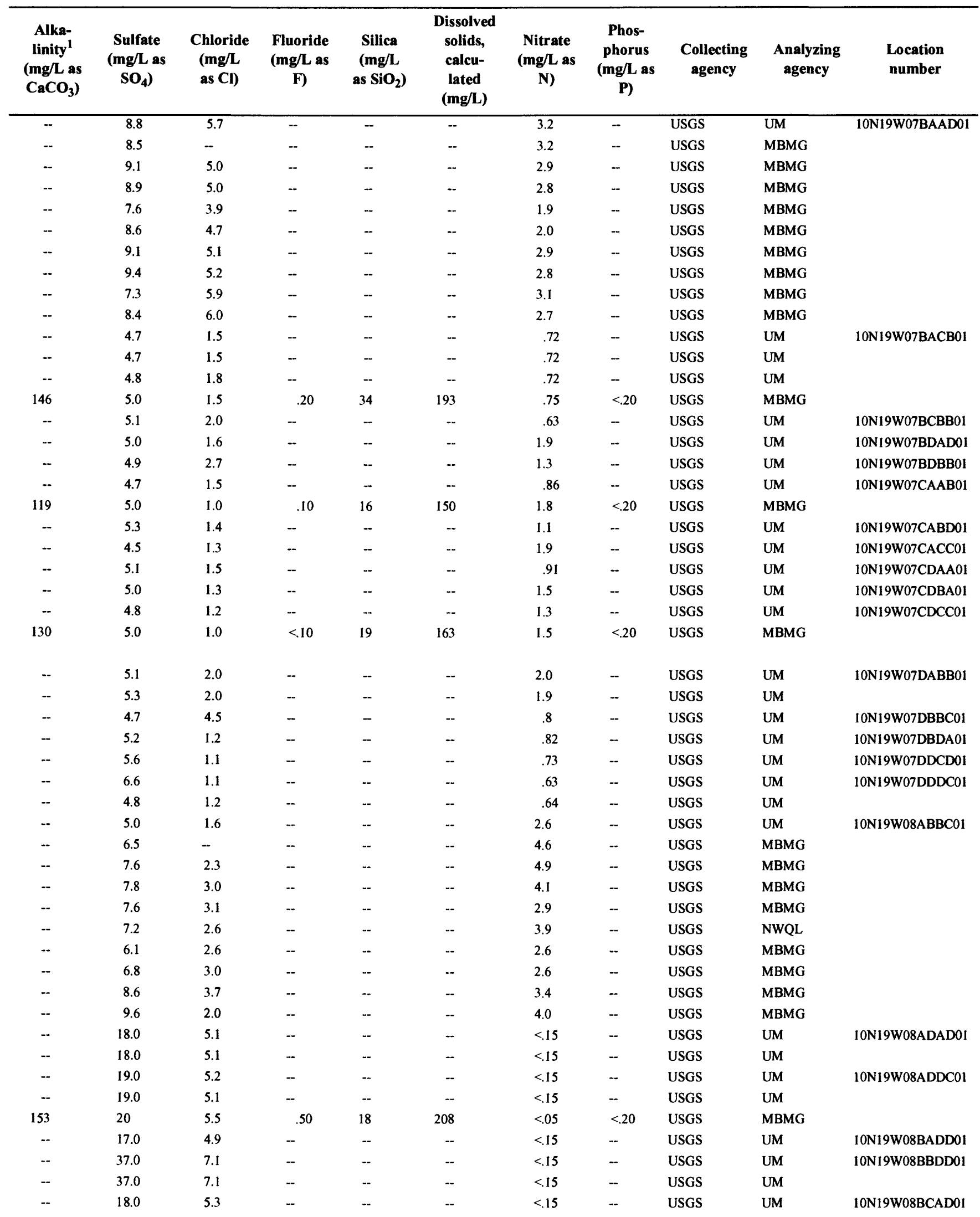


Table 6. Physical properties and major-ion concentrations for water from wells (Continued)

\begin{tabular}{|c|c|c|c|c|c|c|c|c|c|c|c|}
\hline $\begin{array}{l}\text { Location } \\
\text { number }\end{array}$ & Date & $\begin{array}{c}\text { Specific } \\
\text { conduct- } \\
\text { ance, } \\
\text { field } \\
(\mu \mathrm{S} / \mathrm{cm})\end{array}$ & $\begin{array}{c}\text { pH, } \\
\text { field } \\
\text { (stand- } \\
\text { ard } \\
\text { units) }\end{array}$ & $\begin{array}{l}\text { Temper- } \\
\text { ature, } \\
\text { water } \\
\left({ }^{\circ} \mathrm{C}\right)\end{array}$ & $\begin{array}{l}\text { Oxygen, } \\
\text { dis- } \\
\text { solved, } \\
\text { field } \\
\text { (mg/L) }\end{array}$ & $\begin{array}{c}\text { Cal- } \\
\text { cium } \\
(\mathrm{mg} / \mathrm{L} \text { as } \\
\text { Ca) }\end{array}$ & $\begin{array}{c}\text { Magne- } \\
\text { sium } \\
\text { (mg/L as } \\
\text { Mg) }\end{array}$ & $\begin{array}{l}\text { Sodium } \\
\text { (mg/L as } \\
\mathrm{Na})\end{array}$ & $\begin{array}{c}\text { Potas- } \\
\text { sium } \\
(\mathrm{mg} / \mathrm{L} \text { as } \\
\mathrm{K})\end{array}$ & $\begin{array}{c}\text { Bicar- } \\
\text { bonate }^{1} \\
\left(\mathrm{mg}^{-} \mathrm{L} \text { as }\right. \\
\left.\mathrm{HCO}_{3}\right)\end{array}$ & $\begin{array}{c}\text { Carbon- } \\
\text { ate }^{1} \\
\left(\mathrm{mg}^{\mathrm{L}} \mathbf{L} \text { as }\right. \\
\left.\mathrm{CO}_{3}\right)\end{array}$ \\
\hline & $09-13-95$ & 264 & 7.3 & 15.5 & .3 & 23 & 5.0 & 25 & 3.7 & 109 & 0 \\
\hline 10N19W08BCBB01 & $08-15-94$ & 294 & -- & 15.0 & - & - & - & -- & - & - & - \\
\hline 10N19W08BCCC01 & $08-10-94$ & 386 & - & 12.0 & -- & -- & - & -. & - & - & -- \\
\hline 10N19W08BDAB01 & $08-10-94$ & 243 & -- & 15.0 & - & -- & -- & -- & -- & -- & -- \\
\hline 10N19W08BDBB01 & $08-10-94$ & 291 & - & 15.5 & -- & -- & -- & -- & - & - & - \\
\hline 10N19W08CBAA01 & $08-02-94$ & 306 & -- & 11.0 & -- & -- & - & -- & - & -- & - \\
\hline \multirow[t]{8}{*}{ 10N19W08CBDD01 } & $08-15-94$ & 198 & -- & 10.0 & -- & - & -- & -- & -- & -- & -- \\
\hline & $11-19-96$ & 205 & - & 8.8 & -- & - & -- & -- & -- & -- & -- \\
\hline & $01-07-97$ & 219 & - & 8.5 & -- & - & - & -- & - & - & -- \\
\hline & $02-27-97$ & 254 & -- & 9.2 & - & -- & - & -- & - & -- & -- \\
\hline & $04-03-97$ & 255 & -- & 9.0 & - & -- & - & -- & -- & -- & -- \\
\hline & $05-20-97$ & 236 & - & 11.2 & - & -- & -- & - & - & -- & -- \\
\hline & $08-19-97$ & 228 & - & 9.3 & -- & -- & -- & - & -- & -- & -- \\
\hline & $10-15-97$ & -- & -- & -- & - & -- & -- & - & - & -- & -- \\
\hline \multirow[t]{3}{*}{ 10N19W08CDAC01 } & $08-10-94$ & 338 & - & 10.5 & -- & -- & -- & -- & - & -- & - \\
\hline & $06-08-95$ & 338 & -- & 10.5 & -- & -- & - & -- & - & -- & -- \\
\hline & $09-13-95$ & 328 & 7.1 & 10.0 & 8.2 & 45 & 14 & 3.9 & 1.9 & 174 & 0 \\
\hline 10N19W08CDBD01 & $08-28-95$ & 257 & - & 10.0 & -- & -- & -- & - & - & -- & - \\
\hline 10N19W08DAAC01 & $08-24-94$ & 168 & -- & 13.5 & -- & - & - & -- & - & -- & -- \\
\hline \multirow[t]{2}{*}{ 10N19W08DBBD01 } & $08-28-95$ & 195 & - & 13.5 & - & - & -- & -- & -- & -- & -- \\
\hline & $09-12-95$ & 187 & 7.1 & 13.5 & 5.0 & 22 & 6.8 & 6.7 & 2.6 & 111 & 0 \\
\hline \multirow[t]{9}{*}{ 10N19W08DCCB01 } & $08-28-95$ & 274 & - & 11.0 & -- & -- & - & -- & - & - & - \\
\hline & $09-13-95$ & 264 & 7.1 & 10.5 & 8.6 & 35 & 11 & 3.7 & 2.1 & 150 & 0 \\
\hline & $01-07-97$ & -- & - & -- & -- & - & -- & - & -- & - & - \\
\hline & $02-26-97$ & 277 & -- & 10.4 & -- & -- & - & -- & -- & -- & -- \\
\hline & $04-03-97$ & 274 & - & 10.9 & - & -- & - & - & -- & -- & - \\
\hline & $05-20-97$ & 269 & -- & 12.9 & - & -- & - & -- & -- & -- & - \\
\hline & $06-24-97$ & - & - & 16.5 & - & -- & -- & -- & - & -- & - \\
\hline & $08-19-97$ & 288 & -- & 10.5 & -- & -- & -- & -- & -- & -- & -- \\
\hline & $10-15-97$ & - & - & -- & -- & -- & - & -- & -- & -- & -- \\
\hline \multirow[t]{2}{*}{ 10N19W08DCCC01 } & $08-24-94$ & 280 & -- & 11.0 & - & -- & -- & -- & - & - & - \\
\hline & $08-28-95$ & 280 & - & 11.0 & - & -- & - & -- & -- & - & -- \\
\hline \multirow[t]{2}{*}{ 10N19W08DCCC02 } & $03-10-94$ & 266 & 7.1 & 10.5 & -- & 33 & 10 & 3.7 & 2.3 & -- & -- \\
\hline & $10-26-95$ & 258 & 7.2 & 11.0 & -- & -- & - & - & - & -- & -- \\
\hline \multirow[t]{2}{*}{$10 \mathrm{~N} 19 \mathrm{~W} 09 \mathrm{ABCC} 01$} & $08-02-94$ & 341 & -- & 11.0 & -- & - & -- & -- & -- & -- & -- \\
\hline & $06-08-95$ & 341 & - & 11.0 & - & - & -- & -- & - & - & -- \\
\hline \multirow[t]{2}{*}{ 10N19W09BCCC01 } & $09-27-94$ & 201 & -- & 11.0 & -- & -- & - & -- & - & -- & - \\
\hline & $06-08-95$ & 201 & - & 11.0 & -- & -- & -- & -- & - & -- & -- \\
\hline \multirow[t]{2}{*}{$10 \mathrm{~N} 19 \mathrm{~W} 16 \mathrm{BBBC} 01$} & $08-24-94$ & 184 & -- & 13.5 & -- & -- & -- & - & -- & -- & -- \\
\hline & $09-15-95$ & 165 & 7.2 & 13.0 & 7.9 & 15 & 4.3 & 12 & 2.6 & 77 & 0 \\
\hline 10N19W17BAAA01 & $08-10-94$ & 237 & -- & 11.5 & -- & -- & - & -- & -- & - & -- \\
\hline 10N19W17BBDA01 & 08-24-94 & 182 & - & 9.5 & -- & -- & -- & -- & -- & -- & -- \\
\hline 10N19W17BCAB01 & $08-24-94$ & 193 & -- & 10.5 & -- & -- & - & -- & -- & -- & -- \\
\hline 10N19W17DBBC01 & $12-14-95$ & 210 & 7.3 & 12.0 & - & -- & -- & -- & -- & -- & -- \\
\hline 10N19W18AAAA01 & $08-24-94$ & 168 & - & 11.5 & -- & -- & -- & $\cdots$ & - & -- & - \\
\hline \multirow[t]{2}{*}{ 10N19W18AADB01 } & $08-28-95$ & 175 & - & 11.0 & - & -- & - & -- & - & -- & -- \\
\hline & $09-13-95$ & 171 & 6.9 & 10.0 & 8.4 & 21 & 6.8 & 3.7 & 1.8 & 99 & 0 \\
\hline \multirow[t]{2}{*}{ 10N19W18ABAD01 } & $06-08-95$ & - & -- & -- & -- & -- & - & -- & - & -- & - \\
\hline & $06-08-95^{2}$ & - & - & - & -- & -- & -- & - & - & -- & -- \\
\hline 10N19W18ADDC01 & $06-08-95$ & - & -- & - & - & -- & - & -- & - & -- & -- \\
\hline 10N19W18DBBA01 & $06-08-95$ & 186 & 6.9 & 10.0 & -. & -- & - & -- & - & -- & - \\
\hline
\end{tabular}




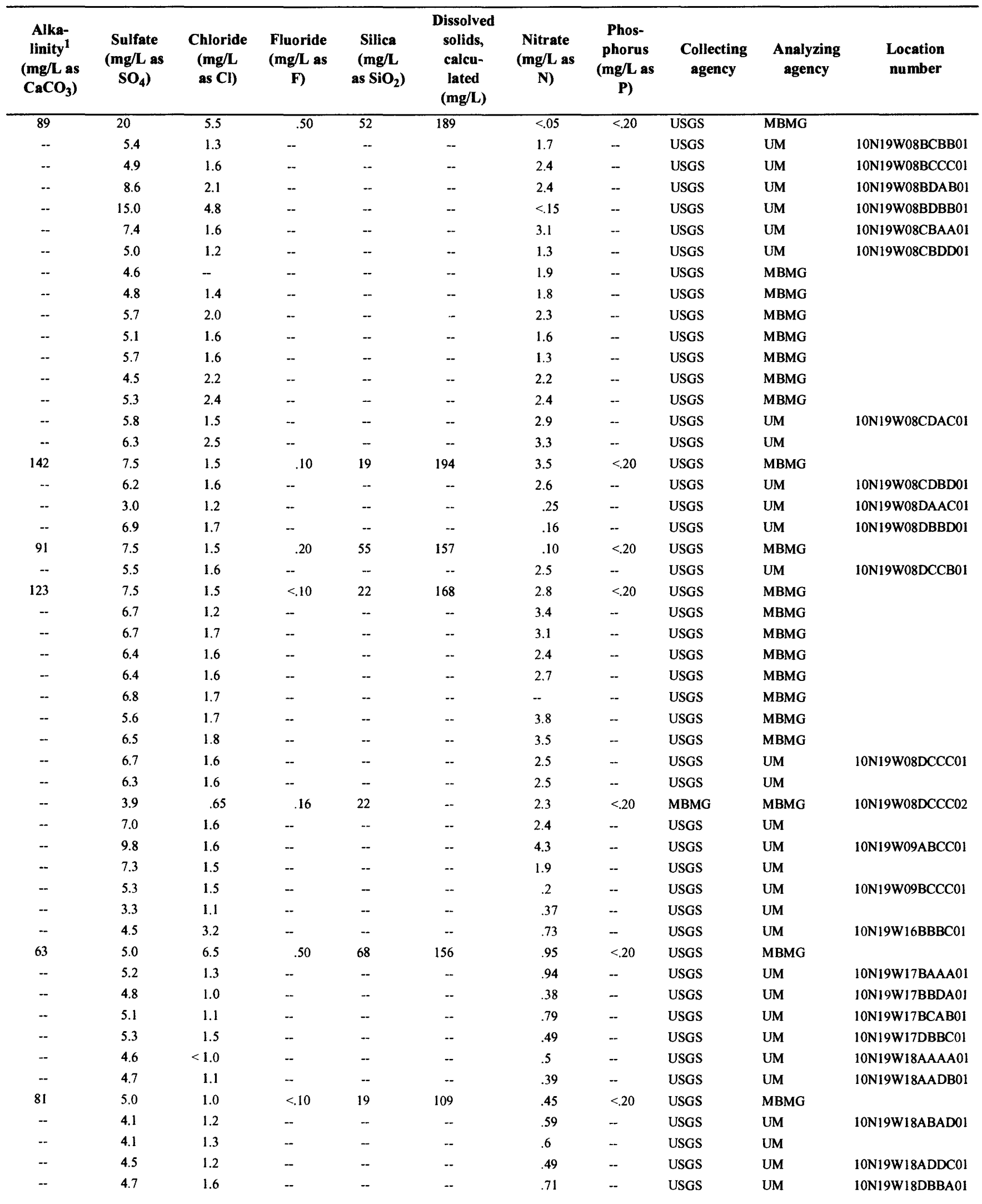


Table 6. Physical properties and major-ion concentrations for water from wells (Continued)

\begin{tabular}{|c|c|c|c|c|c|c|c|c|c|c|c|}
\hline $\begin{array}{l}\text { Location } \\
\text { number }\end{array}$ & Date & $\begin{array}{c}\text { Specific } \\
\text { conduct- } \\
\text { ance, } \\
\text { field } \\
(\mu \mathrm{S} / \mathrm{cm})\end{array}$ & $\begin{array}{c}\text { pH, } \\
\text { field } \\
\text { (stand- } \\
\text { ard } \\
\text { units) }\end{array}$ & $\begin{array}{c}\text { Temper- } \\
\text { ature, } \\
\text { water } \\
\left({ }^{\circ} \mathrm{C}\right)\end{array}$ & $\begin{array}{c}\text { Oxygen, } \\
\text { dis- } \\
\text { solved, } \\
\text { field } \\
\text { (mg/L) }\end{array}$ & $\begin{array}{c}\begin{array}{c}\text { Cal- } \\
\text { cium }\end{array} \\
\text { (mg/L as } \\
\text { Ca) }\end{array}$ & $\begin{array}{l}\text { Magne- } \\
\text { sium } \\
(\mathrm{mg} / \mathrm{L} \text { as } \\
\mathrm{Mg})\end{array}$ & $\begin{array}{c}\text { Sodium } \\
\text { (mg/L as } \\
\text { Na) }\end{array}$ & $\begin{array}{l}\text { Potas- } \\
\text { sium } \\
(\mathrm{mg} / \mathrm{L} \text { as } \\
\mathrm{K})\end{array}$ & $\begin{array}{c}\text { Bicar- } \\
\text { bonate }^{1} \\
(\mathrm{mg} / \mathrm{L} \text { as } \\
\left.\mathrm{HCO}_{3}\right)\end{array}$ & $\begin{array}{l}\text { Carbon- } \\
\text { ate }^{1} \\
(\mathrm{mg} / \mathrm{L} \text { as } \\
\left.\mathrm{CO}_{3}\right)\end{array}$ \\
\hline & $09-13-95$ & 186 & 6.9 & 10.0 & 9.1 & 23 & 7.2 & 4.0 & 1.9 & 106 & 0 \\
\hline 10N19W19BDAD01 & $10-26-95$ & 214 & 6.9 & 10.5 & -- & -- & - & - & - & -. & - \\
\hline 10N19W19DDAA01 & $10-26-95$ & 210 & 7.3 & 14.0 & -- & -- & - & - & - & -- & -- \\
\hline 10N19W20BAAD01 & $10-26-95$ & 191 & 7.1 & 13.5 & -- & -- & -- & -. & -- & -- & - \\
\hline \multirow[t]{2}{*}{ 10N19W21CBBA01 } & $10-26-95$ & 243 & 7.0 & 14.5 & -- & -- & -- & -- & -- & -- & -- \\
\hline & $10-26-95^{2}$ & 243 & 7.0 & 14.5 & -- & -- & - & - & -- & -- & - \\
\hline 10N19W29ABAC01 & $10-26-95$ & 274 & 7.4 & 13.5 & - & -- & - & -- & - & -- & - \\
\hline 10N19W30CACD01 & $10-26-95$ & 236 & 7.2 & 11.0 & -- & -- & -- & -- & - & -- & -- \\
\hline 09N20W19ADCA01 & $10-26-95$ & 141 & 6.4 & 12.0 & -- & -- & - & -- & -- & .. & -- \\
\hline 09N20W20ACAB01 & $10-12-95$ & 118 & 6.4 & 11.0 & -- & -- & - & -- & -- & -- & -- \\
\hline \multirow[t]{2}{*}{ 09N20W20ACAD01 } & $06-06-96$ & 128 & 6.5 & 10.0 & - & -- & - & - & -- & - & -- \\
\hline & $06-06-96^{2}$ & 128 & 6.5 & 10.0 & -- & -- & - & -- & - & -- & - \\
\hline 09N20W20CDCD01 & $09-14-95$ & 230 & 8.3 & 10.0 & .4 & 30 & .7 & 18 & 1.5 & 130 & 0 \\
\hline 09N20W21 ACCB01 & $10-12-95$ & 42.9 & 6.2 & 12.5 & -- & -- & - & -- & -- & -- & - \\
\hline $09 \mathrm{~N} 20 \mathrm{~W} 21 \mathrm{CCAC} 01$ & $12-14-95$ & 287 & 7.4 & 10.5 & -- & -- & -- & -- & -- & -- & -- \\
\hline \multirow[t]{2}{*}{ 09N20W28CCBB01 } & $10-12-95$ & 193 & 6.6 & 10.5 & -- & -- & -- & -- & -- & -- & -- \\
\hline & $10-12-95^{2}$ & 193 & 6.6 & 10.5 & - & -- & - & -- & -- & - & -- \\
\hline 09N20W29ADCC01 & $10-26-95$ & 256 & 6.8 & 10.5 & - & -- & - & -- & - & -- & - \\
\hline 09N19W33BDBC01 & $08-25-95$ & 177 & 7.4 & 18.0 & -- & -. & -- & - & - & - & - \\
\hline \multirow[t]{2}{*}{ 08N21W27DCBC01 } & $03-10-94$ & 67.0 & 6.3 & 5.5 & -- & 8.4 & 1.6 & 3.2 & 1.0 & 38 & 0 \\
\hline & $06-06-96$ & 70.6 & 6.6 & 8.5 & -- & -- & -- & -- & -- & -- & -- \\
\hline 08N20W01 ACCB01 & $08-25-95$ & 648 & 7.6 & 10.5 & -. & -- & -- & -- & - & -- & - \\
\hline 08N20W01 DAAD01 & $08-20-92$ & 622 & 7.6 & 11.5 & 6.8 & 50 & 13 & 71 & 2.0 & 359 & 0 \\
\hline 08N20W01 DABD01 & $10-26-95$ & 626 & 7.7 & 9.5 & - & -- & - & - & -- & -- & -. \\
\hline 08N20W02CBDB01 & $08-25-95$ & 306 & 7.7 & 13.5 & -- & - & -- & -- & -- & -- & - \\
\hline 08N20W11BDAA01 & $08-25-95$ & 564 & 7.6 & 15.0 & -- & -- & -- & -. & - & - & - \\
\hline 08N20W11CCAD01 & $08-25-95$ & 60.9 & 7.6 & 14.0 & -- & - & - & -- & - & -- & - \\
\hline \multirow[t]{10}{*}{ 08N20W12BAAA01 } & $10-12-95$ & 812 & 7.9 & 11.0 & - & - & -- & -- & - & -- & -- \\
\hline & $11-19-96$ & 813 & -- & 10.3 & -- & - & -- & -- & - & -- & - \\
\hline & $01-07-97$ & 838 & -- & 8.6 & -- & - & - & - & -- & -- & -- \\
\hline & $02-26-97$ & 854 & -- & 8.7 & -- & - & - & -- & - & -- & - \\
\hline & $04-03-97$ & 860 & -- & 9.0 & -- & - & -- & -- & - & - & - \\
\hline & $04-03-97^{2}$ & 860 & -- & 9.0 & -- & -. & -- & -- & - & -- & -- \\
\hline & $05-20-97$ & 839 & - & 9.8 & -- & - & - & -- & -- & -. & - \\
\hline & $06-24-97$ & 866 & -- & 9.8 & -- & -- & - & -- & - & -. & - \\
\hline & $08-19-97$ & 723 & -- & 9.3 & -- & - & -- & -- & - & - & - \\
\hline & $10-15-97$ & - & -- & -- & -- & -- & -- & -- & -- & - & - \\
\hline 08N20W13BBDB01 & $10-12-95$ & 622 & 7.3 & 11.5 & -- & -- & - & -- & -- & - & -- \\
\hline \multirow[t]{2}{*}{ 08N20W14ABDB01 } & $09-15-95$ & 579 & 7.5 & 14.5 & 7.8 & 69 & 16 & 34 & 8.0 & 316 & 0 \\
\hline & $10-12-95$ & 579 & 7.5 & 14.5 & -- & -- & -- & -- & - & -- & - \\
\hline \multirow[t]{3}{*}{ 08N20W23CDDD01 } & $08-20-92$ & 386 & 7.4 & 15.0 & 9.2 & 34 & 7.4 & 29 & 7.8 & 170 & 0 \\
\hline & $12-14-95$ & 384 & 7.8 & 12.0 & -- & - & - & -- & - & -- & -- \\
\hline & $12-14-95^{2}$ & 384 & 7.8 & 12.0 & -- & - & -- & -- & -- & -- & -- \\
\hline \multirow[t]{2}{*}{ 08N20W26BAAC01 } & $03-10-94$ & 602 & 7.6 & 16.0 & -. & 42 & 13 & 68 & 8.2 & 258 & 0 \\
\hline & $06-06-96$ & 416 & 7.2 & 16.0 & -- & -- & -- & -- & - & -- & -- \\
\hline \multirow[t]{2}{*}{ 08N19W04BDAA01 } & 03-09-94 & -- & 7.4 & 4.5 & -- & 22 & 4.6 & 2.6 & 1.8 & -- & - \\
\hline & $08-25-95$ & 169 & 7.9 & 8.5 & -- & -- & -- & - & -- & -- & -- \\
\hline \multirow[t]{2}{*}{ 08N19W07CBBD01 } & $03-10-94$ & 756 & 8.1 & 9.0 & - & 33 & 14 & 130 & 2.0 & -- & - \\
\hline & $08-25-95$ & 766 & 8.0 & 10.0 & -- & -- & -- & - & - & -- & - \\
\hline \multirow[t]{2}{*}{08 N19W10BBCA01 } & $08-25-95$ & 288 & 7.8 & 13.5 & - & -- & - & -- & -- & -- & - \\
\hline & $08-25-95^{2}$ & 288 & 7.8 & 13.5 & - & -. & -- & -. & - & - & - \\
\hline 08N19W11CDBB01 & $08-20-92$ & 227 & 7.2 & 8.0 & 7.2 & 30 & 6.3 & 7.1 & 2.1 & 127 & 0 \\
\hline
\end{tabular}




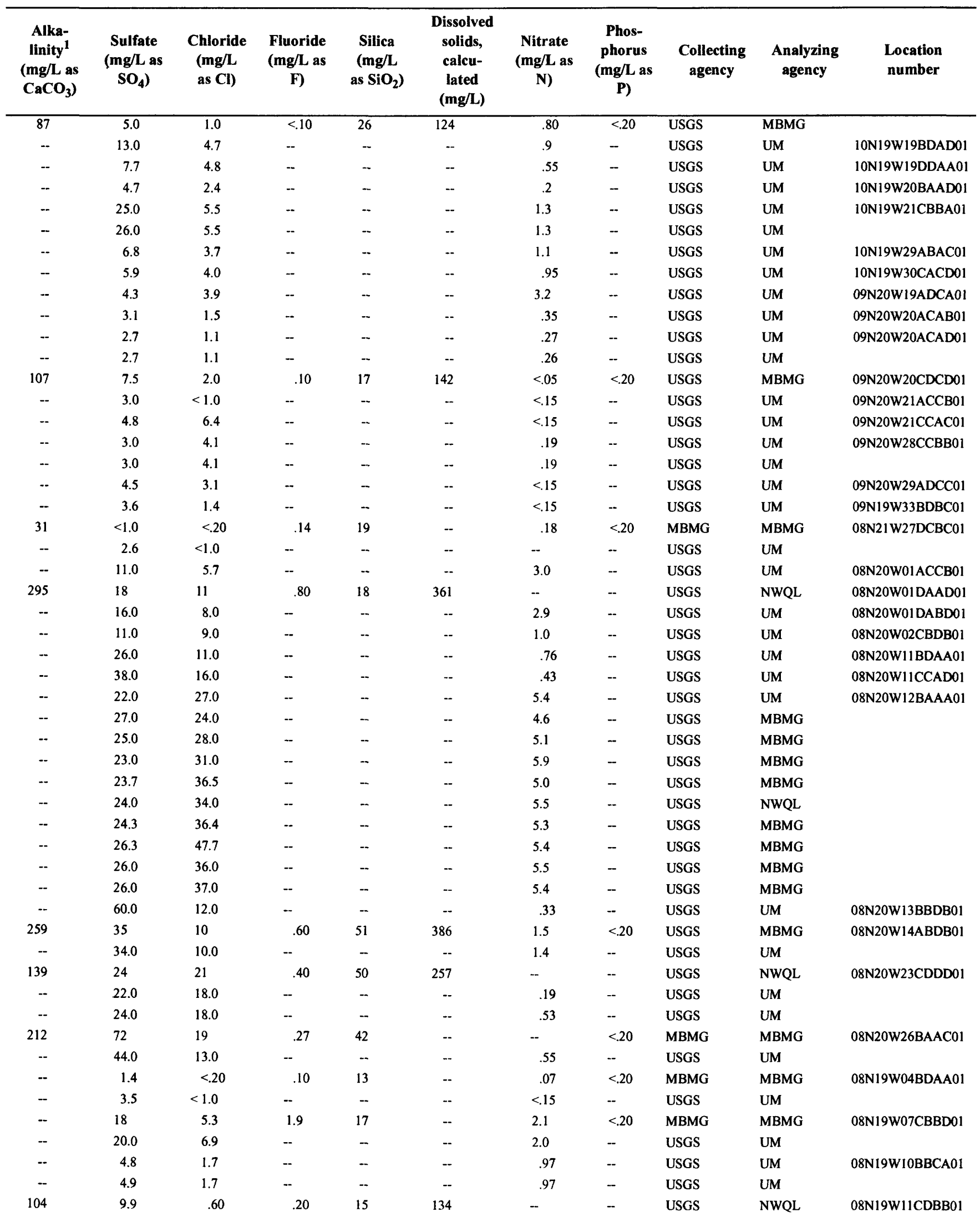

TABLE 691 
Table 6. Physical properties and major-ion concentrations for water from wells (Continued)

\begin{tabular}{|c|c|c|c|c|c|c|c|c|c|c|c|}
\hline $\begin{array}{l}\text { Location } \\
\text { number }\end{array}$ & Date & $\begin{array}{c}\text { Specific } \\
\text { conduct- } \\
\text { ance, } \\
\text { field } \\
(\mu \mathrm{S} / \mathrm{cm})\end{array}$ & $\begin{array}{c}\text { pH, } \\
\text { field } \\
\text { (stand- } \\
\text { ard } \\
\text { units) }\end{array}$ & $\begin{array}{c}\text { Temper- } \\
\text { ature, } \\
\text { water } \\
\left({ }^{\circ} \mathrm{C}\right)\end{array}$ & $\begin{array}{l}\text { Oxygen, } \\
\text { dis- } \\
\text { solved, } \\
\text { field } \\
\text { (mg/L) }\end{array}$ & $\begin{array}{c}\begin{array}{c}\text { Cal- } \\
\text { cium }\end{array} \\
(\mathrm{mg} / \mathrm{L} \text { as } \\
\text { Ca) }\end{array}$ & $\begin{array}{l}\text { Magne- } \\
\text { sium } \\
\text { (mg/L as } \\
\text { Mg) }\end{array}$ & $\begin{array}{c}\text { Sodium } \\
\text { (mg/L as } \\
\mathrm{Na})\end{array}$ & $\begin{array}{l}\text { Potas- } \\
\text { sium } \\
\text { (mg/L as } \\
\text { K) }\end{array}$ & $\begin{array}{c}\text { Bicar- } \\
\text { bonate }^{1} \\
(\mathrm{mg} / \mathrm{L} \text { as } \\
\left.\mathrm{HCO}_{3}\right)\end{array}$ & $\begin{array}{c}\text { Carbon- } \\
\text { ate }^{1} \\
(\mathrm{mg} / \mathrm{L} \text { as } \\
\left.\mathrm{CO}_{3}\right)\end{array}$ \\
\hline & $10-26-95$ & 233 & 7.2 & 8.5 & - & - & - & - & -- & -- & -- \\
\hline \multirow[t]{3}{*}{ 07N21W13BBAD01 } & $08-17-92$ & 96.0 & 6.8 & 11.0 & 7.4 & 8.3 & 1.5 & 8.7 & 1.7 & 54 & 0 \\
\hline & $08-17-92^{2}$ & 96.0 & 6.8 & 11.0 & 7.4 & 8.2 & 1.5 & 8.7 & 1.6 & 54 & 0 \\
\hline & $12-14-95$ & 82.2 & 7.6 & 9.5 & - & -- & -- & -- & - & -- & -- \\
\hline \multirow[t]{2}{*}{ 07N21W25CABC01 } & $08-17-92$ & 86.0 & 6.5 & 11.0 & 1.5 & 6.1 & 2.0 & 7.5 & 1.2 & 45 & 0 \\
\hline & $12-14-95$ & 89.5 & 6.9 & 10.0 & - & -- & -- & -- & - & -- & - \\
\hline \multirow[t]{3}{*}{ 07N21W36DDDC01 } & $06-20-84$ & 34.0 & 5.5 & 10.3 & -- & 3.3 & .7 & 2.4 & 1.0 & 20 & 0 \\
\hline & $03-09-94$ & 32.0 & 6.0 & 11.0 & -- & 3.8 & .9 & 2.2 & 1.6 & - &.- \\
\hline & $08-25-95$ & 48.9 & 6.6 & 14.0 & -- & - & -- & -- & - & - & - \\
\hline 07N20W32DDDA02 & $03-09-94$ & 345 & 7.1 & 11.5 & -- & 45 & 10 & 12 & 3.7 & - & - \\
\hline 07N20W34CCCD01 & $07-27-95$ & 473 & 7.6 & 10.5 & - & -- & - & -- & -- & - & -- \\
\hline 07N20W34CDDB01 & $07-27-95$ & 417 & 7.6 & 12.0 & -- & -- & - & -- & - & -- & -- \\
\hline $07 \mathrm{~N} 20 \mathrm{~W} 36 \mathrm{CCCA} 01$ & $12-14-95$ & 313 & 7.8 & 12.0 & - & -- & - & - & - & -- & - \\
\hline 06N21W01 ACDA01 & $05-01-95$ & 28.0 & 6.7 & 10.0 & - & -- & -- & -- & - & - & - \\
\hline 06N21W01CADD01 & $04-18-95$ & 71.0 & 6.9 & 11.0 & - & -- & -- & -- & - & -- & - \\
\hline 06N21W01CBAB01 & $05-01-95$ & 74.0 & 7.0 & 10.0 & - & -- & - & - & -- & -- & - \\
\hline \multirow[t]{10}{*}{ 06N21W02ABBD01 } & $03-09-94$ & 82.0 & 6.1 & 11.5 & - & 10 & 2.5 & 2.9 & .70 & -- & -- \\
\hline & $08-17-95$ & 90.3 & 7.3 & 15.0 & - & -- & -- & - & - & - & -- \\
\hline & $11-18-96$ & 89.0 & -- & 11.0 & - & -- & -- & - & -- & -- & -- \\
\hline & $01-06-97$ & 88.6 & - & 9.7 & - & -- & -- & -- & - & -- & -- \\
\hline & $02-25-97$ & 86.5 & - & 9.2 & -- & -- & -- & -- & - & - & -- \\
\hline & $04-02-97$ & 80.0 & - & 11.2 & -- & -- & - & -- & -- & -- & -- \\
\hline & $05-19-97$ & 83.0 & - & 13.5 & -- & -- & - & -- & - & -- & -- \\
\hline & $06-23-97$ & 86.0 & - & 12.4 & -- & -- & -- & -- & -- & -- & - \\
\hline & $08-18-97$ & 103 & -- & 11.7 & -- & -- & -- & -- & -- & -- & -- \\
\hline & $10-14-97$ & -- & -- & -- & -- & -- & -- & -- & -- & -- & -- \\
\hline 06N21W02CADD01 & $05-02-95$ & 25.8 & 6.7 & 10.0 & - & -- & - & -- & -- & -- & -- \\
\hline 06N21W03ACBA01 & $05-01-95$ & 25.4 & 6.8 & 9.0 & -- & -- & - & -- & - & -- & - \\
\hline \multirow[t]{10}{*}{ 06N21W03CAAC01 } & $05-01-95$ & 88.6 & 6.5 & 9.5 & - & -- & - & -- & - & -- & -- \\
\hline & $11-18-96$ & 81.0 & - & 10.9 & - & -- & - & - & - & - & -- \\
\hline & $01-06-97$ & 89.6 & - & 7.6 & -- & -- & - & - & -- & -- & -- \\
\hline & $02-25-97$ & - & - & -- & -- & -- & -- & -- & -- & -- & -- \\
\hline & $04-02-97$ & 85.0 & - & 6.9 & -- & - & -- & - & - & -- & - \\
\hline & $04-02-97^{2}$ & 85.0 & -- & 6.9 & - & -- & -- & - & - & -- & - \\
\hline & $04-02-97^{2}$ & 85.0 & -- & 6.9 & -- & -- & - & - & - & -- & - \\
\hline & $06-23-97$ & 76.0 & - & 10.7 & -- & - & - & - & - & -- & -- \\
\hline & 08-18-97 & 80.0 & -- & 11.3 & -- & -- & - & -- & - & -- & -- \\
\hline & $10-14-97$ & -- & -- & - & -- & -- & - & -- & - & -- & -- \\
\hline 06N21W03CCDD01 & $05-01-95$ & 197 & 7.3 & 8.5 & -- & -- & - & -- & -- & -- & -- \\
\hline \multirow[t]{2}{*}{ 06N21W03DDAA01 } & 05-01-95 & 87.5 & 6.5 & 10.0 & - & -- & -- & -- & - & -- & -- \\
\hline & 09-07-95 & 119 & 5.7 & 14.5 & 6.3 & 11 & 3.0 & 7.3 & 2.2 & 41 & 0 \\
\hline \multirow[t]{2}{*}{ 06N21W09DADA01 } & $05-01-95$ & 266 & 8.5 & 7.5 & - & -- & -- & -- & - & -- & - \\
\hline & $09-07-95$ & 263 & 8.1 & 14.5 & .4 & 22 & 6.1 & 29 & .44 & 151 & 0 \\
\hline 06N21W10BDDD01 & $05-01-95$ & 109 & 7.2 & 6.5 & -- & -- & -- & -- & - & -- & - \\
\hline \multirow[t]{3}{*}{ 06N21W11ABAA01 } & $06-18-84$ & 102 & 6.8 & 11.5 & -- & 6.0 & 1.6 & 12.4 & 1.6 & 59 & 0 \\
\hline & $05-01-95$ & 102 & 7.5 & 9.5 & -- & - & -- & -- & - & -- & -- \\
\hline & 09-06-95 & 100 & 6.8 & 12.0 & .4 & 5.7 & 1.6 & 11 & 1.4 & 59 & 0 \\
\hline 06N21W11CAAA01 & $04-18-95$ & 136 & 6.8 & 8.5 & - & $\cdots$ & -- & -- & - & -- & -- \\
\hline 06N21W11CBCA01 & $05-01-95$ & 144 & 7.0 & 6.5 & - & -- & - & -- & - & - & - \\
\hline \multirow[t]{2}{*}{ 06N21W11CBDC01 } & $05-01-95$ & 161 & 7.8 & 11.0 & - & - & -- & -- & - & -- & - \\
\hline & $05-01-95^{2}$ & 161 & 7.8 & 11.0 & - & -- & - & -- & - & - & -- \\
\hline
\end{tabular}




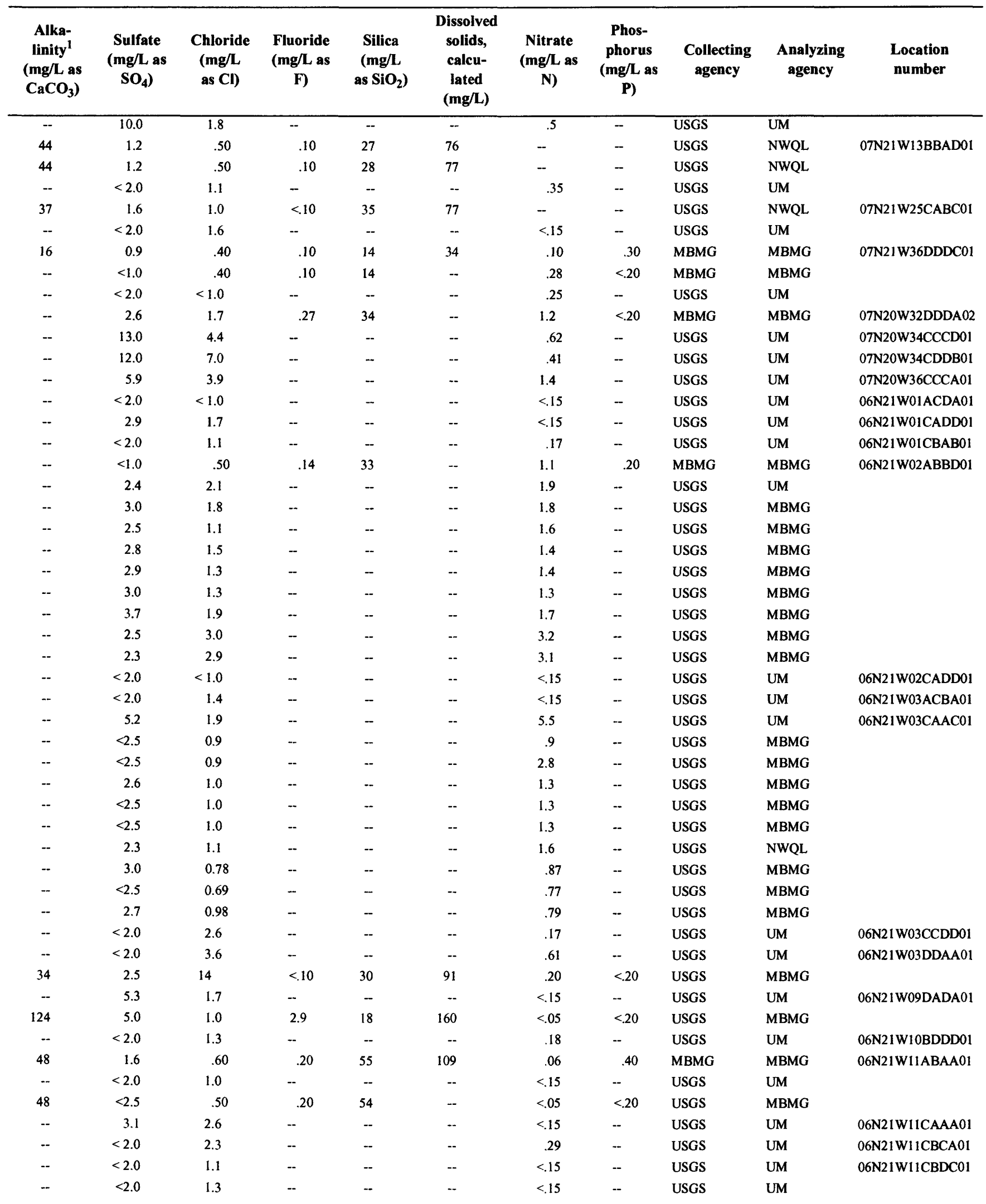


Table 6. Physical properties and major-ion concentrations for water from wells (Continued)

\begin{tabular}{|c|c|c|c|c|c|c|c|c|c|c|c|}
\hline $\begin{array}{l}\text { Location } \\
\text { number }\end{array}$ & Date & $\begin{array}{c}\text { Specific } \\
\text { conduct- } \\
\text { ance, } \\
\text { field } \\
(\mu \mathrm{S} / \mathrm{cm})\end{array}$ & $\begin{array}{c}\text { pH, } \\
\text { field } \\
\text { (stand- } \\
\text { ard } \\
\text { units) }\end{array}$ & $\begin{array}{c}\text { Temper- } \\
\text { ature, } \\
\text { water } \\
\left({ }^{\circ} \mathrm{C}\right)\end{array}$ & $\begin{array}{l}\text { Oxygen, } \\
\text { dis- } \\
\text { solved, } \\
\text { field } \\
(\mathrm{mg} / \mathrm{L})\end{array}$ & 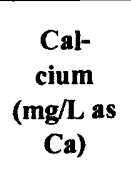 & $\begin{array}{c}\text { Magne- } \\
\text { sium } \\
(\mathrm{mg} / \mathrm{L} \mathrm{as} \\
\mathrm{Mg})\end{array}$ & $\begin{array}{c}\text { Sodium } \\
\text { (mg/L as } \\
\mathrm{Na})\end{array}$ & $\begin{array}{l}\text { Potas- } \\
\text { sium } \\
(\mathrm{mg} / \mathrm{L} \text { as } \\
\mathrm{K})\end{array}$ & $\begin{array}{c}\text { Bicar- } \\
\text { bonate }^{1} \\
(\mathrm{mg} / \mathrm{L} \mathrm{as} \\
\left.\mathrm{HCO}_{3}\right)\end{array}$ & $\begin{array}{l}\text { Carbon- } \\
\text { ate }^{1} \\
(\mathrm{mg} / \mathrm{L} \mathrm{as} \\
\left.\mathrm{CO}_{3}\right)\end{array}$ \\
\hline \multirow[t]{2}{*}{ 06N21W11CDCB01 } & $06-15-95$ & 121 & 7.2 & 12.0 & - & -- & - & - & - & -- & -- \\
\hline & $09-06-95$ & 105 & 6.6 & 10.0 & .3 & 7.6 & 2.2 & 10 & 1.5 & 62 & 0 \\
\hline 06N21W11DCCA01 & $10-26-94$ & 210 & 7.8 & 10.0 & -- & -- & - & -- & - & -- & -- \\
\hline $06 \mathrm{~N} 21 \mathrm{~W} 12 \mathrm{ABAB} 01$ & $04-18-95$ & 59.0 & 6.6 & 10.0 & -- & .. & - & - & - & -- & -- \\
\hline \multirow[t]{2}{*}{ 06N21W12BDDD01 } & $04-18-95$ & 149 & 6.9 & 9.5 & -- & - & -- & -- & - & -- & - \\
\hline & 09-06-95 & 133 & 6.3 & 10.0 & 1.8 & 11 & 2.8 & 10 & 1.6 & 78 & 0 \\
\hline 06N21W13BADC01 & $04-18-95$ & 143 & 7.8 & 11.5 & - & - & - & -- & - & -- & -- \\
\hline \multirow[t]{9}{*}{ 06N21W13BBAB01 } & $04-18-95$ & 90.0 & 7.6 & 11.0 & -- & -- & - & - & - & -- & - \\
\hline & $11-18-96$ & 87.8 & - & 10.9 & -- & - & - & .- & - & -- & -- \\
\hline & $01-06-97$ & 88.9 & -- & 10.6 & - & -- & -- & -- & - & - & - \\
\hline & $02-25-97$ & 79.1 & -- & 10.8 & -- & -- & - & -- & - & -- & - \\
\hline & $04-02-97$ & 80.0 & -- & 13.0 & -- & -- & -- & -- & - & -- & -- \\
\hline & $05-19-97$ & 81.0 & -- & 14.9 & -- & - & - & -- & - & - & -- \\
\hline & $06-23-97$ & 83.0 & -- & 12.9 & -- & -- & - & -- & - & -- & -- \\
\hline & $08-18-97$ & 86.0 & -- & 13.0 & - & -. & -- & -- & - & -- & -. \\
\hline & $10-14-97$ & - & -- & -- & -- & -- & -- & -- & - & -- & -- \\
\hline 06N21W13CCCD01 & $10-26-94$ & 89.9 & 6.2 & 11.5 & -- & -. & - & - & - & -- & -- \\
\hline 06N21W13DBBD01 & $05-01-95$ & 106 & 6.4 & 11.0 & -- & -. & - & -- & - & -- & -- \\
\hline 06N21W14BCBD01 & $05-01-95$ & 57.3 & 6.9 & 10.0 & - & - & - & -- & -. & -- & - \\
\hline \multirow[t]{3}{*}{ 06N21W14BDAC01 } & $10-26-94$ & 82.2 & 7.1 & 12.0 & -- & -- & - & -- & - & - & - \\
\hline & $09-06-95$ & 84.5 & 7.0 & 12.0 & 9.2 & 12 & 1.8 & 2.5 & .59 & 47 & 0 \\
\hline & $09-06-95^{2}$ & 84.5 & 7.0 & 12.0 & 9.2 & 12 & 1.8 & 2.5 & .79 & 47 & 0 \\
\hline 06N21W14DAAD01 & $10-26-94$ & 58.3 & 6.1 & 9.0 & - & -- & - & - & - & - & - \\
\hline 06N21W15ABBB01 & $05-01-95$ & 75.8 & 6.7 & 10.0 & -- & - & - & -- & - & -. & - \\
\hline 06N21W15ADBC01 & $06-15-95$ & 101 & 7.6 & 12.0 & -- & -- & -- & -- & - & -- & - \\
\hline \multirow[t]{4}{*}{ 06N21W15CDDD01 } & $06-10-84$ & 53.0 & 6.2 & 10.8 & -- & 5.8 & 1.3 & 3.4 & .60 & 34 & 0 \\
\hline & $08-17-92$ & 52.0 & 6.3 & 9.5 & 8.4 & 5.2 & 1.1 & 3.1 & .60 & 28 & 0 \\
\hline & $10-26-94$ & 50.3 & 6.4 & 9.5 & -- & -- & - & -- & - & -- & -- \\
\hline & $10-26-94^{2}$ & 50.3 & 6.4 & 9.5 & -- & -- & - & - & - & -. & -- \\
\hline 06N21W21 ADDB01 & $10-26-94$ & 122 & 7.2 & 11.0 & - & -- & - & -- & - & -- & - \\
\hline \multirow[t]{2}{*}{ 06N21W22AADC01 } & $05-01-95$ & 40.1 & 6.7 & 9.5 & -. & -- & - & -- & - & -- & -- \\
\hline & $09-06-95$ & 39.0 & 5.7 & 9.5 & 6.5 & 3.4 & 1.2 & 2.5 & 1.4 & 22 & 0 \\
\hline 06N21W22BCCA01 & $08-30-94$ & 124 & 9.6 & 11.0 & -- & -- & - & -- & - & -. & -- \\
\hline 06N21W22CACA01 & $08-30-94$ & 120 & 6.4 & 13.5 & -- & -. & -- & -. & - & -- & - \\
\hline 06N21W23ADAA01 & $10-26-94$ & 47.2 & 6.2 & 11.5 & -- & -- & - & -- & - & -- & -- \\
\hline 06N21W23BABB01 & $10-26-94$ & 36.2 & 6.3 & 12.5 & -- & - & - & -- & - & -- & -- \\
\hline 06N21W23BDDD01 & $08-30-94$ & 36.2 & 6.3 & 12.5 & -- & - & -- & -- & - & -- & - \\
\hline \multirow[t]{4}{*}{$06 \mathrm{~N} 21 \mathrm{~W} 23 \mathrm{CABC} 01$} & $06-15-95$ & 79.0 & 7.1 & 10.0 & -- & -- & - & - & - & - & - \\
\hline & $06-15-95^{2}$ & 79.0 & 7.1 & 10.0 & - & - & -- & -- & - & - & - \\
\hline & $08-09-95$ & 79.0 & 7.1 & 10.0 & -- & -- & - & - & - & - & -- \\
\hline & $09-06-95$ & 79.4 & 6.6 & 11.5 & 7.4 & 7.3 & 1.8 & 7.3 & .59 & 44 & 0 \\
\hline \multirow[t]{2}{*}{ 06N21W23CBCB01 } & $06-08-84$ & 99.0 & 6.7 & 11.0 & -- & 10 & 2.5 & 9.1 & .7 & 62.5 & 0 \\
\hline & $09-15-94$ & 99.0 & 6.7 & 11.0 & -- & -- & - & -- & - & -- & - \\
\hline 06N21W23CDCB01 & $08-30-94$ & 105 & 6.6 & 12.0 & -- & -- & -- & -- & - & -- & -- \\
\hline \multirow[t]{3}{*}{ 06N21W23DADA01 } & $09-15-94$ & 48.4 & 6.1 & 10.5 & -- & - & -- & -- & - & -- & -- \\
\hline & $09-15-94^{2}$ & 48.4 & 6.1 & 10.5 & -- & -- & -- & - & - & -- & -- \\
\hline & $08-08-95$ & 48.4 & 6.1 & 10.5 & -- & -- & - & -- & - & -- & - \\
\hline \multirow[t]{4}{*}{ 06N21W23DADD01 } & 09-15-94 & 54.0 & 6.1 & 11.0 & -- & .. & -. & -- & - & -- & -- \\
\hline & $09-15-94^{2}$ & 54.0 & 6.1 & 11.0 & -- & -- & - & -- & -- & -- & -- \\
\hline & $09-28-94$ & 54.0 & 6.1 & 11.0 & - & -- & -- & -- & - & -- & -- \\
\hline & $09-28-94^{2}$ & 54.0 & 6.1 & 11.0 & - & -- & - & -. & -- & -- & .- \\
\hline
\end{tabular}




\begin{tabular}{|c|c|c|c|c|c|c|c|c|c|c|}
\hline $\begin{array}{c}\text { Alka- } \\
\text { linity } \\
(\mathrm{mg} / \mathrm{L} \text { as } \\
\left.\mathrm{CaCO}_{3}\right)\end{array}$ & $\begin{array}{c}\text { Sulfate } \\
(\mathrm{mg} / \mathrm{L} \text { as } \\
\left.\mathrm{SO}_{4}\right)\end{array}$ & $\begin{array}{c}\text { Chloride } \\
\text { (mg/L } \\
\text { as } \mathrm{Cl})\end{array}$ & $\begin{array}{c}\text { Fluoride } \\
\text { (mg/L as } \\
\text { F) }\end{array}$ & $\begin{array}{c}\text { Silica } \\
(\mathrm{mg} / \mathrm{L} \\
\left.\text { as } \mathrm{SiO}_{2}\right)\end{array}$ & $\begin{array}{l}\text { Dissolved } \\
\text { solids, } \\
\text { calcu- } \\
\text { lated } \\
\text { (mg/L) }\end{array}$ & $\begin{array}{c}\text { Nitrate } \\
\text { (mg/L as } \\
\text { N) }\end{array}$ & $\begin{array}{c}\text { Phos- } \\
\text { phorus } \\
\text { (mg/L as } \\
\text { P) }\end{array}$ & $\begin{array}{l}\text { Collecting } \\
\text { agency }\end{array}$ & $\begin{array}{l}\text { Analyzing } \\
\text { agency }\end{array}$ & $\begin{array}{c}\text { Location } \\
\text { number }\end{array}$ \\
\hline-- & $<2.0$ & $<1.0$ & -- & - & -- & $<.15$ & -- & USGS & UM & 06N21W11CDCB01 \\
\hline 51 & 2.5 & .50 & .20 & 40 & 97 & $<.05$ & $<.20$ & USGS & MBMG & \\
\hline-- & 11.0 & 7.2 & -- & -- & -- & .7 & -- & USGS & UM & 06N21W11DCCA01 \\
\hline-- & $<2.0$ & $<1.0$ & -- & -- & -- & .16 & -- & USGS & UM & 06N21W12ABAB01 \\
\hline-- & $<2.0$ & 2.1 & -- & -- & -- & $<.15$ & -- & USGS & UM & 06N21W12BDDD01 \\
\hline 64 & $<2.5$ & 1.5 & .20 & 29 & - & $<.05$ & $<.20$ & USGS & MBMG & \\
\hline-- & $<2.0$ & 1.0 & -- & -- & -- & .6 & - & USGS & UM & 06N21W13BADC01 \\
\hline-- & $<2.0$ & 1.1 & -- & -- & -- & .4 & - & USGS & UM & 06N21W13BBAB01 \\
\hline-- & $<2.5$ & .8 & -- & - & - & .4 & -- & USGS & MBMG & \\
\hline-- & $<2.5$ & $<.05$ & -- & -- & -- & .4 & -- & USGS & MBMG & \\
\hline- & $<2.5$ & 1.0 & -- & -- & - & .4 & - & USGS & MBMG & \\
\hline- & $<2.5$ & .8 & -- & -- & -- & .3 & - & USGS & MBMG & \\
\hline- & $<2.5$ & .9 & - & - & - & .3 & - & USGS & MBMG & \\
\hline-- & $<2.5$ & .86 & -- & -- & -- & .37 & -- & USGS & MBMG & \\
\hline- & $<2.5$ & .89 & - & -- & -- & .34 & - & USGS & MBMG & \\
\hline-- & $<2.5$ & .87 & -- & - & -- & .3 & - & USGS & MBMG & \\
\hline-- & 2.3 & 2.7 & -- & -- & -- & .8 & - & USGS & UM & $06 \mathrm{~N} 21 \mathrm{~W} 13 \mathrm{CCCD} 01$ \\
\hline-- & $<2.0$ & 2.8 & -- & - & -- & .3 & - & USGS & UM & 06N21W13DBBD01 \\
\hline-- & $<2.0$ & $<1.0$ & - & -- & -- & $<.15$ & - & USGS & UM & 06 N21W14BCBD01 \\
\hline-- & $<2.0$ & $<1.0$ & -- & -- & -- & $<.15$ & -- & USGS & UM & $06 \mathrm{~N} 21 \mathrm{~W} 14 \mathrm{BDAC} 01$ \\
\hline 39 & $<2.5$ & $<.50$ & .10 & 35 & -- & .10 & $<20$ & USGS & MBMG & \\
\hline 39 & $<2.5$ & $<.50$ & .20 & 35 & -- & .10 & $<.20$ & USGS & MBMG & \\
\hline-- & $<2.0$ & $<1.0$ & -- & -- & -- & .3 & -- & USGS & UM & 06N21W14DAAD01 \\
\hline-- & $<2.0$ & $<1.0$ & -- & -- & -- & $<.15$ & -- & USGS & UM & $06 \mathrm{~N} 21 \mathrm{~W} 15 \mathrm{ABBB} 01$ \\
\hline- & 2.3 & 1.7 & -- & - & - & .16 & -- & USGS & UM & 06N21W15ADBC01 \\
\hline 28 & .70 & .30 & .10 & 31 & 61 & .15 & .40 & MBMG & MBMG & 06N21W15CDDD01 \\
\hline 23 & .80 & .20 & $<.10$ & 27 & 52 & -- & -- & USGS & NWQL & \\
\hline- & $<2.0$ & $<1.0$ & - & -- & -- & .18 & -- & USGS & UM & \\
\hline-- & $<2.0$ & $<1.0$ & - & - & -- & .16 & -- & USGS & UM & \\
\hline- & $<2.0$ & 1.2 & -- & -- &.- & $<.15$ & -- & USGS & UM & 06N21W21ADDB01 \\
\hline-- & $<2.0$ & $<1.0$ & -- & -- & -- & $<.15$ & -- & USGS & UM & 06N21W22AADC01 \\
\hline 18 & $<2.5$ & $<.50$ & $<.10$ & 22 & -- & .15 & $<.20$ & USGS & MBMG & \\
\hline- & $<2.0$ & 1.9 & -- & -- & - & .17 & -- & USGS & UM & 06N21W22BCCA01 \\
\hline- & $<2.0$ & 2.7 & - & -- & -- & .25 & -- & USGS & UM & $06 \mathrm{~N} 21 \mathrm{~W} 22 \mathrm{CACA} 01$ \\
\hline-- & $<2.0$ & 4.6 & - & -- & - & $<.15$ & -- & USGS & UM & $06 \mathrm{~N} 21 \mathrm{~W} 23 \mathrm{ADAA} 01$ \\
\hline-- & $<2.0$ & $<1.0$ & -- & -- & -- & $<.15$ & -- & USGS & UM & $06 \mathrm{~N} 21 \mathrm{~W} 23 \mathrm{BABB} 01$ \\
\hline- & $<2.0$ & $<1.0$ & - & -- & -- & $<.15$ & -- & USGS & UM & 06N21W23BDDD01 \\
\hline-- & 2.3 & $<1.0$ & -- & -- & -- & .16 & - & USGS & UM & $06 \mathrm{~N} 21 \mathrm{~W} 23 \mathrm{CABC} 01$ \\
\hline-- & 2.7 & $<1.0$ & - & -- & -- & .22 & -- & USGS & UM & \\
\hline-- & $<2.0$ & $<1.0$ & - & -- & -- & .21 & -- & USGS & UM & \\
\hline 36 & $<2.5$ & $<.50$ & $<1.0$ & 42 & -- & .15 & $<.20$ & USGS & MBMG & \\
\hline 51 & 1.5 & .6 & .3 & 45 & 102 & .28 & .3 & MBMG & MBMG & $06 \mathrm{~N} 21 \mathrm{~W} 23 \mathrm{CBCB} 01$ \\
\hline- & $<2.0$ & 1.1 & -- & - & -- & .28 & - & USGS & UM & \\
\hline$\cdots$ & $<2.0$ & 1.4 & -- & - & -- & .31 & - & USGS & UM & 06N21W23CDCB01 \\
\hline -. & $<2.0$ & $<1.0$ & - & - & - & $<.15$ & - & USGS & UM & 06N21W23DADA01 \\
\hline- & $<2.0$ & $<1.0$ & -- & - & - & $<.15$ & -- & USGS & UM & \\
\hline-- & $<2.0$ & $<1.0$ & -- & -- & -- & .22 & -- & USGS & UM & \\
\hline-- & $<2.0$ & 1.2 & -- & -- & -- & .27 & -- & USGS & UM & 06N21W23DADD01 \\
\hline- & $<2.0$ & 1.1 & -- & -- & -- & .18 & -- & USGS & UM & \\
\hline- & $<2.0$ & $<1.0$ & -- & -- & -- & .34 & - & USGS & UM & \\
\hline- & $<2.0$ & $<1.0$ & -- & -- & - & .26 & -- & USGS & UM & \\
\hline
\end{tabular}


Table 6. Physical properties and major-ion concentrations for water from wells (Continued)

\begin{tabular}{|c|c|c|c|c|c|c|c|c|c|c|c|}
\hline $\begin{array}{l}\text { Location } \\
\text { number }\end{array}$ & Date & $\begin{array}{c}\text { Specific } \\
\text { conduct- } \\
\text { ance, } \\
\text { field } \\
(\mu \mathrm{S} / \mathrm{cm})\end{array}$ & $\begin{array}{l}\text { pH, } \\
\text { field } \\
\text { (stand- } \\
\text { ard } \\
\text { units) }\end{array}$ & $\begin{array}{l}\text { Temper- } \\
\text { ature, } \\
\text { water } \\
\left({ }^{\circ} \mathrm{C}\right)\end{array}$ & $\begin{array}{l}\text { Oxygen, } \\
\text { dis- } \\
\text { solved, } \\
\text { field } \\
\text { (mg/L) }\end{array}$ & $\begin{array}{l}\text { Cal- } \\
\text { cium } \\
\text { (mg/L as } \\
\text { Ca) }\end{array}$ & $\begin{array}{l}\text { Magne- } \\
\text { sium } \\
\text { (mg/L as } \\
\mathrm{Mg} \text { ) }\end{array}$ & $\begin{array}{l}\text { Sodium } \\
\text { (mg/L as } \\
\mathrm{Na} \text { ) }\end{array}$ & $\begin{array}{l}\text { Potas- } \\
\text { sium } \\
\text { (mg/L as } \\
\mathrm{K} \text { ) }\end{array}$ & $\begin{array}{c}\text { Bicar- } \\
\text { bonate }^{1} \\
(\mathrm{mg} / \mathrm{L} \text { as } \\
\left.\mathrm{HCO}_{3}\right)\end{array}$ & $\begin{array}{c}\text { Carbon- } \\
\text { ate }^{1} \\
(\mathrm{mg} / \mathrm{L} \text { as } \\
\left.\mathrm{CO}_{3}\right)\end{array}$ \\
\hline \multirow[t]{2}{*}{ 06N21W23DBDA01 } & $07-14-95$ & 43.9 & 6.7 & 11.0 & - & -- & - & -- & - & $-\cdot$ & $\cdots$ \\
\hline & $08-09-95$ & 43.9 & 6.7 & 11.0 & -- & $-\cdot$ & -- & -- & - & -- & - \\
\hline \multirow[t]{2}{*}{ 06N21W23DDAA01 } & $09-15-94$ & 50.8 & 6.3 & 14.5 & -- & - & - & -- & -- & - & - \\
\hline & $08-09-95$ & 50.8 & 6.3 & 14.5 & -- & -- & -- & -- & - & - & - \\
\hline \multirow[t]{3}{*}{ 06N21 W23DDAD01 } & $09-15-94$ & 51.7 & 6.3 & 12.5 & - & - & -- & -- & -- & - & -- \\
\hline & $08-08-95$ & 51.7 & 6.3 & 12.5 & - & -- & -- & -- & - & - & -- \\
\hline & $09-05-95$ & 55.0 & 6.0 & 12.5 & 7.1 & 4.4 & 1.4 & 3.9 & 1.7 & 23 & 0 \\
\hline \multirow[t]{3}{*}{ 06N21W23DDBB01 } & $09-15-94$ & 51.4 & 6.3 & 10.0 & -- & -- & $\cdots$ & - & -- & -- & -- \\
\hline & $08-08-95$ & 51.4 & 6.3 & 10.0 & -- & -- & - & - & - & -- & - \\
\hline & $09-05-95$ & 52.2 & 6.0 & 10.5 & 4.4 & 5.0 & 1.1 & 3.3 & 2.4 & 22 & 0 \\
\hline \multirow[t]{2}{*}{$06 \mathrm{~N} 21 \mathrm{~W} 23 \mathrm{DDCB} 01$} & $09-15-94$ & 73.3 & 6.6 & 10.0 & - & - & -- & - & -- & -- & -- \\
\hline & $08-08-95$ & 73.3 & 6.6 & 10.0 & -- & - & -- & $\cdots$ & -- & -- & -- \\
\hline \multirow[t]{2}{*}{ 06N21 W23DDDA01 } & $09-15-94$ & 59.2 & 6.2 & 11.0 & -- & -- & - & -- & - & - & $\cdots$ \\
\hline & $08-08-95$ & 59.2 & 6.2 & 11.0 & - & -- & - & -- & - & -- & -- \\
\hline \multirow[t]{2}{*}{ 06N2 I W24BAAC01 } & $10-26-94$ & 92.9 & 6.6 & 9.0 & - & - & - & $\cdots$ & -- & -- & -- \\
\hline & $09-06-95$ & 93.0 & 6.1 & 9.0 & 0.4 & 11 & 3.1 & 3.0 & 1.1 & 53 & 0 \\
\hline \multirow[t]{12}{*}{ 06N21 W24CCAC01 } & $09-15-94$ & 63.3 & 6.2 & 12.5 & -- & -- & - & - & - & -- & -- \\
\hline & $08-08-95$ & 63.3 & 6.2 & 12.5 & -- & -- & - & - & - & -- & -- \\
\hline & $09-05-95$ & 70.1 & 5.8 & 12.5 & 6.7 & 5.7 & 2.2 & 4.3 & 1.9 & 29 & 0 \\
\hline & $11-18-96$ & 69.0 & - & 12.3 & -- & -- & -- & -- & -- & - & -- \\
\hline & $01-06-97$ & 74.0 & -- & 10.6 & -- & -- & -- & -- & - & - & -- \\
\hline & $02-25-97$ & 71.8 & - & 11.8 & -- & -- & -- & -- & - & - & - \\
\hline & $04-02-97$ & 70.0 & -- & 12.3 & -- & -- & - & - & - & - & -- \\
\hline & $05-19-97$ & 66.0 & - & 14.0 & -- & -- & - & -- & - & -- & -- \\
\hline & $06-23-97$ & 70.0 & - & 11.7 & -- & -- & -- & -- & -- & -- & -- \\
\hline & $08-18-97$ & 71.0 & - & 11.7 & - & - & -- & - & -- & -- & - \\
\hline & $08-18-97^{2}$ & 71.0 & - & 11.7 & - & -- & - & -- & -- & - & - \\
\hline & $10-14-97$ & -- & - & -- & -- & -- & -- & - & -- & - & - \\
\hline 06N21W24CCBB01 & $09-15-94$ & 60.2 & 6.3 & 14.0 & -- & - & - & -- & -- & - & - \\
\hline \multirow[t]{4}{*}{ 06N21 W24CCBB02 } & $09-15-94$ & 57.3 & 6.5 & 14.5 & - & - & -- & -- & -- & - & - \\
\hline & $09-15-94^{2}$ & 57.3 & 6.5 & 14.5 & - & -- & - & - & - & - & - \\
\hline & $08-08-95$ & 57.3 & 6.5 & 14.5 & - & - & -- & - & - & -- & -- \\
\hline & $08-08-95^{2}$ & 57.3 & 6.5 & 14.5 & - & - & - & -- & -- & - & - \\
\hline \multirow[t]{2}{*}{ 06N21 W24CCCB0I } & $09-15-94$ & 72.0 & 5.8 & 11.0 & - & -- & -- & - & - & -- & - \\
\hline & $08-09-95$ & 72.0 & 5.8 & 11.0 & -- & -- & - & -- & -- & - & - \\
\hline \multirow[t]{2}{*}{ 06N21 W25DBAA01 } & $08-18-92$ & 284 & 6.9 & 12.5 & 6.4 & 38 & 9.0 & 4.6 & 2.9 & 171 & 0 \\
\hline & $12-14-95$ & 293 & 7.2 & 12.0 & - & - & - & -- & - & -- & -- \\
\hline 06N21 W26AADD01 & $08-30-94$ & 90.3 & 6.6 & 10.0 & - & -- & - & -- & - & -- & -- \\
\hline 06N21 W26ABAD0I & $08-30-94$ & 212 & 7.2 & 11.5 & -- & -- & - & - & -- & - & -- \\
\hline \multirow[t]{2}{*}{ 06N21 W26BBCA01 } & $08-30-94$ & 45.3 & 6.3 & 10.5 & - & -- & - & - & -- & - & -- \\
\hline & $08-30-94^{2}$ & 45.3 & 6.3 & 10.5 & -- & -- & -- & - & - & -- & - \\
\hline 06N21W26CBAB01 & $08-30-94$ & 97.9 & 6.7 & 11.5 & - & -- & - & -- & - & -- & - \\
\hline 06N2 I W26DBAD01 & $03-08-94$ & 146 & 6.9 & 10.5 & -- & 13 & 3.2 & 13 & 3.8 & -- & - \\
\hline 06N21W26DBDD01 & $09-15-94$ & 107 & 7.2 & 13.0 & - & - & -- & -- & - & -- & -- \\
\hline \multirow[t]{7}{*}{ 06N21 W27ADBC01 } & $08-30-94$ & 108 & 6.4 & 10.0 & -- & -- & -- & - & - & -- & - \\
\hline & $11-18-96$ & 111 & -- & 10.4 & -- & -- & - & -- & -- & -- & -- \\
\hline & $11-18-96^{2}$ & 111 & -- & 10.4 & -- & -- & - & -- & -- & -- & -- \\
\hline & $01-06-97$ & 113 & - & 9.6 & -- & -- & - & -- & - & -- & - \\
\hline & $02-25-97$ & 111 & -- & 10.9 & - & -- & -- & - & - & -- & -- \\
\hline & $04-02-97$ & 108 & -- & 11.1 & -- & $\cdots$ & - & - & - & -- & - \\
\hline & $05-19-97$ & 107 & -- & 12.9 & -- & -- & -- & -- & -- & -- & -- \\
\hline
\end{tabular}




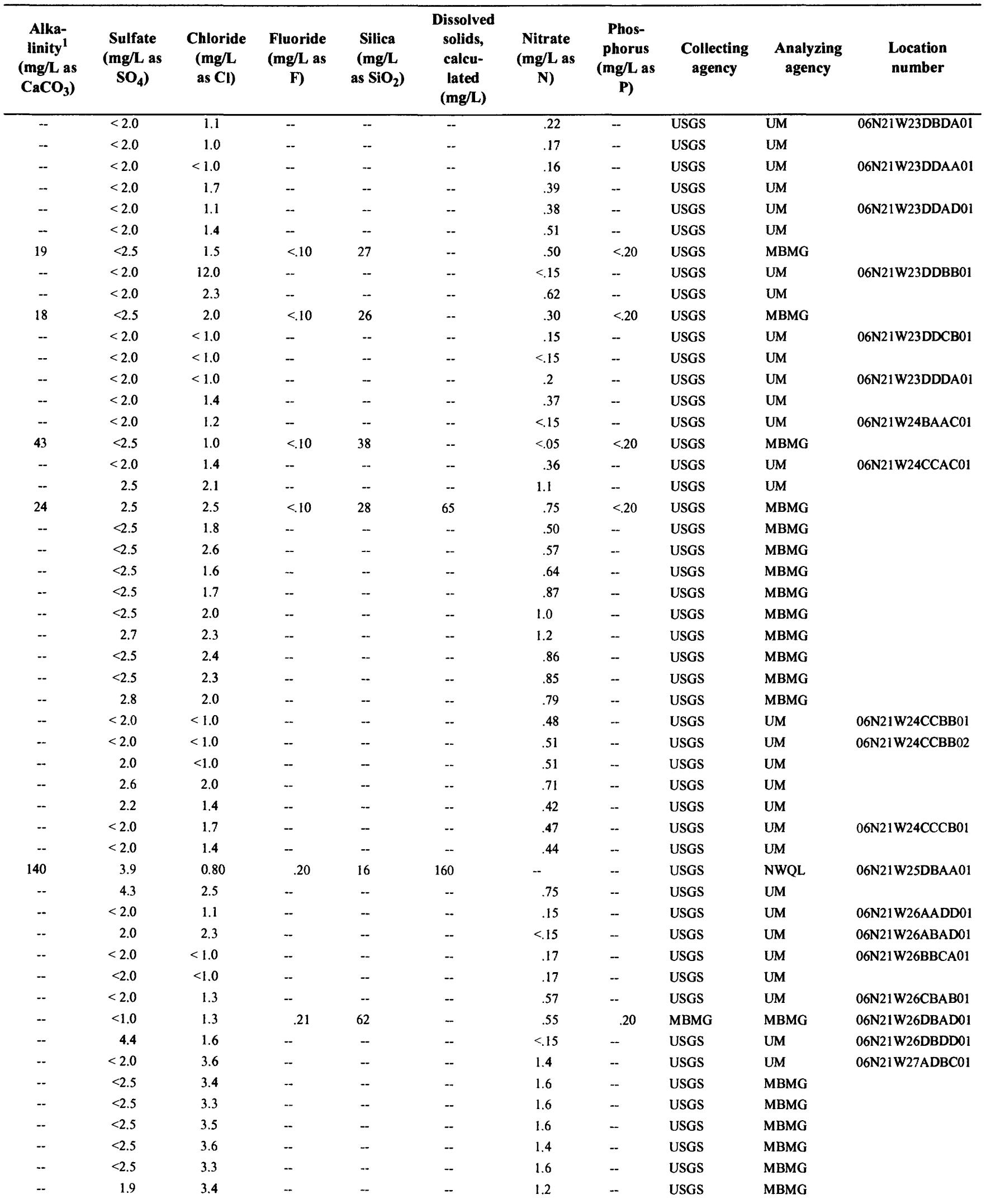


Table 6. Physical properties and major-ion concentrations for water from wells (Continued)

\begin{tabular}{|c|c|c|c|c|c|c|c|c|c|c|c|}
\hline $\begin{array}{l}\text { Location } \\
\text { number }\end{array}$ & Date & $\begin{array}{c}\text { Specific } \\
\text { conduct- } \\
\text { ance, } \\
\text { field } \\
(\mu \mathrm{S} / \mathrm{cm})\end{array}$ & $\begin{array}{c}\text { pH, } \\
\text { field } \\
\text { (stand- } \\
\text { ard } \\
\text { units) }\end{array}$ & $\begin{array}{c}\text { Temper- } \\
\text { ature, } \\
\text { water } \\
\left({ }^{\circ} \mathrm{C}\right)\end{array}$ & $\begin{array}{l}\text { Oxygen, } \\
\text { dis- } \\
\text { solved, } \\
\text { field } \\
(\mathrm{mg} / \mathrm{L})\end{array}$ & 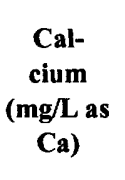 & $\begin{array}{l}\text { Magne- } \\
\text { sium } \\
\text { (mg/L as } \\
\text { Mg) }\end{array}$ & $\begin{array}{l}\text { Sodium } \\
\text { (mg/L as } \\
\text { Na) }\end{array}$ & $\begin{array}{c}\text { Potas- } \\
\text { sium } \\
(\mathrm{mg} / \mathrm{L} \text { as } \\
\mathrm{K})\end{array}$ & $\begin{array}{c}\text { Bicar- } \\
\text { bonate } \\
(\mathrm{mg} / \mathrm{L} \text { as } \\
\left.\mathrm{HCO}_{3}\right)\end{array}$ & $\begin{array}{c}\text { Carbon- } \\
\text { ate } \\
(\mathrm{mg} / \mathrm{L} \text { as } \\
\left.\mathrm{CO}_{3}\right)\end{array}$ \\
\hline & $06-23-97$ & 107 & -- & 11.8 & - & - & $\overline{--}$ & - & -- & -- & -- \\
\hline & $08-18-97$ & 108 & -- & 11.0 & -- & -- & - & - & - & -- & -- \\
\hline & $10-14-97$ & -- & - & -- & -- & -- & -- & -- & -- & -- & -- \\
\hline 06N21W27BABA01 & $08-30-94$ & 99.2 & 6.7 & 12.0 & -- & -- & -- & -- & -- & -- & -- \\
\hline \multirow[t]{2}{*}{ 06N21W27BBAA01 } & $03-08-94$ & 83.0 & 6.4 & 9.5 & - & 8.4 & 1.1 & 8.3 & 1.0 & -- & -- \\
\hline & $08-15-95$ & 83.9 & 7.8 & 11.0 & -- & -- & -- & -- & -- & -- & -- \\
\hline 06N21 W34ABCD01 & $08-15-95$ & 100 & 6.6 & 11.0 & -- & -- & - & -- & - & -- & -- \\
\hline \multirow[t]{2}{*}{ 06N20W01 BABB01 } & $07-27-95$ & 396 & 8.0 & 14.5 & -- & -- & -- & -- & - & -- & -- \\
\hline & $09-14-95$ & 378 & 8.0 & 13.5 & 6.6 & 21 & 3.0 & 60 & 4.2 & 199 & 0 \\
\hline \multirow[t]{12}{*}{ 06N20W01CDCD01 } & $06-20-84$ & 413 & 7.2 & 9.5 & -- & 56 & 13.1 & 19 & 2.2 & 260 & 0 \\
\hline & $06-15-95$ & 395 & 7.3 & 10.5 & -- & - & -- & -- & -- & -- & -- \\
\hline & $09-07-95$ & 204 & 7.4 & 11.0 & 7.4 & 24 & 5.6 & 13 & 1.5 & 119 & 0 \\
\hline & $11-19-96$ & 324 & $\ldots$ & 10.9 & -- & -- & -- & -- & - & -- & -- \\
\hline & $01-07-97$ & 389 & - & 9.2 & -- & - & - & -- & - & -- & -- \\
\hline & $02-26-97$ & 428 & -- & 8.5 & -- & -- & -- & -- & - & -- & -- \\
\hline & 04-03-97 & 418 & - & 9.0 & -- & -- & -- & -- & - & -- & -- \\
\hline & $04-03-97^{2}$ & 418 & -. & 9.0 & -- & -- & -- & -- & -- & -- & - \\
\hline & $05-20-97$ & 421 & - & 9.3 & -- & -- & -- & -- & -- & -- & -- \\
\hline & $06-24-97$ & 446 & - & 10.2 & -- & -- & -- & -- & - & -- & -- \\
\hline & $08-19-97$ & 330 & - & 10.7 & -- & -- & - & -- & - & -- & -- \\
\hline & $10-15-97$ & - & - & -- & -- & -- & -- & -- & -- & -- & -- \\
\hline 06N20W02AADC01 & $07-27-95$ & 453 & 7.3 & 15.0 & -- & - & -- & -- & -- & -- & -- \\
\hline 06N20W02BBDA01 & $07-14-95$ & 661 & 7.8 & 12.5 & -- & -- & -- & -- & -- & -- & -- \\
\hline \multirow[t]{2}{*}{ 06N20W02CCAA01 } & $07-27-95$ & 558 & 7.6 & 10.5 & -- & -- & - & -- & -- & -- & -- \\
\hline & $07-27-95^{2}$ & 558 & 7.6 & 10.5 & -- & - & -- & -. & - & -- & - \\
\hline 06N20W02DCDC01 & $07-14-95$ & 532 & 7.5 & 12.0 & -- & -- & -- & -- & -- & -- & -- \\
\hline 06N20W03BDBB01 & $07-27-95$ & 328 & 7.7 & 12.0 & -. & -- & -- & -- & -- & - & -- \\
\hline \multirow[t]{2}{*}{ 06N20W03BDCC01 } & $03-09-94$ & 499 & 7.1 & 10.0 & -- & 72 & 9.0 & 22 & 4.0 & - & -- \\
\hline & $07-14-95$ & 505 & 7.2 & 11.5 & -- & - & -- & -- & - & -- & - \\
\hline 06N20W03CCDB01 & $06-15-95$ & 463 & 7.6 & 10.5 & -- & -- & -- & -- & -- & -- & -- \\
\hline 06N20W04AABC01 & $07-27-95$ & 449 & 7.3 & 11.5 & -- & -- & -- & -- & - & -- & -- \\
\hline 06N20W04ACCD01 & $07-27-95$ & 385 & 7.3 & 12.5 & -- & -- & -- & -- & - & - & -- \\
\hline \multirow[t]{8}{*}{ 06N20W04ADCD01 } & $06-15-95$ & 359 & 7.6 & 12.0 & -- & -- & -- & -- & -- & -- & -- \\
\hline & $01-07-97$ & 364 & -- & 8.2 & - & -- & - & -- & -- & -- & -- \\
\hline & $02-27-97$ & 365 & - & 9.5 & - & -- & -- & -- & -- & -- & - \\
\hline & $04-03-97$ & 361 & -- & 9.7 & -- & -- & -- & - & -- & - & -- \\
\hline & $05-20-97$ & 353 & -- & 10.2 & -- & -- & -- & -- & -- & - & -- \\
\hline & $06-24-97$ & 359 & - & 10.7 & -- & -- & -- & -- & -- & -- & -- \\
\hline & $08-19-97$ & 365 & -- & 11.1 & - & -- & -- & -- & -- & - & - \\
\hline & $10-15-97$ & - & - & -- & - & -- & -- & -- & -- & -- & -- \\
\hline 06N20W04CCCD01 & $06-15-95$ & 363 & 7.5 & 10.5 & -- & -- & -- & -- & -- & -- & -- \\
\hline \multirow[t]{9}{*}{ 06N20W04DCCB01 } & $06-15-95$ & 436 & 7.5 & 13.0 & - & -- & -- & -- & -- & -- & -- \\
\hline & $06-15-95^{2}$ & 436 & 7.5 & 13.0 & - & -. & -- & -- & -- & -- & -- \\
\hline & $09-14-95$ & 390 & 7.5 & 12.5 & 8.2 & 49 & 15 & 14 & 2.9 & 244 & 0 \\
\hline & $01-07-97$ & 393 & - & 10.7 & -- & -- & -- & -- & -- & -- & -- \\
\hline & $01-07-97^{2}$ & 393 & -- & 10.7 &.- & - & - & -- & - & -- & -- \\
\hline & $02-26-97$ & 403 & - & 10.3 & -- & -- & -- & -- & -- & -- & -- \\
\hline & 04-03-97 & 411 & -- & 11.3 & -- & -- & -- & -- & -- & -- & -- \\
\hline & $04-03-97^{2}$ & 411 & -- & 11.3 & -- & -- & -- & -- & -- & -- & - \\
\hline & $05-20-97$ & 411 & -- & 11.8 & -- & -- & -- & -- & - & -- & -- \\
\hline
\end{tabular}




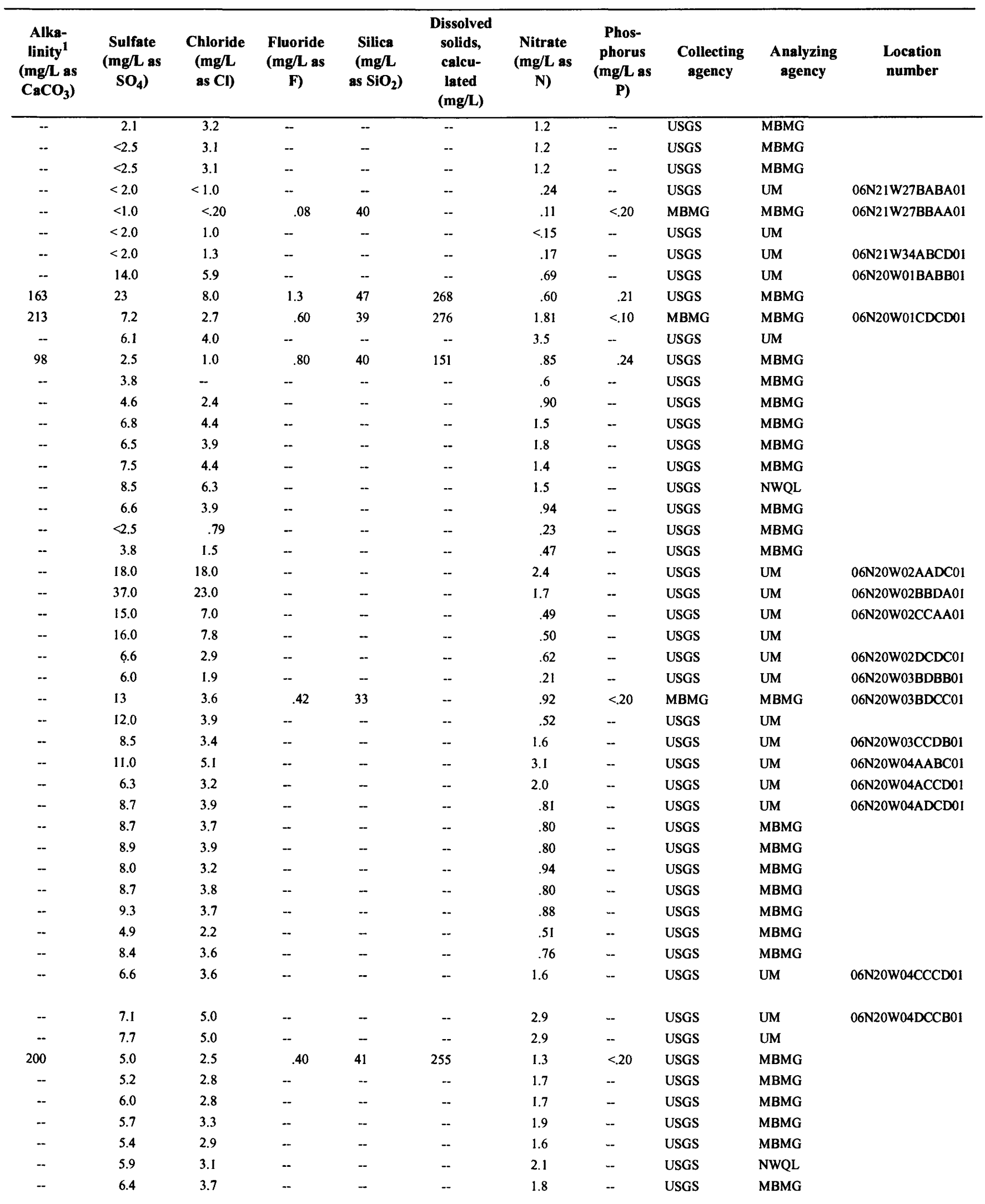

TABLE 699 
Table 6. Physical properties and major-ion concentrations for water from wells (Continued)

\begin{tabular}{|c|c|c|c|c|c|c|c|c|c|c|c|}
\hline $\begin{array}{l}\text { Location } \\
\text { number }\end{array}$ & Date & $\begin{array}{c}\text { Specific } \\
\text { conduct- } \\
\text { ance, } \\
\text { field } \\
(\mu \mathrm{S} / \mathrm{cm})\end{array}$ & $\begin{array}{c}\text { pH, } \\
\text { field } \\
\text { (stand- } \\
\text { ard } \\
\text { units) }\end{array}$ & $\begin{array}{l}\text { Temper- } \\
\text { ature, } \\
\text { water } \\
\left.\text { ( }{ }^{\circ} \mathrm{C}\right)\end{array}$ & $\begin{array}{l}\text { Oxygen, } \\
\text { dis- } \\
\text { solved, } \\
\text { field } \\
\text { (mg/L) }\end{array}$ & $\begin{array}{c}\begin{array}{c}\text { Cal- } \\
\text { cium }\end{array} \\
(\mathrm{mg} / \mathrm{L} \text { as } \\
\text { Ca })\end{array}$ & $\begin{array}{c}\text { Magne- } \\
\text { sium } \\
(\mathrm{mg} / \mathrm{L} \text { as } \\
\text { Mg) }\end{array}$ & $\begin{array}{c}\text { Sodium } \\
\text { (mg/L as } \\
\mathrm{Na})\end{array}$ & $\begin{array}{l}\text { Potas- } \\
\text { sium } \\
(\mathrm{mg} / \mathrm{L} \text { as } \\
\mathrm{K})\end{array}$ & $\begin{array}{c}\text { Bicar- } \\
\text { bonate } \\
(\mathrm{mg} / \mathrm{L} \text { as } \\
\left.\mathrm{HCO}_{3}\right)\end{array}$ & $\begin{array}{c}\text { Carbon- } \\
\text { ate }^{1} \\
(\mathrm{mg} / \mathrm{L} \text { as } \\
\left.\mathrm{CO}_{3}\right)\end{array}$ \\
\hline & $06-24-97$ & 421 & $-\cdot$ & 12.2 & -- & -- & - & - & - & -- & -- \\
\hline & $08-19-97$ & 404 & -- & 12.4 & -- & -- & -- & -- & -- & -- & -- \\
\hline & $10-15-97$ & - & -- & -- & -- & - & -- & -- & - & - & - \\
\hline 06N20W09BDDD01 & $07-27-95$ & 595 & 7.4 & 12.0 & - & -- & -- & -- & - & -- & -- \\
\hline 06N20W09CBCC01 & $08-15-95$ & 332 & 7.5 & 13.0 & -- & -- & -- & -- & - & -- & -- \\
\hline 06N20W09CCDB01 & $05-03-95$ & 375 & 7.5 & 12.5 & -- & -- & - & -- & - & -- & - \\
\hline 06N20W09DCAB01 & $06-15-95$ & 588 & 7.2 & 12.0 & -- & -- & -- & -- & - & -- & -- \\
\hline \multirow[t]{9}{*}{ 06N20W10AADC01 } & $07-14-95$ & 775 & 7.6 & 12.5 & -- & -- & -- & -- & - & - & -- \\
\hline & $09-14-95$ & 773 & 7.5 & 11.0 & 2.0 & 110 & 20 & 28 & 7.0 & 495 & 0 \\
\hline & $01-07-97$ & - & - & 9.6 & -- & -- & -- & -- & - & -- & -- \\
\hline & $02-26-97$ & 774 & - & 9.5 & - & - & -- & -- & -- & -- & -- \\
\hline & 04-03-97 & 774 & - & 10.0 & - & -- & - & - & -- & -- & -- \\
\hline & $05-20-97$ & 753 & - & 10.3 & -- & -- & -- & - & - & - & -- \\
\hline & $06-24-97$ & 747 & -- & 10.2 & -- & -- & - & -- & -- & -- & - \\
\hline & $08-19-97$ & 766 & -- & 10.8 & -- & -- & -- & -- & - & -- & -- \\
\hline & $10-14-97$ & - & - & -- & - & -- & -- & -- & - & -- & -- \\
\hline 06N20W10ABDB01 & $06-15-95$ & 419 & 8.0 & 10.0 & -- & -- & -- & -- & -- & -- & -- \\
\hline \multirow[t]{3}{*}{ 06N20W10BCAC01 } & $07-14-95$ & 429 & 7.8 & 12.0 & -- & -- & -- & -- & -- & - & -- \\
\hline & $07-14-95^{2}$ & 429 & 7.8 & 12.0 & -- & -- & -- & - & - & -- & -- \\
\hline & $09-14-95$ & 465 & 7.6 & 11.5 & 9.0 & 50 & 7.3 & 43 & 4.6 & 265 & 0 \\
\hline \multirow[t]{2}{*}{ 06N20W10CACB01 } & $06-15-95$ & 600 & 7.9 & 13.0 & -- & -- & -- & - & - & -- & - \\
\hline & $06-15-95^{2}$ & 600 & 7.9 & 13.0 & -- & -- & - & -- & - & -- & - \\
\hline 06N20W10DADD01 & $07-27-95$ & 420 & 7.7 & 13.0 & -- & -- & -- & -- & - & -- & - \\
\hline 06N20W10DBBB01 & $07-27-95$ & 411 & 7.9 & 12.0 & -- & -- & -- & - & -- & -- & -- \\
\hline 06N20W10DCAB01 & $07-27-95$ & 384 & 8.0 & 10.5 & -- & - & -- & - & - & $-\cdot$ & -- \\
\hline 06N20W11CCBD01 & $06-15-95$ & 598 & 7.8 & 12.5 & -- & -- & - & - & - & -- & - \\
\hline 06N20W11DBAA01 & $06-15-95$ & 582 & 7.5 & 11.5 & - & -- & - & -- & - & -- & - \\
\hline 06N20W12ABDB01 & $06-15-95$ & 232 & 7.8 & 11.0 & - & -. & - & -- & - & -- & -- \\
\hline \multirow[t]{11}{*}{ 06N20W12CCCD01 } & $06-15-95$ & 750 & 7.6 & 11.5 & -- & -- & -- & -- & - & - & - \\
\hline & $09-08-95$ & 618 & 7.9 & 10.5 & 5.7 & 75 & 15 & 47 & 2.3 & 385 & 0 \\
\hline & $09-08-95^{2}$ & 618 & 7.9 & 10.5 & 5.7 & 74 & 15 & 47 & 2.2 & 385 & 0 \\
\hline & $01-07-97$ & 638 & - & 10.2 & -- & -- & -- & -- & -- & -- & -- \\
\hline & $02-26-97$ & 620 & - & 10.4 & - & -- & - & -- & -- & -- & -- \\
\hline & 04-03-97 & 604 & -- & 10.7 & - & - & - & -- & - & -- & -- \\
\hline & $05-20-97$ & - & -- & -- & -- & -- & - & -- & -- & -- & -- \\
\hline & $06-24-97$ & 510 & -- & 10.7 & - & -- & - & -- & - & -- & -- \\
\hline & $08-19-97$ & 556 & -- & 10.3 & - & - & - & - & - & -- & - \\
\hline & $10-15-97$ & - & - & -- & -- & -- & -- & -- & - & -- & -- \\
\hline & $10-15-97^{2}$ & - & -- & -- & -- & -- & -- & -- & - & -- & -- \\
\hline 06N20W13BADD01 & $06-15-95$ & 864 & 7.3 & 12.0 & - & - & - & -- & - & -- & -- \\
\hline 06N20W13BCAC01 & $07-14-95$ & 637 & 7.6 & 12.5 & -- & -- & - & -- & -- & -- & -- \\
\hline \multirow[t]{2}{*}{ 06N20W14ACDD01 } & $06-15-95$ & 578 & 7.6 & 9.5 & -- & -- & -- & -- & - & - & - \\
\hline & $09-07-95$ & 581 & 7.7 & 11.5 & 7.3 & 29 & 6.1 & 100 & 3.8 & 355 & 0 \\
\hline 06N20W14BADB01 & $05-02-95$ & 440 & 7.5 & 11.0 & -- & -- & - & -- & - & -- & -- \\
\hline \multirow[t]{2}{*}{ 06N20W14BBBB01 } & $07-30-79$ & 350 & - & 18.5 & - & 68 & 12 & 21 & 4.4 & - & -- \\
\hline & 08-28-79 & 330 & -- & 13.0 & -- & 73 & 12 & 20 & 5.1 & -- & - \\
\hline 06N20W14CAAA01 & $07-14-95$ & 248 & 7.3 & 10.0 & -- & -- & -- & -- & - & -- & -- \\
\hline 06N20W14CDAB01 & 08-05-95 & 555 & 7.5 & 14.5 & - & -- & - & -- & - & -- & - \\
\hline \multirow[t]{3}{*}{ 06N20W14DAAA01 } & $08-24-95$ & 517 & 8.1 & 18.0 & -- & -- & -- & -- & -- & -- & -- \\
\hline & $08-24-95^{2}$ & 517 & 8.1 & 18.0 & -- & - & -- & -- & -- & - & -- \\
\hline & $09-07-95$ & 540 & 7.6 & 11.0 & 7.9 & 47 & 9.2 & 65 & 4.3 & 310 & 0 \\
\hline 06N20W15AACD01 & $06-15-95$ & 580 & 7.6 & 12.0 & -- & - & -- & - & -- & -- & - \\
\hline
\end{tabular}




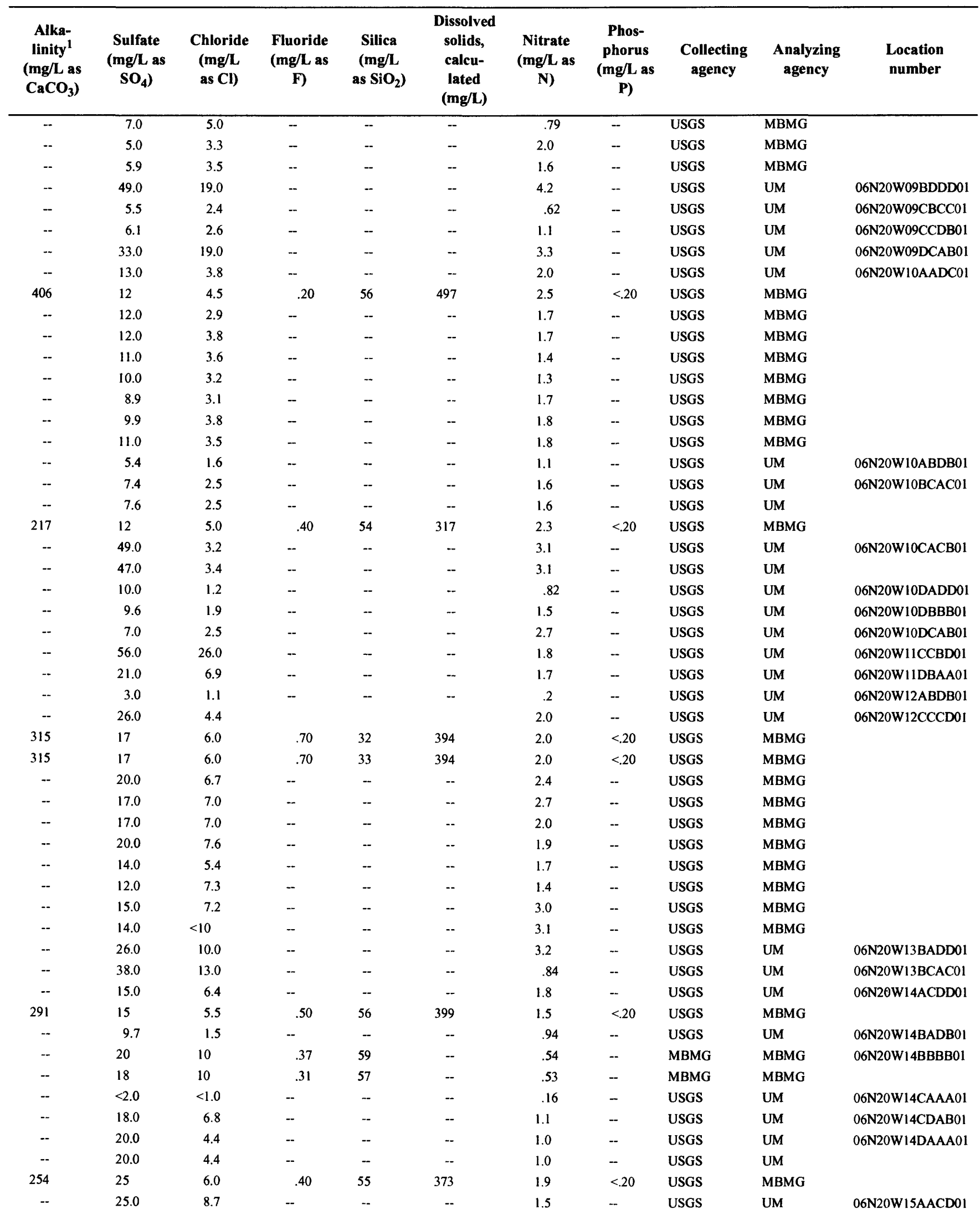

TABLE 6101 
Table 6. Physical properties and major-ion concentrations for water from wells (Continued)

\begin{tabular}{|c|c|c|c|c|c|c|c|c|c|c|c|}
\hline $\begin{array}{l}\text { Location } \\
\text { number }\end{array}$ & Date & $\begin{array}{l}\text { Specific } \\
\text { conduct- } \\
\text { ance, } \\
\text { field } \\
(\mu S / c m)\end{array}$ & $\begin{array}{l}\text { pH, } \\
\text { field } \\
\text { (stand- } \\
\text { ard } \\
\text { units) }\end{array}$ & $\begin{array}{l}\text { Temper- } \\
\text { ature, } \\
\text { water } \\
\left({ }^{\circ} \mathrm{C}\right)\end{array}$ & $\begin{array}{l}\text { Oxygen, } \\
\text { dis- } \\
\text { solved, } \\
\text { field } \\
\text { (mg/L) }\end{array}$ & $\begin{array}{c}\text { Cal- } \\
\text { cium } \\
\text { (mg/L as } \\
\text { Ca) }\end{array}$ & $\begin{array}{l}\text { Magne- } \\
\text { sium } \\
\text { (mg/L as } \\
\mathrm{Mg})\end{array}$ & $\begin{array}{c}\text { Sodium } \\
\text { (mg/L as } \\
\text { Na) }\end{array}$ & $\begin{array}{l}\text { Potas- } \\
\text { sium } \\
\text { (mg/L as } \\
\mathrm{K})\end{array}$ & $\begin{array}{c}\text { Bicar- } \\
\text { bonate }^{1} \\
(\mathrm{mg} / \mathrm{L} \text { as } \\
\left.\mathrm{HCO}_{3}\right)\end{array}$ & $\begin{array}{c}\text { Carbon- } \\
\text { ate }^{1} \\
(\mathrm{mg} / \mathrm{L} \text { as } \\
\left.\mathrm{CO}_{3}\right)\end{array}$ \\
\hline \multirow[t]{2}{*}{$06 \mathrm{~N} 20 \mathrm{~W} 15 \mathrm{BBCC01}$} & $06-15-95$ & 481 & 7.5 & 11.5 & - & -- & - & - & - & -- & -- \\
\hline & $06-15-95^{2}$ & 481 & 7.5 & 11.5 & -- & -- & -- & -- & - & -- & -- \\
\hline 06N20W15CACC01 & $07-27-95$ & 505 & 7.5 & 11.5 & -- & -- & -- & - & -- & - & - \\
\hline \multirow[t]{2}{*}{ 06N20W16AABD01 } & $08-15-95$ & 526 & 7.5 & 15.0 & -- & - & -- & -- & - & -- & - \\
\hline & $09-14-95$ & 523 & 7.3 & 11.5 & 7.0 & 71 & 13 & 22 & 3.7 & 287 & 0 \\
\hline 06N20W16ACCB01 & $05-02-95$ & 484 & 7.5 & 11.5 & -- & -- & $\cdots$ & -- & -- & $\cdots$ & -- \\
\hline \multirow[t]{2}{*}{ 06N20W16ADCB01 } & $07-27-95$ & 577 & 7.5 & 14.5 & -- & -- & -- & $\cdots$ & - & -- & -- \\
\hline & $09-07-95$ & 563 & 7.6 & 12.5 & 6.7 & 70 & 12 & 40 & 3.1 & 342 & 0 \\
\hline \multirow[t]{2}{*}{ 06N20W16BAAD01 } & $06-15-95$ & 364 & 7.5 & 10.0 & -- & -- & -- & -- & - & -- & -- \\
\hline & $09-07-95$ & 353 & 7.5 & 12.5 & 8.8 & 42 & 7.9 & 19 & 2.8 & 156 & 0 \\
\hline 06N20W16DDDB01 & $06-15-95$ & 453 & 7.5 & 9.5 & - & -- & - & -- & -- & -- & -- \\
\hline 06N20W17AACA01 & $06-15-95$ & 284 & 6.9 & 10.0 & - & -- & - & -- & - & -- & -- \\
\hline 06N20W17ADCC01 & $05-02-95$ & 307 & 7.2 & 10.5 & - & -- & - & -- & - & -- & - \\
\hline \multirow[t]{2}{*}{ 06N20W29BADB01 } & $03-09-94$ & 402 & 7.3 & 11.0 & - & 64 & 9.1 & 6.7 & 3.3 & - & -- \\
\hline & $08-24-95$ & 409 & 7.7 & 12.5 & -- & -- & - & -- & - & - & -- \\
\hline 06N19W06CBCA01 & $07-27-95$ & 739 & 6.9 & 14.5 & -- & -- & - & - & - & -- & -- \\
\hline \multirow[t]{4}{*}{ 06N19W07BABC01 } & $07-27-95$ & 391 & 7.6 & 12.0 & - & -- & - & -- & - & -- & -- \\
\hline & $07-27-95^{2}$ & 391 & 7.6 & 12.0 & - & -- & - & - & -- & - & - \\
\hline & $09-14-95$ & 429 & 7.3 & 11.5 & 7.8 & 64 & 7.6 & 17 & 3.7 & 243 & 0 \\
\hline & $09-14-95^{2}$ & 429 & 7.3 & 11.5 & 7.8 & 62 & 7.6 & 18 & 3.7 & 243 & 0 \\
\hline 05N21W03ACBA01 & $08-15-95$ & 106 & 6.3 & 9.0 & -- & -- & -- & -- & - & - & - \\
\hline 05N21W12BCAB01 & $08-15-95$ & 42.1 & 6.4 & 11.0 & - & -- & - & - & -- & -- & - \\
\hline \multirow[t]{2}{*}{ 05N21W15AABD01 } & $08-18-92$ & 172 & 8.5 & -- & .7 & 3.5 & 3.9 & 28 & 1.3 & 95 & 4 \\
\hline & $12-14-95$ & 158 & 8.0 & 11.0 & -- & -- & -- & -- & - & - & -- \\
\hline \multirow[t]{2}{*}{ 05N21W15AADB01 } & $08-18-92$ & 36.0 & 6.1 & 10.5 & 7.2 & 2.7 & .9 & 2.3 & .70 & 17 & 0 \\
\hline & $12-14-95$ & 40.3 & 6.7 & 7.5 & -- & -- & - & - & -- & -- & - \\
\hline 05N21W22CDAD01 & $08-15-95$ & 95.8 & 7.3 & 13.5 & - & - & -- & -- & - & - & - \\
\hline \multirow[t]{2}{*}{ 05N21W23BBAA01 } & 08-15-95 & 40.0 & -- & 11.5 & - & - & -- & -- & -- & -- & $\cdots$ \\
\hline & $08-15-95^{2}$ & 40.0 & - & 11.5 & -- & $\cdots$ & -- & -- & -- & -- & -- \\
\hline 05N21W27DDBD01 & $08-15-95$ & 108 & 6.6 & 11.5 & - & - & - & -- & -- & -- & -- \\
\hline \multirow[t]{3}{*}{ 05N21W36DCC 02} & $08-20-92$ & 115 & 6.2 & 9.5 & 1.4 & 7.5 & 2.0 & 11 & 1.1 & 53 & 0 \\
\hline & $06-06-96$ & 102 & 6.4 & 7.5 & -- & -- & - & - & -- & - & - \\
\hline & $06-06-96^{2}$ & 102 & 6.4 & 7.5 & -- & -- & -- & -- & -- & - & 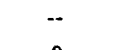 \\
\hline \multirow[t]{2}{*}{ 05N20W10BAAC01 } & $08-18-92$ & 630 & 7.7 & 10.5 & 7.5 & 45 & 13 & 78 & 3.6 & 374 & 0 \\
\hline & $12-14-95$ & 622 & 7.9 & 9.0 & - & -- & $\cdots$ & -- & - & -- & -- \\
\hline 05N20W17BADC01 & $08-15-95$ & 424 & 7.8 & 13.5 & - & -- & - & -- & - & - & $\cdots$ \\
\hline 05N20W17CBAB01 & $08-15-95$ & 427 & 4.1 & 15.0 & - & -- & -- & - & -- & -- & -- \\
\hline 05N20W17CDDB01 & $08-25-95$ & 435 & 8.0 & 11.0 & - & $-\cdot$ & - & -- & -- & -- & -- \\
\hline 05N20W18ABDA01 & $08-15-95$ & 426 & 7.6 & 14.5 & -- & -- & - & -- & -- & - & -- \\
\hline 05N20W18ADBA01 & $08-15-95$ & 415 & 7.5 & 13.5 & -- & -- & -- & - & - & -- & -- \\
\hline \multirow[t]{2}{*}{ 05N20W18CACC01 } & $08-18-92$ & 237 & 7.1 & 12.0 & 8.2 & 28 & 6.2 & 10 & 1.9 & 140 & 0 \\
\hline & $12-14-95$ & 244 & 7.2 & 10.0 & -- & -- & - & -- & -- & -- & -- \\
\hline \multirow[t]{2}{*}{ 05N20W18DACA01 } & $08-15-95$ & 310 & 7.8 & 12.5 & -- & -- & -- & -- & -- & - & -- \\
\hline & $08-15-95^{2}$ & 310 & 7.8 & 12.5 & - & -- & -- & -- & - & - & -- \\
\hline 05N20W18DBAA01 & $08-15-95$ & 288 & 7.6 & 11.5 & - & -- & - & - & - & -- & -- \\
\hline 05N20W18DCDB01 & $08-15-95$ & 243 & 7.7 & 13.0 & - & -- & -- & -- & - & -- & -- \\
\hline \multirow[t]{2}{*}{ 05N20W30BDCD01 } & $03-09-94$ & 181 & 6.9 & 9.5 & -- & 23 & 4.3 & 6.6 & 2.2 & -- & - \\
\hline & $12-14-95$ & 188 & 6.7 & 10.0 & -- & -- & -- & -- & - & $\cdots$ & - \\
\hline \multirow[t]{2}{*}{ 04N21W14CBAA01 } & $08-19-92$ & 254 & 6.6 & 11.5 & 6.9 & 33 & 7.6 & 6.8 & 3.4 & 144 & 0 \\
\hline & $12-13-95$ & 284 & 6.8 & 10.0 & - & - & - & -- & -- & - & -- \\
\hline \multirow[t]{2}{*}{ 04N21W16DDDD01 } & $08-20-92$ & 70.0 & 6.2 & 11.5 & 6.0 & 5.9 & 1.5 & 5.5 & .40 & 39 & 0 \\
\hline & $12-13-95$ & 70.4 & 6.8 & 10.0 & -- & -- & - & - & -- & -- & - \\
\hline
\end{tabular}




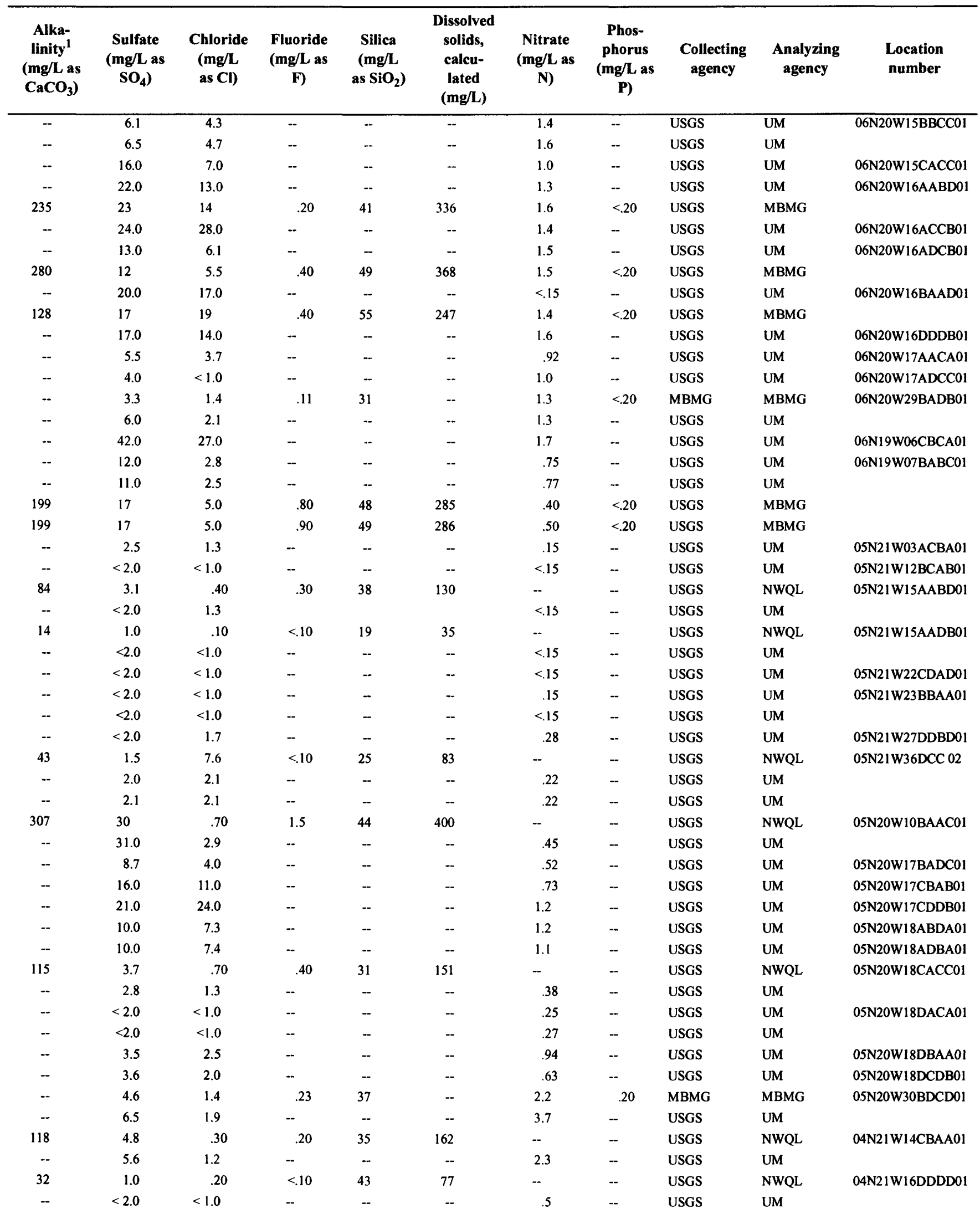


Table 6. Physical properties and major-ion concentrations for water from wells (Continued)

\begin{tabular}{|c|c|c|c|c|c|c|c|c|c|c|c|}
\hline $\begin{array}{l}\text { Location } \\
\text { number }\end{array}$ & Date & $\begin{array}{c}\text { Specific } \\
\text { conduct- } \\
\text { ance, } \\
\text { field } \\
(\mu S / c m)\end{array}$ & $\begin{array}{c}\text { pH, } \\
\text { field } \\
\text { (stand- } \\
\text { ard } \\
\text { units) }\end{array}$ & $\begin{array}{c}\text { Temper- } \\
\text { ature, } \\
\text { water } \\
\left({ }^{\circ} \mathrm{C}\right)\end{array}$ & $\begin{array}{l}\text { Oxygen, } \\
\text { dis- } \\
\text { solved, } \\
\text { field } \\
\text { (mg/L) }\end{array}$ & $\begin{array}{c}\text { Cal- } \\
\text { cium } \\
\text { (mg/L as } \\
\text { Ca) }\end{array}$ & $\begin{array}{c}\text { Magne- } \\
\text { sium } \\
\text { (mg/L as } \\
\text { Mg) }\end{array}$ & $\begin{array}{c}\text { Sodium } \\
\text { (mg/L as } \\
\mathrm{Na})\end{array}$ & $\begin{array}{c}\text { Potas- } \\
\text { sium } \\
\text { (mg/L as } \\
\mathrm{K} \text { ) }\end{array}$ & $\begin{array}{c}\text { Bicar- } \\
\text { bonate }^{1} \\
(\mathrm{mg} / \mathrm{L} \text { as } \\
\left.\mathrm{HCO}_{3}\right)\end{array}$ & $\begin{array}{c}\text { Carbon- } \\
\text { ate }^{1} \\
(\mathrm{mg} / \mathrm{L} \text { as } \\
\left.\mathrm{CO}_{3}\right)\end{array}$ \\
\hline 04N21 W35CCBA0I & $08-19-92$ & 156 & 6.7 & 10.5 & 4.8 & 16 & 5.6 & 6.5 & 1.8 & 92 & 0 \\
\hline 03N21W14BBAC01 & $08-19-92$ & 159 & 6.5 & 10.5 & 4.3 & 14 & 2.7 & 16 & 1.4 & 98 & 0 \\
\hline \multirow[t]{2}{*}{ 03N21W15CCCD01 } & $08-19-92$ & 148 & 6.5 & 9.5 & 6.0 & 15 & 3.5 & 11 & .50 & 84 & 0 \\
\hline & $06-06-96$ & 151 & 6.8 & 9.5 & - & $\cdots$ & -- & -- & - & $\cdots$ & -- \\
\hline \multirow[t]{2}{*}{ 02N21W01CACD01 } & $12-13-95$ & 215 & 7.0 & 9.5 & - & -- & - & -- & -- & -- & -- \\
\hline & $12-13-95^{2}$ & 215 & 7.0 & 9.5 & - & - & -- & -- & - & - & - \\
\hline 02N20W07BCCC01 & $08-19-92$ & 54.0 & 6.8 & 11.0 & 7.4 & 5.6 & 1.2 & 2.2 & 1.4 & 28 & 0 \\
\hline 02N20W07CABC01 & $12-13-95$ & 69.9 & 6.8 & 9.0 & -- & - & -- & - & -- & -- & - \\
\hline
\end{tabular}

TField incremental titration for samples collected by USGS. Laboratory fixed-end titration for samples collected by MBMG.

${ }^{2}$ Replicate analyses. 


\begin{tabular}{|c|c|c|c|c|c|c|c|c|c|c|}
\hline $\begin{array}{c}\text { Alka- } \\
\text { linity } \\
(\mathrm{mg} / \mathrm{L} \text { as } \\
\left.\mathrm{CaCO}_{3}\right)\end{array}$ & $\begin{array}{c}\text { Sulfate } \\
(\mathrm{mg} / \mathrm{L} \text { as } \\
\left.\mathrm{SO}_{4}\right)\end{array}$ & $\begin{array}{c}\text { Chloride } \\
\text { (mg/L } \\
\text { as } \mathrm{Cl} \text { ) }\end{array}$ & $\begin{array}{c}\text { Fluoride } \\
\text { (mg/L as } \\
\text { F) }\end{array}$ & $\begin{array}{c}\text { Silica } \\
(\mathrm{mg} / \mathrm{L} \\
\left.\text { as } \mathrm{SiO}_{2}\right)\end{array}$ & $\begin{array}{l}\text { Dissolved } \\
\text { solids, } \\
\text { calcu- } \\
\text { lated } \\
\text { (mg/L) }\end{array}$ & $\begin{array}{l}\text { Nitrate } \\
\text { (mg/L as } \\
\text { N) }\end{array}$ & $\begin{array}{c}\text { Phos- } \\
\text { phorus } \\
\text { (mg/L as } \\
\text { P) }\end{array}$ & $\begin{array}{l}\text { Collecting } \\
\text { agency }\end{array}$ & $\begin{array}{l}\text { Analyzing } \\
\text { agency }\end{array}$ & $\begin{array}{l}\text { Location } \\
\text { number }\end{array}$ \\
\hline 76 & 2.0 & .60 & .20 & 29 & 107 & - & -- & USGS & NWQL & $04 \mathrm{~N} 21 \mathrm{~W} 35 \mathrm{CCBA} 01$ \\
\hline 80 & 2.5 & .70 & .10 & 26 & 112 & - & - & USGS & NWQL & 03N21W14BBAC01 \\
\hline -- & $<2.0$ & 1.3 & -- & -. & -- & .18 & -- & USGS & UM & 02N21W01CACD01 \\
\hline-- & $<2.0$ & $<1.0$ & - & -- & -- & .16 & - & USGS & UM & \\
\hline 23 & 1.5 & .40 & .10 & 13 & 40 & -- & - & USGS & NWQL & 02N20W07BCCC01 \\
\hline -- & 2.6 & 1.0 & -- & -- & -- & .43 & -- & USGS & UM & 02N20W07CABC01 \\
\hline
\end{tabular}


Table 7. Trace-element and radon concentrations for water from wells

[Location number--numbering system described in text. Constituents are dissolved, except as indicated. Collecting agency: MBMG, Montana Bureau of Mines and Geology, Butte, Mont.; USGS, U.S. Geological Survey, Helena, Mont. Analyzing agency: MBMG, Montana Bureau of Mines and Geology, Analytical Division, Butte, Mont.; NWQL, USGS National Water Quality Laboratory, Arvada, Colo. Abbreviations: $\mu \mathrm{g} / \mathrm{L}, \mathrm{micrograms}$ per liter; pCi/L, picocuries per liter. Symbols: <, less than; --, no data]

\begin{tabular}{|c|c|c|c|c|c|c|c|c|c|c|c|c|c|}
\hline Location number & Date & $\begin{array}{c}\text { Alu- } \\
\text { min- } \\
\text { um } \\
(\mu \mathrm{g} / \mathrm{L} \\
\text { as } \\
\text { Al) }\end{array}$ & $\begin{array}{c}\text { Arse- } \\
\text { nic, } \\
\mathbf{A s}^{+3} \\
\text { and } \\
\mathbf{A s}^{+5} \\
(\mu \mathrm{g} / \mathrm{L} \text { as } \\
\text { As })\end{array}$ & $\begin{array}{c}\text { Bar- } \\
\text { ium } \\
(\mu \mathrm{g} / \mathrm{L} \text { as } \\
\text { Ba })\end{array}$ & $\begin{array}{c}\text { Beryl- } \\
\text { lium } \\
(\mu \mathrm{g} / \mathrm{L} \text { as } \\
\text { Be) }\end{array}$ & $\begin{array}{l}\text { Boron } \\
(\mu \mathrm{g} / \mathrm{L} \\
\text { as B) }\end{array}$ & $\begin{array}{c}\text { Cad- } \\
\text { mium } \\
(\mu \mathrm{g} / \mathrm{L} \\
\text { as Cd) }\end{array}$ & $\begin{array}{c}\text { Chro- } \\
\text { mium } \\
(\mu \mathrm{g} / \mathrm{L} \\
\text { as Cr) }\end{array}$ & $\begin{array}{c}\text { Cop- } \\
\text { per } \\
(\mu \mathrm{g} / \mathrm{L} \\
\text { as } \mathrm{Cu})\end{array}$ & $\begin{array}{c}\text { Iron } \\
(\mu \mathrm{g} / \mathrm{L} \\
\text { as Fe) }\end{array}$ & $\begin{array}{c}\text { Lead } \\
(\mu \mathrm{g} / \mathrm{L} \text { as } \\
\text { Pb) }\end{array}$ & $\begin{array}{l}\text { Lith- } \\
\text { ium } \\
(\mu \mathrm{g} / \mathrm{L} \\
\text { as Li) }\end{array}$ & $\begin{array}{c}\text { Man- } \\
\text { ganese } \\
(\mu \mathrm{g} / \mathrm{L} \text { as } \\
\text { Mn) }\end{array}$ \\
\hline 10N20W10ACBC01 & $06-23-80$ & - & -- & -- & - & -- & -- & $-\cdots$ & -- & $<10$ & -- & - & $<10$ \\
\hline 10N20W10CBBD01 & $03-10-94$ & $<30$ & $<1$ & 3 & $<2$ & $<30$ & $<2$ & $<2$ & 47 & 3 & $<2$ & $<6$ & $<2$ \\
\hline $10 \mathrm{~N} 20 \mathrm{~W} 11 \mathrm{CDCD} 01$ & $03-10-94$ & $<30$ & $<1$ & 71 & $<2$ & $<30$ & $<2$ & $<2$ & $<2$ & 450 & $<2$ & $<6$ & 51 \\
\hline $10 \mathrm{~N} 20 \mathrm{~W} 12 \mathrm{ADCB} 01$ & $09-13-95$ & $<30$ & $<1$ & 77 & $<2$ & $<30$ & $<2$ & $<2$ & $<2$ & 4 & $<2$ & $<6$ & $<2$ \\
\hline $10 \mathrm{~N} 20 \mathrm{~W} 12 \mathrm{DDDC} 01$ & $09-15-95$ & $<30$ & 2 & 110 & $<2$ & $<30$ & $<2$ & $<2$ & $<2$ & $<3$ & $<2$ & $<6$ & $<2$ \\
\hline 10N20W13BBA 01 & $05-12-80$ & -- & -. & -- & -. & - & - & -- & - & 160 & - & - & $<10$ \\
\hline 10N19W05DCDD01 & $09-12-95$ & $<30$ & $<1$ & 190 & $<2$ & $<80$ & $<2$ & $<2$ & $<2$ & $<3$ & $<2$ & 6 & $<2$ \\
\hline 10N19W06DCDA01 & $09-12-95$ & $<30$ & 1 & 140 & - & $<30$ & $<2$ & $<2$ & $<2$ & $<3$ & $<2$ & $<6$ & $<2$ \\
\hline 10N19W06DDCC01 & $09-19-95$ & -- & -- & -- & -- & -. & -- & -- & -- & -- & -- & - & -. \\
\hline \multirow[t]{2}{*}{ 10N19W07ADBC01 } & $09-13-95$ & $<30$ & $<1$ & 98 & $<2$ & $<80$ & $<2$ & $<2$ & $<2$ & 12 & $<2$ & $<6$ & 3 \\
\hline & $09-13-95^{1}$ & $<30$ & $<1$ & 100 & -- & $<30$ & $<2$ & $<2$ & $<2$ & 5 & $<2$ & $<6$ & $<2$ \\
\hline 10N19W07BACB01 & $09-12-95$ & $<30$ & $<1$ & 110 & $<2$ & $<30$ & $<2$ & $<2$ & $<2$ & $<3$ & $<2$ & $<6$ & $<2$ \\
\hline 10N19W07CAAB01 & $09-15-95$ & $<30$ & $<1$ & 76 & $<2$ & $<30$ & $<2$ & $<2$ & $<2$ & 4 & $<2$ & $<6$ & $<2$ \\
\hline 10N19W07CDCC01 & $09-13-95$ & $<30$ & $<1$ & 92 & $<2$ & $<30$ & $<2$ & $<2$ & $<2$ & $<3$ & $<2$ & $<6$ & $<2$ \\
\hline 10N19W08ADDC01 & $09-12-95$ & $<30$ & 4 & 130 & $<2$ & $<30$ & $<2$ & $<2$ & $<2$ & 6 & $<2$ & $<6$ & 15 \\
\hline 10N19W08BCAD01 & 09-13-95 & $<30$ & $<1$ & 100 & $<2$ & $<80$ & $<2$ & $<2$ & $<2$ & 270 & $<2$ & 23 & 32 \\
\hline 10N19W08CDAC01 & $09-13-95$ & $<30$ & $<1$ & 100 & $<2$ & $<80$ & $<2$ & $<2$ & 5 & $<3$ & $<2$ & $<6$ & $<2$ \\
\hline 10N19W08DBBD01 & $09-12-95$ & $<30$ & 5 & 140 & $<2$ & $<80$ & $<2$ & $<2$ & 3 & $<3$ & $<2$ & 7 & 4 \\
\hline 10N19W08DCCB01 & $09-13-95$ & $<30$ & $<1$ & 97 & $<2$ & $<30$ & $<2$ & $<2$ & $<2$ & $<3$ & $<2$ & $<6$ & $<2$ \\
\hline 10N19W08DCCC02 & $03-10-94$ & $<30$ & $<1$ & 100 & $<2$ & $<30$ & $<2$ & $<2$ & 32 & $<3$ & $<2$ & $<6$ & 2 \\
\hline 10N19W16BBBC01 & $09-15-95$ & $<30$ & 2 & 60 & $<2$ & $<30$ & $<2$ & $<2$ & $<2$ & 6 & $<2$ & $<6$ & $<2$ \\
\hline 10N19W18AADB01 & $09-13-95$ & $<30$ & $<1$ & 73 & $<2$ & $<30$ & $<2$ & $<2$ & $<2$ & $<3$ & $<2$ & $<6$ & $<2$ \\
\hline 10N19W18DBBA01 & $09-13-95$ & $<30$ & $<1$ & 80 & $<2$ & $<30$ & $<2$ & $<2$ & 36 & $<3$ & $<2$ & $<6$ & $<2$ \\
\hline 09N20W20CDCD01 & $09-14-95$ & $<30$ & $<1$ & 11 & $<2$ & $<30$ & $<2$ & $<2$ & $<2$ & 200 & $<2$ & $<6$ & 6 \\
\hline 08N21W27DCBC01 & $03-10-94$ & 160 & $<1$ & 21 & $<2$ & $<30$ & $<2$ & $<2$ & $<2$ & 150 & $<2$ & 11 & $<2$ \\
\hline 08N20W01DAAD01 & $08-20-92$ & -- & .- & 55 & $<.5$ & 40 & 5 & $<5$ & $<10$ & 4 & $<10$ & $<4$ & $<1$ \\
\hline $08 \mathrm{~N} 20 \mathrm{~W} 14 \mathrm{ABDB} 01$ & $09-15-95$ & $<30$ & 3 & 140 & $<2$ & $<30$ & $<2$ & $<2$ & 3 & $<3$ & $<2$ & 8 & $<2$ \\
\hline $08 \mathrm{~N} 20 \mathrm{~W} 23 \mathrm{CDDD} 01$ & $08-20-92$ & -- & -. & 40 & $<.5$ & 20 & 2 & $<5$ & $<10$ & 18 & 10 & 7 & 3 \\
\hline 08N20W26BAAC01 & $03-10-94$ & $<30$ & $<1$ & 27 & $<2$ & $<30$ & $<2$ & $<2$ & $<2$ & 12 & $<2$ & 14 & 130 \\
\hline 08N19W04BDAA01 & $03-09-94$ & $<30$ & $<1$ & 31 & $<2$ & $<30$ & $<2$ & $<2$ & $<2$ & 42 & $<2$ & $<6$ & $<2$ \\
\hline 08N19W07CBBD01 & $03-10-94$ & $<30$ & 2 & 55 & $<2$ & 220 & $<2$ & $<2$ & 2 & $<2$ & $<2$ & 7 & $<2$ \\
\hline 08N19W11CDBB01 & $08-20-92$ & -- & - & 37 & $<.5$ & 10 & 1 & $<5$ & $<10$ & 38 & $<10$ & 10 & 1 \\
\hline \multirow[t]{2}{*}{ 07N21W13BBAD01 } & $08-17-92$ & - & -. & 7 & $<.5$ & $<10$ & 1 & $<5$ & $<10$ & $<3$ & $<10$ & $<4$ & $<1$ \\
\hline & $08-17-92^{1}$ & -- & -- & 7 & $<.5$ & $<10$ & 2 & $<5$ & $<10$ & $<3$ & $<10$ & $<4$ & $<1$ \\
\hline $07 \mathrm{~N} 21 \mathrm{~W} 25 \mathrm{CABC} 01$ & $08-17-92$ & -- & -- & 23 & $<.5$ & $<10$ & 2 & $<5$ & $<10$ & 160 & $<10$ & 9 & 16 \\
\hline 07N21 W36DDDC01 & $03-09-94$ & $<30$ & $<1$ & 7 & $<2$ & $<30$ & $<2$ & $<2$ & 11 & 13 & $<2$ & 7 & $<2$ \\
\hline 07N20W32DDDA02 & $03-09-94$ & $<30$ & 3 & 64 & $<2$ & $<30$ & $<2$ & $<2$ & $<2$ & 4 & $<2$ & 10 & $<2$ \\
\hline 06N21W02ABBD01 & $03-09-94$ & $<30$ & $<1$ & 6 & $<2$ & $<30$ & $<2$ & $<2$ & 4 & 3 & $<2$ & 14 & $<2$ \\
\hline 06N21 W03DDAA01 & $09-07-95$ & 30 & $<1$ & 48 & $<2$ & $<80$ & $<2$ & 3 & 12 & 39 & $<2$ & 10 & $<2$ \\
\hline 06N21W09DADA01 & $09-07-95$ & $<30$ & $<1$ & 42 & $<2$ & 130 & $<2$ & 4 & $<2$ & $<10$ & $<2$ & 58 & 20 \\
\hline
\end{tabular}




\begin{tabular}{|c|c|c|c|c|c|c|c|c|c|c|c|c|}
\hline $\begin{array}{c}\text { Molyb- } \\
\text { denum } \\
(\mu \mathrm{g} / \mathrm{L} \text { as } \\
\text { Mo })\end{array}$ & $\begin{array}{l}\text { Nickel } \\
(\mu \mathrm{g} / \mathrm{L} \\
\text { as } \mathrm{Ni})\end{array}$ & $\begin{array}{c}\text { Sele- } \\
\text { nium } \\
(\mu \mathrm{g} / \mathrm{L} \text { as } \\
\text { Se })\end{array}$ & $\begin{array}{c}\text { Silver } \\
(\mu g / L \text { as } \\
\text { Ag) }\end{array}$ & $\begin{array}{l}\text { Stron- } \\
\text { tium } \\
(\mu \mathrm{g} / \mathrm{L} \text { as } \\
\mathrm{Sr})\end{array}$ & $\begin{array}{l}\text { Tita- } \\
\text { nium } \\
(\mu \mathrm{g} / \mathrm{L} \\
\text { as } \mathrm{Ti})\end{array}$ & $\begin{array}{l}\text { Vana- } \\
\text { dium } \\
(\mu \mathrm{g} / \mathrm{L} \\
\text { as } \mathrm{V})\end{array}$ & $\begin{array}{c}\text { Zinc } \\
(\mu \mathrm{g} / \mathrm{L} \text { as } \\
\mathrm{Zn})\end{array}$ & $\begin{array}{c}\text { Zirco- } \\
\text { nium } \\
(\mu \mathrm{g} / \mathrm{L} \text { as } \\
\mathrm{Zr})\end{array}$ & $\begin{array}{c}\text { Radon } \\
222, \text { total } \\
(\mathrm{pCi} / \mathrm{L})\end{array}$ & $\begin{array}{l}\text { Collecting } \\
\text { agency }\end{array}$ & $\begin{array}{l}\text { Analyz- } \\
\text { ing agency }\end{array}$ & Location number \\
\hline-- & - & -- & -- & -- & - & -- & -- & -- & - & MBMG & MBMG & 10N20W10ACBC01 \\
\hline$<10$ & $<2$ & $<1$ & $<1$ & 24 & $<10$ & $<5$ & 17 & $<20$ & -- & MBMG & MBMG & $10 \mathrm{~N} 20 \mathrm{~W} 10 \mathrm{CBBD} 01$ \\
\hline$<10$ & $<2$ & $<1$ & $<1$ & 120 & $<10$ & $<5$ & 61 & $<20$ & -- & MBMG & MBMG & $10 \mathrm{~N} 20 \mathrm{~W} 11 \mathrm{CDCD} 01$ \\
\hline$<10$ & $<2$ & $<1$ & $<1$ & 74 & $<10$ & $<5$ & 15 & $<20$ & 1,080 & USGS & MBMG & 10N20W12ADCB01 \\
\hline$<10$ & $<2$ & $<1$ & $<1$ & 72 & $<10$ & $<5$ & $<8$ & $<20$ & 580 & USGS & MBMG & $10 \mathrm{~N} 20 \mathrm{~W} 12 \mathrm{DDDC} 01$ \\
\hline- & -- & - & -- & -- & -- & -- & - & -- & -- & MBMG & MBMG & 10N20W13BBA 01 \\
\hline$<10$ & 2 & 2 & $<1$ & 270 & $<10$ & $<5$ & 8 & $<20$ & 1,080 & USGS & MBMG & 10N19W05DCDD01 \\
\hline$<10$ & $<2$ & $<1$ & $<1$ & 110 & $<10$ & $<5$ & 15 & $<20$ & -- & USGS & MBMG & 10N19W06DCDA01 \\
\hline -- & - & -- & -- & -- & -- & - & - & -- & 880 & USGS & MBMG & 10N19W06DDCC01 \\
\hline$<10$ & $<2$ & $<1$ & $<1$ & 73 & $<10$ & $<5$ & 120 & $<20$ & 1,070 & USGS & MBMG & 10N19W07ADBC01 \\
\hline$<10$ & $<2$ & $<1$ & $<1$ & 72 & $<10$ & $<5$ & 130 & $<20$ & - & USGS & MBMG & \\
\hline$<10$ & $<2$ & $<1$ & $<1$ & 69 & $<10$ & $<5$ & 13 & $<20$ & 500 & USGS & MBMG & 10N19W07BACB01 \\
\hline$<10$ & $<2$ & $<1$ & $<1$ & 47 & $<10$ & $<5$ & 13 & $<20$ & 760 & USGS & MBMG & 10N19W07CAAB01 \\
\hline$<10$ & $<2$ & $<1$ & $<1$ & 66 & $<10$ & $<5$ & 24 & $<20$ & 410 & USGS & MBMG & 10N19W07CDCC01 \\
\hline$<10$ & $<2$ & $<1$ & $<1$ & 110 & $<10$ & $<5$ & 430 & $<20$ & -. & USGS & MBMG & 10N19W08ADDC01 \\
\hline$<10$ & $<2$ & 1 & $<1$ & 110 & $<10$ & $<5$ & 200 & $<20$ & 710 & USGS & MBMG & 10N19W08BCAD01 \\
\hline$<10$ & $<2$ & $<1$ & $<1$ & 61 & $<10$ & $<5$ & 77 & $<20$ & 510 & USGS & MBMG & 10N19W08CDAC01 \\
\hline$<10$ & $<2$ & 2 & $<1$ & 61 & $<10$ & $<5$ & $<8$ & $<20$ & 810 & USGS & MBMG & 10N19W08DBBD01 \\
\hline$<10$ & $<2$ & $<1$ & $<1$ & 48 & $<10$ & $<5$ & 15 & $<20$ & 550 & USGS & MBMG & 10N19W08DCCB01 \\
\hline$<10$ & $<2$ & $<1$ & $<1$ & 49 & $<10$ & $<5$ & 490 & $<20$ & - & MBMG & MBMG & 10N19W08DCCC02 \\
\hline$<10$ & $<2$ & $<1$ & $<1$ & 40 & $<10$ & $<5$ & 180 & $<20$ & 650 & USGS & MBMG & 10N19W16BBBC01 \\
\hline$<10$ & $<2$ & $<1$ & $<1$ & 33 & $<10$ & $<5$ & 18 & $<20$ & 810 & USGS & MBMG & 10N19W18AADB01 \\
\hline$<10$ & $<2$ & $<1$ & $<1$ & 35 & $<10$ & $<5$ & $<8$ & $<20$ & 660 & USGS & MBMG & 10N19W18DBBA01 \\
\hline$<10$ & $<2$ & $<1$ & $<1$ & 160 & $<10$ & $<5$ & $<8$ & $<20$ & -- & USGS & MBMG & $09 \mathrm{~N} 20 \mathrm{~W} 20 \mathrm{CDCD} 01$ \\
\hline$<10$ & $<2$ & $<1$ & $<1$ & 89 & $<10$ & $<5$ & 16 & 29 & -- & MBMG & MBMG & $08 \mathrm{~N} 21 \mathrm{~W} 27 \mathrm{DCBC} 01$ \\
\hline$<10$ & $<10$ & - & $<1$ & 290 & -- & $<6$ & 180 & -. & -- & USGS & NWQL & 08N20W01 DAAD01 \\
\hline$<10$ & $<2$ & $<1$ & $<1$ & 200 & $<10$ & $<5$ & 120 & $<20$ & - & USGS & MBMG & 08N20W14ABDB01 \\
\hline$<10$ & $<10$ & - & 1 & 85 & -- & $<6$ & 120 & -- & - & USGS & NWQL & 08N20W23CDDD01 \\
\hline$<10$ & $<2$ & $<1$ & $<1$ & 180 & $<10$ & $<5$ & 18 & $<20$ & -- & MBMG & MBMG & 08N20W26BAAC01 \\
\hline$<10$ & $<2$ & $<1$ & $<1$ & 41 & $<10$ & $<5$ & 25 & $<20$ & - & MBMG & MBMG & 08N19W04BDAA01 \\
\hline$<10$ & $<2$ & $<1$ & $<1$ & 360 & $<10$ & $<5$ & 34 & $<20$ & - & MBMG & MBMG & 08N19W07CBBD01 \\
\hline$<10$ & $<10$ & - & $<1$ & 54 & -- & $<6$ & 36 & -- & - & USGS & NWQL & 08N19W11CDBB01 \\
\hline$<10$ & $<10$ & - & $<1$ & 120 & -- & $<6$ & 21 & -- & 3,600 & USGS & NWQL & 07N21 W13BBAD01 \\
\hline$<10$ & $<10$ & - & $<1$ & 120 & -- & $<6$ & 24 & -- & - & USGS & NWQL & \\
\hline$<10$ & $<10$ & -- & $<1$ & 87 & -- & $<6$ & 17 & - & 1,800 & USGS & NWQL & $07 \mathrm{~N} 21 \mathrm{~W} 25 \mathrm{CABC} 01$ \\
\hline$<10$ & $<2$ & $<1$ & $<1$ & 43 & $<10$ & $<5$ & 220 & $<20$ & - & MBMG & MBMG & 07N21W36DDDC01 \\
\hline$<10$ & $<2$ & $<1$ & $<1$ & 130 & $<10$ & $<5$ & 25 & $<20$ & - & MBMG & MBMG & 07N20W32DDDA02 \\
\hline$<10$ & $<2$ & $<1$ & $<1$ & 110 & $<10$ & $<5$ & 7 & $<20$ & -- & MBMG & MBMG & $06 \mathrm{~N} 21 \mathrm{~W} 02 \mathrm{ABBD} 01$ \\
\hline$<10$ & $<2$ & $<1$ & $<1$ & 150 & $<10$ & $<5$ & 19 & $<20$ & 1,950 & USGS & MBMG & 06N21W03DDAA01 \\
\hline$<10$ & $<2$ & $<1$ & $<1$ & 730 & $<10$ & $<5$ & 43 & $<20$ & 1,280 & USGS & MBMG & 06N21W09DADA01 \\
\hline
\end{tabular}


Table 7. Trace-element and radon concentrations for water from wells (Continued)

\begin{tabular}{|c|c|c|c|c|c|c|c|c|c|c|c|c|c|}
\hline Location number & Date & $\begin{array}{c}\text { Alu- } \\
\text { min- } \\
\text { um } \\
(\mu \mathrm{g} / \mathrm{L} \\
\text { as } \\
\mathrm{Al})\end{array}$ & $\begin{array}{c}\text { Arse- } \\
\text { nic, } \\
\mathbf{A s}^{+3} \\
\text { and } \\
\mathbf{A s}^{+5} \\
(\mu \mathrm{g} / \mathrm{L} \text { as } \\
\text { As) }\end{array}$ & $\begin{array}{c}\text { Bar- } \\
\text { ium } \\
(\mu \mathrm{g} / \mathrm{Las} \\
\mathrm{Ba})\end{array}$ & $\begin{array}{c}\text { Beryl- } \\
\text { lium } \\
(\mu \mathrm{g} / \mathrm{Las} \\
\text { Be })\end{array}$ & $\begin{array}{l}\text { Boron } \\
(\mu \mathrm{g} / \mathrm{L} \\
\text { as B) }\end{array}$ & $\begin{array}{c}\text { Cad- } \\
\text { mium } \\
(\mu \mathrm{g} / \mathrm{L} \\
\text { as } \mathrm{Cd})\end{array}$ & $\begin{array}{l}\text { Chro- } \\
\text { mium } \\
(\mu \mathrm{g} / \mathrm{L} \\
\text { as Cr })\end{array}$ & $\begin{array}{c}\text { Cop- } \\
\text { per } \\
(\mu g / L \\
\text { as } C u)\end{array}$ & $\begin{array}{c}\text { Iron } \\
(\mu g / \mathbf{L} \\
\text { as Fe) }\end{array}$ & $\begin{array}{c}\text { Lead } \\
(\mu \mathrm{g} / \mathbf{L} \text { as } \\
\text { Pb) }\end{array}$ & $\begin{array}{l}\text { Lith- } \\
\text { ium } \\
(\mu \mathrm{g} / \mathrm{L} \\
\text { as Li) }\end{array}$ & $\begin{array}{c}\text { Man- } \\
\text { ganese } \\
(\mu \mathrm{g} / \mathrm{L} \text { as } \\
\mathrm{Mn})\end{array}$ \\
\hline $06 \mathrm{~N} 21 \mathrm{~W} 11 \mathrm{ABAA01}$ & $09-06-95$ & $<30$ & $<1$ & 67 & $<2$ & $<80$ & $<2$ & $<2$ & $<2$ & 1,000 & $<2$ & $<6$ & 120 \\
\hline 06N21W11CDCB01 & $09-06-95$ & $<30$ & 1 & 57 & $<2$ & $<80$ & $<2$ & $<2$ & $<2$ & 1,400 & $<2$ & 25 & 39 \\
\hline 06N21W12BDDD01 & $09-06-95$ & 60 & $<1$ & 53 & $<2$ & $<80$ & $<2$ & $<2$ & $<2$ & 1,200 & $<2$ & 6 & 54 \\
\hline \multirow[t]{2}{*}{ 06N21W14BDAC01 } & 09-06-95 & 40 & $<1$ & 6 & $<2$ & $<80$ & $<2$ & $<2$ & $<2$ & 15 & $<2$ & 8 & $<2$ \\
\hline & $09-06-95^{1}$ & 40 & $<1$ & 6 & $<2$ & $<80$ & $<2$ & $<2$ & $<2$ & 16 & $<2$ & $<6$ & $<2$ \\
\hline $06 \mathrm{~N} 21 \mathrm{~W} 15 \mathrm{CDDD} 01$ & $08-17-92$ & -- & -- & 3 & $<.5$ & $<10$ & $<1$ & $<5$ & $<10$ & 6 & $<10$ & $<4$ & $<1$ \\
\hline 06N21W22AADC01 & $09-06-95$ & 60 & $<1$ & 7 & $<2$ & $<80$ & $<2$ & $<2$ & 4 & 170 & $<2$ & 9 & 3 \\
\hline 06N21W23CABC01 & $09-06-95$ & $<30$ & $<1$ & 12 & $<2$ & $<80$ & $<2$ & $<2$ & 7 & $<10$ & $<2$ & 11 & $<2$ \\
\hline 06N21W23DDAD01 & $09-05-95$ & 190 & $<1$ & 10 & $<2$ & $<80$ & $<2$ & $<2$ & 4 & 300 & $<2$ & 12 & 6 \\
\hline 06N21W23DDBB01 & 09-05-95 & 190 & $<1$ & 13 & $<2$ & $<80$ & $<2$ & $<2$ & 2 & 280 & $<2$ & 12 & 6 \\
\hline 06N21W24BAAC01 & $09-06-95$ & $<30$ & $<1$ & 14 & $<2$ & $<80$ & $<2$ & $<2$ & $<2$ & 250 & $<2$ & 9 & 6 \\
\hline $06 \mathrm{~N} 21 \mathrm{~W} 24 \mathrm{CCAC} 01$ & $09-05-95$ & 160 & $<1$ & 6 & $<2$ & $<80$ & $<2$ & $<2$ & 6 & 230 & $<2$ & 6 & 4 \\
\hline 06N21W25DBAA01 & $08-18-92$ & -- & -- & 32 & $<.5$ & $<10$ & 3 & $<5$ & $<10$ & $<3$ & $<10$ & $<4$ & $<1$ \\
\hline 06N21W26DBAD01 & $03-08-94$ & $<30$ & $<1$ & 17 & $<2$ & $<30$ & $<2$ & $<2$ & $<2$ & 91 & $<2$ & 12 & 10 \\
\hline 06N21 W27BBAA01 & $03-08-94$ & $<30$ & $<1$ & 10 & $<2$ & $<30$ & $<2$ & $<2$ & $<2$ & 45 & $<2$ & 9 & 8 \\
\hline $06 \mathrm{~N} 20 \mathrm{~W} 01 \mathrm{BABB} 01$ & 09-14-95 & $<30$ & 12 & 24 & $<2$ & 120 & $<2$ & $<2$ & $<2$ & 5 & $<2$ & 14 & $<2$ \\
\hline $06 \mathrm{~N} 20 \mathrm{~W} 01 \mathrm{CDCD} 01$ & $09-07-95$ & $<30$ & 11 & 35 & $<2$ & $<80$ & $<2$ & 8 & 4 & 11 & $<2$ & 10 & $<2$ \\
\hline 06N20W03BDCC01 & $03-09-94$ & $<30$ & 4 & 55 & $<2$ & $<30$ & $<2$ & $<2$ & 3 & 4 & $<2$ & 10 & $<2$ \\
\hline 06N20W04DCCB01 & $09-14-95$ & $<80$ & 8 & 64 & - & $<80$ & $<2$ & $<2$ & $<2$ & 8 & $<2$ & 9 & $<2$ \\
\hline 06N20W10AADC01 & $09-14-95$ & $<30$ & 9 & 180 & $<2$ & 80 & $<2$ & 6 & 2 & 4 & $<2$ & 12 & $<2$ \\
\hline $06 \mathrm{~N} 20 \mathrm{~W} 10 \mathrm{BCAC01}$ & $09-14-95$ & $<30$ & 7 & 120 & $<2$ & 90 & $<2$ & $<2$ & $<2$ & $<3$ & $<2$ & 7 & $<2$ \\
\hline \multirow[t]{2}{*}{ 06N20W12CCCD01 } & $09-08-95$ & $<30$ & 9 & 79 & $<2$ & 80 & $<2$ & 8 & $<2$ & $<5$ & $<2$ & 10 & $<2$ \\
\hline & $09-08-95^{1}$ & $<30$ & 9 & 78 & $<2$ & $<80$ & $<2$ & 7 & $<2$ & $<5$ & $<2$ & $<10$ & $<2$ \\
\hline 06N20W14ACDD01 & $09-07-95$ & $<30$ & 11 & 79 & $<2$ & 200 & $<2$ & 7 & $<2$ & 6 & $<2$ & 21 & $<2$ \\
\hline \multirow[t]{2}{*}{ 06N20W14BBBB01 } & $07-30-79$ & -- & -- & -- & -- & -- & -- & -- & -- & 30 & -- & 10 & $<10$ \\
\hline & $08-28-79$ & -- & -- & -- & -- & -- & -- & -- & -- & $<0$ & - & 9 & $<0$ \\
\hline 06N20W14DAAA01 & $09-07-95$ & $<30$ & 8 & 64 & $<2$ & 170 & $<2$ & 6 & $<2$ & $<5$ & $<2$ & 13 & $<2$ \\
\hline 06N20W16AABD01 & $09-14-95$ & $<30$ & 2 & 95 & $<2$ & $<30$ & $<2$ & $<2$ & $<2$ & $<3$ & $<2$ & $<6$ & $<2$ \\
\hline 06N20W16ADCB01 & $09-07-95$ & $<30$ & 4 & 120 & $<2$ & 80 & $<2$ & 7 & 7 & $<3$ & $<2$ & 12 & $<2$ \\
\hline 06N20W16BAAD01 & $09-07-95$ & $<30$ & 5 & 69 & $<2$ & $<80$ & $<2$ & 4 & 4 & $<10$ & $<2$ & 10 & $<2$ \\
\hline 06N20W29BADB01 & $03-09-94$ & $<30$ & 2 & 83 & $<2$ & $<30$ & $<2$ & $<2$ & $<2$ & $<2$ & $<2$ & $<6$ & $<2$ \\
\hline $06 \mathrm{~N} 20 \mathrm{~W} 30 \mathrm{DBCC} 01$ & $09-19-92$ & -- & -- & - & -- & - & - & - & - & -- & - & -- & - \\
\hline \multirow[t]{2}{*}{ 06N19W07BABC01 } & $09-14-95$ & $<30$ & 5 & 71 & $<2$ & 80 & $<2$ & $<2$ & $<2$ & 5 & $<2$ & 9 & $<2$ \\
\hline & $09-14-95^{1}$ & $<30$ & 5 & 71 & $<2$ & 90 & $<2$ & $<2$ & $<2$ & 6 & $<2$ & 11 & $<2$ \\
\hline 05N21W15AABD01 & $08-18-92$ & - & -- & 9 & $<.5$ & 10 & 3 & $<5$ & $<10$ & 45 & $<10$ & 28 & 290 \\
\hline 05N21W15AADB01 & $08-18-92$ & -- & -- & 3 & $<.5$ & $\dot{<10}$ & 3 & $<5$ & $<10$ & 39 & $<10$ & $<4$ & 20 \\
\hline 05N21W36DCC 02 & $08-20-92$ & -- & -- & 22 & $<.5$ & $<10$ & 1 & $<5$ & $<10$ & 1,200 & $<10$ & 8 & 76 \\
\hline $05 \mathrm{~N} 20 \mathrm{~W} 10 \mathrm{BAAC} 01$ & $08-18-92$ & -- & -- & 42 & $<.5$ & $<10$ & $<1$ & $<5$ & $<10$ & $<3$ & $<10$ & 12 & $<1$ \\
\hline $05 \mathrm{~N} 20 \mathrm{~W} 18 \mathrm{CACC} 01$ & $08-18-92$ & -- & -- & 54 & $<.5$ & $<10$ & 2 & $<5$ & $<10$ & 40 & 20 & 6 & 14 \\
\hline 05N20W30BDCD01 & $03-09-94$ & $<30$ & $<1$ & 29 & $<2$ & $<30$ & $<2$ & $<2$ & 5 & 4 & $<2$ & 18 & $<2$ \\
\hline 04N21W14CBAA01 & $08-19-92$ & -- & -- & 46 & $<.5$ & 10 & 2 & $<5$ & $<10$ & $<3$ & $<10$ & 13 & 1 \\
\hline 04N21 W16DDDD01 & $08-20-92$ & - & - & 11 & $<.5$ & $<10$ & 2 & $<5$ & $<10$ & 4 & $<10$ & 9 & $<1$ \\
\hline 04N21W35CCBA01 & $08-19-92$ & -- & -- & 44 & $<.5$ & 100 & 2 & $<5$ & $<10$ & 4 & $<10$ & 12 & $<1$ \\
\hline \multirow[t]{2}{*}{ 03N21W14BBAC01 } & $08-19-92$ & - & -- & 13 & $<.5$ & 10 & 3 & $<5$ & $<10$ & $<3$ & $<10$ & 17 & $<1$ \\
\hline & 09-19-92 & -- & -- & - & -- & - & -- & - & - & -- & - & - & - \\
\hline $03 \mathrm{~N} 21 \mathrm{~W} 14 \mathrm{CAAA} 01$ & $09-19-92$ & -- & -- & -- & - & -- & - & -. & -- & -- & -- & - & -- \\
\hline 03N21W15CCCD01 & 08-19-92 & -- & -- & 9 & $<.5$ & $<10$ & 3 & $<5$ & $<10$ & 5 & $<10$ & 9 & 2 \\
\hline 02N20W07BCCC01 & $08-19-92$ & - & -- & 6 & $<.5$ & $<10$ & 2 & $<5$ & $<10$ & 29 & $<10$ & $<4$ & 23 \\
\hline
\end{tabular}




\begin{tabular}{|c|c|c|c|c|c|c|c|c|c|c|c|c|}
\hline $\begin{array}{c}\text { Molyb- } \\
\text { denum } \\
(\mu \mathrm{g} / \mathrm{L} \text { as } \\
\text { Mo })\end{array}$ & $\begin{array}{l}\text { Nickel } \\
(\mu \mathrm{g} / \mathrm{L} \\
\text { as } \mathrm{Ni})\end{array}$ & $\begin{array}{c}\text { Sele- } \\
\text { nium } \\
(\mu \mathrm{g} / \mathrm{L} \text { as } \\
\text { Se) }\end{array}$ & $\begin{array}{c}\text { Silver } \\
(\mu \mathrm{g} / \mathrm{L} \text { as } \\
\mathrm{Ag})\end{array}$ & $\begin{array}{c}\text { Stron- } \\
\text { tium } \\
(\mu \mathrm{g} / \mathrm{L} \text { as } \\
\mathrm{Sr})\end{array}$ & $\begin{array}{l}\text { Tita- } \\
\text { nium } \\
(\mu \mathrm{g} / \mathrm{L} \\
\text { as Ti) }\end{array}$ & $\begin{array}{l}\text { Vana- } \\
\text { dium } \\
(\mu \mathrm{g} / \mathrm{L} \\
\text { as V) }\end{array}$ & $\begin{array}{c}\text { Zinc } \\
(\mu \mathrm{g} / \mathrm{L} \text { as } \\
\mathrm{Zn})\end{array}$ & $\begin{array}{c}\text { Zirco- } \\
\text { nium } \\
(\mu \mathrm{g} / \mathrm{L} \text { as } \\
\mathrm{Zr})\end{array}$ & $\begin{array}{l}\text { Radon } \\
\text { 222, total } \\
\text { (pCi/L) }\end{array}$ & $\begin{array}{c}\text { Collecting } \\
\text { agency }\end{array}$ & $\begin{array}{l}\text { Analyz- } \\
\text { ing agency }\end{array}$ & Location number \\
\hline$<10$ & $<2$ & $<1$ & $<1$ & 120 & $<10$ & $<5$ & 28 & $<20$ & -- & USGS & MBMG & 06N2IW11ABAA01 \\
\hline$<10$ & $<2$ & $<1$ & $<1$ & 130 & $<10$ & $<5$ & 69 & $<20$ & -- & USGS & MBMG & $06 \mathrm{~N} 2 \mathrm{IW} 11 \mathrm{CDCB} 0 \mathrm{I}$ \\
\hline$<10$ & $<2$ & $<1$ & $<1$ & 170 & $<10$ & $<5$ & 6 & $<20$ & -- & USGS & MBMG & $06 \mathrm{~N} 2$ IWI2BDDD01 \\
\hline$<10$ & $<2$ & $<1$ & $<1$ & 85 & $<10$ & $<5$ & 8 & $<20$ & -- & USGS & MBMG & $06 \mathrm{~N} 2$ I WI4BDAC0I \\
\hline$<10$ &, 2 & $<1$ & $<1$ & 84 & $<10$ & $<5$ & 8 & $<20$ & - & USGS & MBMG & \\
\hline$<10$ & $<10$ & -- & 1 & 54 & -- & $<6$ & 27 & -- & 1,600 & USGS & NWQL & 06N21WI5CDDD01 \\
\hline$<10$ & $<2$ & $<1$ & $<1$ & 45 & 20 & $<5$ & 32 & $<20$ & 1,100 & USGS & MBMG & 06N21W22AADC01 \\
\hline$<10$ & $<2$ & $<1$ & $<1$ & 84 & $<10$ & $<5$ & $<2$ & $<20$ & 1,120 & USGS & MBMG & $06 \mathrm{~N} 21 \mathrm{~W} 23 \mathrm{CABC} 01$ \\
\hline$<10$ & $<2$ & $<1$ & $<1$ & 64 & 20 & $<5$ & 3 & $<20$ & 1,130 & USGS & MBMG & 06N21W23DDAD01 \\
\hline$<10$ & $<2$ & $<1$ & $<1$ & 68 & 20 & $<5$ & 18 & $<20$ & 910 & USGS & MBMG & 06N21W23DDBB01 \\
\hline$<10$ & $<2$ & $<1$ & $<1$ & 120 & $<10$ & $<5$ & 3 & $<20$ & 2,720 & USGS & MBMG & 06N21W24BAAC01 \\
\hline$<10$ & $<2$ & $<1$ & $<1$ & 74 & 20 & $<5$ & 9 & $<20$ & 1,090 & USGS & MBMG & 06N21W24CCAC01 \\
\hline$<10$ & $<10$ & - & $<1$ & 55 & - & $<6$ & 7 & -- & 1,300 & USGS & NWQL & 06N21W25DBAA01 \\
\hline$<10$ & $<2$ & $<1$ & $<1$ & 140 & $<10$ & $<5$ & 17 & $<20$ & -- & MBMG & MBMG & $06 \mathrm{~N} 21 \mathrm{~W} 26 \mathrm{DBAD} 01$ \\
\hline$<10$ & $<2$ & $<1$ & $<1$ & 170 & $<10$ & $<5$ & 6 & $<20$ & -- & MBMG & MBMG & 06N21W27BBAA01 \\
\hline$<10$ & $<2$ & 1 & $<1$ & 120 & $<10$ & 15 & 110 & $<20$ & 490 & USGS & MBMG & 06N20W01BABB01 \\
\hline$<10$ & $<2$ & $<1$ & $<1$ & 140 & $<10$ & 28 & 42 & $<20$ & 350 & USGS & MBMG & 06N20W01CDCD01 \\
\hline$<10$ & 2 & $<1$ & $<1$ & 100 & $<10$ & $<5$ & 12 & $<20$ & - & MBMG & MBMG & 06N20W03BDCC0I \\
\hline$<10$ & $<2$ & $<1$ & $<1$ & 26 & $<10$ & 14 & 26 & $<20$ & 640 & USGS & MBMG & 06N20W04DCCB01 \\
\hline$<10$ & 3 & 1 & $<1$ & 260 & $<10$ & 7 & 91 & $<20$ & 150 & USGS & MBMG & 06N20W10AADC01 \\
\hline$<10$ & $<2$ & $<1$ & $<1$ & 120 & $<10$ & $<5$ & 32 & $<20$ & - & USGS & MBMG & $06 \mathrm{~N} 20 \mathrm{~W} 10 \mathrm{BCAC} 01$ \\
\hline$<10$ & 2 & $<1$ & $<1$ & 140 & $<10$ & 15 & 26 & $<20$ & 200 & USGS & MBMG & 06N20W12CCCD01 \\
\hline$<10$ & 2 & $<1$ & $<1$ & 140 & $<10$ & 14 & 27 & $<20$ & - & USGS & MBMG & \\
\hline 11 & $<2$ & $<1$ & $<1$ & 69 & $<10$ & 17 & 43 & $<20$ & -- & USGS & MBMG & 06N20W14ACDD01 \\
\hline-- & -- & -- & - & - & - & -- & - & -- & -- & MBMG & MBMG & 06N20W14BBBB01 \\
\hline -- & -. & -- & -- & -- & -- & -- & -- & -- & -- & MBMG & MBMG & \\
\hline 12 & $<2$ & $<1$ & $<1$ & 83 & $<10$ & 14 & 2 & $<20$ & 170 & USGS & MBMG & 06N20W14DAAA01 \\
\hline$<10$ & $<2$ & $<1$ & $<1$ & 180 & $<10$ & $<5$ & $<8$ & $<20$ & - & USGS & MBMG & 06N20W16AABD01 \\
\hline$<10$ & $<2$ & $<1$ & $<1$ & 170 & $<10$ & 9 & 23 & $<20$ & 150 & USGS & MBMG & 06N20W16ADCB01 \\
\hline$<10$ & $<2$ & 1 & $<1$ & 82 & $<10$ & 9 & 74 & $<20$ & 230 & USGS & MBMG & 06N20WI6BAAD01 \\
\hline$<10$ & 2 & $<1$ & $<1$ & 110 & $<10$ & $<5$ & 13 & $<20$ & -- & MBMG & MBMG & 06N20W29BADB0I \\
\hline-- & - & -- & -- & -- & -- & -- & - & -- & 725 & MBMG & MBMG & 06N20W30DBCC01 \\
\hline$<10$ & $<2$ & $<1$ & $<1$ & 130 & $<10$ & $<5$ & 80 & $<20$ & - & USGS & MBMG & 06NI9W07BABC01 \\
\hline$<10$ & $<2$ & $<1$ & $<1$ & 130 & $<10$ & $<5$ & 83 & $<20$ & -- & USGS & MBMG & \\
\hline$<10$ & $<10$ & - & $<1$ & 120 & - & $<6$ & $<3$ & - & -- & USGS & NWQL & 05N21W15AABD01 \\
\hline$<10$ & $<10$ & -. & 1 & 49 & -- & $<6$ & 280 & - & 670 & USGS & NWQL & 05N21W15AADB01 \\
\hline$<10$ & $<10$ & - & $<1$ & 90 & -- & $<6$ & 24 & -- & -- & USGS & NWQL & 05N21W36DCC 02 \\
\hline$<10$ & $<10$ & -- & $<1$ & 140 & - & 14 & 16 & -- & 430 & USGS & NWQL & 05N20W10BAAC01 \\
\hline$<10$ & $<10$ & -- & $<1$ & 160 & -- & 7 & 16 & -- & 1,400 & USGS & NWQL & $05 \mathrm{~N} 20 \mathrm{~W} 18 \mathrm{CACC} 01$ \\
\hline$<10$ & $<2$ & $<1$ & $<1$ & 210 & $<10$ & $<5$ & 7 & $<20$ & - & MBMG & MBMG & 05N20W30BDCD01 \\
\hline$<10$ & $<10$ & -- & $<1$ & 210 & -- & 7 & 80 & -. & -- & USGS & NWQL & 04N21W14CBAA01 \\
\hline$<10$ & $<10$ & -- & 2 & 76 & -- & $<6$ & 8 & -- & -- & USGS & NWQL & 04N21W16DDDD01 \\
\hline$<10$ & $<10$ & - & $<1$ & 180 & - & $<6$ & 34 & -- & - & USGS & NWQL & 04N21W35CCBA01 \\
\hline$<10$ & $<10$ & - & $<1$ & 160 & - & $<6$ & 4 & -- & 3,700 & USGS & NWQL & 03N21W14BBAC0I \\
\hline- & -- & -- & - & -- & -- & -- & -- & -- & 1,667 & MBMG & MBMG & \\
\hline- & -- & - & $\cdots$ & -- & -- & - & -- & -- & 2,423 & MBMG & MBMG & 03N21W14CAAA01 \\
\hline$<10$ & $<10$ & -- & $<1$ & 150 & -- & $<6$ & 14 & -- & 3,300 & USGS & NWQL & 03N21W15CCCD01 \\
\hline$<10$ & $<10$ & - & $<1$ & 46 & - & $<6$ & 530 & -- & - & USGS & NWQL & 02N20W07BCCC01 \\
\hline
\end{tabular}


Table 8. Physical properties and major-ion concentrations for water from surface-water sites and one spring

[Location number: numbering system described in text. Constituents are dissolved, except as indicated. Collecting agency: USGS, U.S. Geological Survey, Helena, Mont. Analyzing agency: MBMG, Montana Bureau of Mines and Geology, Analytical Division, Butte, Mont.; UM, University of Montana,

Missoula, Mont. Abbreviations: $\mu \mathrm{S} / \mathrm{cm}$, microsiemens per centimeter at $25^{\circ} \mathrm{C}$; ${ }^{\circ} \mathrm{C}$, degrees Celsius; $\mathrm{mg} / \mathrm{L}$, milligrams per liter. Symbols: <, less than; --, no data]

\begin{tabular}{|c|c|c|c|c|c|c|c|c|c|c|}
\hline Location number & Date & $\begin{array}{l}\text { Specific } \\
\text { conduct- } \\
\text { ance, } \\
\text { field } \\
(\mu \mathrm{S} / \mathrm{cm})\end{array}$ & $\begin{array}{c}\text { pH, } \\
\text { field } \\
\text { (stand- } \\
\text { ard } \\
\text { units) }\end{array}$ & $\begin{array}{c}\text { Temper- } \\
\text { ature, } \\
\text { water } \\
\left({ }^{\circ} \mathrm{C}\right)\end{array}$ & $\begin{array}{c}\text { Calcium } \\
\text { (mg/L as } \\
\text { Ca) }\end{array}$ & $\begin{array}{l}\text { Magne- } \\
\text { sium } \\
\text { (mg/L as } \\
\text { Mg) }\end{array}$ & $\begin{array}{c}\text { Sodium } \\
\text { (mg/L as } \\
\mathrm{Na})\end{array}$ & $\begin{array}{l}\text { Potas- } \\
\text { sium } \\
\text { (mg/L as } \\
\mathrm{K})\end{array}$ & $\begin{array}{c}\text { Bicar- } \\
\text { bonate } \\
\text { (mg/L as } \\
\left.\mathrm{HCO}_{3}\right)\end{array}$ & $\begin{array}{c}\text { Carbon- } \\
\text { ate }^{1} \\
(\mathrm{mg} / \mathrm{L} \text { as } \\
\left.\mathrm{CO}_{3}\right)\end{array}$ \\
\hline 06N21W20AABB01 & $09-20-95$ & 11 & 6.1 & 8.5 & 1.4 & 0.1 & 0.8 & 0.20 & 6 & 0 \\
\hline 06N20W12AACD01 & $09-20-95$ & 34 & 7.1 & 14.0 & 3.7 & .9 & 1.2 & .3 & 17 & 0 \\
\hline 06N20W12AACD02 & $09-20-95$ & 309 & 7.0 & 9.0 & 52 & 6.8 & 5.3 & 2.8 & 154 & 0 \\
\hline 08N20W02ACBD01 ${ }^{2}$ & $10-26-95$ & 588 & 7.4 & 9.5 & - & - & -- & - & - & - \\
\hline 10N19W03DCCD01 & $09-20-95$ & 157 & 7.7 & 8.0 & 20 & 6.4 & 3.2 & 1.5 & 94 & 0 \\
\hline
\end{tabular}

\begin{tabular}{|c|c|c|c|c|c|c|c|c|c|c|}
\hline $\begin{array}{c}\text { Alka- } \\
\text { linity } \\
\text { (mg/L as } \\
\left.\mathrm{CaCO}_{3}\right)\end{array}$ & $\begin{array}{c}\text { Sulfate } \\
(\mathrm{mg} / \mathrm{L} \text { as } \\
\left.\mathrm{SO}_{4}\right)\end{array}$ & $\begin{array}{c}\text { Chloride } \\
\text { (mg/L } \\
\text { as Cl) }\end{array}$ & $\begin{array}{c}\text { Fluoride } \\
\text { (mg/L as } \\
\text { F) }\end{array}$ & $\begin{array}{c}\text { Silica } \\
(\mathrm{mg} / \mathrm{L} \\
\left.\text { as } \mathrm{SiO}_{2}\right)\end{array}$ & $\begin{array}{c}\text { Dis- } \\
\text { solved } \\
\text { solids, } \\
\text { calcu- } \\
\text { lated } \\
\text { (mg/L) }\end{array}$ & $\begin{array}{c}\text { Nitrate } \\
\text { (mg/L as } \\
\mathrm{N})\end{array}$ & $\begin{array}{c}\text { Phos- } \\
\text { phorus } \\
\text { (mg/L as } \\
\text { P) }\end{array}$ & $\begin{array}{c}\text { Collecting } \\
\text { agency }\end{array}$ & $\begin{array}{l}\text { Analyzing } \\
\text { agency }\end{array}$ & Location number \\
\hline 5 & $<2.5$ & $<0.50$ & $<0.10$ & 5.3 & - & $<0.05$ & $<0.20$ & USGS & MBMG & 06N21W20AABB01 \\
\hline 14 & $<2.5$ & .50 & $<.10$ & 5.5 & - & $<.05$ & $<.20$ & USGS & MBMG & 06N20W12AACD01 \\
\hline 77 & 5.0 & .50 & $<.10$ & 17 & 100 & .05 & $<.20$ & USGS & MBMG & 10N19W03DCCD01 \\
\hline
\end{tabular}


Table 9. Trace-element concentrations for water from surface-water sites

[Location number: Numbering system described in text. Constituents are dissolved, except as indicated. Collecting agency: USGS, U.S. Geological Survey, Helena, Mont. Analyzing agency: MBMG, Montana Bureau of Mines and Geology, Analytical Division, Butte, Mont. Abbreviations: $\mu \mathrm{g} / \mathrm{L}$, micrograms per liter. Symbols: <, less than]

\begin{tabular}{|c|c|c|c|c|c|c|c|c|c|c|c|c|}
\hline Location number & Date & $\begin{array}{c}\text { Alu- } \\
\text { minum } \\
\text { ( } \mu \text { g/L as } \\
\text { Al) }\end{array}$ & $\begin{array}{c}\text { Arsenic, } \\
\mathbf{A s}^{+3} \text { and } \\
\mathrm{As}^{+5} \\
(\mu \mathrm{g} / \mathrm{L} \text { as } \\
\mathrm{As})\end{array}$ & $\begin{array}{c}\text { Barium } \\
\text { ( } \mu \mathrm{g} / \mathrm{Las} \\
\mathrm{Ba})\end{array}$ & $\begin{array}{l}\text { Boron } \\
\text { ( } \mu g / L \\
\text { as B) }\end{array}$ & $\begin{array}{c}\text { Cad- } \\
\text { mium } \\
(\mu g / L \\
\text { as Cd) }\end{array}$ & $\begin{array}{l}\text { Chro- } \\
\text { mium } \\
(\mu g / L \\
\text { as Cr) }\end{array}$ & $\begin{array}{c}\text { Copper } \\
(\mu \mathrm{g} / \mathrm{L} \text { as } \\
\mathrm{Cu})\end{array}$ & $\begin{array}{c}\text { Iron } \\
\text { ( } \mathrm{gg} / \mathrm{Las} \\
\text { Fe) }\end{array}$ & $\begin{array}{c}\text { Lead } \\
\text { ( } \mu \mathrm{g} / \mathrm{L} \text { as } \\
\text { Pb) }\end{array}$ & $\begin{array}{l}\text { Lith- } \\
\text { ium } \\
\text { ( } \mu \mathrm{g} / \mathrm{L} \\
\text { as Li) }\end{array}$ & $\begin{array}{c}\text { Man- } \\
\text { ganese } \\
\text { ( } \mathrm{gg} / \mathbf{L} \text { as } \\
\text { Mn) }\end{array}$ \\
\hline 06N21W20AABB01 & $09-20-95$ & 30 & $<1$ & 4 & $<30$ & $<2$ & $<2$ & $<2$ & $<20$ & $<2$ & $<6$ & $<2$ \\
\hline 06N20W12AACD01 & $09-20-95$ & $<30$ & $<1$ & 14 & $<30$ & $<2$ & $<2$ & $<2$ & $<20$ & $<2$ & $<6$ & $<2$ \\
\hline 06N20W12AACD02 & $09-20-95$ & $<30$ & 4 & 35 & $<30$ & $<2$ & $<2$ & $<2$ & $<20$ & $<2$ & $<6$ & $<2$ \\
\hline 10N19W03DCCD01 & $09-20-95$ & $<30$ & $<1$ & 53 & $<30$ & $<2$ & $<2$ & $<2$ & $<20$ & $<2$ & $<6$ & $<2$ \\
\hline
\end{tabular}

\begin{tabular}{|c|c|c|c|c|c|c|c|c|c|c|c|}
\hline $\begin{array}{l}\text { Molyb- } \\
\text { denum } \\
(\mu \mathrm{g} / \mathrm{L} \text { as } \\
\text { Mo) }\end{array}$ & $\begin{array}{c}\text { Nickel } \\
\text { ( } \mu \mathrm{g} / \mathrm{L} \text { as } \\
\text { Ni) }\end{array}$ & $\begin{array}{c}\text { Sele- } \\
\text { nium } \\
(\mu \mathrm{g} / \mathrm{L} \text { as } \\
\text { Se) }\end{array}$ & $\begin{array}{c}\text { Silver } \\
(\mu \mathrm{g} / \mathrm{L} \text { as } \\
\text { Ag) }\end{array}$ & $\begin{array}{c}\text { Stron- } \\
\text { tium } \\
\text { ( } \mu \text { g/L as } \\
\text { Sr) }\end{array}$ & $\begin{array}{c}\text { Tita- } \\
\text { nium } \\
(\mu \mathrm{g} / \mathrm{L} \text { as } \\
\text { Ti) }\end{array}$ & $\begin{array}{c}\text { Vana- } \\
\text { dium } \\
(\mu \mathrm{g} / \mathrm{L} \text { as } \\
\mathrm{V})\end{array}$ & $\begin{array}{c}\text { Zinc } \\
(\mu \mathrm{g} / \mathbf{L} \text { as } \\
\text { Zn })\end{array}$ & $\begin{array}{c}\text { Zirco- } \\
\text { nium } \\
(\mu \mathrm{g} / \mathrm{L} \text { as } \\
\mathrm{Zr})\end{array}$ & $\begin{array}{c}\text { Collecting } \\
\text { agency }\end{array}$ & $\begin{array}{c}\text { Analyzing } \\
\text { agency }\end{array}$ & Location number \\
\hline$<10$ & $<2$ & $<1$ & $<1$ & 15 & $<10$ & $<5$ & $<8$ & $<20$ & USGS & MBMG & 06N21 W20AABB01 \\
\hline$<10$ & $<2$ & $<1$ & $<1$ & 27 & $<10$ & $<5$ & $<8$ & $<20$ & USGS & MBMG & 06N20W12AACD01 \\
\hline$<10$ & $<2$ & $<1$ & $<1$ & 100 & $<10$ & $<5$ & $<8$ & $<20$ & USGS & MBMG & 06N20W12AACD02 \\
\hline$<10$ & $<2$ & $<1$ & $<1$ & 28 & $<10$ & $<5$ & $<8$ & $<20$ & USGS & MBMG & 10N19W03DCCD01 \\
\hline
\end{tabular}


Table 10. Physical properties and major-ion concentrations for deionized-water field blanks

[Location number indicates site where sampling equipment was used prior to collecting field blank. Constituents are dissolved, except as indicated. Collecting agency: USGS, U.S. Geological Survey, Helena, Mont. Analyzing agency: MBMG, Montana Bureau of Mines and Geology, Analytical Division, Butte, Mont. Abbreviations: $\mu \mathrm{S} / \mathrm{cm}$, microsiemens per centimeter at $25^{\circ} \mathrm{C} ;{ }^{\circ} \mathrm{C}$, degrees Celsius; $\mathrm{mg} / \mathrm{L}$, milligrams per liter. Symbols: <, less than; --, no data]

\begin{tabular}{|c|c|c|c|c|c|c|c|c|c|c|c|}
\hline $\begin{array}{l}\text { Location number } \\
\text { of previous site }\end{array}$ & Date & $\begin{array}{c}\text { Specific } \\
\text { conduct- } \\
\text { ance, } \\
\text { field } \\
(\mu S / c m)\end{array}$ & $\begin{array}{c}\text { pH, } \\
\text { field } \\
\text { (stand- } \\
\text { ard } \\
\text { units) }\end{array}$ & $\begin{array}{l}\text { Temper- } \\
\text { ature, } \\
\text { water } \\
\left({ }^{\circ} \mathrm{C}\right)\end{array}$ & $\begin{array}{c}\text { Oxygen, } \\
\text { dissolved, } \\
\text { field } \\
(\mathrm{mg} / \mathrm{L})\end{array}$ & $\begin{array}{c}\text { Cal- } \\
\text { cium } \\
\text { (mg/Las } \\
\text { Ca) }\end{array}$ & $\begin{array}{l}\text { Magne- } \\
\text { sium } \\
\text { (mg/L as } \\
\text { Mg) }\end{array}$ & $\begin{array}{l}\text { Sodium } \\
\text { (mg/L as } \\
\text { Na) }\end{array}$ & $\begin{array}{l}\text { Potas- } \\
\text { sium } \\
\text { (mg/L as } \\
\text { K) }\end{array}$ & $\begin{array}{c}\text { Bicar- } \\
\text { bonate }^{1} \\
(\mathrm{mg} / \mathrm{L} \text { as } \\
\left.\mathrm{HCO}_{3}\right)\end{array}$ & $\begin{array}{c}\text { Carbon- } \\
\text { ate }^{1} \\
(\mathrm{mg} / \mathrm{L} \text { as } \\
\left.\mathrm{CO}_{3}\right)\end{array}$ \\
\hline 06N20W12CCCD01 & $09-08-95$ & -- & $\cdots$ & - & 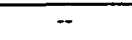 & $<0.1$ & $<0.1$ & $<0.1$ & 0.19 & - & - \\
\hline 10N20W12DDDC01 & $09-15-95$ & -- & -- & -- & -- & $<.1$ & $<.1$ & $<.1$ & $<.1$ & - & - \\
\hline
\end{tabular}

\begin{tabular}{|c|c|c|c|c|c|c|c|c|c|c|}
\hline $\begin{array}{c}\text { Alka- } \\
\text { linity } \\
\left(\mathrm{mg}^{1} \mathrm{~L} \text { as }\right. \\
\left.\mathrm{CaCO}_{3}\right)\end{array}$ & $\begin{array}{c}\text { Sulfate } \\
\text { (mg/L as } \\
\left.\mathrm{SO}_{4}\right)\end{array}$ & $\begin{array}{c}\text { Chloride } \\
\text { (mg/L } \\
\text { as Cl) }\end{array}$ & $\begin{array}{c}\text { Fluoride } \\
\text { (mg/L as } \\
\text { F) }\end{array}$ & $\begin{array}{c}\text { Silica } \\
(\mathrm{mg} / \mathrm{L} \\
\left.\text { as } \mathrm{SiO}_{2}\right)\end{array}$ & $\begin{array}{c}\text { Dis- } \\
\text { solved } \\
\text { solids, } \\
\text { calcu- } \\
\text { lated } \\
(\mathrm{mg} / \mathrm{L})\end{array}$ & $\begin{array}{c}\text { Nitrate } \\
\text { (mg/L as } \\
\mathrm{N} \text { ) }\end{array}$ & $\begin{array}{c}\text { Phos- } \\
\text { phorus } \\
\text { (mg/L as } \\
\text { P) }\end{array}$ & $\begin{array}{l}\text { Collecting } \\
\text { agency }\end{array}$ & $\begin{array}{c}\text { Analyzing } \\
\text { agency }\end{array}$ & $\begin{array}{l}\text { Location number of } \\
\text { previous site }\end{array}$ \\
\hline- & $<2.5$ & $<0.50$ & $<0.10$ & 20 & -- & $<0.05$ & $<0.20$ & USGS & MBMG & 06N20W12CCCD01 \\
\hline - & $<2.5$ & $<.50$ & $<.10$ & 20 & -- & $<.5$ & $<.20$ & USGS & MBMG & $10 \mathrm{~N} 20 \mathrm{~W} 12 \mathrm{DDDC} 01$ \\
\hline
\end{tabular}


Table 11. Trace-element concentrations for deionized-water field blanks

[Location number indicates site where sampling equipment was used prior to collecting field blank. Constituents are dissolved, except as indicated. Collecting agency: USGS, U.S. Geological Survey, Helena, Mont. Analyzing agency: MBMG, Montana Bureau of Mines and Geology, Analytical Division, Butte, Mont. Abbreviation: $\mu \mathrm{g} / \mathrm{L}$, micrograms per liter. Symbol: <, less than]

\begin{tabular}{|c|c|c|c|c|c|c|c|c|c|c|c|c|}
\hline $\begin{array}{l}\text { Location number of } \\
\text { previous site }\end{array}$ & Date & $\begin{array}{c}\text { Alu- } \\
\text { minum } \\
(\mu \mathrm{g} / \mathrm{Las} \\
\text { Al) }\end{array}$ & $\begin{array}{c}\text { Arsenic, } \\
\mathrm{As}^{+3} \text { and } \\
\mathrm{As}^{+5} \\
(\mu \mathrm{g} / \mathrm{L} \text { as } \\
\mathrm{As})\end{array}$ & $\begin{array}{c}\text { Bar- } \\
\text { ium } \\
(\mu \mathrm{g} / \mathrm{Las} \\
\text { Ba })\end{array}$ & $\begin{array}{c}\text { Beryl- } \\
\text { lium } \\
(\mu \mathrm{g} / \mathrm{L} \text { as } \\
\text { Be) }\end{array}$ & $\begin{array}{l}\text { Boron } \\
(\mu \mathrm{g} / \mathbf{L} \\
\text { as B) }\end{array}$ & $\begin{array}{c}\text { Cad- } \\
\text { mium } \\
(\mu \mathrm{g} / \mathrm{L} \\
\text { as Cd) }\end{array}$ & $\begin{array}{l}\text { Chro- } \\
\text { mium } \\
(\mu \mathrm{g} / \mathrm{L} \\
\text { as } \mathrm{Cr})\end{array}$ & $\begin{array}{c}\text { Cop- } \\
\text { per } \\
(\mu \mathrm{g} / \mathrm{Las} \\
\mathrm{Cu})\end{array}$ & 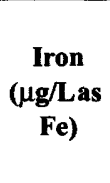 & $\begin{array}{c}\text { Lead } \\
\text { ( } \mu \mathrm{g} / \mathrm{L} \text { as } \\
\text { Pb) }\end{array}$ & $\begin{array}{l}\text { Lith- } \\
\text { ium } \\
(\mu \mathrm{g} / \mathrm{L} \\
\text { as } \mathrm{Li})\end{array}$ \\
\hline 06N20W12CCCD01 & $09-08-95$ & $<30$ & $<1$ & $<10$ & $<2$ & $<80$ & $<2$ & $<2$ & $<2$ & $<10$ & $<2$ & $<6$ \\
\hline 10N20W12DDDC01 & $09-15-95$ & $<30$ & $<1$ & 6 & $<2$ & $<30$ & $<2$ & $<2$ & $<2$ & $<3$ & $<2$ & $<6$ \\
\hline
\end{tabular}

\begin{tabular}{|c|c|c|c|c|c|c|c|c|c|c|c|c|}
\hline $\begin{array}{c}\text { Man- } \\
\text { ganese } \\
(\mu \mathrm{g} / \mathrm{L} \\
\text { as Mn) }\end{array}$ & $\begin{array}{c}\text { Molyb- } \\
\text { denum } \\
(\mu \mathrm{g} / \mathrm{L} \text { as } \\
\text { Mo })\end{array}$ & $\begin{array}{l}\text { Nickel } \\
(\mu \mathrm{g} / \mathrm{L} \\
\text { as Ni) }\end{array}$ & $\begin{array}{c}\text { Silver } \\
\text { ( } \mu \text { g/L as } \\
\text { Ag) }\end{array}$ & $\begin{array}{c}\text { Sele- } \\
\text { nium } \\
(\mu \mathrm{g} / \mathrm{L} \text { as } \\
\text { Se) }\end{array}$ & $\begin{array}{c}\text { Stron- } \\
\text { tium } \\
(\mu \mathrm{g} / \mathrm{L} \text { as } \\
\mathrm{Sr})\end{array}$ & $\begin{array}{l}\text { Tita- } \\
\text { nium } \\
(\mu \mathrm{g} / \mathrm{L} \\
\text { as Ti) }\end{array}$ & $\begin{array}{l}\text { Vana- } \\
\text { dium } \\
(\mu g / L \\
\text { as } V)\end{array}$ & $\begin{array}{c}\text { Zinc } \\
(\mu \mathrm{g} / \mathbf{L} \text { as } \\
\text { Zn) }\end{array}$ & $\begin{array}{c}\text { Zirco- } \\
\text { nium } \\
(\mu \mathrm{g} / \mathrm{L} \text { as } \\
\mathrm{Zr})\end{array}$ & $\begin{array}{c}\text { Collecting } \\
\text { agency }\end{array}$ & $\begin{array}{c}\text { Analzing } \\
\text { agency }\end{array}$ & $\begin{array}{l}\text { Location number } \\
\text { of previous site }\end{array}$ \\
\hline$<2$ & $<10$ & $<2$ & $<1$ & $<1$ & $<6$ & $<10$ & $<5$ & $<2$ & $<20$ & USGS & MBMG & 06N20W12CCCD01 \\
\hline$<2$ & $<10$ & $<2$ & $<1$ & $<1$ & $<6$ & $<10$ & $<5$ & $<8$ & $<20$ & USGS & MBMG & 10N20W12DDDC01 \\
\hline
\end{tabular}


Table 12. Drinking-water regulations and guidelines for public water supply ${ }^{1,2}$

[MCL, Maximum Contaminant Level; SMCL, Secondary Maximum Contaminant Level; mg/L, milligrams per liter; $\mu \mathrm{g} / \mathrm{L}$, micrograms per liter; --, no regulation available or not applicable]

\begin{tabular}{|c|c|c|c|c|}
\hline \multirow[b]{2}{*}{$\begin{array}{l}\text { Water-quality } \\
\text { characteristic }\end{array}$} & \multicolumn{4}{|c|}{ Maximum concentration or value for indicated regulation } \\
\hline & $\begin{array}{l}\text { National Primary } \\
\text { Drinking-Water } \\
\text { Regulation }^{3} \\
\text { (MCL) }\end{array}$ & $\begin{array}{l}\text { National Secondary } \\
\text { Drinking-Water } \\
\text { Regulation } \\
\text { (SMCL) }\end{array}$ & $\begin{array}{l}\text { Montana } \\
\text { drinking-water } \\
\text { regulation }\end{array}$ & $\begin{array}{c}\text { Equivalent } \\
\text { trace-element } \\
\text { concentration } \\
\text { for MCL or SMCL } \\
(\mu \mathrm{g} / \mathrm{L})\end{array}$ \\
\hline \multicolumn{5}{|c|}{ Phvsical property (standard units) } \\
\hline $\mathrm{pH}$ & -- & $6.5-8.5$ & -- & - \\
\hline \multicolumn{5}{|c|}{ Common constituents (mg/L) } \\
\hline Dissolved solids & -- & 500 & - & -- \\
\hline Chloride & -- & 250 & - & - \\
\hline Fluoride & 4.0 & 2.0 & 4.0 & -- \\
\hline Nitrate (as N) & 10 & -- & 10 & -- \\
\hline Sulfate & 500 & 250 & -- & -- \\
\hline \multicolumn{5}{|c|}{ Trace elements $(\mathrm{mg} / \mathrm{h})$} \\
\hline Aluminum & -- & $.05-.2$ & -- & $50-200$ \\
\hline Arsenic & .05 & -- & .018 & 50 \\
\hline Barium & 2.0 & -- & 1.0 & 2,000 \\
\hline Beryllium & .004 & -- & .04 & 4 \\
\hline Cadmium & .005 & -- & .005 & 5 \\
\hline Chromium & .1 & -- & .1 & 100 \\
\hline Copper $^{6}$ & 1.3 & 1.0 & 1.0 & 1,$300 ; 1,000$ \\
\hline Iron & -- & .3 & .3 & 300 \\
\hline Lead $^{7}$ & .015 & -- & .015 & 15 \\
\hline Manganese & -- & .05 & .05 & 50 \\
\hline Nickel & .14 & -- & .1 & 140 \\
\hline Selenium & .05 & -- & .05 & 50 \\
\hline Silver & -- & .1 & - & 100 \\
\hline Zinc & -- & 5.0 & 5.0 & 5,000 \\
\hline
\end{tabular}

${ }^{1}$ Regulations in effect as of October 1996.

${ }^{2}$ Listed only for properties, common constituents, trace elements, and radionuclides analyzed in this report.

${ }^{3}$ U.S. Environmental Protection Agency, 1996.

${ }^{4}$ Montana Department of Environmental Quality, 1995.

${ }^{5}$ The U.S. Geological Survey reports trace-element concentrations in micrograms per liter.

${ }^{6}$ Copper is covered under primary regulations by an "action level."

${ }^{7}$ Lead is covered under primary regulations by an "action level." 